\title{
\#USGS
}

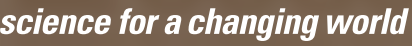

\section{Weather and Aeolian Sand-Transport Data from the Colorado River Corridor, Grand Canyon, Arizona}

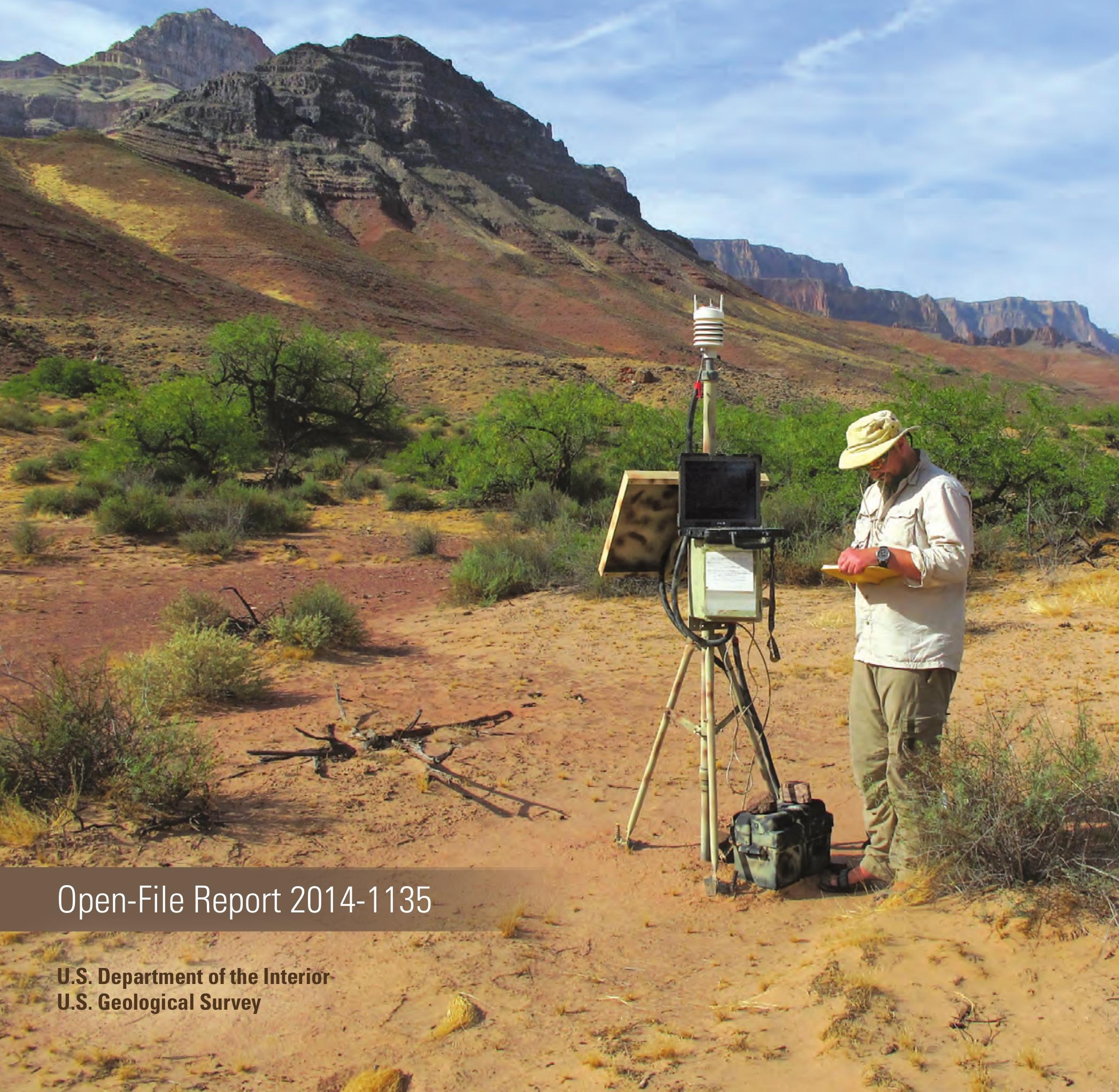


Cover: Photograph showing USGS employee Joshua Caster downloading weather data in Grand Canyon, Arizona, May 2014. Photograph by Helen Fairley. 


\section{Weather and Aeolian Sand-Transport Data from the Colorado River Corridor, Grand Canyon, Arizona}

By Timothy P. Dealy, Amy E. East, and Helen C. Fairley

Open-File Report 2014-1135

U.S. Department of the Interior

U.S. Geological Survey 


\section{U.S. Department of the Interior \\ SALLY JEWELL, Secretary}

\section{U.S. Geological Survey \\ Suzette Kimball, Acting Director}

U.S. Geological Survey, Reston, Virginia: 2014

For more information on the USGS—-the Federal source for science about the Earth, its natural and living resources, natural hazards, and the environment-visit

http://www.usgs.gov or call 1-888-ASK-USGS

For an overview of USGS information products, including maps, imagery, and publications, visit $h$ ttp://www.usgs.gov/pubprod

To order this and other USGS information products, visit http://store.usgs.gov

Suggested citation:

Dealy, T.P., East, A.E., and Fairley, H.C., 2014, 2010 weather and aeolian sand-transport data from the Colorado River corridor, Grand Canyon, Arizona: U.S. Geological Survey Open-File Report 2014-1135, 90 p., http://dx.doi.org/10.3133/ofr20141135/.

ISSN 2331-1258 (online)

Any use of trade, product, or firm names is for descriptive purposes only and does not imply endorsement by the U.S. Government.

Although this report is in the public domain, permission must be secured from the individual copyright owners to reproduce any copyrighted material contained within this report. 


\section{Contents}

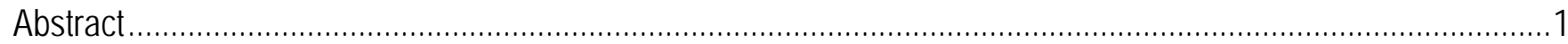

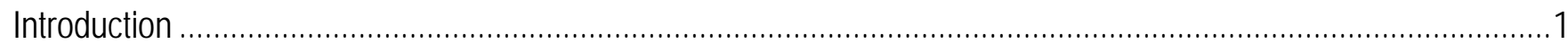

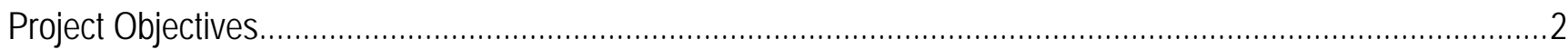

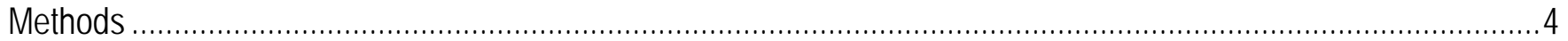

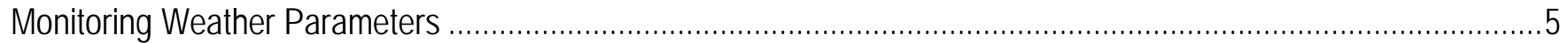

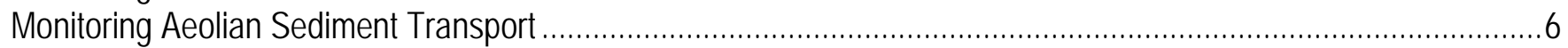

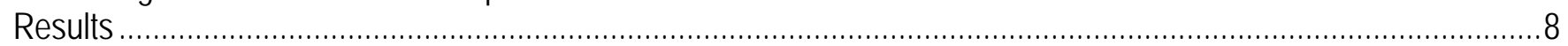

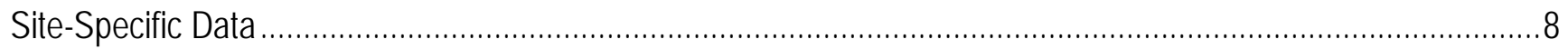

Site AZ C:05:0031

Site AZ C:13:0365

Site AZ C:13:0006

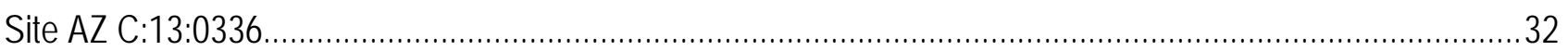

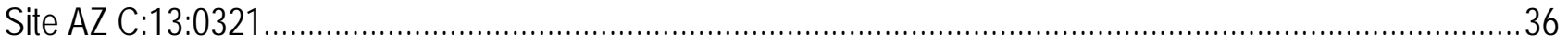

Site AZ C:13:0346

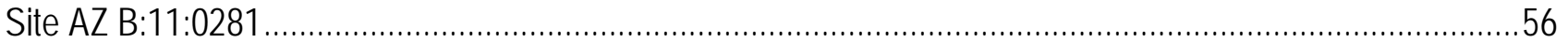

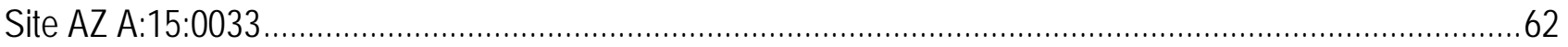

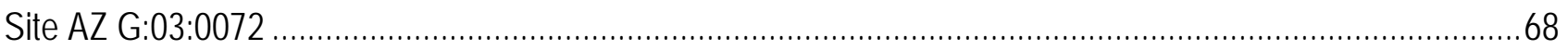

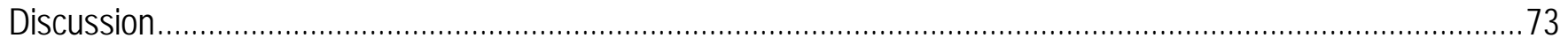

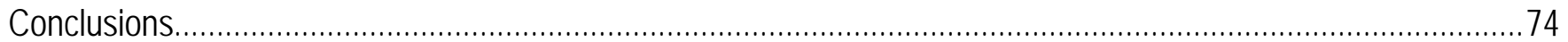

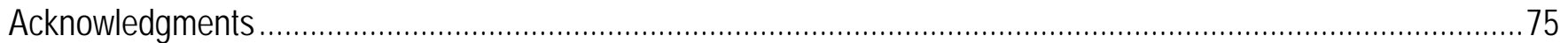

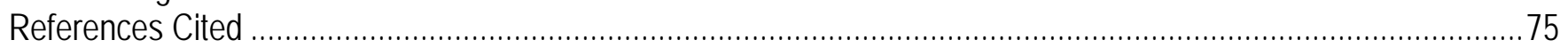

\section{Figures}

Figure 1. Map showing locations of study sites in Colorado River corridor through Grand Canyon, Arizona. ...........2

Figure 2. Photograph of instrument station near AZ C:05:0031 L in Grand Canyon, Arizona. .................................

Figure 3. Aerial photograph of the area around site AZ C:05:0031 in Grand Canyon, Arizona ................................9

Figure 4. Plot showing magnitude and direction of wind velocity measured at the instrument station

AZ C:05:0031 L with 4-minute resolution in Grand Canyon, Arizona, 2010 ..................................................10

Figure 5. Plot showing cumulative rainfall recorded at station AZ C:05:0031 L compiled from data collected at 4-minute resolution in Grand Canyon, Arizona, 2010 .............................................................................12

Figure 6. Plots showing wind, aeolian sand-transport, and rainfall data collected at the instrument station AZ C:05:0031 L in Grand Canyon, Arizona, 2009-10 ..........................................................................13

Figure 7. Plots showing temperature, relative humidity, and barometric pressure data collected at instrument station AZ C:05:0031 L in Grand Canyon, Arizona, 2009-10 ......................................................................14

Figure 8. Aerial photograph showing area around site AZ C:05:0031 in Grand Canyon, Arizona ..........................15

Figure 9. Plot showing magnitude and direction of wind velocity measured at the instrument station AZ C:05:0031 U with 4-minute resolution in Grand Canyon, Arizona, 2010 ....................................................16

Figure 10. Plot showing cumulative rainfall recorded at station AZ C:05:0031 U compiled from data collected at 4-minute resolution in Grand Canyon, Arizona, 2010.....

Figure 11. Plots showing wind, aeolian sand-transport, and rainfall data collected at the instrument station AZ C:05:0031 U in Grand Canyon, Arizona, 2009-10.

Figure 12. Plots showing temperature, relative humidity, and barometric pressure data collected at instrument station AZ C:05:0031 U in Grand Canyon, Arizona, 2009-10

Figure 13. Aerial photograph showing area around site AZ C:13:0365 in Grand Canyon, Arizona .........................21

Figure 14. Plot showing magnitude and direction of wind velocity measured at the instrument station AZ C:13:0365 L with 4-minute resolution in Grand Canyon, Arizona, 2010 
Figure 15. Plot showing cumulative rainfall recorded at station $A Z C: 13: 0365 \mathrm{~L}$ compiled from data collected at 4-minute resolution in Grand Canyon, Arizona, 2010.

Figure 16. Plots showing wind, aeolian sand-transport, and rainfall data collected at the instrument station AZ C:13:0365 L, in Grand Canyon, Arizona, 2009-10

Figure 17. Plots showing temperature, relative humidity, and barometric pressure data collected at instrument station AZ C:13:0365 L, in Grand Canyon, Arizona, 2009-10..................................................................25

Figure 18. Aerial photograph of the area around site AZ C:13:0365 in Grand Canyon, Arizona ...........................26

Figure 19. Plot showing magnitude and direction of wind velocity measured at the instrument station

AZ C:13:0365 U with 4-minute resolution in Grand Canyon, Arizona, 2010 ...................................................27

Figure 20. Plot showing cumulative rainfall recorded at station AZ C:13:0365 U compiled from data collected at 4-minute resolution in Grand Canyon, Arizona, 2010. .28

Figure 21. Plots showing wind, aeolian sand-transport, and rainfall data collected at the instrument station AZ C:13:0365 U in Grand Canyon, Arizona, 2009-10...

Figure 22. Plots showing temperature, relative humidity, and barometric pressure data collected at instrument station AZ C:13:0365 U in Grand Canyon, Arizona, 2009-10 .30

Figure 23. Aerial photograph of the area around site AZ C:13:0006 in Grand Canyon, Arizona ...........................32

Figure 24. Plot showing magnitude and direction of wind velocity measured at the instrument station

AZ C:13:0006 with 4-minute resolution in Grand Canyon, Arizona, 2010

Figure 25. Plot showing cumulative rainfall recorded at site AZ C:13:0006 compiled from data collected at 4-minute resolution in Grand Canyon, Arizona, 2010

Figure 26. Plots showing wind, aeolian sand-transport, and rainfall data collected at the instrument station AZ C:13:0006 in Grand Canyon, Arizona, 2009-10

Figure 27. Plots showing temperature, relative humidity, and barometric pressure data collected at instrument station AZ C:13:0006 in Grand Canyon, Arizona, 2009-10.

Figure 28. Aerial photograph of the area around site AZ C:13:0336 in Grand Canyon, Arizona 38

Figure 29. Plot showing magnitude and direction of wind velocity measured at the instrument station AZ C:13:0336 U with 4-minute resolution in Grand Canyon, Arizona, 2010.

Figure 30. Plot showing cumulative rainfall recorded at station AZ C:13:0336 U compiled from data collected at 4-minute resolution in Grand Canyon, Arizona, 2010.

Figure 31. Plots showing wind, aeolian sand-transport, and rainfall data collected at the instrument station AZ C:13:0336 U in Grand Canyon, Arizona, 2009-10.....

Figure 32. Plots showing temperature, relative humidity, and barometric pressure data collected at instrument station AZ C:13:0336 U in Grand Canyon, Arizona, 2009-10

Figure 33. Plots showing aeolian sand-transport data collected near AZ C:13:0321 in Grand Canyon, Arizona, 2010.

Figure 34. Aerial photograph of the area around site AZ C:13:0346 in Grand Canyon, Arizona44

Figure 35. Plot showing magnitude and direction of wind velocity measured at the instrument station

AZ C:13:0346 L with 4-minute resolution in Grand Canyon, Arizona, 2010

Figure 36. Plot showing cumulative rainfall recorded at station AZ C:13:0346 L compiled from data collected at 4-minute resolution in Grand Canyon, Arizona, 2010.

Figure 37. Plots showing wind, aeolian sand-transport, and rainfall data collected at the instrument station AZ C:13:0346 L, in Grand Canyon, Arizona, 2009-10.

Figure 38. Plots showing temperature, relative humidity, and barometric pressure data collected at instrument station AZ C:13:0346 L in Grand Canyon, Arizona, 2009-10.

Figure 39. Aerial photograph of the area around site AZ C:13:0346 in Grand Canyon, Arizona 
Figure 40. Plot showing magnitude and direction of wind velocity measured at the instrument station

AZ C:13:0346 U with 4-minute resolution in Grand Canyon, Arizona, 2010

Figure 41. Plot showing cumulative rainfall recorded at station AZ C:13:0346 U compiled from data collected at 4-minute resolution in Grand Canyon, Arizona, 2010.

Figure 42. Plots showing wind, aeolian sand-transport, and rainfall data collected at the instrument station AZ C:13:0346 U in Grand Canyon, Arizona, 2009-10......

Figure 43. Plots showing temperature, relative humidity, and barometric pressure data collected at instrument station AZ C:13:0346 U in Grand Canyon, Arizona, 2009-10

Figure 44. Aerial photograph of the area around site AZ B:11:0281 in Grand Canyon, Arizona

Figure 45. Plot showing magnitude and direction of wind velocity measured at the instrument station AZ B:11:0281 with 4-minute resolution in Grand Canyon, Arizona, 2010......

Figure 46. Plot showing cumulative rainfall recorded at site AZ B:11:0281 compiled from data collected at 4-minute resolution in Grand Canyon, Arizona, 2010.

Figure 47. Plots showing wind, aeolian sand-transport, and rainfall data collected at the instrument station AZ B:11:0281, in Grand Canyon, Arizona, 2009-10.

Figure 48. Plots showing temperature, relative humidity, and barometric pressure data collected at instrument station AZ B:11:0281 in Grand Canyon, Arizona, 2009-10.

Figure 49. Aerial photograph of the area around site AZ A:15:0033 in Grand Canyon, Arizona

Figure 50. Plot showing magnitude and direction of wind velocity measured at the instrument station AZ A:15:0033 with 4-minute resolution in Grand Canyon, Arizona, 2010.

Figure 51. Plot showing cumulative rainfall recorded at site AZ A:15:0033 compiled from data collected at 4-minute resolution in Grand Canyon, Arizona, 2010.

Figure 52. Plots showing wind, aeolian sand-transport, and rainfall data collected at the instrument station AZ A:15:0033 in Grand Canyon, Arizona, 2009-10

Figure 53. Plots showing temperature, relative humidity, and barometric pressure data collected at instrument station AZ A:15:0033 in Grand Canyon, Arizona, 2009-10.....

Figure 54. Aerial photograph of the area around site AZ G:03:0072 in Grand Canyon, Arizona

Figure 55. Plot showing magnitude and direction of wind velocity measured at the instrument station AZ G:03:0072 with 4-minute resolution in Grand Canyon, Arizona, 2010

Figure 56. Plot showing cumulative rainfall recorded at site AZ G:03:0072 compiled from data collected at 4-minute resolution in Grand Canyon, Arizona, 2010.

Figure 57. Plots showing wind, aeolian sand-transport, and rainfall data collected at the instrument station AZ G:03:0072 in Grand Canyon, Arizona, 2009-10.

Figure 58. Plots showing temperature, relative humidity, and barometric pressure data collected at instrument station AZ G:03:0072 in Grand Canyon, Arizona, 2009-10

\section{Tables}

Table 1. Station names, approximate river miles, equipment deployed at each study site, date at which each station was established, and type of aeolian setting at each study site, Colorado River corridor, Grand Canyon, Arizona....

Table 2. Total rainfall, in millimeters, recorded daily by each weather station .78

Table 3. Vector sums of the sediment-transport proxy variable, $Q p$ (equation 1), by month for each weather station, 2010. 


\section{Conversion Factors, and Abbreviations and Acronyms}

\section{Conversion Factors}

SI to Inch/Pound

\begin{tabular}{lcl}
\hline \multicolumn{1}{c}{ Multiply } & \multicolumn{1}{c}{ By } & \multicolumn{1}{c}{ To obtain } \\
\hline millimeter $(\mathrm{mm})$ & Length & \\
meter $(\mathrm{m})$ & 0.03937 & inch (in.) \\
kilometer $(\mathrm{km})$ & 3.281 & foot (ft) \\
\hline & 0.6214 & mile (mi) \\
\hline meter per second $(\mathrm{m} / \mathrm{s})$ & Flow rate & \\
cubic meter per second $\left(\mathrm{m}^{3} / \mathrm{s}\right)$ & 3.281 & foot per second (ft/s) \\
\hline & 70.07 & acre-foot per day (acre-ft/d) \\
\hline gram (g) & Mass & \\
\hline & 0.03527 & ounce, avoirdupois (oz) \\
\hline Millibar (mbar) & Pressure & \\
\hline
\end{tabular}

Temperature in degrees Celsius $\left({ }^{\circ} \mathrm{C}\right)$ may be converted to degrees Fahrenheit $\left({ }^{\circ} \mathrm{F}\right)$ as follows:

${ }^{\circ} \mathrm{F}=\left(1.8 x^{\circ} \mathrm{C}\right)+32$.

\section{Abbreviations and Acronyms}

BSNE

HFE

MFS

RFS

$\mathrm{RH}$
Big Spring Number Eight high-flow experiment modern fluvial sourced relict fluvial sourced relative humidity 


\title{
2010 Weather and Aeolian Sand-Transport Data from the Colorado River Corridor, Grand Canyon, Arizona
}

\author{
By Timothy P. Dealy, Amy E. East, and Helen C. Fairley
}

\begin{abstract}
Measurements of weather parameters and aeolian sand transport were made in 2010 near selected archeological sites in the Colorado River corridor through Grand Canyon, Arizona. Data collected in 2010 indicate event- and seasonal-scale variations in rainfall, wind, temperature, humidity, and barometric pressure. Differences in weather patterns between 2009 and 2010 included a slightly later spring windy season, greater spring precipitation and annual rainfall totals, and a later onset and length of the reduced diurnal barometric-pressure fluctuations commonly associated with summer monsoon conditions. The increase in spring precipitation was consistent with the 2010 spring El Niño conditions compared to the 2009 spring La Niña conditions, whereas the subsequent transition to an El Niño-Southern Oscillation neutral phase appeared to delay the reduction in diurnal barometric fluctuations.
\end{abstract}

\section{Introduction}

This report summarizes high-resolution measurements of wind speed and direction, rainfall, air temperature, barometric pressure, and relative humidity made during calendar year 2010 at weather stations operated by the U.S. Geological Survey Grand Canyon Monitoring and Research Center in the Colorado River corridor in Grand Canyon National Park, Arizona. These stations provide meteorological data for the interior of Grand Canyon that complement daily temperature and rainfall measurements made by the National Park Service near river mile 88 (fig. 1). In addition to meteorological information collected by the weather stations, sand traps deployed near each weather station collect aeolian (windblown) sand from which seasonal sand-transport rates are estimated.

Calendar year 2010 is the fourth consecutive year that weather stations have operated continuously at the same locations in the Colorado River corridor in Grand Canyon National Park. Before 2007, Draut and Rubin (2005, 2006, 2007, 2008) maintained anemometers and tipping bucket rain gages at some of these same locations, as well as at several additional locations in the Colorado River corridor. Following a 1-year hiatus, and in conjunction with a new monitoring and research initiative (Fairley and others, 2007), 9 weather stations and 10 sand traps were installed in 2007 near 7 archaeological sites; 2 additional weather stations and 4 more sets of sand traps were installed in 2008, bringing to 11 and 14 the total number of weather stations and sand traps deployed in Grand Canyon. Previous annual reports documented the data collected in 2007, 2008, and 2009 (Draut and others, 2009a, 2009b, 2010.) 
This report follows Draut and Rubin (2008) and Draut (2012) in referring to aeolian sand deposits as belonging to one of two types-modern fluvial sourced (MFS) and relict fluvial sourced (RFS) deposits. The two types of aeolian deposits are distinguishable by their surface characteristics, particularly the abundance of biologic soil crust (Draut, 2012), and are defined by their position relative to modern fluvial sandbars (those that formed at river flows of $1,270 \mathrm{~m}^{3} / \mathrm{s}$ or less) that could have provided windblown sand for their formation. MFS dune fields are situated directly downwind of active (postdam) fluvial sandbars and were formed as the wind moved sand inland from those sandbars, creating dune fields. RFS deposits, in contrast, formed as wind reworked sediment from older (pre-dam), high-elevation flood deposits, forming aeolian sand dunes from sediment left by floods that were larger than any post-dam floods. At times, RFS dunes may receive some sand from modern sandbars under certain wind directions; however, the major source of sand for these dunes is older deposits left by floods greater than $1,270 \mathrm{~m}^{3} / \mathrm{s}$.

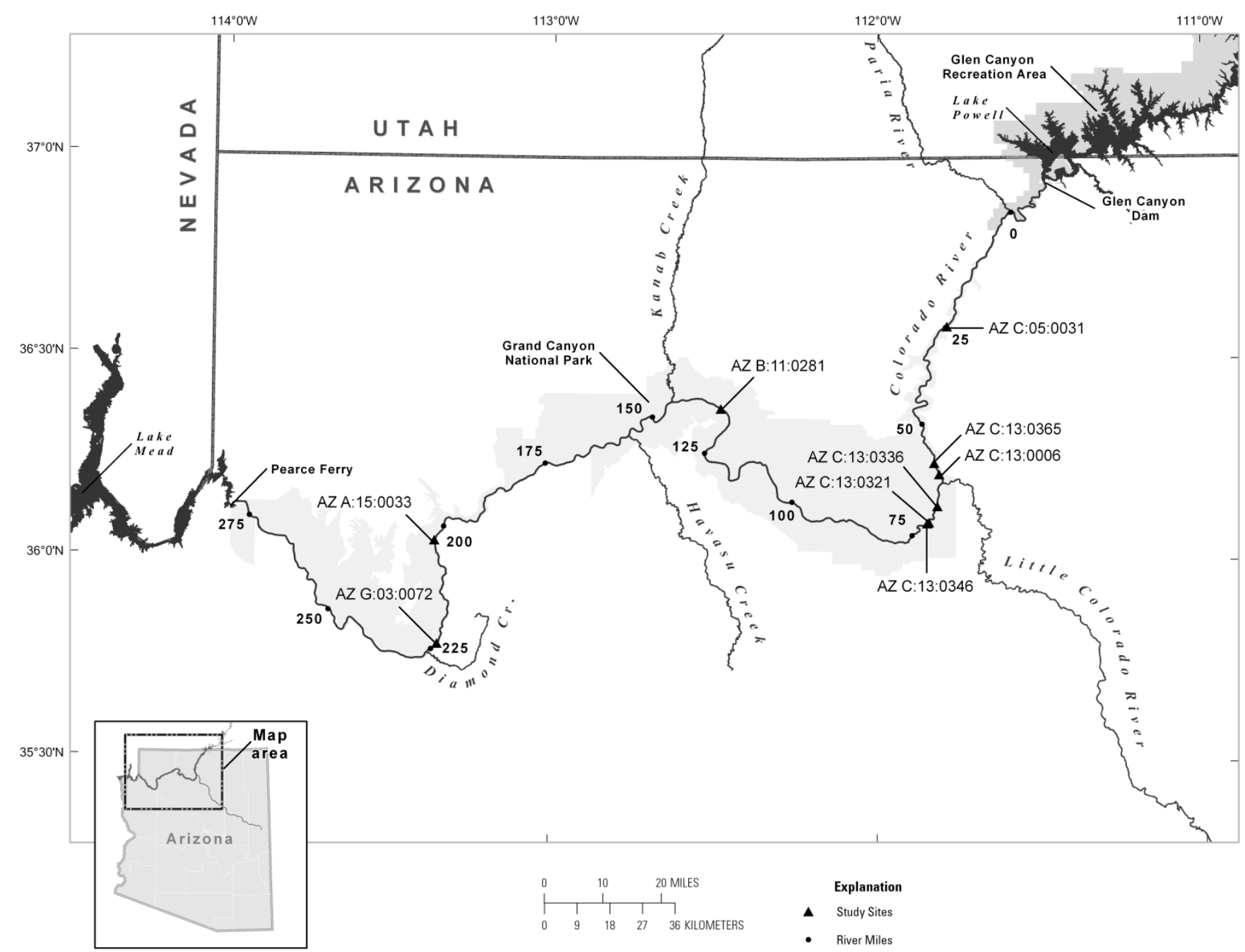

Figure 1. Map showing locations of study sites in Colorado River corridor through Grand Canyon, Arizona. The river reach between Lees Ferry and Little Colorado River is known as Marble Canyon and river miles indicate the distance downstream of Lees Ferry, Arizona. 


\section{Project Objectives}

The weather data described in this report were collected as part of a larger research effort focused on developing standardized, replicable, quantitative monitoring protocols for measuring ecosystem processes affecting archaeological site stability in the Colorado River corridor of Grand Canyon National Park, Arizona. Methods are being developed, as a part of this larger project, to assess the relation between physical landscape processes, including weather and aeolian sediment transport, and the physical integrity of archeological sites. Objectives specific to the weather monitoring component of this project include

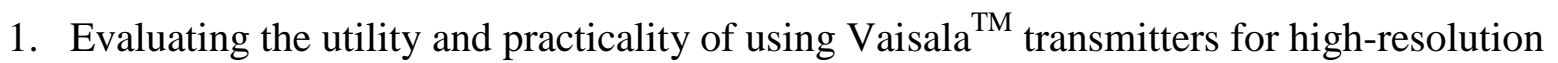
monitoring of local weather conditions in the remote, logistically challenging environment of the inner Grand Canyon;

2. Evaluating the spatial and temporal variability of weather parameters at select sites distributed throughout the Colorado River corridor in Grand Canyon;

3. Evaluating the effects of weather and sediment transport on the physical condition of archaeological sites there; and

4. Applying the methods developed through this project to evaluate the effects of experimental high-flow releases from Glen Canyon Dam on downstream resources, including sandbars, aeolian dunes, and archeologically sensitive areas.

This report is focused primarily on results related to objective 2. Objective 1 was addressed in a previous publication (Draut and others, 2009a), whereas objective 4 was addressed previously by Draut and others (2009b, 2010) and Draut (2012). Objective 3 has been addressed partially in reports by Collins and others (2009, 2012), and is the subject of continuing research.

The physical processes represented by data collected in this study include seasonal weather cycles of wind intensity, humidity, barometric pressure, and precipitation patterns, and individual storm events. High-resolution weather data, when combined with high-resolution topographic surveys, form one basis from which to assess potential or measured effects of Glen Canyon Dam operations on archaeological sites in the Colorado River corridor (Fairley and Sondossi, 2010). Additionally, when compiled into decadal-scale records, weather data such as these can be used to identify regional climatic trends. Given that in recent years the Colorado River Basin has warmed more than other areas of the United States (Saunders and others, 2008), records such as these may prove valuable to a wide range of ecosystem studies. 


\section{Methods}

Since early 2007, nine instrument stations have operated near seven archeological sites in the Colorado River corridor indicated in figure 1: AZ C:05:0031, AZ C:13:0006, AZ C:13:0336, AZ C:13:0346, AZ B:11:0281, AZ A;15:0033, and AZ G:03:0072. In February 2008, two additional instrument stations were deployed near site AZ C:13:0365 (AZ C:13:0365 L and U), and new sand traps were deployed near AZ C:13:0321 and AZ C:13:0336 (AZ C:13:0336 L) in order to collect data relevant to the March 2008 high-flow experiment (HFE). All these instrument stations continued operating throughout 2010. Each "instrument station" consists of one weather station and one set of sand traps. At sites AZ C:05:0031, AZ C:13:0365, and AZ C:13:0346, two independent instrument stations operate approximately $80 \mathrm{~m}$ apart from each other in order to resolve differences in weather and aeolian sand transport that occur at varying elevations and distances from the river. At sites AZ C:13:0336 and AZ G:03:0072, an additional set of sand traps is present approximately $40 \mathrm{~m}$ away from the weather station, closer to the river. The names of each station in this report, the locations of the study sites by approximate river mile, the date the instruments were installed, the type of equipment that operated at each site in 2010, and the general setting of each dune field (MFS, RFS, or other type) are shown in table 1 .

Table 1. Station names, approximate river miles, equipment deployed at each study site, date at which each station was established, and type of aeolian setting at each study site, Colorado River corridor, Grand Canyon, Arizona.

[Dune field type: MFS, Modern Fluvial Sourced; RFS, Relict Fluvial Sourced; Intermediate, combination of MFS and RFS]

\begin{tabular}{lclll}
\hline \multicolumn{1}{c}{ Station name } & $\begin{array}{c}\text { Approximate } \\
\text { river mile }\end{array}$ & \multicolumn{1}{c}{ Equipment } & Date established & \multicolumn{1}{c}{ Dune field type } \\
\hline AZ C:05:0031L & 25 & Weather station, sand traps & $2 / 23 / 2007$ & MFS \\
AZ C:05:0031U & 25 & Weather station, sand traps & $2 / 23 / 2007$ & MFS \\
AZ C:13:0365L & 60 & Weather station, sand traps & $2 / 09 / 2008$ & MFS \\
AZ C:13:0365U & 60 & Weather station, sand traps & $2 / 09 / 2008$ & MFS \\
AZ C:13:0006 & 60 & Weather station, sand traps & $2 / 25 / 2007$ & Intermediate \\
AZ C:13:0336U & 65 & Weather station, sand traps & $2 / 26 / 2007$ & RFS \\
AZ C:13:0336L & 65 & Sand traps & $2 / 10 / 2008$ & Cobble bar \\
AZ C:13:0321 & 70 & Sand traps & $2 / 10 / 2008$ & MFS \\
AZ C:13:0346U & 70 & Weather station, sand traps & $2 / 27 / 2007$ & RFS \\
AZ C:13:0346L & 70 & Weather station, sand traps & $2 / 27 / 2007$ & RFS \\
AZ B:11:0281 & 135 & Weather station, sand traps & $3 / 04 / 2007$ & Intermediate \\
AZ A:15:0033 & 203 & Weather station, sand traps & $3 / 07 / 2007$ & RFS \\
AZ G:03:0072U & 223 & Weather station, sand traps & $3 / 08 / 2007$ & MFS \\
AZ G:03:0072L & 223 & Sand traps & $3 / 08 / 2007$ & MFS \\
\hline
\end{tabular}


Study sites were selected to provide data relevant to monitoring the changing condition and stability of nearby archeological sites where topographic surveys were conducted (Collins and others, 2009, 2012; O’Brien and Pederson, 2009). Instrument stations were deployed near archeological sites (but not near enough to disturb any cultural features or artifacts). Several of the study sites were selected because of their apparent responsiveness to experimental sandbar-building flows in 1996 and 2004 (Draut and Rubin, 2006). These sites were retained for this study in order to extend weather records at these locations and to be able to compare results from previous high-flow experiments (HFEs) with future HFEs. Study sites were distributed along the river corridor between upper Marble Canyon (approximately river mile 25) and the western Grand Canyon (approximately river mile 225) in order to record spatial variations in weather patterns throughout the river corridor (fig. 1).

\section{Monitoring Weather Parameters}

Specifications of the weather stations were established and fine-tuned during 2007; details of equipment design and modifications made for use in Grand Canyon were discussed by Draut and others (2009a). All weather stations used for this study are configured identically and consist of a transmitter and data logger mounted on a tripod (fig. 2). The transmitter, a Vaisala ${ }^{\mathrm{TM}}$ multi-parameter weather transmitter, model WXT510/520 with serial data interface SDI-12, is mounted $2 \mathrm{~m}$ above ground level. The data logger is a Nexsens ${ }^{\mathrm{TM}}$ iSIC logger upgraded to 2 megabytes of memory. The system is powered by an Optima ${ }^{\mathrm{TM}}$ D34/78 deep-cycle $12 \mathrm{~V}$ battery (AGM type, $55 \mathrm{Ah}$ ) housed in a box on the ground and charged by a south-facing 30-watt, 12 VDC solar panel mounted on the tripod. Solar panels are the BPSX30U model made by BP Solar ${ }^{\mathrm{TM}}$, modulated by a SK-6 Morningstar Solar ${ }^{\mathrm{TM}} 12$ VDC, 6A controller. The manufacturer's stated measurement range for wind speed measured by the Vaisala ${ }^{\mathrm{TM}}$ WXT510/520 transmitter is $0-60 \mathrm{~m} / \mathrm{s}$, with an accuracy of $\pm 0.3 \mathrm{~m} / \mathrm{s}$ or \pm 3 percent, whichever is greater, for wind speeds of $0-35 \mathrm{~m} / \mathrm{s}$. For wind speeds of 36-60 m/s, accuracy is \pm 5 percent. The measurement range for wind direction is $360^{\circ}$, with an accuracy of $\pm 3^{\circ}$. We assume an additional $5^{\circ}$ margin for error incurred by the user when aligning the transmitter with true North for a total estimated wind-direction accuracy of $\pm 8^{\circ}$. The transmitter has an estimated response time of $250 \mathrm{~ms}$ for detecting wind speed and direction. For this study, wind speed and direction are recorded every 4 minutes, with each data record consisting of the 4-minute averaged wind speed, the 4-minute averaged wind direction, and the speed and direction of the highest gust during each 4-minute interval (gust speed measured as 3-second average). A 4-minute interval was selected as the highest resolution that can be used given the capacity of memory in the data loggers and the length of time between data download (often several months).

A pressure sensor on the Vaisala ${ }^{\mathrm{TM}}$ WXT510/520 transmitter detects rainfall with a resolution of $0.01 \mathrm{~mm}$ and 5 percent accuracy according to the manufacturer. Rainfall is recorded on the data logger at 4-minute intervals as a 4-minute total amount. Air temperature, relative humidity, and barometric pressure are recorded by a separate sensor within the shaded housing of the transmitter. Air temperature from -52 to $+60{ }^{\circ} \mathrm{C}$ is recorded with an accuracy of $\pm 0.3^{\circ} \mathrm{C}$ at $20^{\circ} \mathrm{C}$. Relative humidity (RH) from 0 to 90 percent is measured with an accuracy of \pm 3 percent, whereas RH from 90 to 100 percent is measured with an accuracy of \pm 5 percent. The transmitter measures barometric pressure between 600 and 1,100 mbar with an accuracy of \pm 0.5 mbar at $0-30{ }^{\circ} \mathrm{C}$ and \pm 1 mbar less than $0{ }^{\circ} \mathrm{C}$ or greater than $30{ }^{\circ} \mathrm{C}$. Temperature, relative humidity, and barometric pressure are recorded on the data logger at 4-minute intervals as 4-minute averages. 
Weather stations are camouflaged using paint and burlap to reduce their visibility. Stations were visited for maintenance and data downloading every 12-18 weeks during 2010. All transmitters were replaced during 2009 and 2010 and sent to Vaisala ${ }^{\mathrm{TM}}$ for calibration; all were found to have been operating within the manufacturer's stated accuracy ranges during 2010 (Vaisala, 2008; Vaisala, n.d.).

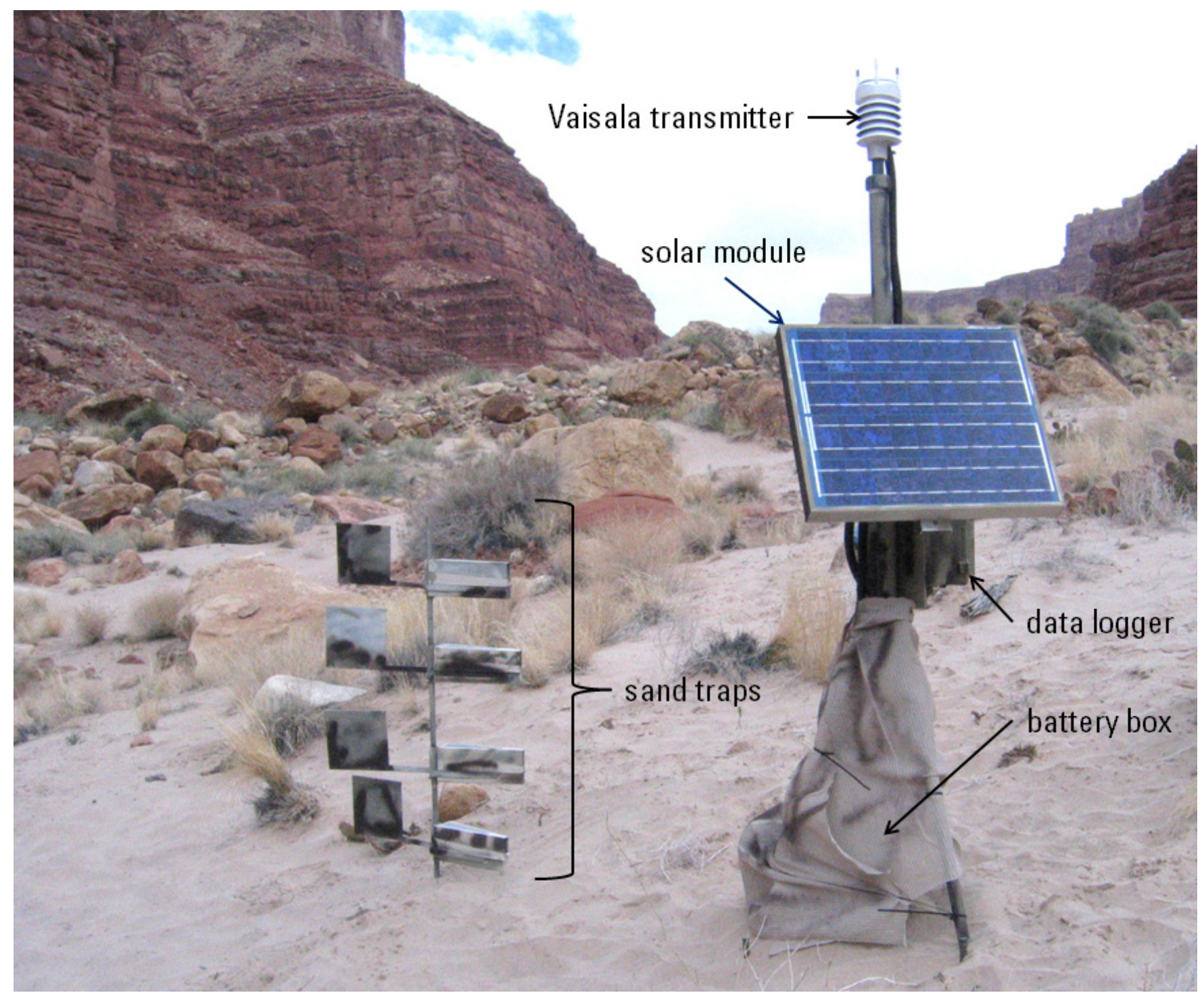

Figure 2. Photograph of instrument station near AZ C:05:0031 L in Grand Canyon, Arizona. The transmitter, data logger, and solar module are mounted on a tripod, and the system is powered by a battery housed in a box on the ground. The pole with four sand traps on it is approximately 3 meters away from the tripod. 


\section{Monitoring Aeolian Sediment Transport}

Aeolian sediment transport was monitored at each study site using wedge-shaped, galvanized metal “Big Spring Number Eight” (BSNE) passive-sampling sand traps (Fryrear, 1986). Sand traps were emptied during maintenance visits to the instrument stations. To obtain an informative sampling resolution, it generally is necessary to empty sand traps at least once every 12-18 weeks; however, during 2010, some intervals between sand-trap maintenance visits were longer than 18 weeks, reducing the sampling resolution for the aeolian sand-transport measurements. Therefore, sediment-transport measurements were based on cumulative values representing the interval between visits, and were calculated as daily transported mass (in grams per centimeter trap width). Sediment samples were collected from traps in the field and brought back to a laboratory at Northern Arizona University to be weighed. Organic material was removed from the sediment by treating the samples with hydrogen peroxide. Samples were dried overnight in an oven at $80{ }^{\circ} \mathrm{C}$, allowed to cool in a desiccant chamber, and weighed on a scale with precision to $0.0001 \mathrm{~g}$.

BSNE sand traps in sets of four deployed on a vertical pole were used in this study, with the orifices of the four traps set at heights of $0.1,0.4,0.7$, and $1.0 \mathrm{~m}$ above the ground surface (fig. 2). Each trap is equipped with a vane that turns the trap into the wind. The BSNE design is used widely in agricultural and geologic studies of windblown sediment, in part because its shape allows it to perform nearly isokinetically, causing minimal distortion of air flow at the sampling orifice (Stout and Fryrear, 1989; Nickling and Neuman, 1997; Zobeck and others, 2003). The sampling orifice measures $5 \mathrm{~cm}$ tall by $2 \mathrm{~cm}$ wide; air flow enters the trap through the orifice and exits through a 60-mesh screen in the upper surface of the trap. Sediment is retained in the lower one-half of the trap after falling through a wider (18-mesh) screen. Wind-tunnel studies (Goossens and others, 2000) indicate an efficiency range of 70 to 130 percent for BSNE sand traps for the wind velocities and sediment grain sizes encountered in Grand Canyon. Efficiency less than 100 percent indicates that air flow is directed away from the orifice, such that the trap undersamples windblown sediment, whereas efficiency greater than 100 percent indicates that air flow is directed into the trap, oversampling windblown sediment. An efficiency range of 70 to 130 percent was used to estimate error in the sand-transport data reported here. This conservative treatment of the data is the best available for the bulk sand-transport data reported here; the exact correspondence between wind velocities and local sand-transport rates is unknown.

To represent the sand-transport potential for a given wind velocity, a proxy variable, $Q p$, was used, which is defined as:

$$
Q p=\left(u-u_{\text {crit }}\right)^{3}
$$

where $Q p$ is potential sand flux, in cubic meters per cubic second $\left(\mathrm{m}^{3} / \mathrm{s}^{3}\right)$,

$u$ is the wind velocity, in meters per second $(\mathrm{m} / \mathrm{s})$, and

$u_{\text {crit }}$ is the critical threshold of motion $(\mathrm{m} / \mathrm{s})$. 
The relation in equation 1 follows the convention used to construct aeolian-sediment-transport models, such as those of Kawamura (1951) and Lettau and Lettau (1977), but substitutes wind velocity for shear velocity. Although the units of $Q p\left(\mathrm{~m}^{3} / \mathrm{s}^{3}\right)$ do not translate directly to a sand flux, the $Q p$ value for each site over a given time interval serves as a proxy indicating potential for sand transport. $Q p$ was calculated for all data points at which $u$ exceeded $u_{\text {crit }}$. The critical threshold of motion is assumed to be $2 \mathrm{~m} / \mathrm{s}$ based on sediment grain size measured for these study sites and other surficial sediment deposits in the Grand Canyon (Bagnold, 1941; Draut and Rubin, 2005, 2008). For the data points at which $u$ was less than $u_{c r i t}, Q p$ was set equal to zero, indicating that no sand transport would occur. Dominant wind directions causing sand transport then were calculated by using vector sums of $Q p$ values from the 4minute wind measurements. Vector-sum calculations also were made after eliminating wind measured within 48 hours after a rainfall event, the amount of time (based on field observations at different times of year) after which sand generally is sufficiently dry to be mobilized by wind.

\section{Results}

Daily rainfall recorded at each weather station during 2010 is shown in table 2 (at back of report). Monthly vector sums of aeolian sand-transport potential at each station are shown in table 3 (at back of report). $Q p$ vector sums calculated using all available wind data are shown in table $3 A$, and vector sums for dry conditions are shown in table $3 B$.

\section{Site-Specific Data}

The following sections describe the setting of each weather station, any problems with instrument performance, and site-specific findings from 2010. The station numbers reference nearby archeological sites and are presented in geographic order, starting with the farthest-upstream station and proceeding downstream.

\section{Site AZ C:05:0031}

Two weather stations operated throughout 2010 in an aeolian dune field on the downstream side of a debris fan at site AZ C:05:0031-one near river level (AZ C:05:0031 L) and one at the upper end of the dune field (AZ C:05:0031 U). Equipment malfunctions did not occur at either weather station in 2010. The dune field between the two weather stations at site AZ C:05:0031 undergoes active sand transport and has moderate vegetation and little biological soil crust (vegetation and biological soil crust were quantified at each study site in 2009; these data are presented in a separate report by Draut (2011). An approximately equal area at the northern (upstream) end of the dune field is relatively inactive, with well-developed biological soil crust and evident deflation of the land surface. Draut and Rubin (2008) identified this dune field as a modern fluvial sourced (MFS) aeolian deposit, based on observations between 2003 and 2006 of net sediment-transport potential from the direction of a river-level sandbar. However, some of the sand in this area apparently was deposited by predam floods and by exceptionally high post-dam flows in 1983, based on its topographic position relative to modeled water-surface elevations (Magirl and others, 2008) and the presence of a penny, dated 1981, found embedded in a fluvial deposit a short distance upstream of the weather station AZ C:05:0031 L. A vector sum of all available wind data from station AZ C:05:0031 L in 2010 yields a net Qp magnitude of 43,465 m ${ }^{3} / \mathrm{s}^{3}$ from a direction of $246^{\circ}$; using wind data collected only during periods when the sand was estimated to have been dry, a vector sum yields a net $Q p$ magnitude of $40,270 \mathrm{~m}^{3} / \mathrm{s}^{3}$ from a direction of $249^{\circ}$ (table 3). These calculations indicate net sand transport generally inland and upstream (fig. 3), with a stronger inland-directed component than was measured at this site in 2009 (net potential sand transport in 2009 was from $215^{\circ}$ at station AZ C:05:0031 L; Draut and others, 2009b), although a directional wind plot shows no strong directional component at station AZ C:05:0031 L in 2010 (fig. 4). 


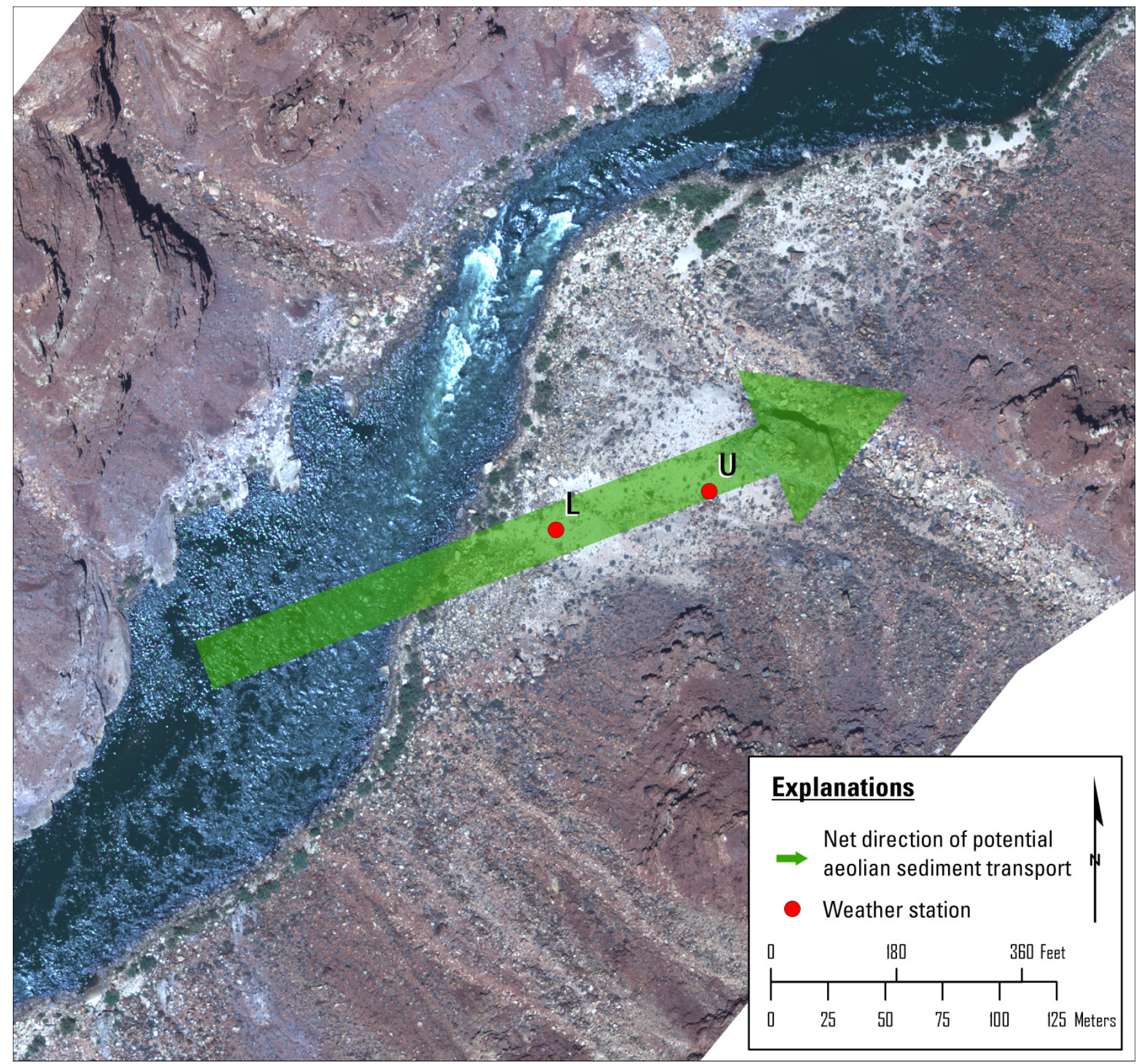

Figure 3. Aerial photograph of the area around site AZ C:05:0031 in Grand Canyon, Arizona. Arrow indicates the net direction of potential aeolian sediment transport measured at AZ C:05:0031 L in 2010. A vector sum of the $Q p$ proxy variable (equation 1), calculated using all wind data collected during dry conditions from station AZ C:05:0031 $L$ in 2010, indicates net sediment transport from $246^{\circ}$. 


\section{Station AZ C:05:0031 L}

\section{4-minute average wind speed, in meters per second}

and wind direction, in degrees True

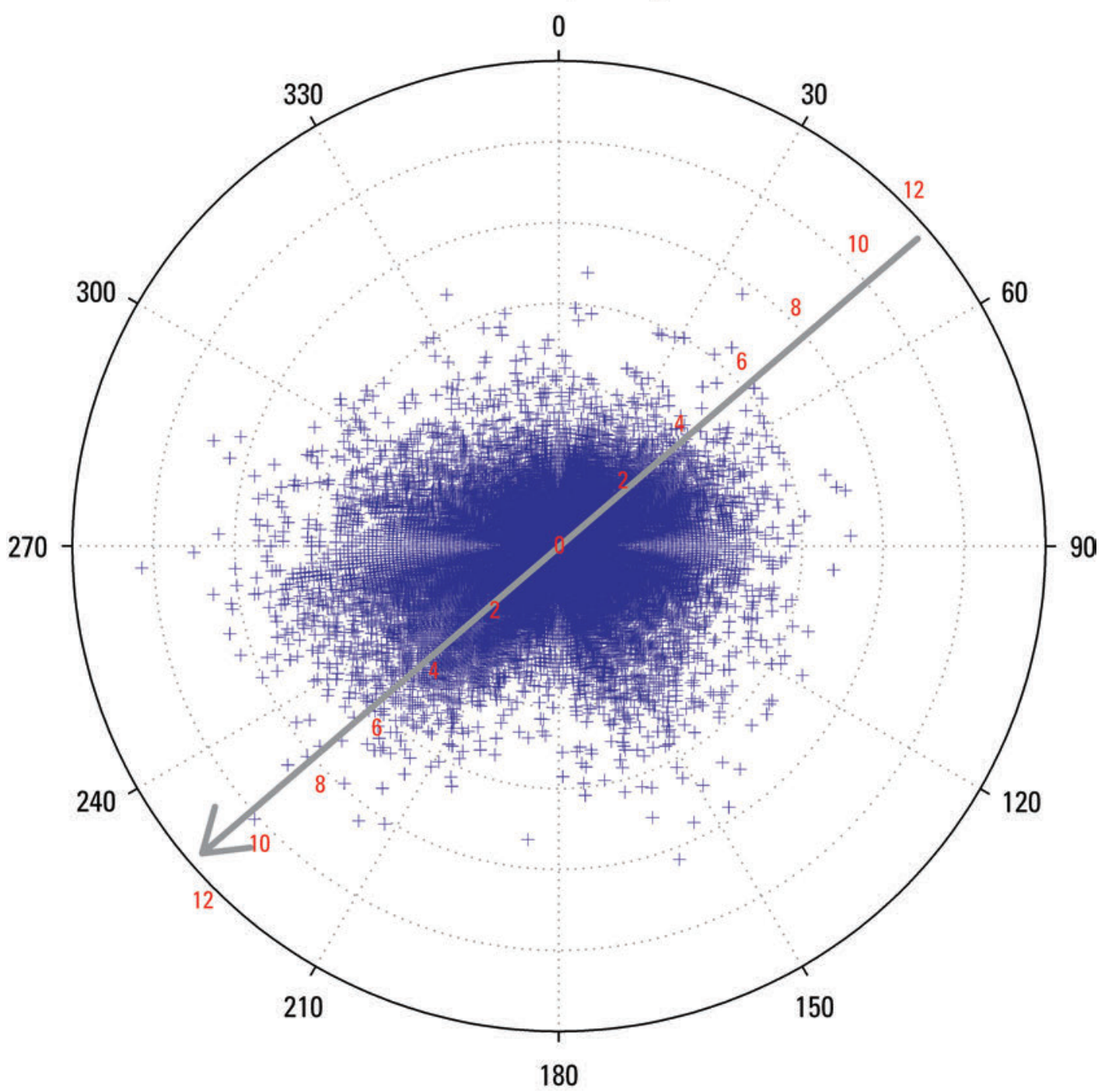

Figure 4. Plot showing magnitude and direction of wind velocity measured at the instrument station $A Z$ C:05:0031 L with 4-minute resolution in Grand Canyon, Arizona, 2010. Magnitude is indicated by the concentric circles, and compass bearing indicates the wind direction. The gray arrow shows the orientation of the river corridor $\left(229^{\circ}\right)$; river flow is toward the southwest. 
The total annual rainfall measured at station AZ C:05:0031 L in 2010 was $369.2 \mathrm{~mm}$ (table 2), more than three times the amount measured there in 2009; cumulative rainfall data for this station are shown in figure 5. All weather parameters and sand transport measured at station AZ C:05:0031 L in 2010 are summarized in figures 6 and 7, with 2009 data shown for comparison.

A vector sum of all available wind data from station AZ C:05:0031 U (approximately $80 \mathrm{~m}$ inland and uphill of station AZ C:05:0031 L) in 2010 yields a net $Q p$ magnitude of 149,490 $\mathrm{m}^{3} / \mathrm{s}^{3}$ from a direction of $245^{\circ}$; using wind data collected only during periods when the sand is estimated to have been dry, a vector sum yields a net $Q p$ magnitude of $107,740 \mathrm{~m}^{3} / \mathrm{s}^{3}$ from a direction of $246^{\circ}$ (fig. 8). These calculations indicate net sand transport generally inland and upstream, although, like at the lower station, the directional wind plot (fig. 9) still shows no strong directional component at station AZ C:05:0031 U.

Total annual rainfall measured at station AZ C:05:0031 U in 2010 was $275.9 \mathrm{~mm}$ (table 2); cumulative rainfall data for this station are shown in figure 10. All weather parameters and sand transport measured at station AZ C:05:0031 U in 2010 are summarized in figures 11 and 12, with 2009 data shown for comparison.

Wind velocities typically are higher at station AZ C:05:0031 U than at station AZ C:05:0031 L, which is attributed to lower vegetation densities at the upper site. Aeolian sand-transport rates measured at station AZ C:05:0031 U also are correspondingly higher than at station AZ C:05:0031 L (figs. 6, 11). At both the upper and lower stations, the highest sand-transport rates in 2010 occurred in the spring, which is commonly observed in Grand Canyon (Draut and Rubin, 2005, 2006; Draut and others, 2009a, 2009b), although the highest wind speeds in 2010 were observed somewhat later (April-May) than in 2009 (in 2009, the windiest season, evaluated by visual inspection of the 4-minute-averaged wind data plots, was uncharacteristically early and spanned March-April). At both stations, aeolian sand-transport rates were somewhat higher in spring 2010 than in spring 2009—by approximately 30 percent—even given the error margin assigned to these data (figs. 6, 11). 


\section{Station AZ C:05:0031 L}

Cumulative rainfall

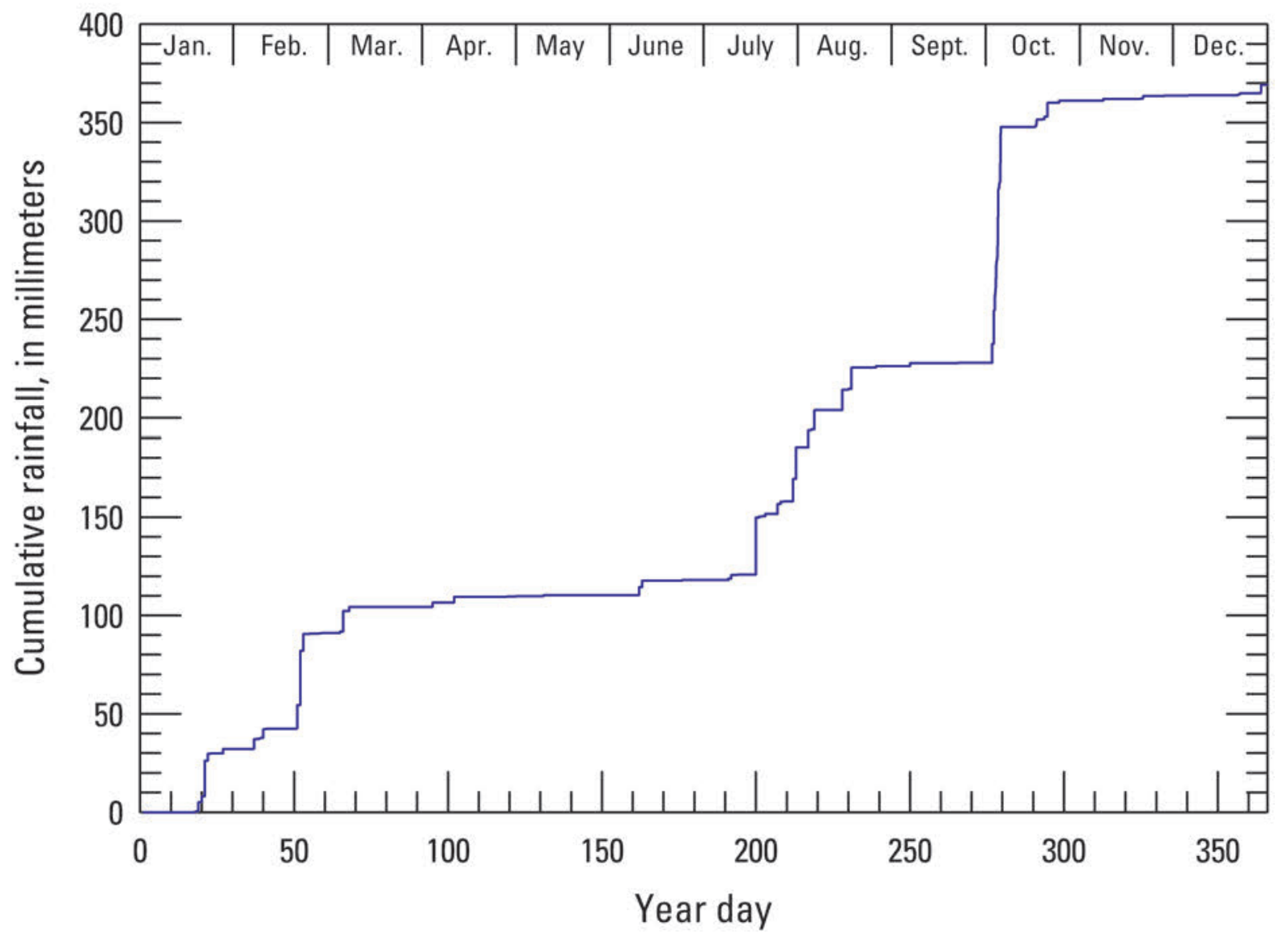

Figure 5. Plot showing cumulative rainfall recorded at station AZ C:05:0031 L compiled from data collected at 4minute resolution in Grand Canyon, Arizona, 2010. 
2009
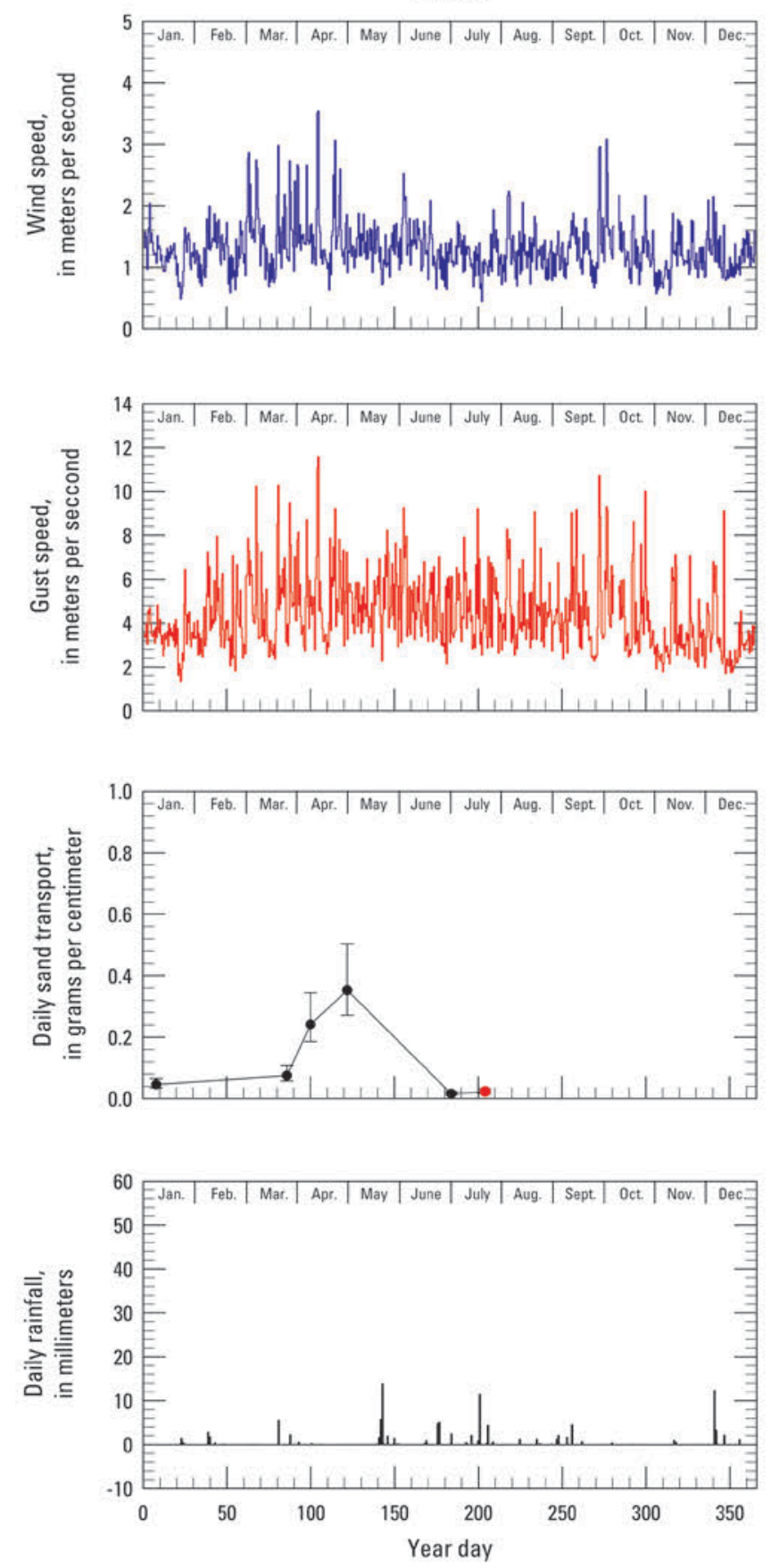

2010
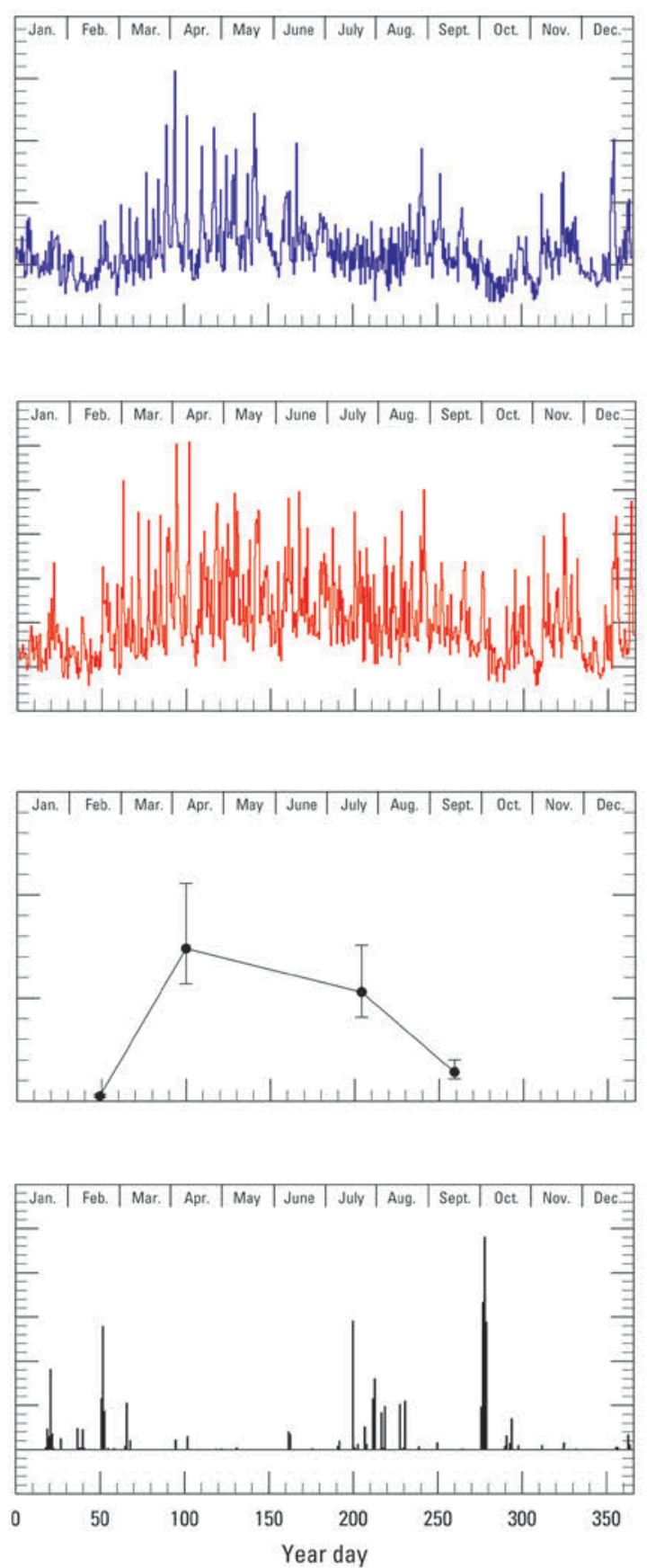

Figure 6. Plots showing wind, aeolian sand-transport, and rainfall data collected at the instrument station AZ C:05:0031 L in Grand Canyon, Arizona, 2009-10. Wind speed is presented as diurnal average values, using daytime (0600-1800 hours) and nighttime (1800-0600 hours) averages of data collected at 4-minute intervals. Gust speed is shown as maximum values that occurred during each diurnal interval. Daily sand transport is plotted in grams, normalized to a width of 1 centimeter. To obtain these values, total sand mass collected from four traps during each maintenance visit was divided by the number of days since the trap had last been emptied. Rainfall is plotted as daily (24-hour) totals. 

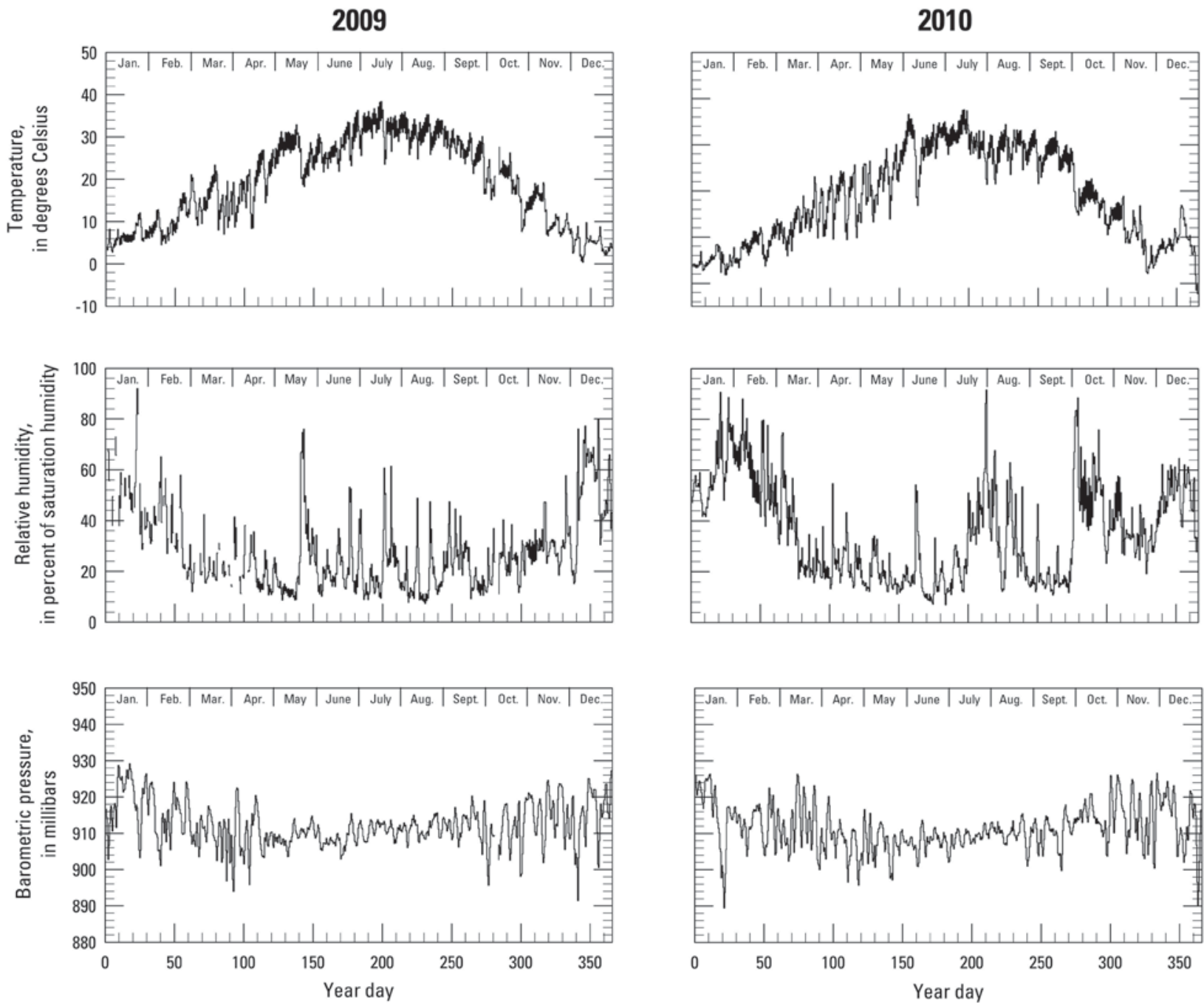

Figure 7. Plots showing temperature, relative humidity, and barometric pressure data collected at instrument station AZ C:05:0031 L in Grand Canyon, Arizona, 2009-10. All parameters are plotted as diurnal averages (defined using 0600-1800 and 1800-0600 hours). 


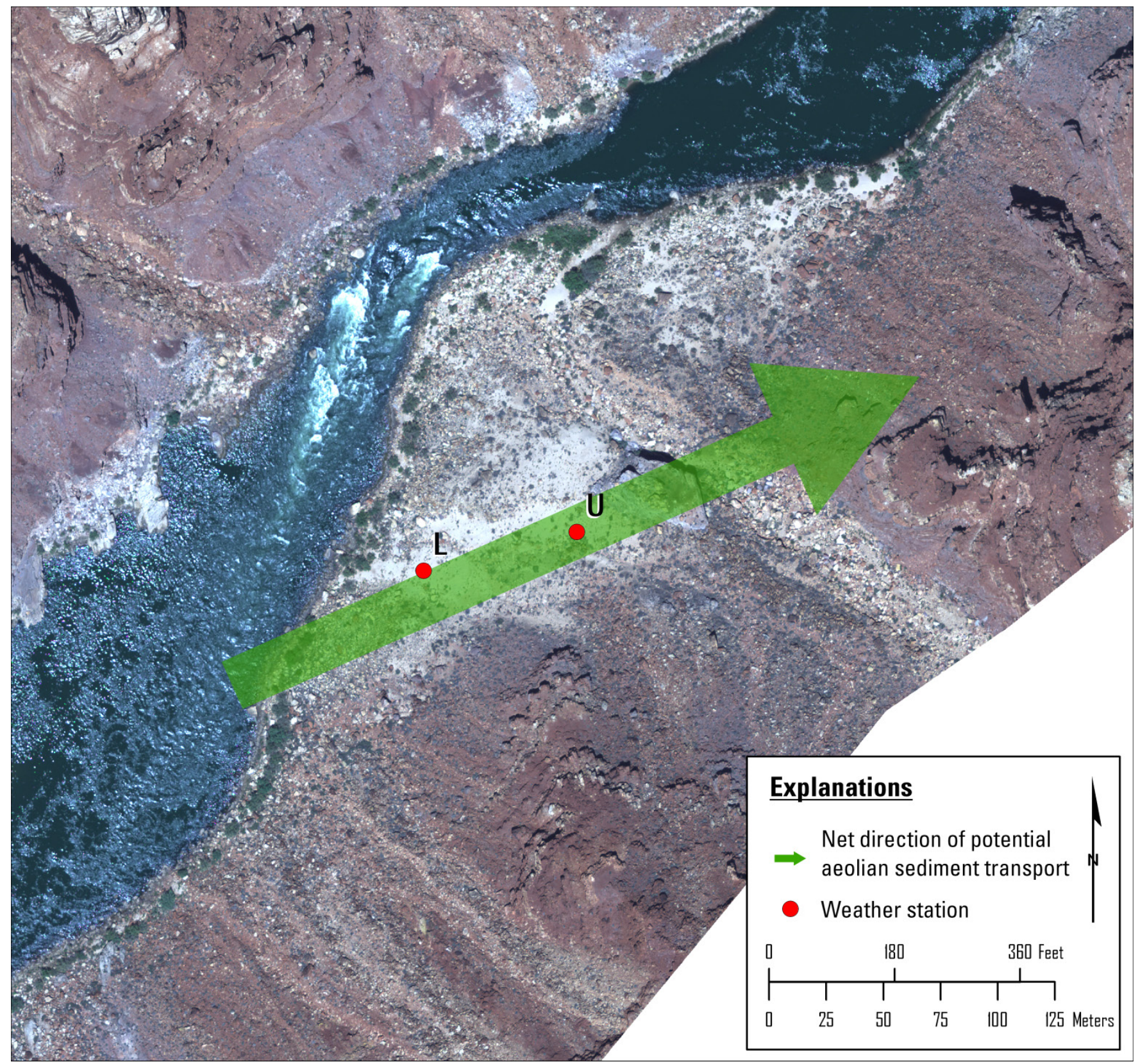

Figure 8. Aerial photograph showing area around site AZ C:05:0031 in Grand Canyon, Arizona. Arrow indicates the net direction of potential aeolian sediment transport measured at AZ C:05:0031 U in 2010. A vector sum of the $Q p$ proxy variable (equation 1), calculated using all the wind data collected during dry conditions from station AZ C:05:0031 U in 2010, indicates net sediment transport from $245^{\circ}$. 


\section{Station AZ C:05:0031 U}

\section{4-minute average wind speed, in meters per second}

and wind direction, in degrees True

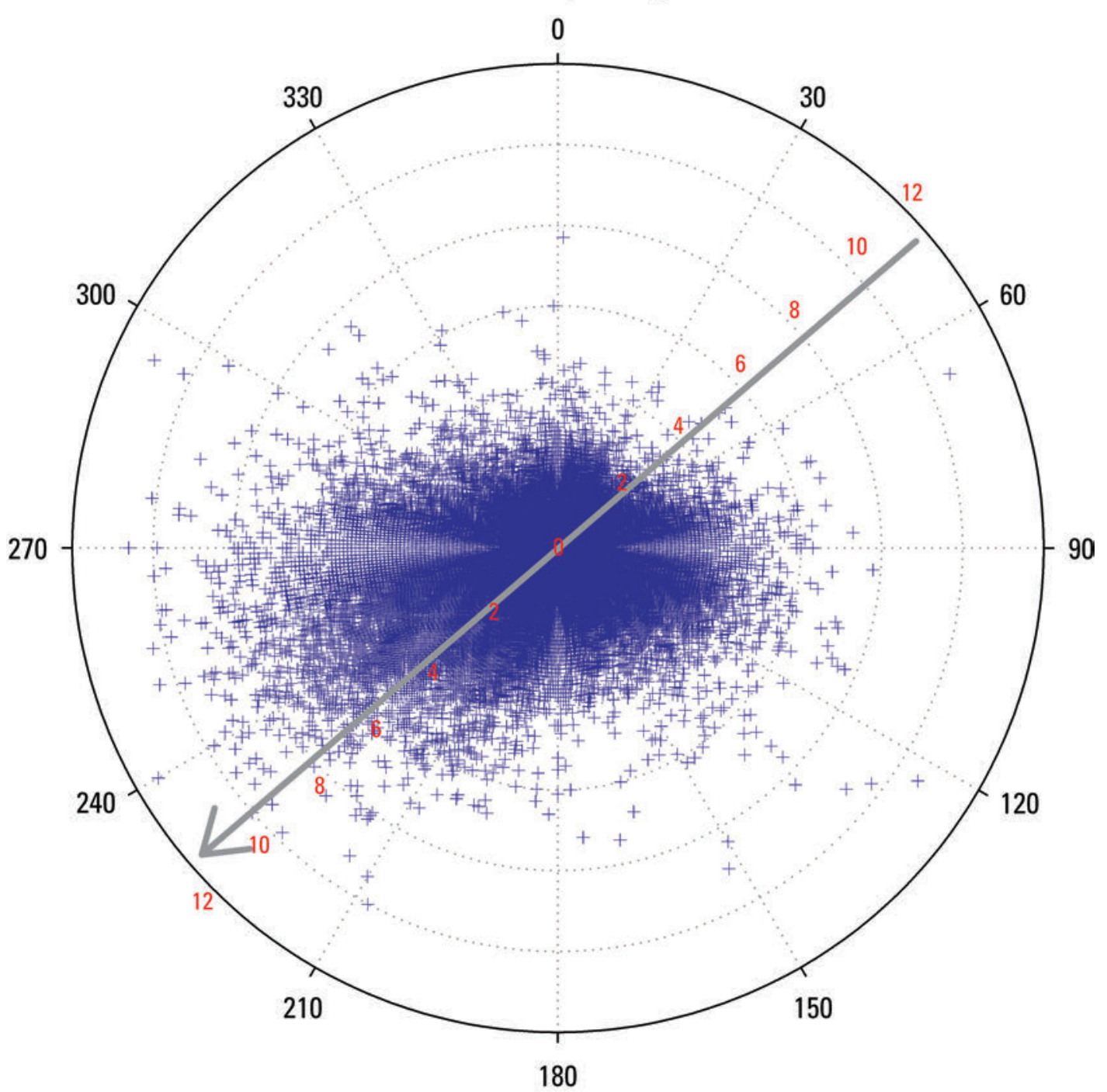

Figure 9. Plot showing magnitude and direction of wind velocity measured at the instrument station AZ C:05:0031 U with 4-minute resolution in Grand Canyon, Arizona, 2010. Magnitude is indicated by the concentric circles, and compass bearing indicates the wind direction. The gray arrow shows the orientation of the river corridor $\left(229^{\circ}\right)$; river flow is toward the southwest. 


\section{Station AZ C:05:0031 U}

Cumulative rainfall

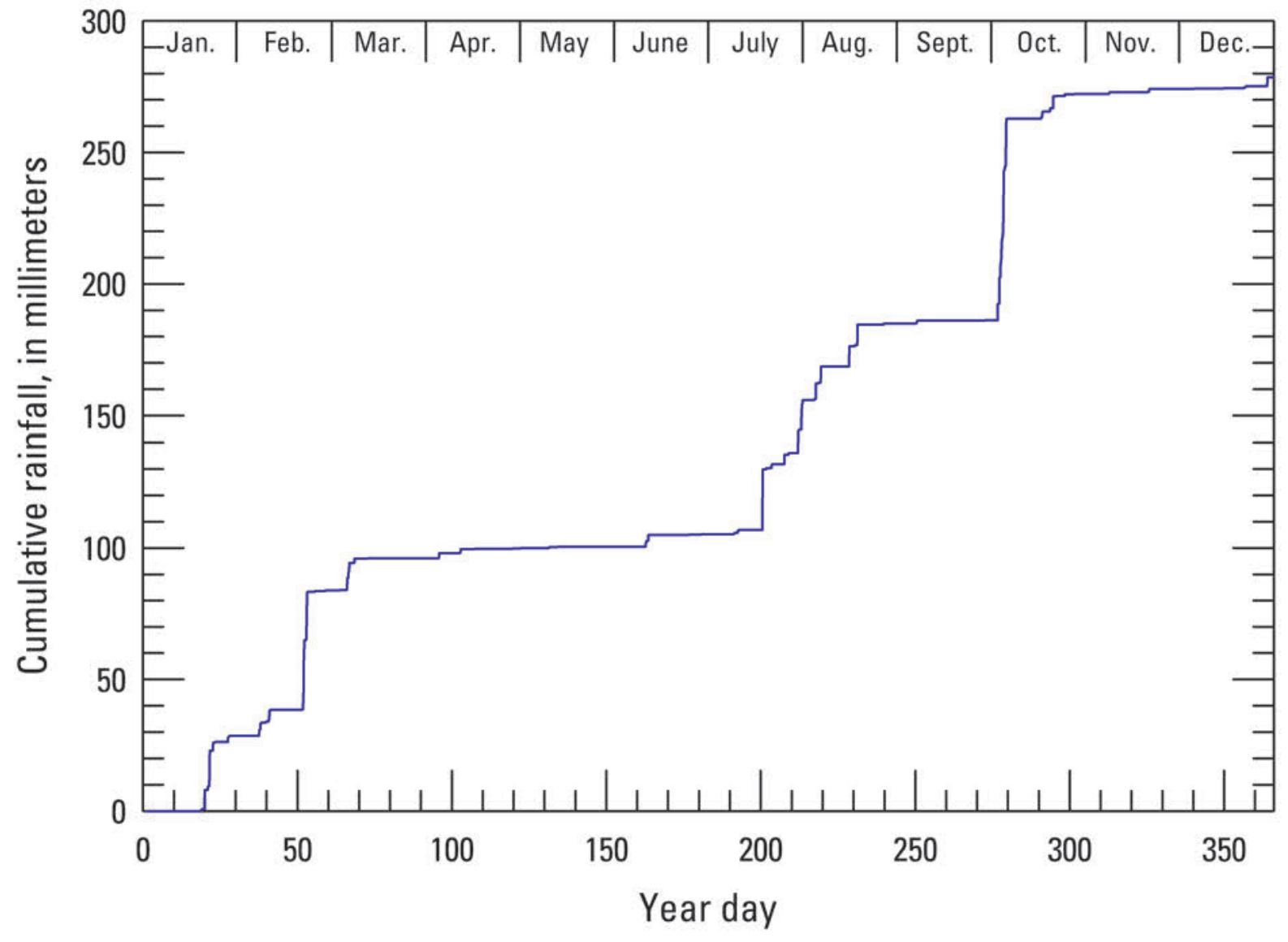

Figure 10. Plot showing cumulative rainfall recorded at station AZ C:05:0031 U compiled from data collected at 4-minute resolution in Grand Canyon, Arizona, 2010. 
2009
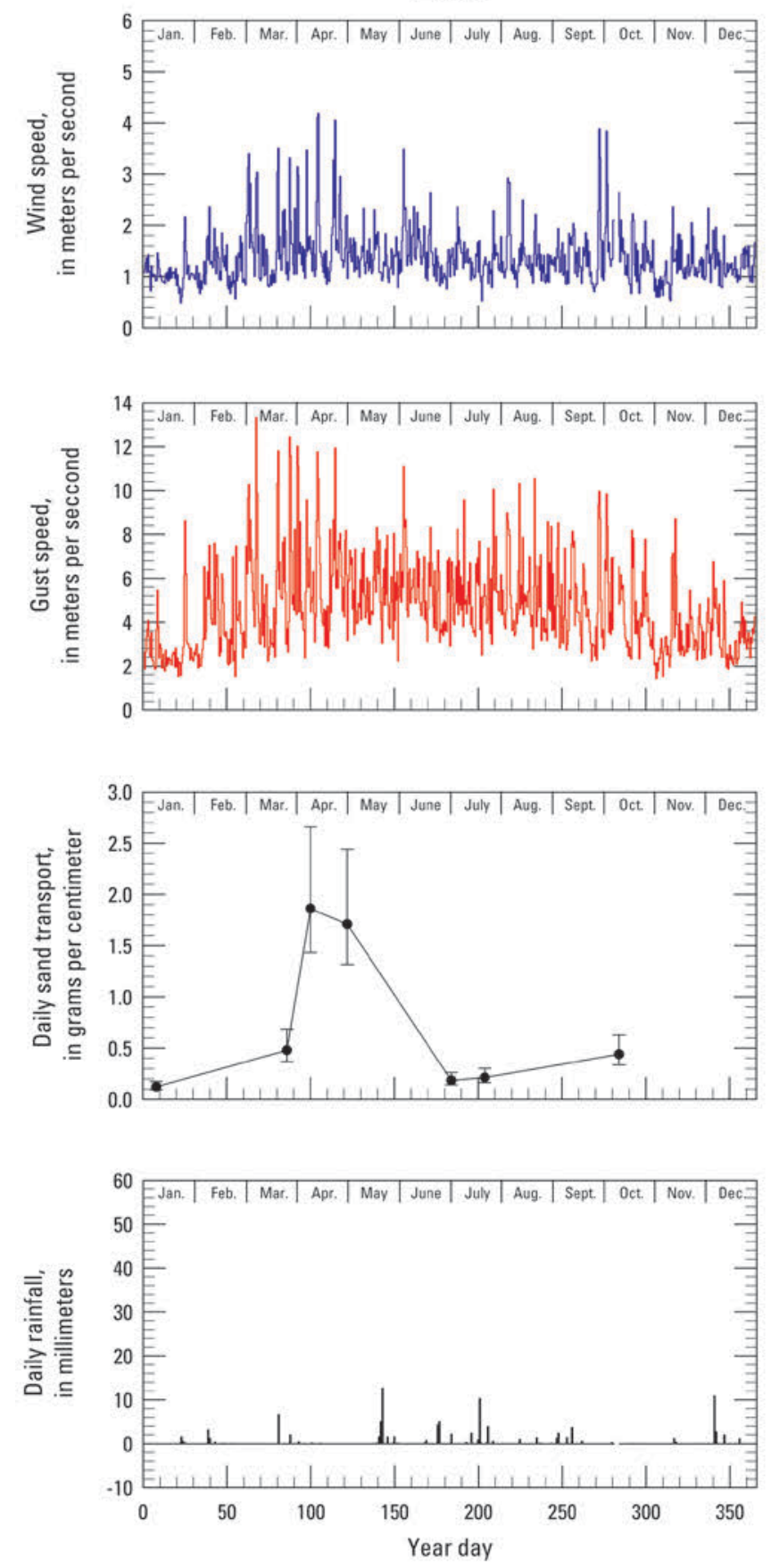

2010
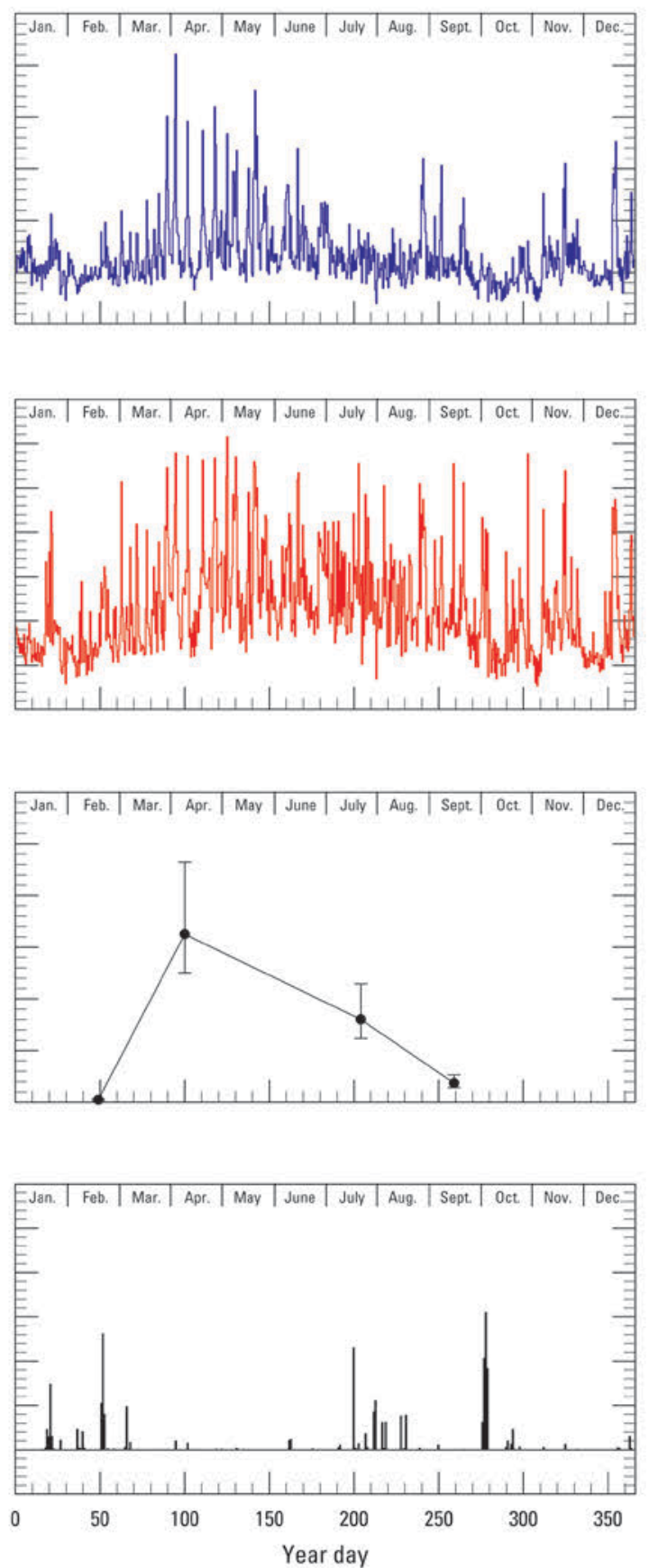

Figure 11. Plots showing wind, aeolian sand-transport, and rainfall data collected at the instrument station AZ C:05:0031 U in Grand Canyon, Arizona, 2009-10. Wind speed is presented as diurnal average values, using daytime (0600-1800 hours) and nighttime (1800-0600 hours) averages of data collected at 4-minute intervals. Gust speed is shown as maximum values that occurred during each diurnal interval. Daily sand transport is plotted in grams, normalized to a width of 1 centimeter. To obtain these values, total sand mass collected from four traps during each maintenance visit was divided by the number of days since the trap had last been emptied. Rainfall is plotted as daily (24-hour) totals. 

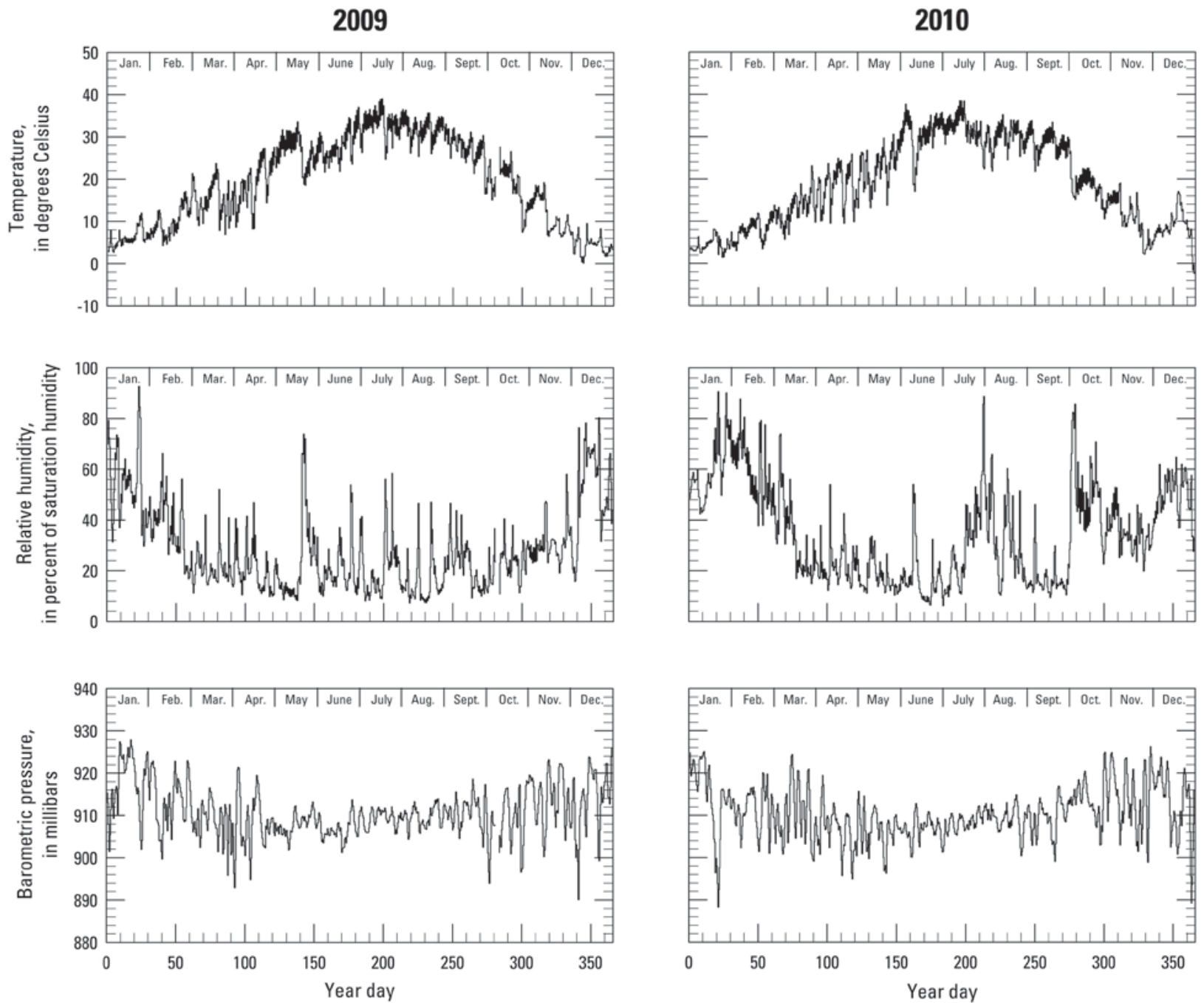

Figure 12. Plots showing temperature, relative humidity, and barometric pressure data collected at instrument station AZ C:05:0031 U in Grand Canyon, Arizona, 2009-10. All parameters are plotted as diurnal averages (defined using 0600-1800 and 1800-0600 hours). 
Two instrument stations, situated in approximately the same locations as those used at this site by Draut and Rubin (2008), have operated near site AZ C:13:0365 since February 2008. The area around site AZ C:13:0365 includes an active aeolian dune field on the downstream side of a side canyon and an associated debris fan; sand-transport rates in this dune field were higher than those measured at any other site by Draut and Rubin (2008). Dune morphology at site AZ C:13:0365 includes north-facing slip faces, consistent with northward dune migration; this morphology combined with dominantly southsoutheast winds identify this site as a modern fluvial sourced (MFS) dune field whose primary sediment source is a fluvial sandbar immediately upwind of the dune field. A second sandbar, across the river and approximately $200 \mathrm{~m}$ downstream, also provides sediment to the dune field near site AZ C:13:0365 (Draut and Rubin, 2008).

A vector sum of all wind data from station AZ C:13:0365 L in 2010 yields a net Qp magnitude of $72,645 \mathrm{~m}^{3} / \mathrm{s}^{3}$ from a direction of $171^{\circ}$; using wind data collected only during periods when the sand is estimated to have been dry, a vector sum yields a net $Q p$ magnitude of 50,596 $\mathrm{m}^{3} / \mathrm{s}^{3}$ from a direction of $170^{\circ}$ (table 3). These calculations indicate net sand transport toward the north-northwest (fig. 13), although the directional wind plot (fig. 14) shows that substantial transport from the north-northwest also can occur at station AZ C:13:0365 L. This is consistent with net potential sand transport measured from 2003 to 2006 and in 2008 and 2009 at this site (Draut and Rubin, 2008; Draut and others, 2009b).

Total rainfall measured at station AZ C:13:0365 L was $421.3 \mathrm{~mm}$ (table 2), much higher than in 2009; cumulative rainfall during 2010 at this station is plotted in figure 15. All weather parameters and sand transport measured at station AZ C:13:0365 L in 2010 are summarized in figures 16 and 17. Sandtransport rates were highest at station AZ C:13:0365 L during late winter 2010 (fig. 16) and were lower in spring 2010 than in spring 2009.

A vector sum of all available wind data from station AZ C:13:0365 U (approximately $50 \mathrm{~m}$ inland and uphill of station AZ C:13:0365 L) in 2010 yields a net $Q p$ magnitude of 1,500,600 $\mathrm{m}^{3} / \mathrm{s}^{3}$ from a direction of $154^{\circ}$; using wind data collected only when the sand is estimated to have been dry, a vector sum yields a net $Q p$ magnitude of 730,990 $\mathrm{m}^{3} / \mathrm{s}^{3}$ from a direction of $154^{\circ}$ (table 3). These calculations indicate net sand transport generally toward upstream (fig. 18), with higher wind speeds and a stronger southeasterly directional component than at the lower-elevation station AZ C:13:0365 L, although strong northwest winds also are present at times (fig. 19). The wind velocities and dominant direction from the southeast at station AZ C:13:0365 U are consistent with wind conditions measured at this site between 2003 and 2006 (Draut and Rubin, 2008) and in 2008 and 2009 (Draut and others, 2009b).

Total rainfall measured in 2009 was $354.8 \mathrm{~mm}$ (table 2) at station AZ C:13:0365 U; cumulative rainfall at this site is plotted in figure 20. All weather parameters and sand transport measured at AZ C:13:0365 U in 2010 are summarized in figures 21 and 22. Sand-transport rates measured during the spring windy season at station AZ C:13:0365 U in 2010 cannot be compared directly with those in 2009, owing to sand-trap malfunctions in early spring 2010 that allowed only minimum transport values to be estimated for 2010 (Draut and others, 2009b). 


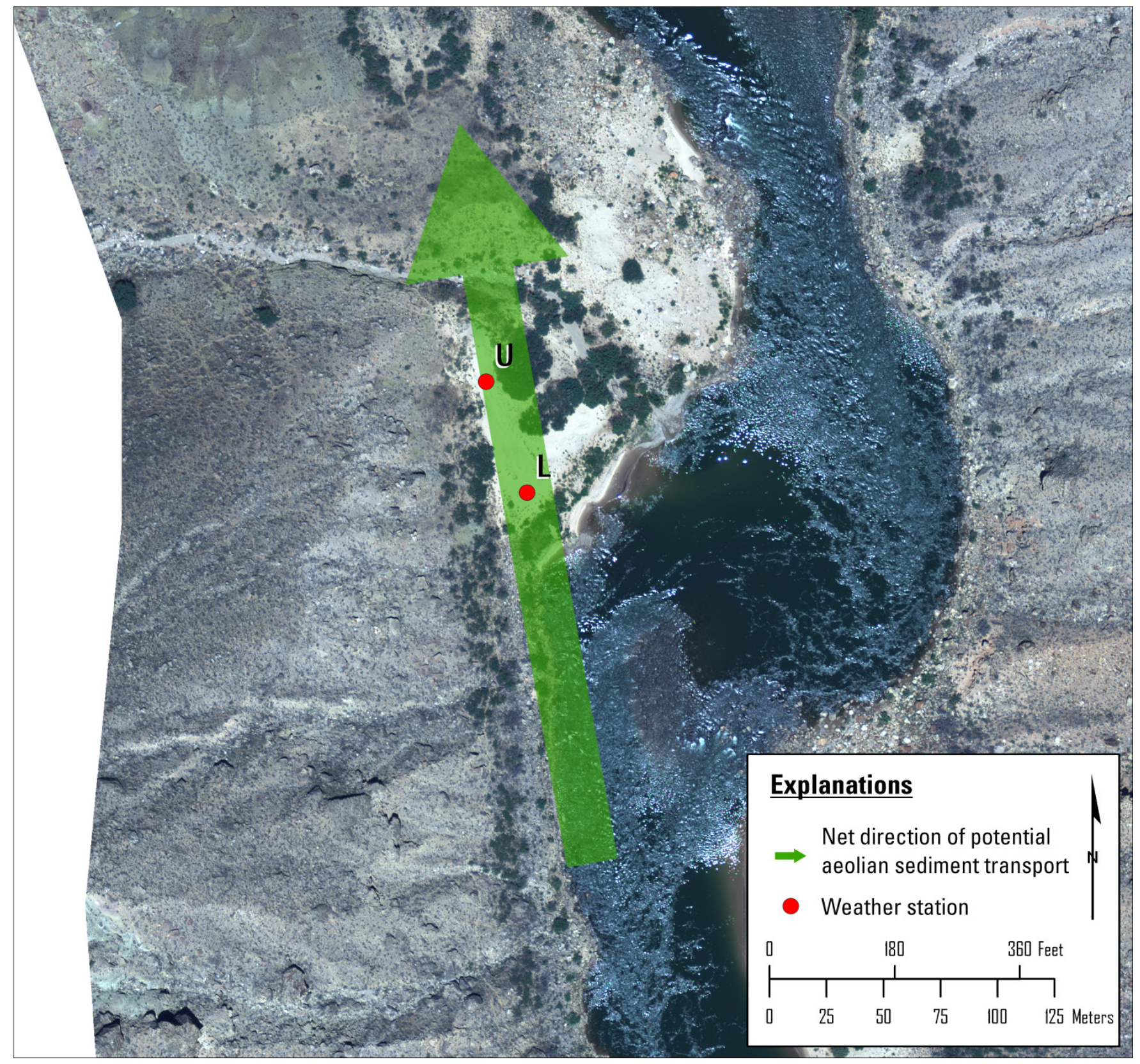

Figure 13. Aerial photograph showing area around site AZ C:13:0365 in Grand Canyon, Arizona. Arrow indicates the net direction of potential aeolian sediment transport measured at AZ C:13:0365 L in 2010. A vector sum of the $Q p$ proxy variable (equation 1), calculated using all the wind data collected during dry conditions from AZ C:13:0365 L in 2010, indicates net sediment transport from $171^{\circ}$. 


\section{Station AZ C:13:0365 L}

4-minute average wind speed, in meters per second and wind direction, in degrees True

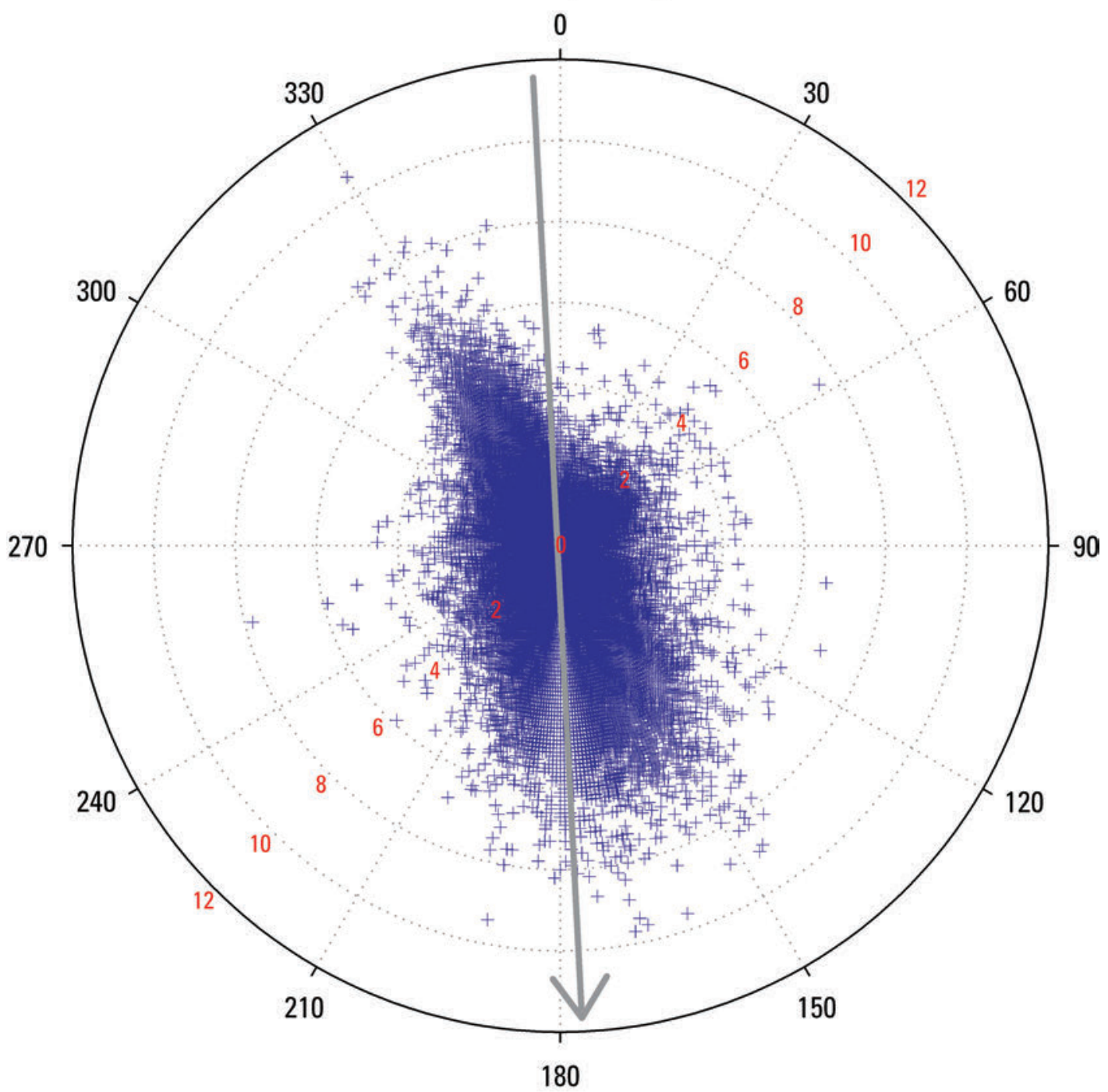

Figure 14. Plot showing magnitude and direction of wind velocity measured at the instrument station $A Z$ C:13:0365 L with 4-minute resolution in Grand Canyon, Arizona, 2010. Magnitude is indicated by the concentric circles, and compass bearing indicates the wind direction. The gray arrow shows the orientation of the river corridor $\left(177^{\circ}\right)$; river flow is toward the south. 


\section{Station AZ C:13:0365 L}

Cumulative rainfall

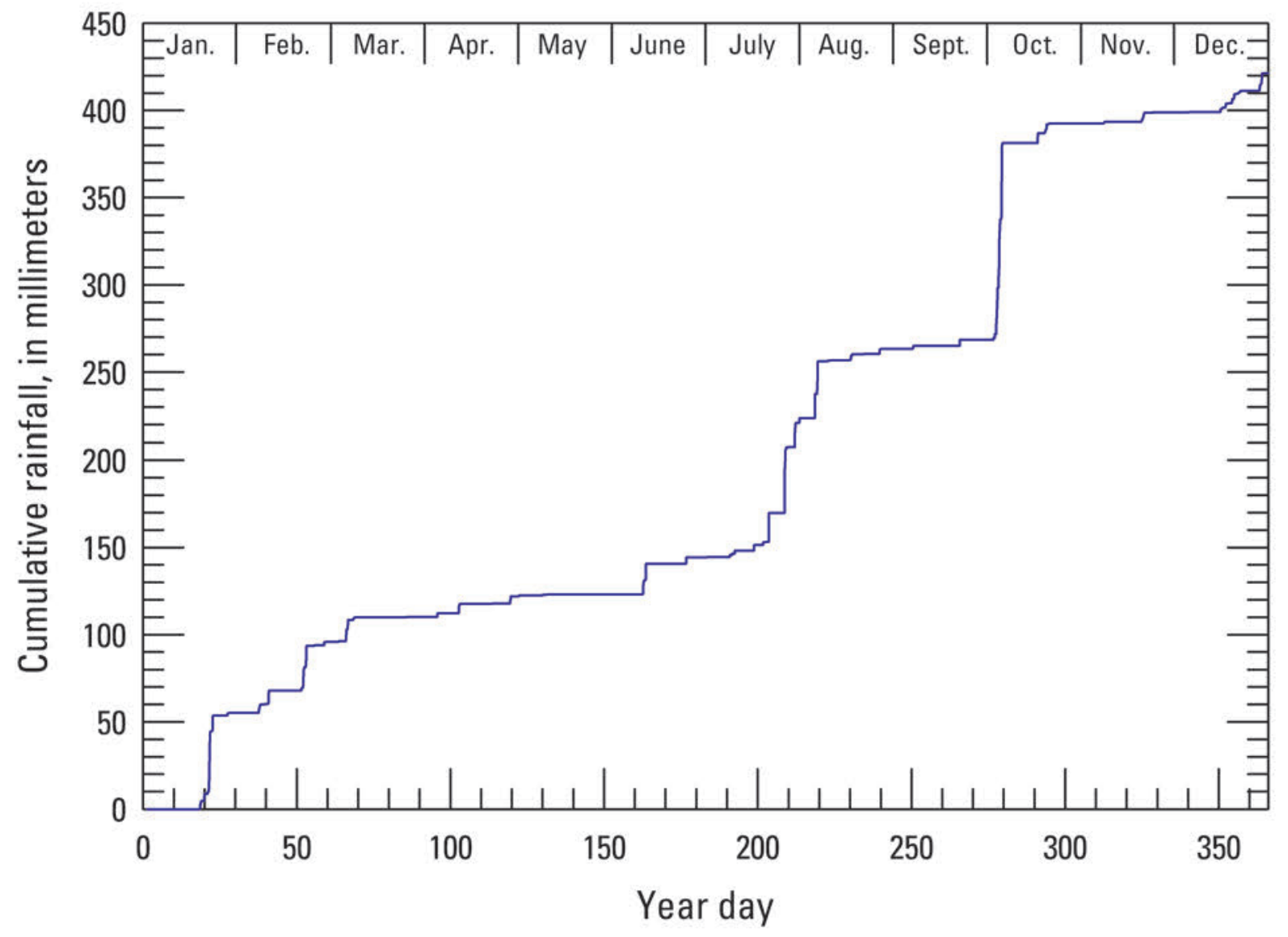

Figure 15. Plot showing cumulative rainfall recorded at station AZ C:13:0365 L compiled from data collected at 4-minute resolution in Grand Canyon, Arizona, 2010. 
2009
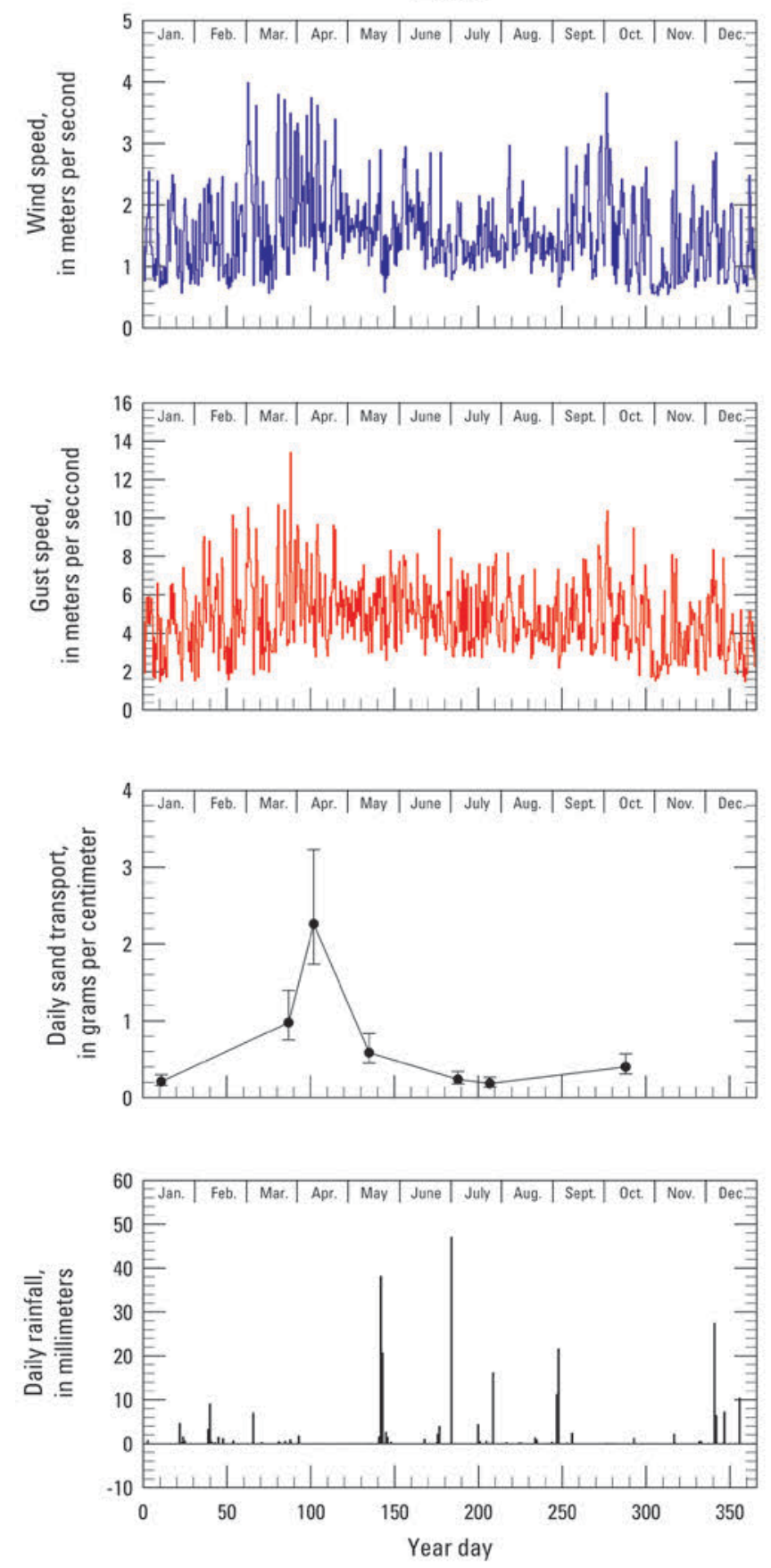

2010
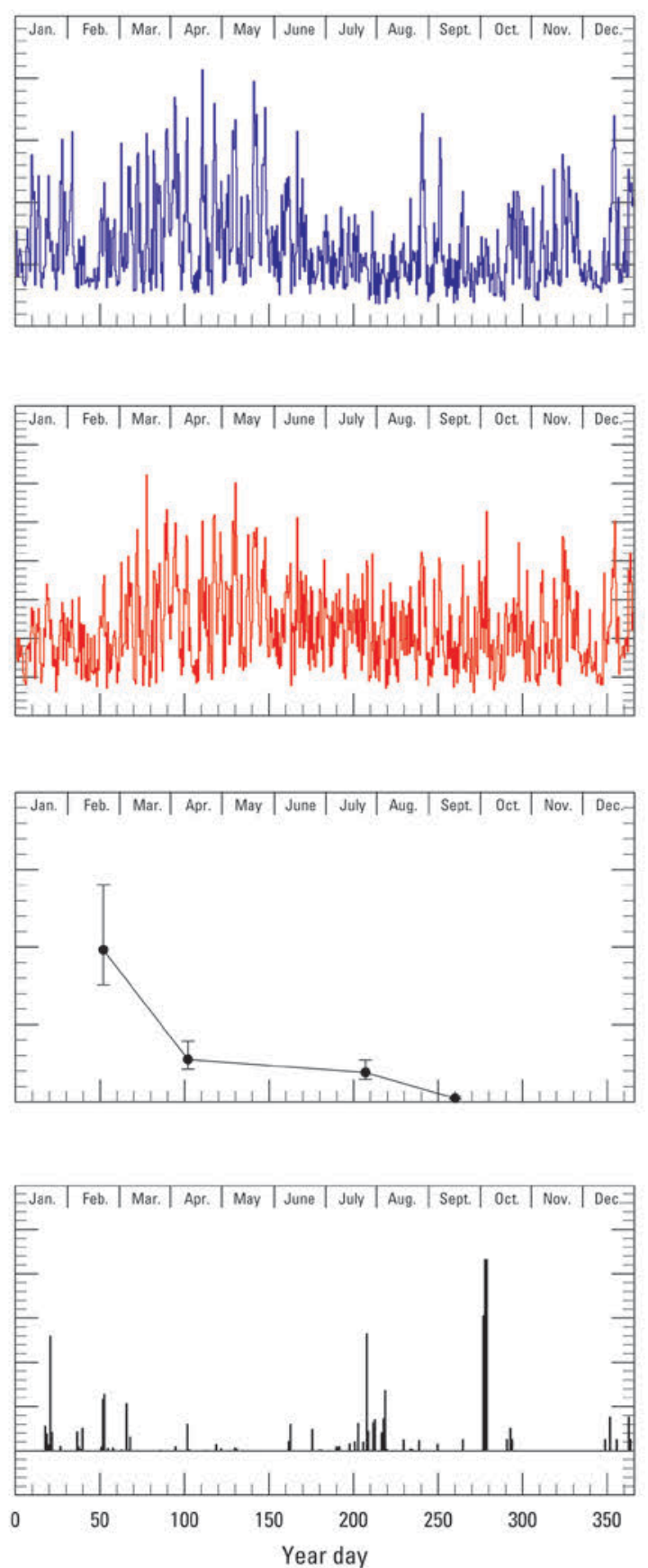

Figure 16. Plots showing wind, aeolian sand-transport, and rainfall data collected at the instrument station AZ C:13:0365 L, in Grand Canyon, Arizona, 2009-10. Wind speed is presented as diurnal average values, using daytime (0600-1800 hours) and nighttime (1800-0600 hours) averages of data collected at 4-minute intervals. Gust speed is shown as maximum values that occurred during each diurnal interval. Daily sand transport is plotted in grams, normalized to a width of 1 centimeter. To obtain these values, total sand mass collected from four traps during each maintenance visit was divided by the number of days since the trap had last been emptied. Rainfall is plotted as daily (24-hour) totals. 

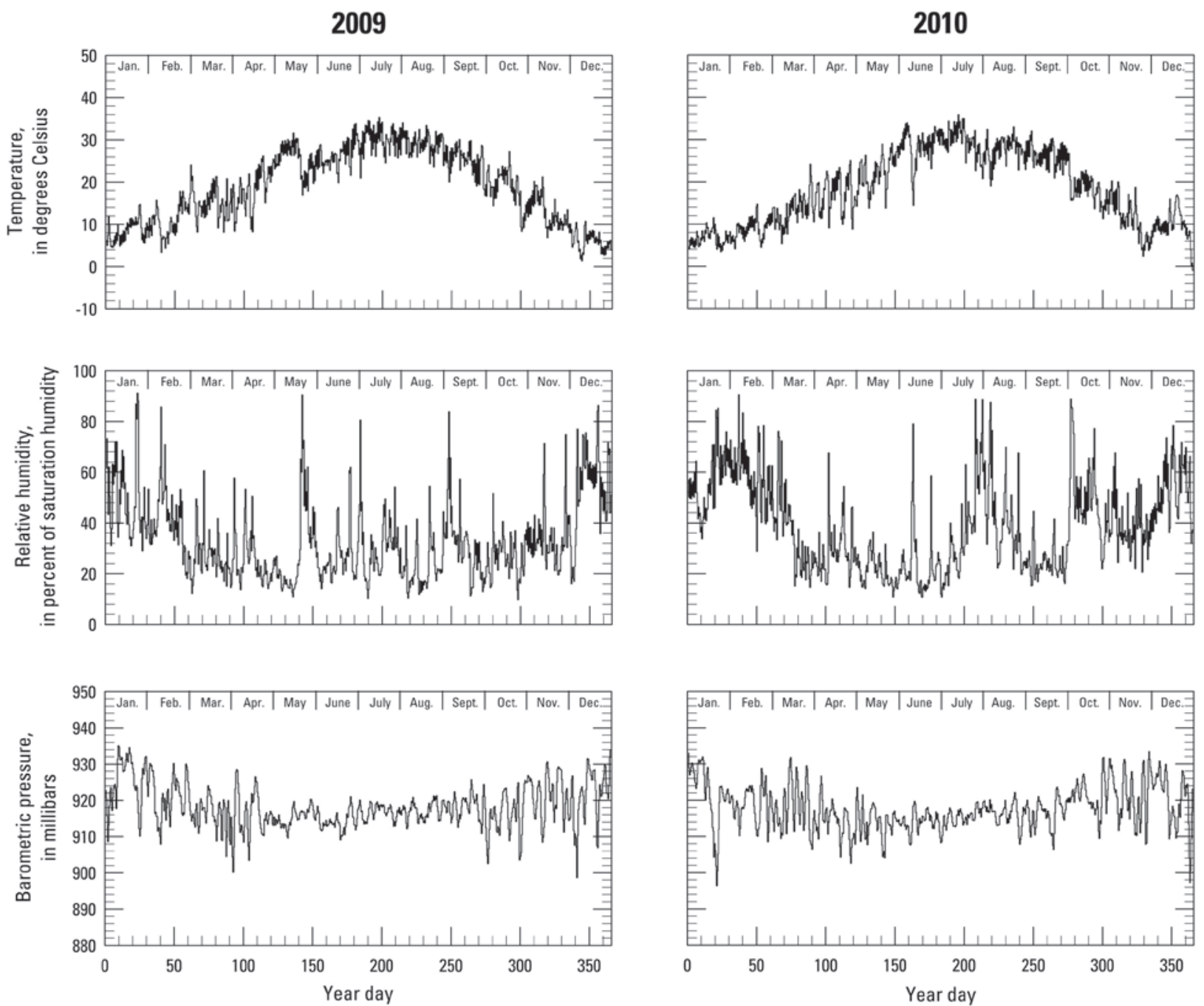

Figure 17. Plots showing temperature, relative humidity, and barometric pressure data collected at instrument station AZ C:13:0365 L, in Grand Canyon, Arizona, 2009-10. All parameters are plotted as diurnal averages (defined using 0600-1800 and 1800-0600 hours). 


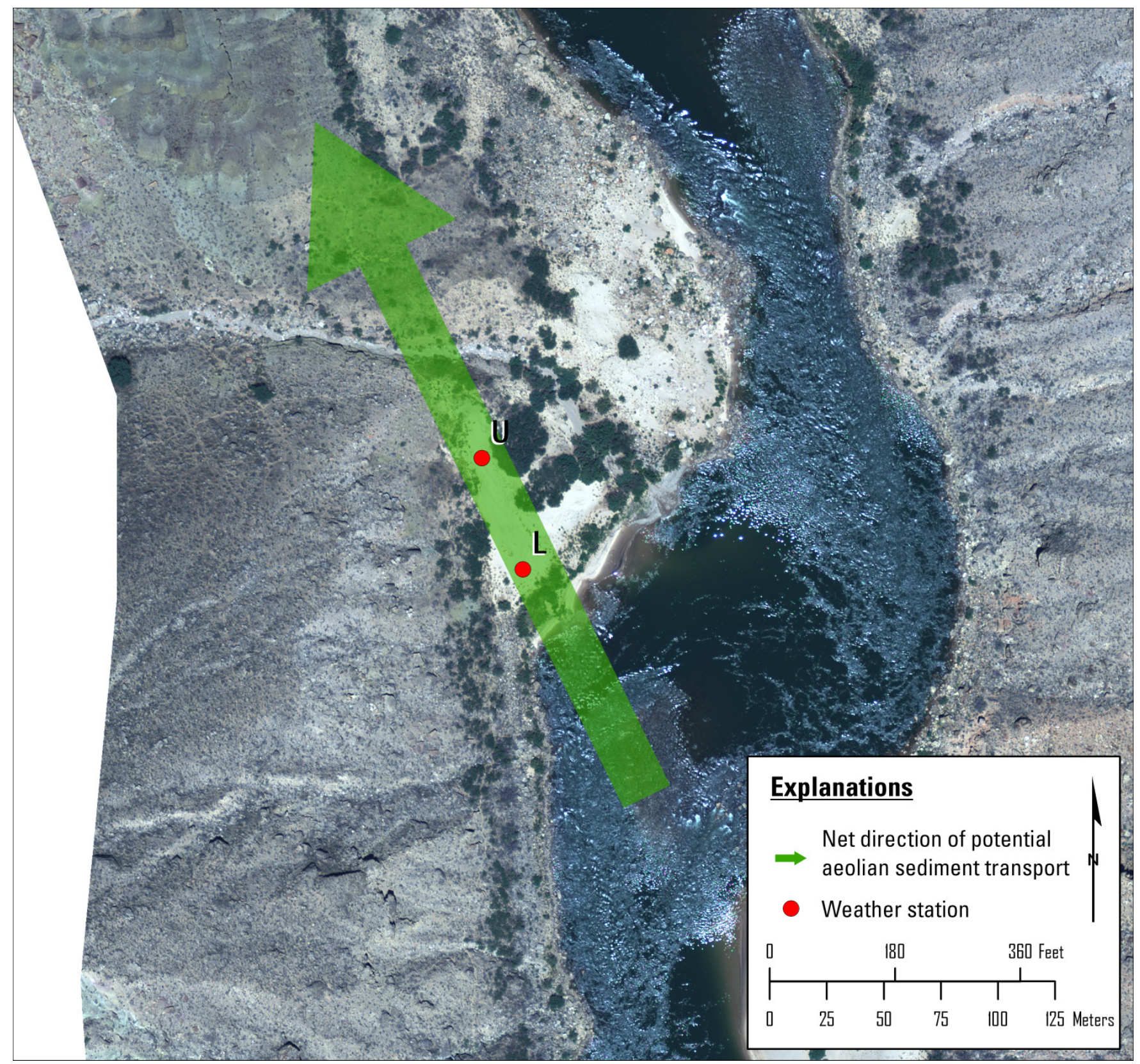

Figure 18. Aerial photograph of the area around site AZ C:13:0365 in Grand Canyon, Arizona. Arrow indicates the net direction of potential aeolian sediment transport measured at AZ C:13:0365 U in 2010. A vector sum of the $Q p$ proxy variable (equation 1 ), calculated using all the wind data collected during dry conditions from AZ C:13:0365 U in 2010, indicates net sediment transport from $154^{\circ}$. 


\section{Station AZ C:13:0365 U}

\section{4-minute average wind speed, in meters per second}

and wind direction, in degrees True

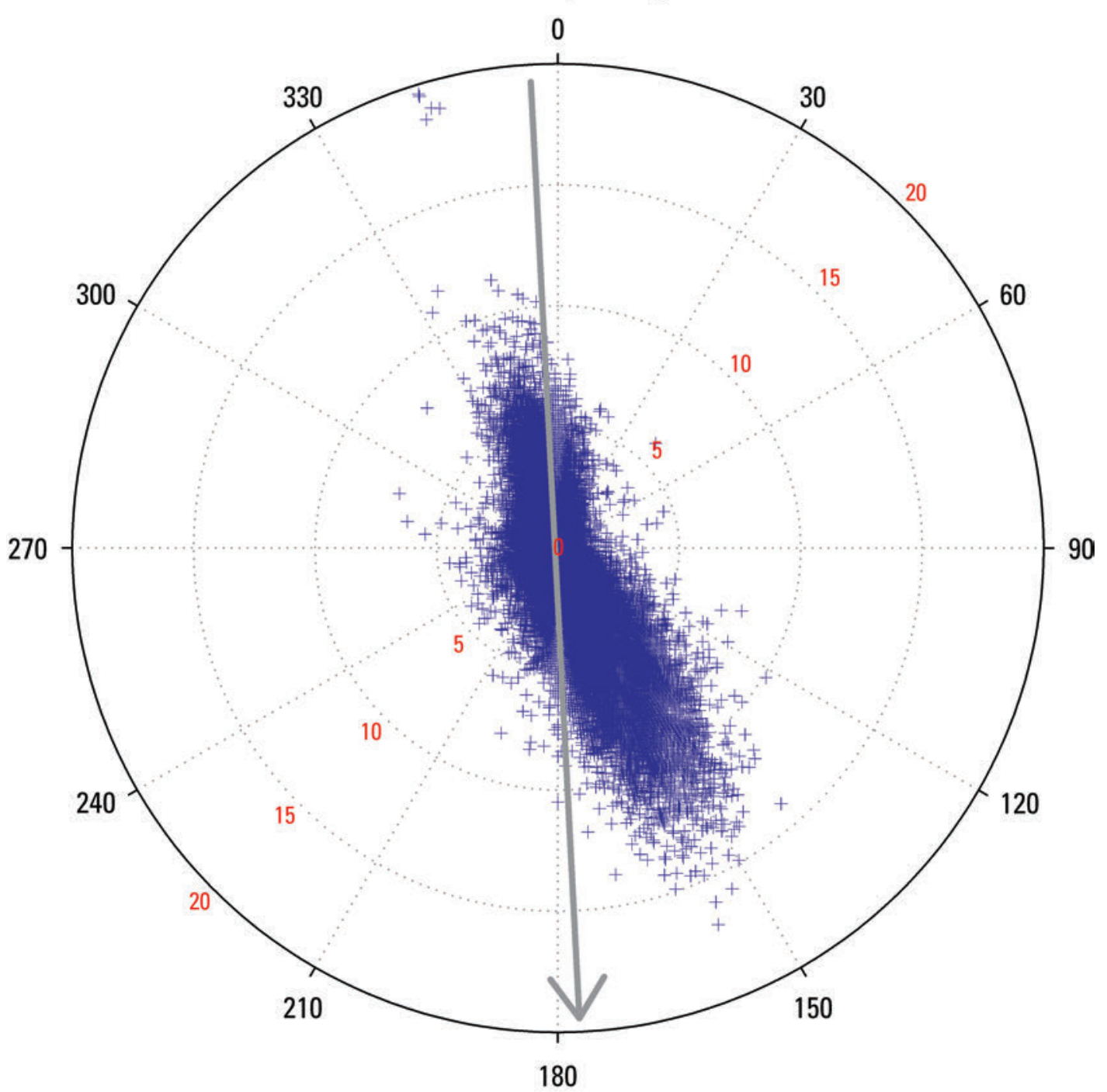

Figure 19. Plot showing magnitude and direction of wind velocity measured at the instrument station $A Z$ C:13:0365 U with 4-minute resolution in Grand Canyon, Arizona, 2010. Magnitude is indicated by the concentric circles, and compass bearing indicates the wind direction. The gray arrow shows the orientation of the river corridor $\left(177^{\circ}\right)$; river flow is toward the south. 


\section{Station AZ C:13:0365 U}

Cumulative rainfall

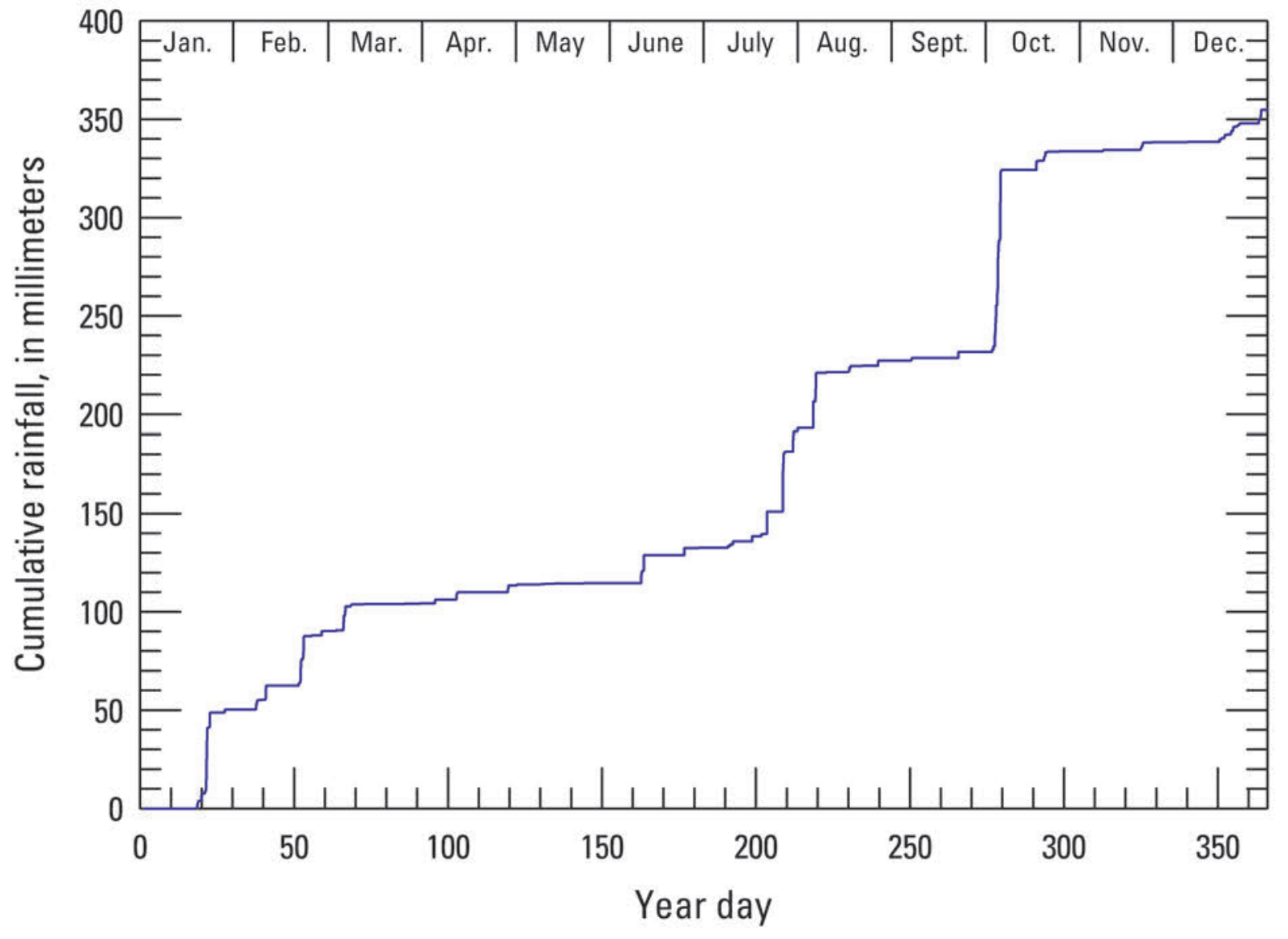

Figure 20. Plot showing cumulative rainfall recorded at station AZ C:13:0365 U compiled from data collected at 4-minute resolution in Grand Canyon, Arizona, 2010. 
2009
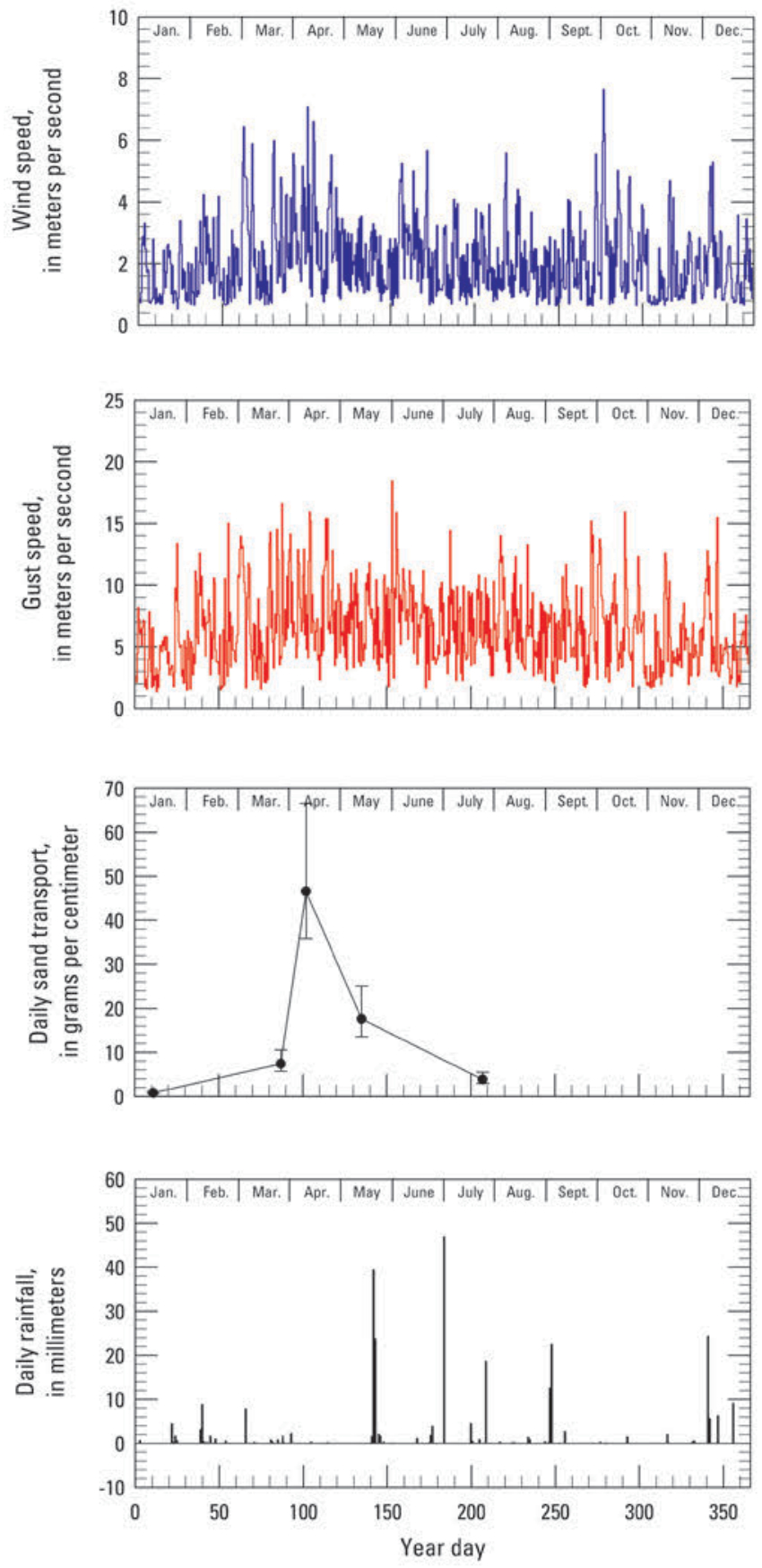

2010
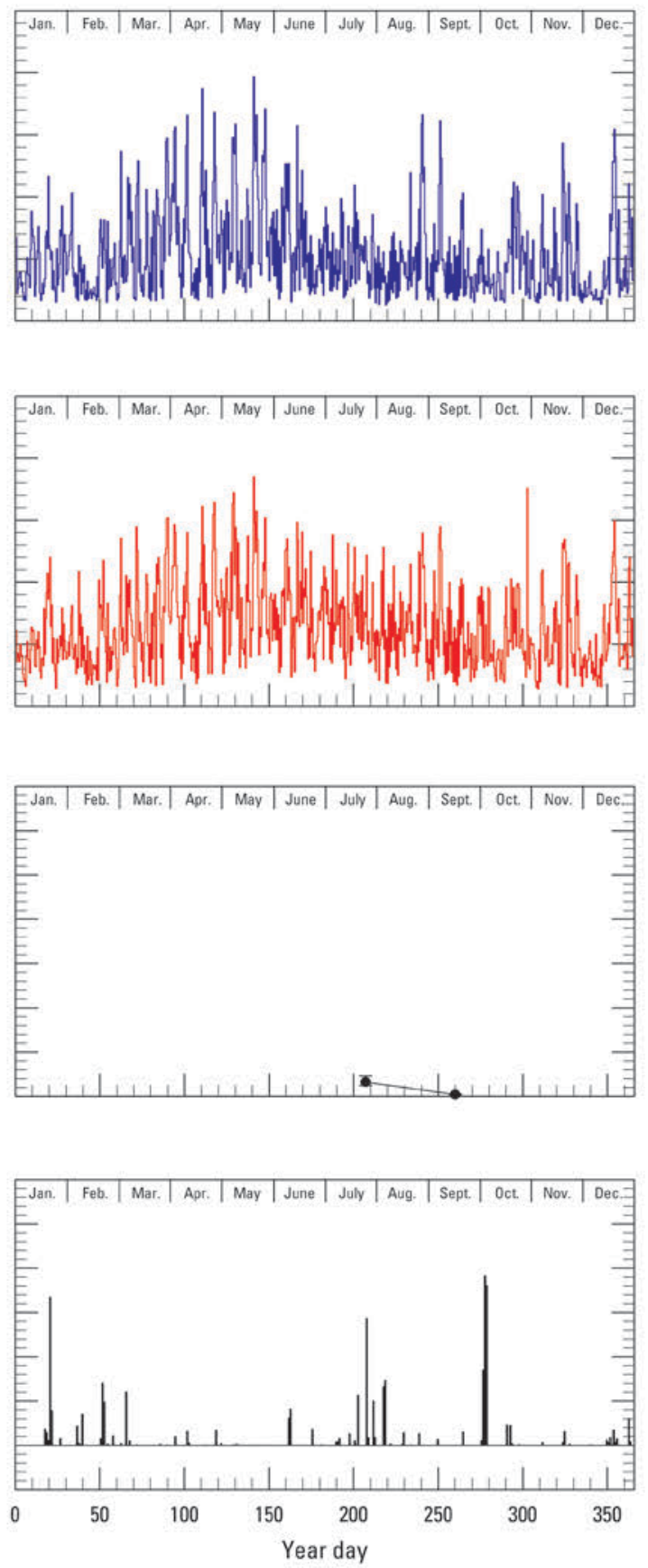

Figure 21. Plots showing wind, aeolian sand-transport, and rainfall data collected at the instrument station AZ C:13:0365 U in Grand Canyon, Arizona, 2009-10. Wind speed (blue plot) is presented as diurnal average values, using daytime (0600-1800 hours) and nighttime (1800-0600 hours) averages of data collected at 4-minute intervals. Gust speed (red plot) is shown as maximum values that occurred during each diurnal interval. Daily sand transport is plotted in grams, normalized to a width of 1 centimeter. To obtain these values, total sand mass collected from four traps during each maintenance visit was divided by the number of days since the trap had last been emptied. Rainfall is plotted as daily (24-hour) totals. 

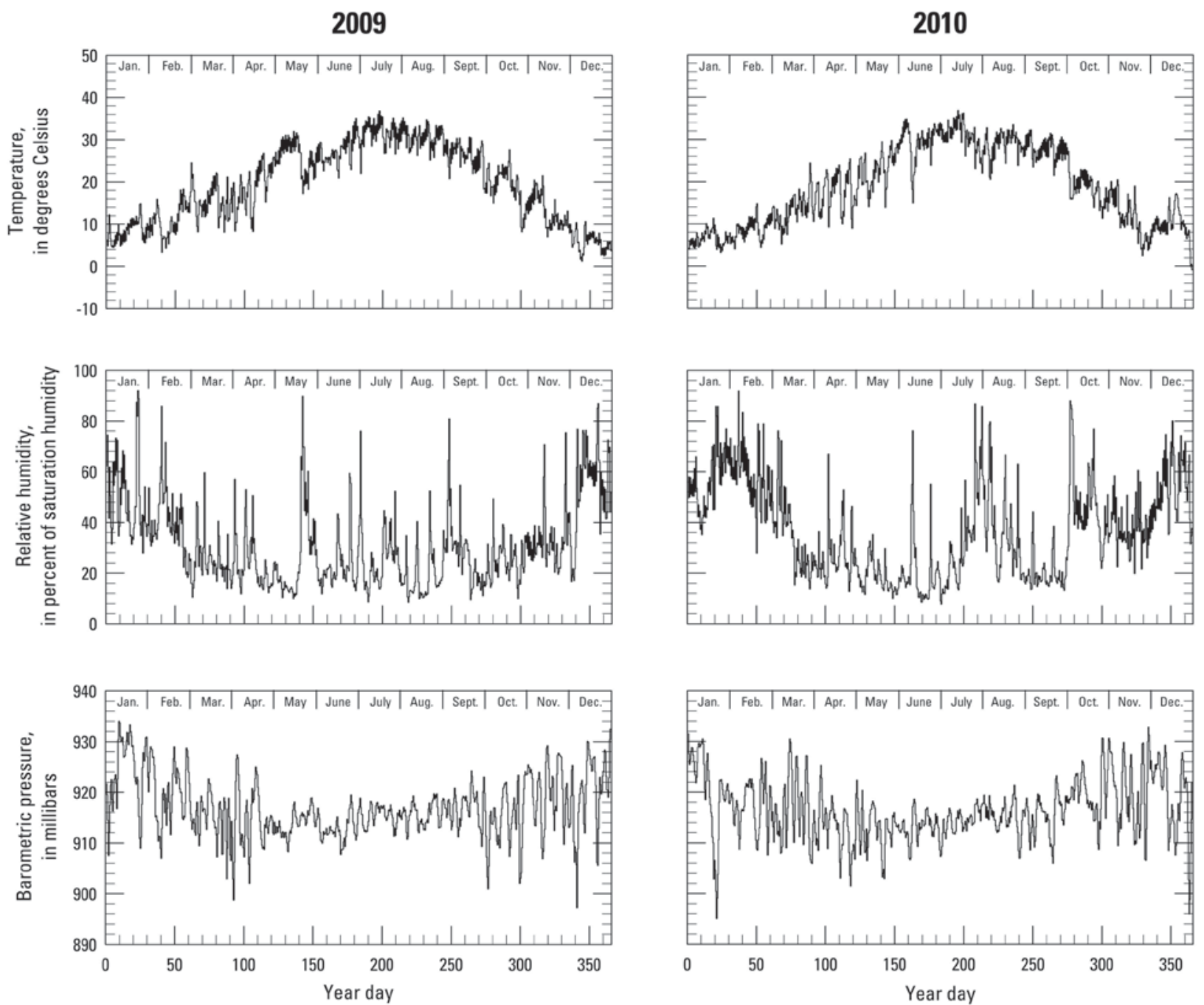

Figure 22. Plots showing temperature, relative humidity, and barometric pressure data collected at instrument station AZ C:13:0365 U in Grand Canyon, Arizona, 2009-10. All parameters are plotted as diurnal averages (defined using 0600-1800 and 1800-0600 hours). 
The instrument station near site AZ C:13:0006 is on the upstream side (with respect to the Colorado River) of an ephemeral tributary streambed on a small debris fan. At the instrument site, aeolian sediment is present but is interspersed with rocks and sparse vegetation; areas of open sediment near the weather station and sand traps are largely covered by well-developed biological soil crust.

A vector sum of all wind data from the weather station at AZ C:13:0006 in 2009 yields a net $Q p$ magnitude of $100,400 \mathrm{~m}^{3} / \mathrm{s}^{3}$ from a direction of $131^{\circ}$; using data only from when the sand is estimated to have been dry, a vector sum yields a net $Q p$ magnitude of $63,431 \mathrm{~m}^{3} / \mathrm{s}^{3}$ from a direction of $129^{\circ}$ (table 3). These calculations indicate net sand transport generally toward upstream (fig. 23). Wind speed and direction measured at site AZ C:13:0006 in 2010 are plotted in figure 24. Cumulative rainfall data are shown in figure 25; the 2010 annual rainfall total at this site was $360.1 \mathrm{~mm}$ (table 2). All weather parameters and sand transport measured at site AZ C:13:0006 in 2010 are summarized in figures 26 and 27.

Although wind from other directions is not uncommon around site AZ C:13:0006 (fig. 24), net potential sediment transport from the east-southeast was indicated during 2010, similar to conditions measured at this site between 2007 and 2009 (Draut and others, 2009a, 2009b). Net sand transport from the southeast would be consistent with the fluvial sand deposit at the downstream end of the debris fan serving as a possible source of windblown sand (fig. 24); however, sand-transport rates measured in 2010 were no higher than in 2007-2009 and, even after the 2008 HFE, these rates remain substantially lower than in more active dune fields such as that at site AZ C:13:0365, with the measured daily flux at site AZ C:13:0006 consistently less than $0.1 \mathrm{~g} / \mathrm{cm}$ (fig. 26). As discussed by Draut and others (2009b), the low sand-transport rates measured at the instrument station (approximately $20 \mathrm{~m}$ laterally away from and $5 \mathrm{~m}$ vertically below the archeological site) likely do not accurately represent aeolian processes acting on the cultural site. However, in order to avoid disturbing the archeological site, sand traps cannot be deployed directly in the area where Collins and others (2009) used remote-sensing lidar equipment to record aeolian sand deposition at site AZ C:13:0006. Therefore, links among HFE sand deposition, aeolian sand transport, and inflation-deflation at archeological site AZ C:13:0006 may not be characterized accurately using the data collected by this study. It is likely that a large part, perhaps even most, of the windblown sand moving upstream (north-northwest) from the fluvial deposit at the downstream side of this debris fan is trapped by the tributary channel and does not travel as far as the archaeological site or the AZ C:13:0006 weather station. 


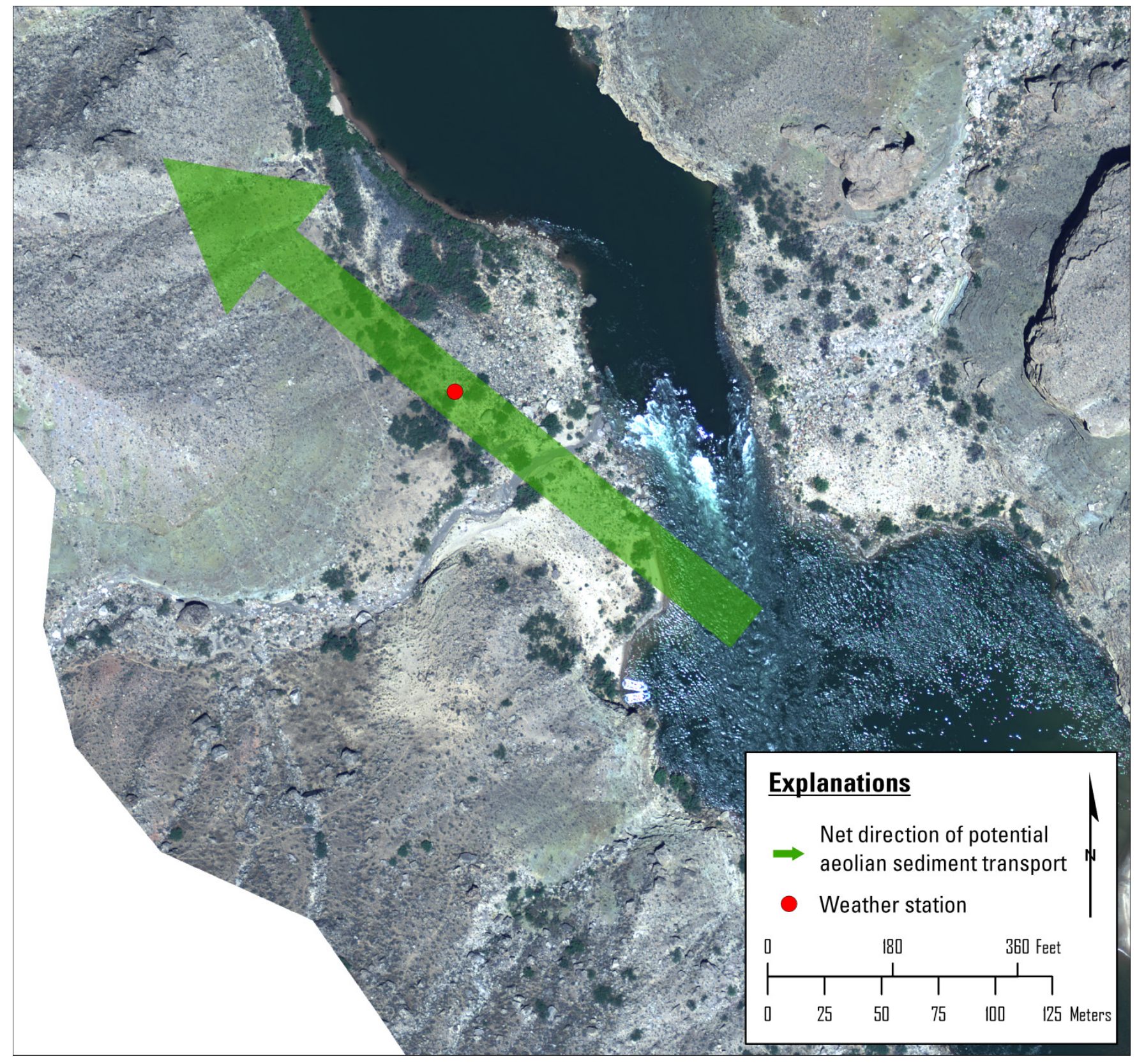

Figure 23. Aerial photograph of the area around site AZ C:13:0006 in Grand Canyon, Arizona. Arrow indicates the net direction of potential aeolian sediment transport measured at AZ C:13:0006 in 2010. A vector sum of the $Q p$ proxy variable (equation 1), calculated using all the wind data collected during dry conditions from AZ C:13:0006 in 2010, indicates net sediment transport from $131^{\circ}$. 


\section{Station AZ C:13:0006}

\section{4-minute average wind speed, in meters per second and wind direction, in degrees True}

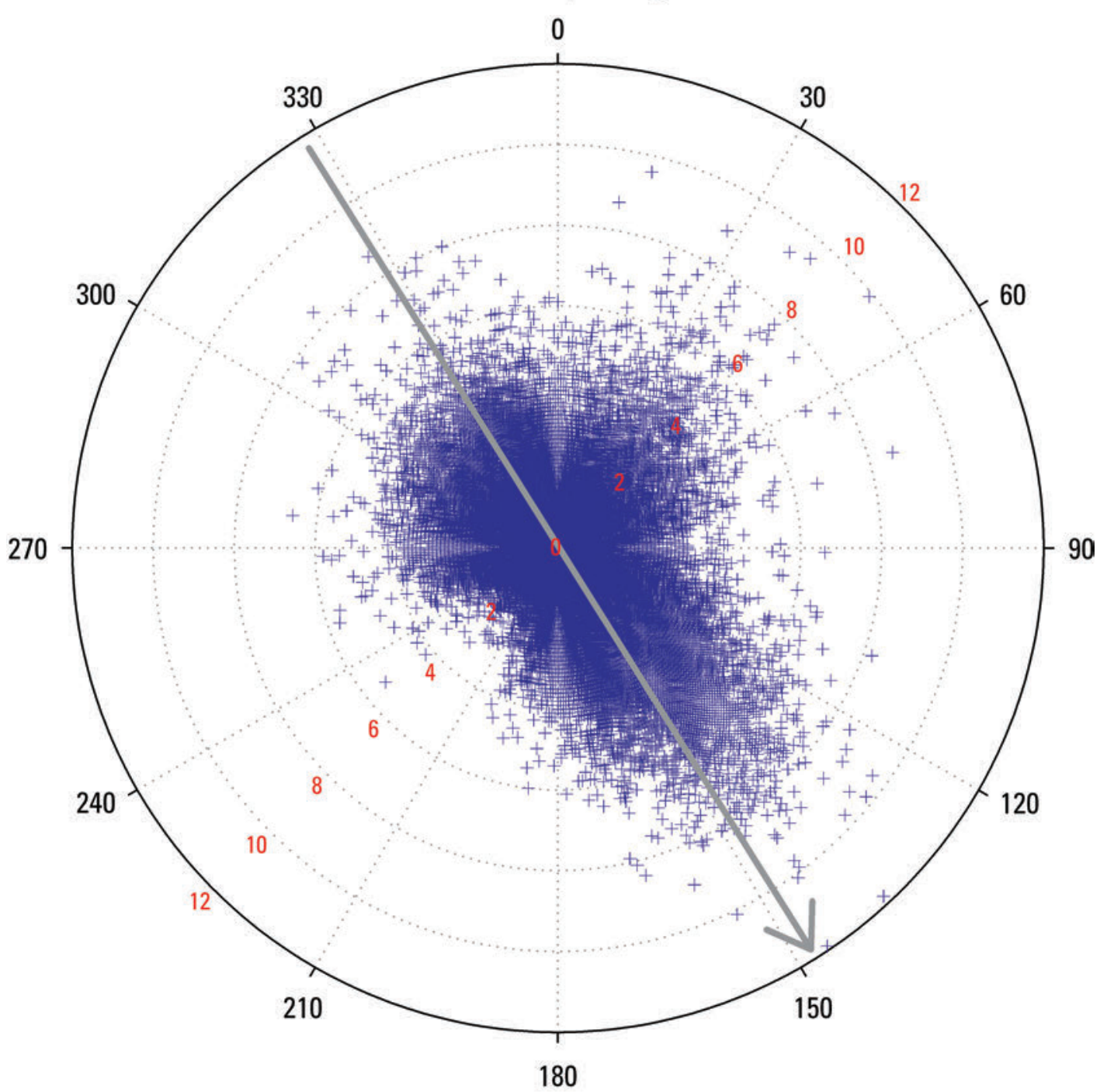

Figure 24. Plot showing magnitude and direction of wind velocity measured at the instrument station AZ C:13:0006 with 4-minute resolution in Grand Canyon, Arizona, 2010. Magnitude is indicated by the concentric circles, and compass bearing indicates the wind direction. The gray arrow shows the orientation of the river corridor $\left(148^{\circ}\right)$; river flow is toward the south. 


\section{STATION AZ C:13:0006}

Cumulative rainfall

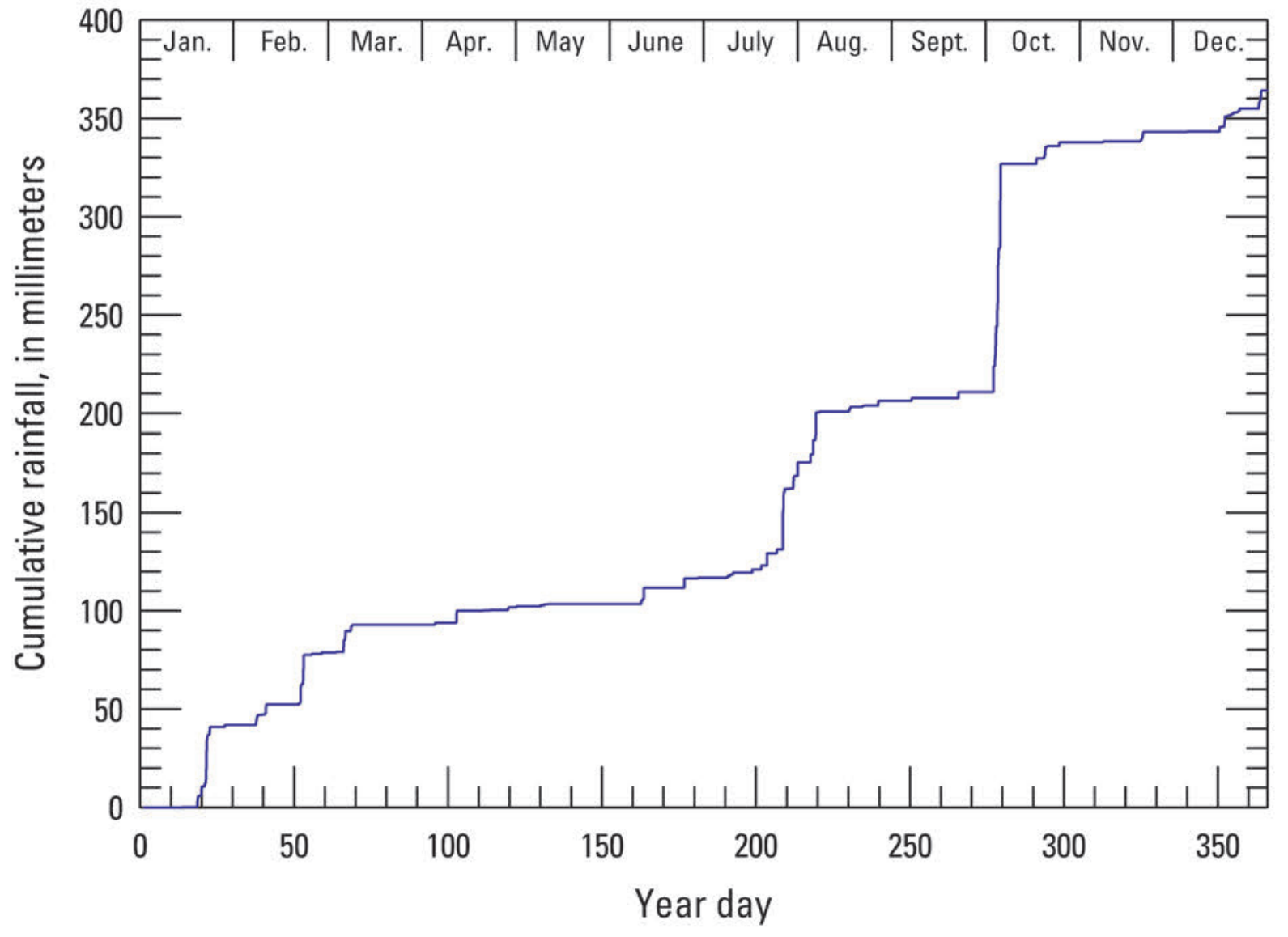

Figure 25. Plot showing cumulative rainfall recorded at site AZ C:13:0006 compiled from data collected at 4minute resolution in Grand Canyon, Arizona, 2010. 
The Palisades area in eastern Grand Canyon is near the start of a relatively open stretch of the river corridor that is referred to as the Furnace Flats by Schmidt and Graf (1990). The local area is characterized by alluvial terraces capped by aeolian coppice dunes that are vegetated by grasses and small mesquite trees. The alluvial deposits in the immediate vicinity of this site represent multiple episodes of floodplain aggradation by Colorado River floods that predate the completion of Glen Canyon Dam in 1963 (Hereford and others, 1993, 1996; Draut and others, 2008). Aeolian coppice dunes at Palisades were interpreted by Hereford and others (1993) and Draut and Rubin (2008) as relict fluvial sourced (RFS) aeolian deposits that formed by in-place reworking of older flood sediment, rather than having been recently sourced from river-level sandbars within the normal dam-controlled flow range. Alluvial and aeolian deposits are incised by a major gully network that drains to the river (Hereford and others, 1993; Thompson and Potochnik, 2000; Hazel and others, 2008). Repeated topographic surveys have shown frequent changes in gully geometry at Palisades, including aggradation in its mouth as a result of HFEs in 1996 and 2004 and episodic erosion attributed to rain events (Yeatts, 1996; Hazel and others, 2008). The sandbar nearest to site AZ C:13:0336 increased substantially in area and volume as a result of the March 2008 HFE (Draut and others, 2009b). Although subsequent flow fluctuations caused cutbank retreat that eroded the sandbar through the latter part of 2008 (Draut and others, 2009b), by mid-2010 a substantial sandbar was still present and was being colonized by tamarisk and other vegetation.

One weather station and one set of sand traps operate at station AZ C:13:0336 U (fig. 28). Since February 2008, one additional set of sand traps has collected windblown sand at a site referred to as AZ C:13:0336 L, on a cobble bar riverward of AZ C:13:0336 U (fig. 28). The AZ C:13:0336 L study site is approximately $50 \mathrm{~m}$ upstream of where a single set of sand traps was used by Draut and Rubin (2008) to study sand transport near river level following the $2004 \mathrm{HFE}$.

Wind speed and direction measured at station AZ C:13:0336 U in 2010 are plotted in figure 29. Cumulative rainfall data are shown in figure 30. The 2010 annual rainfall total at this site was $325.8 \mathrm{~mm}$ (table 2). All weather parameters and sand transport measured at station AZ C:13:0336 U, and sand transport measured at station AZ C:13:0336 L, in 2010 are summarized in figures 31 and 32, with 2009 data shown for comparison.

Net potential sediment transport from the southeast was indicated at station AZ C:13:0336 U during 2010 (fig. 28), similar to conditions measured at this site in previous years (Draut and Rubin, 2008; Draut and others, 2009a, 2009b). A vector sum of wind data from the weather station at AZ C:13:0336 U in 2010 yields a net $Q p$ magnitude of $907,640 \mathrm{~m}^{3} / \mathrm{s}^{3}$ from a direction of $148^{\circ}$; using wind data collected only when the sand is estimated to have been dry, a vector sum yields a net $Q p$ magnitude of $533,990 \mathrm{~m}^{3} / \mathrm{s}^{3}$ from a direction of $147^{\circ}$ (table 3). The highest wind speeds in 2010 were observed later (April-May) than in 2009; in 2009, the windiest season was uncharacteristically early and spanned March-April (by visual inspection of 4-minute-averaged wind-speed data; fig. 31). Sand-transport rates measured at station AZ C:13:0336 U in 2010 were limited in scope, owing to sand-trap malfunction, and cannot be compared directly with those measured in 2009. Sediment-transport rates measured on the cobble bar near river level (station AZ C:13:0336 L) generally were less than one-twentieth as great as those within the dune field (station AZ C:13:0336 U; fig. 31). 
2009
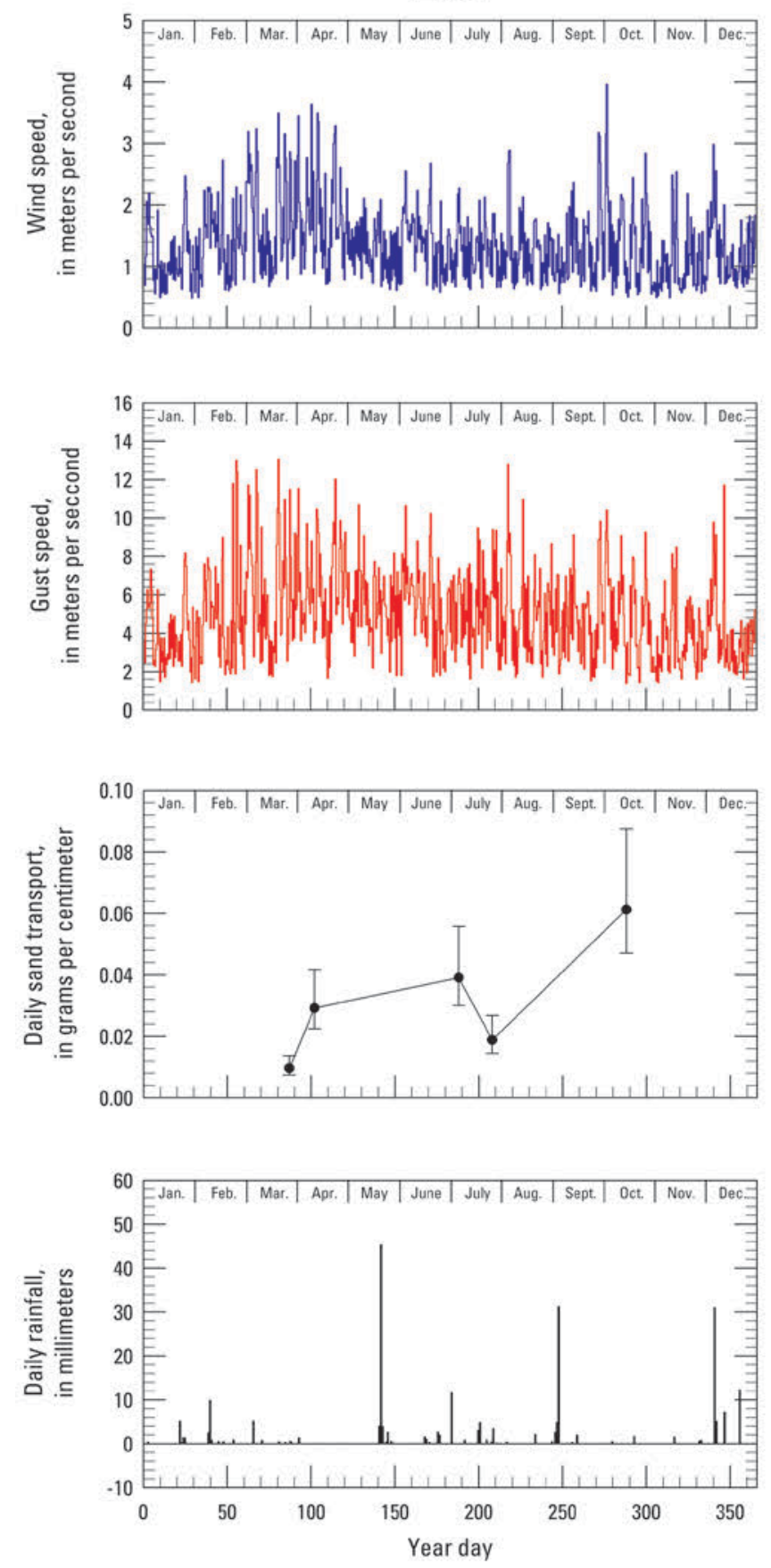

2010
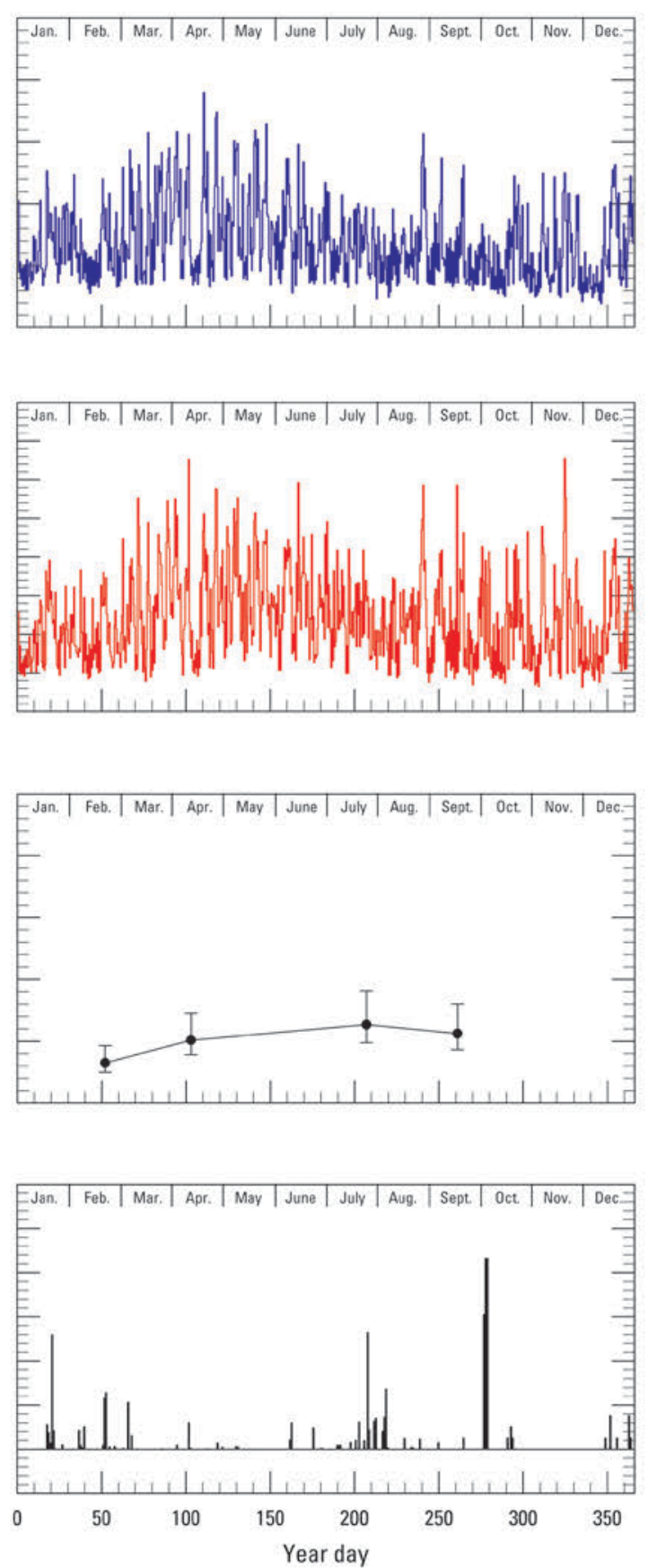

Figure 26. Plots showing wind, aeolian sand-transport, and rainfall data collected at the instrument station AZ C:13:0006 in Grand Canyon, Arizona, 2009-10. Wind speed is presented as diurnal average values, using daytime (0600-1800 hours) and nighttime (1800-0600 hours) averages of data collected at 4-minute intervals. Gust speed is shown as maximum values that occurred during each diurnal interval. Daily sand transport is plotted in grams, normalized to a width of 1 centimeter. To obtain these values, total sand mass collected from four traps during each maintenance visit was divided by the number of days since the trap had last been emptied. Rainfall is plotted as daily (24-hour) totals. 

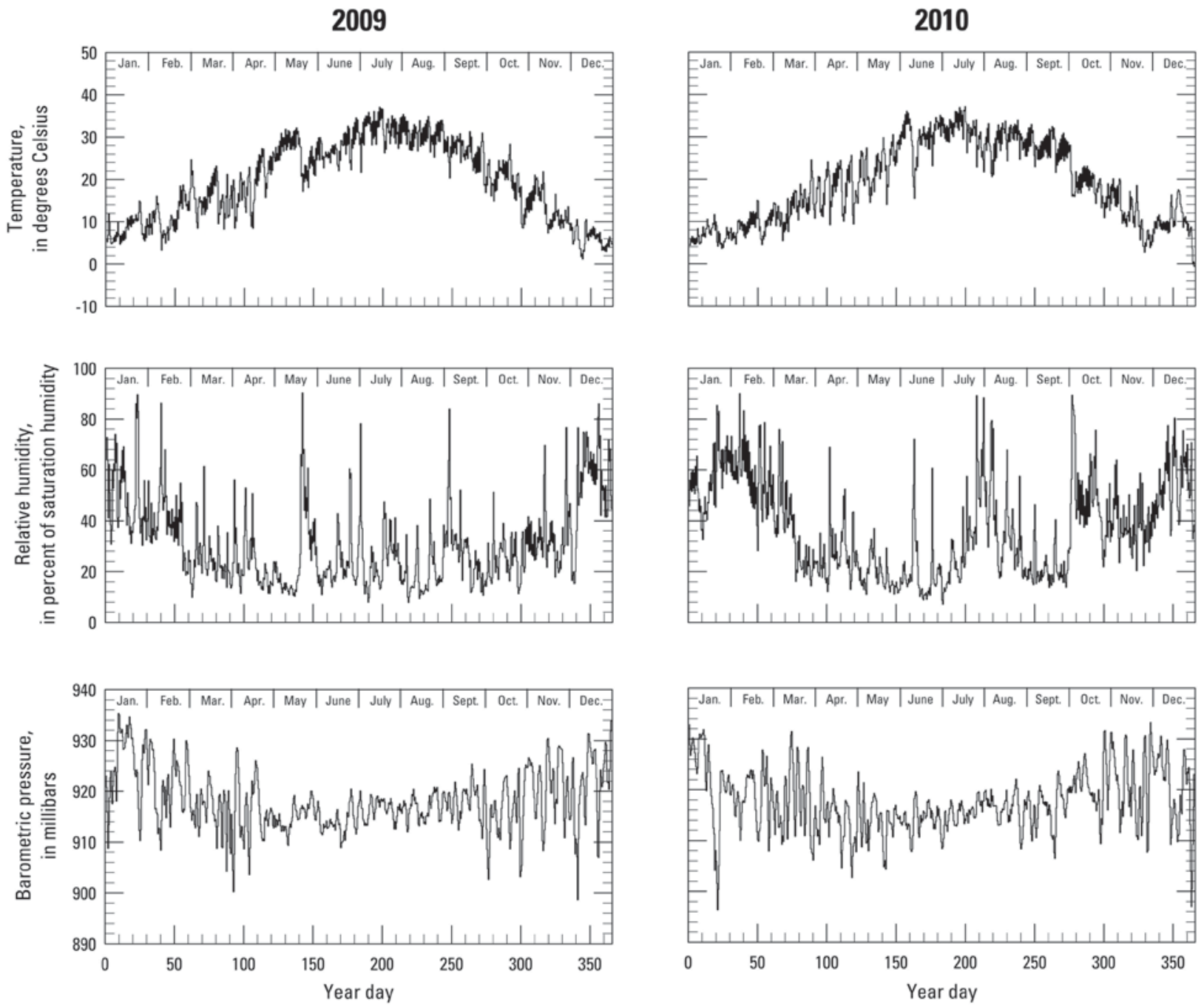

Figure 27. Plots showing temperature, relative humidity, and barometric pressure data collected at instrument station AZ C:13:0006 in Grand Canyon, Arizona, 2009-10. All parameters are plotted as diurnal averages (defined using 0600-1800 and 1800-0600 hours). 


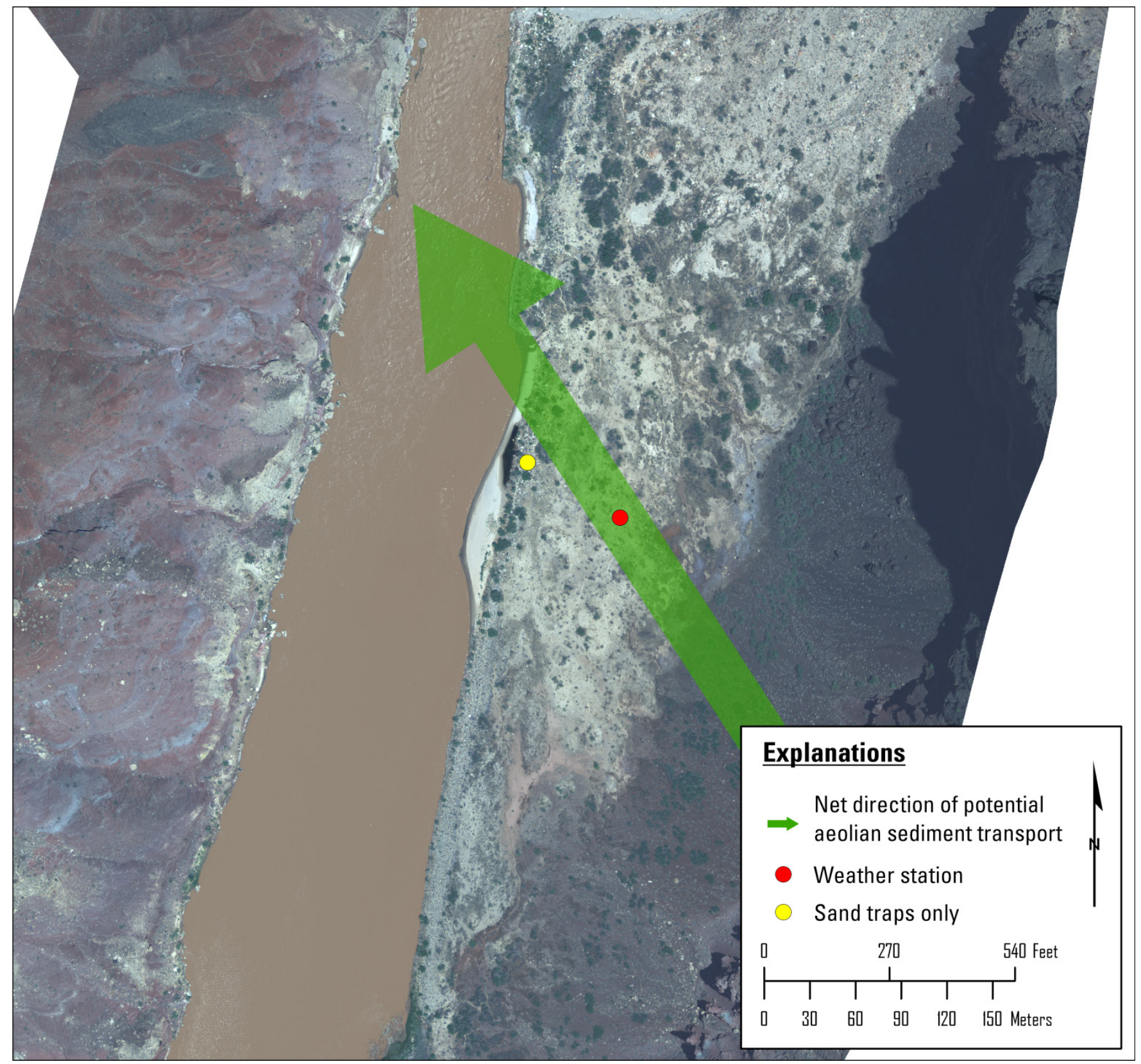

Figure 28. Aerial photograph of the area around site AZ C:13:0336 in Grand Canyon, Arizona. Red dot designates AZ C:13:0336 U, and yellow designates AZ C:13:0336. Arrow indicates the net direction of potential aeolian sediment transport measured at AZ C:13:0336 U in 2010. A vector sum of the $Q p$ proxy variable (equation 1), calculated using all the wind data collected during dry conditions from station $A Z C: 13: 0336 U$ in 2010 , indicates net sediment transport from $148^{\circ}$. 


\section{Station AZ C:13:0336 U}

4-minute average wind speed, in meters per second and wind direction, in degrees True

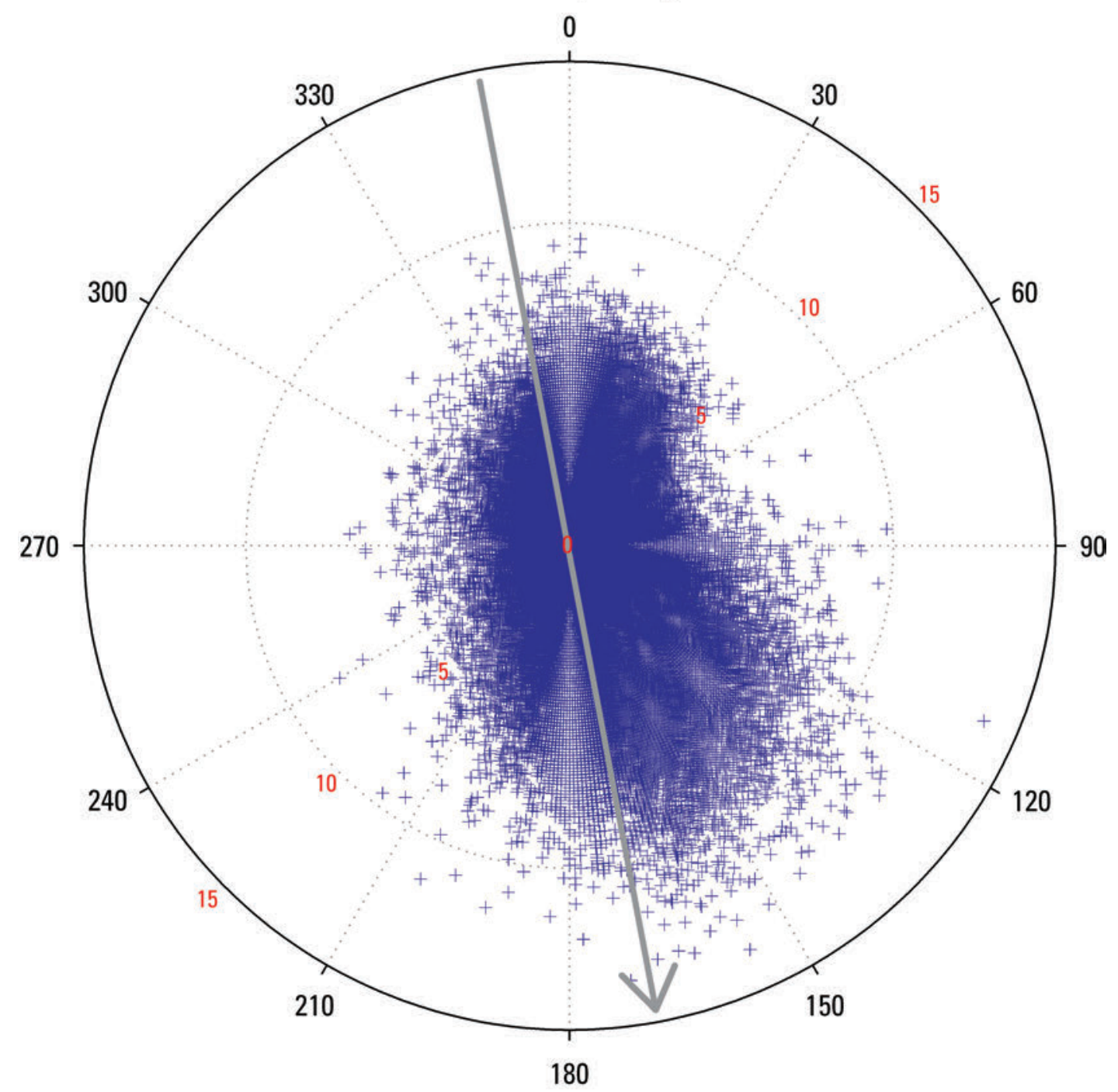

Figure 29. Plot showing magnitude and direction of wind velocity measured at the instrument station AZ C:13:0336 U with 4-minute resolution in Grand Canyon, Arizona, 2010. Magnitude is indicated by the concentric circles, and compass bearing indicates the wind direction. The gray arrow shows the orientation of the river corridor $\left(169^{\circ}\right)$; river flow is toward the south. 


\section{Station AZ C:13:0336 U}

Cumulative rainfall

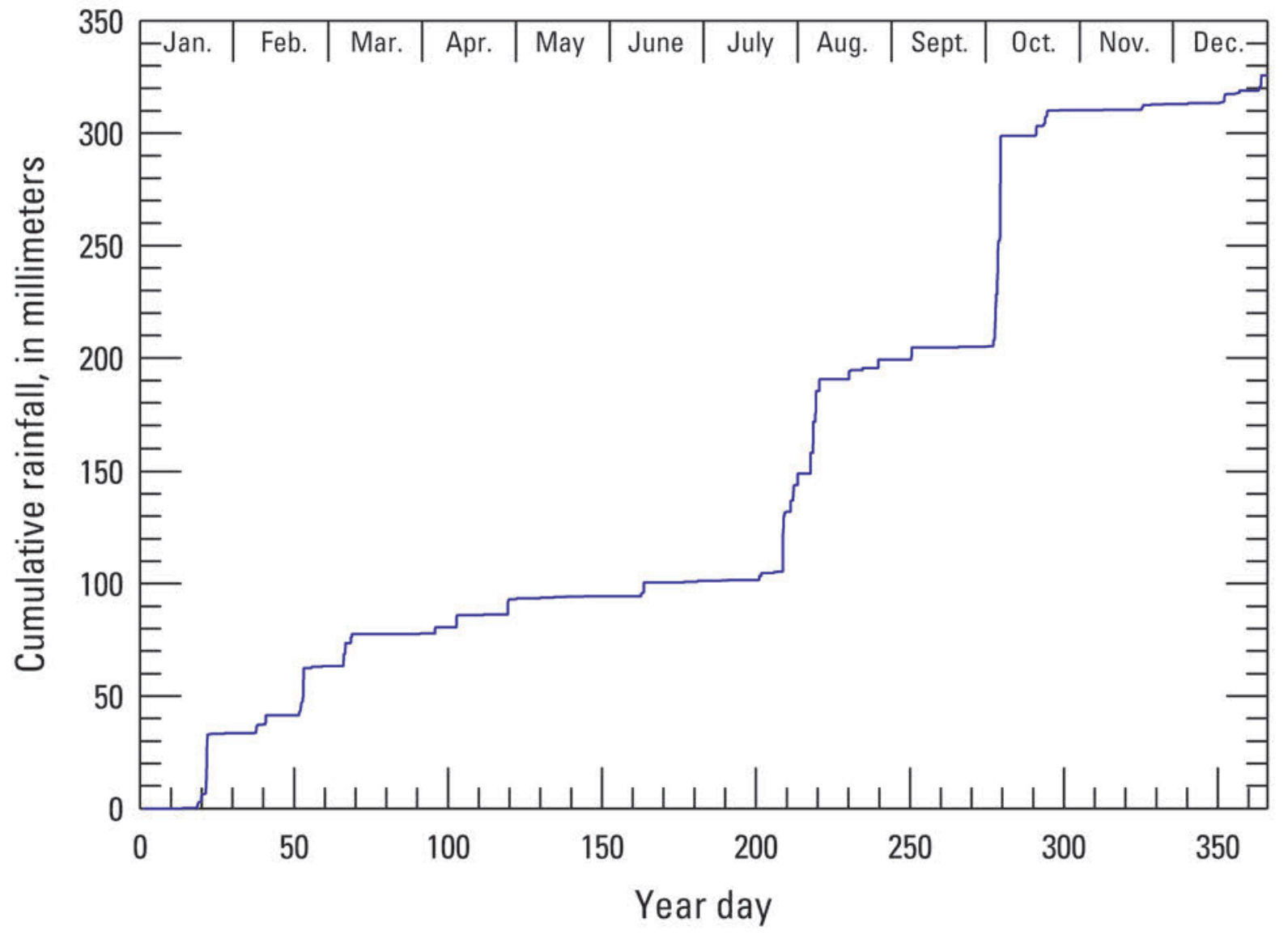

Figure 30. Plot showing cumulative rainfall recorded at station AZ C:13:0336 U compiled from data collected at 4-minute resolution in Grand Canyon, Arizona, 2010. 
2009
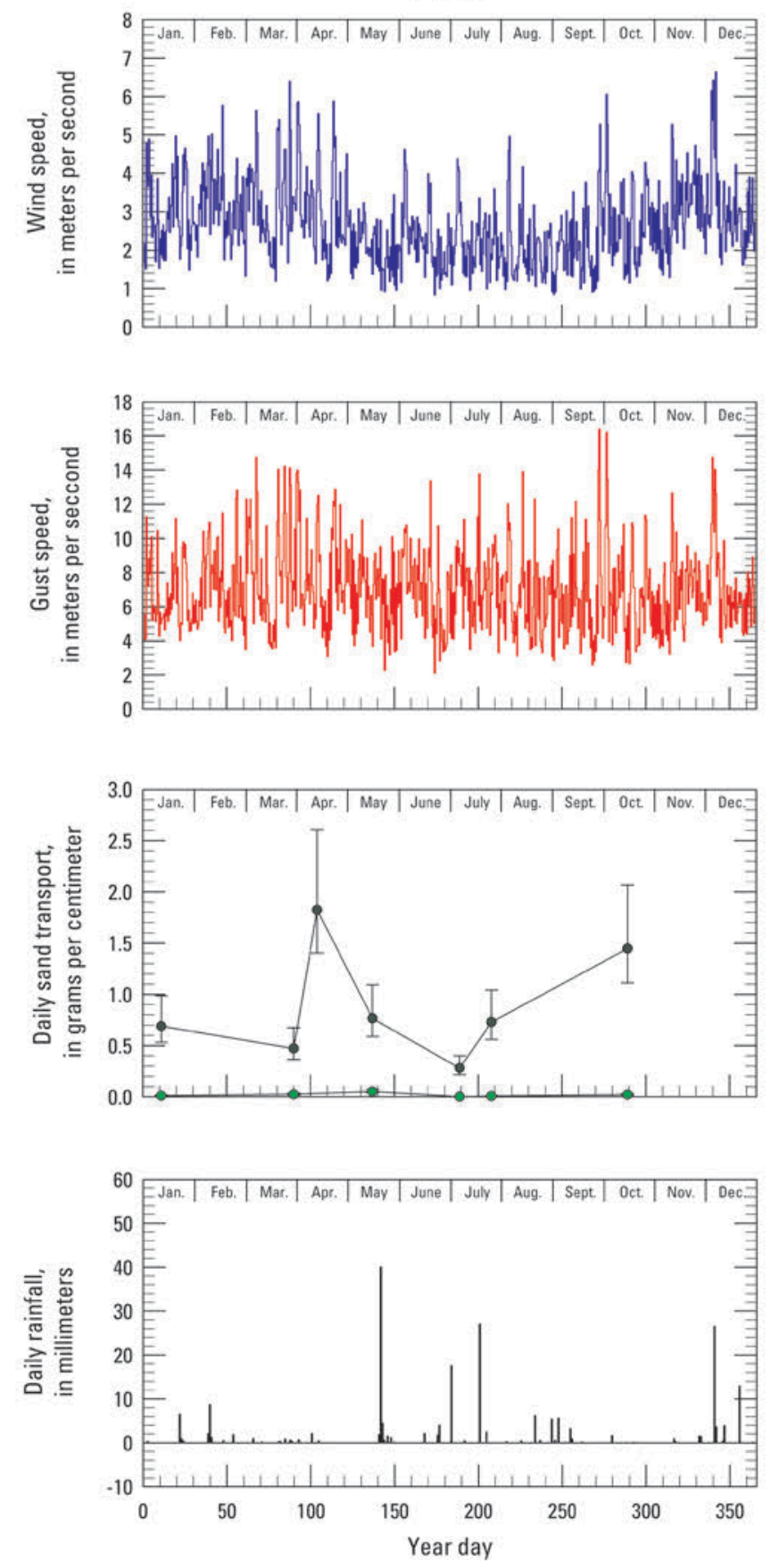

2010
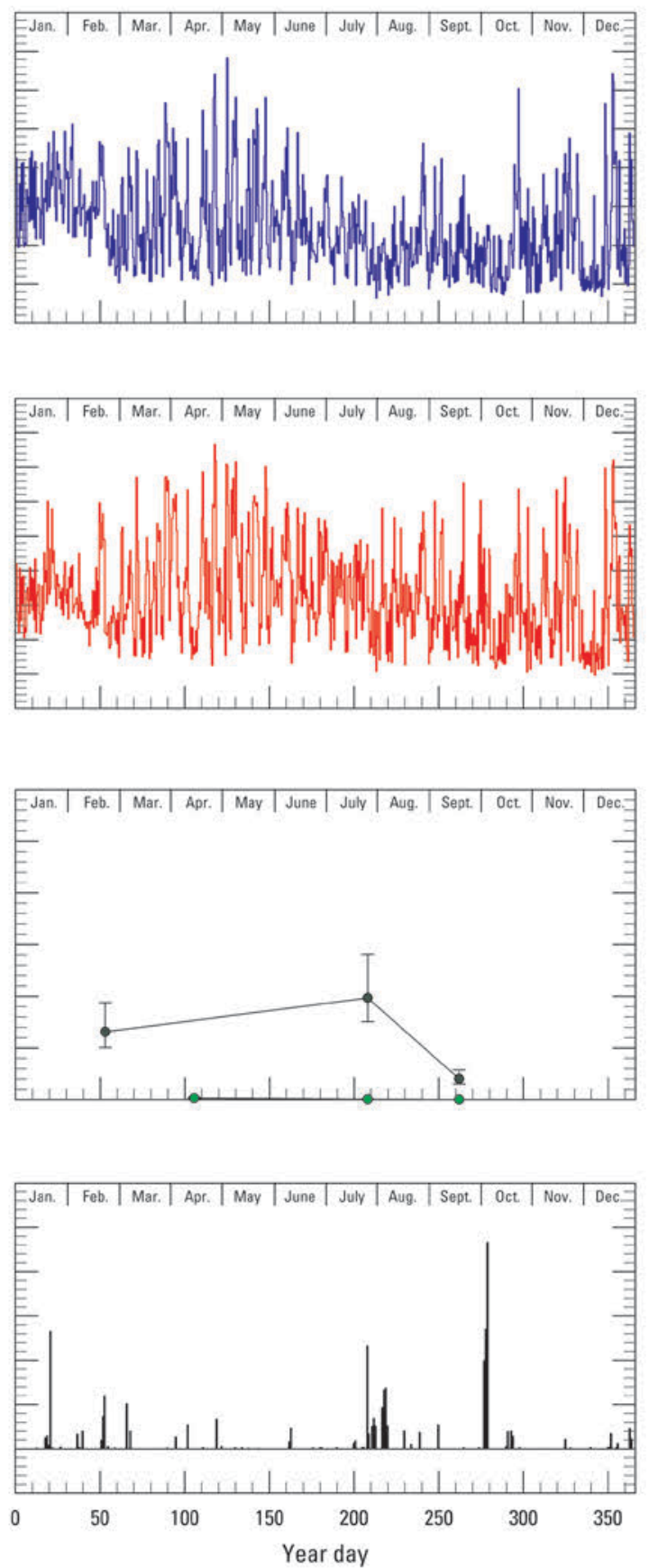

Figure 31. Plots showing wind, aeolian sand-transport, and rainfall data collected at the instrument station AZ C:13:0336 U in Grand Canyon, Arizona, 2009-10. Wind speed is presented as diurnal average values, using daytime (0600-1800 hours) and nighttime (1800-0600 hours) averages of data collected at 4-minute intervals. Gust speed is shown as maximum values that occurred during each diurnal interval. Daily sand transport is plotted in grams, normalized to a width of 1 centimeter. To obtain these values, total sand mass collected from four traps during each maintenance visit was divided by the number of days since the trap had last been emptied. The lower of the two sand-transport lines plotted indicates transport rates measured at the lower set of traps at this station (AZ C:13:0336 L). Rainfall is plotted as daily (24-hour) totals. 
Site AZ C:13:0321

One set of BSNE sand traps measures sand-transport rates in an aeolian sand deposit near river level at AZ C:13:0321 with 30 percent vegetation cover (Draut, 2011). At this site, large (>10 m high), well-established aeolian dunes are present inland from a fluvial sandbar and above the post-dam high water level. Although wind conditions are not measured directly at this site, the orientation of dune slip faces indicates migration toward the northeast (inland), indicating that this site most likely is an MFS aeolian deposit downwind of an active, modern sandbar (Draut and others, 2010).

Daily sand flux measured near site AZ C:13:0321 was substantially higher during 2010 (2-6 $\mathrm{g} / \mathrm{cm}$ ) than during $2009(1-3 \mathrm{~g} / \mathrm{cm})$ (fig. 33). The southwest-toward-northeast dune migration is consistent with net sediment-transport directions derived from wind measurements at the nearest weather stations (at site AZ C:13:0346), which are $700 \mathrm{~m}$ away from site AZ C:13:0321 (fig. 34).
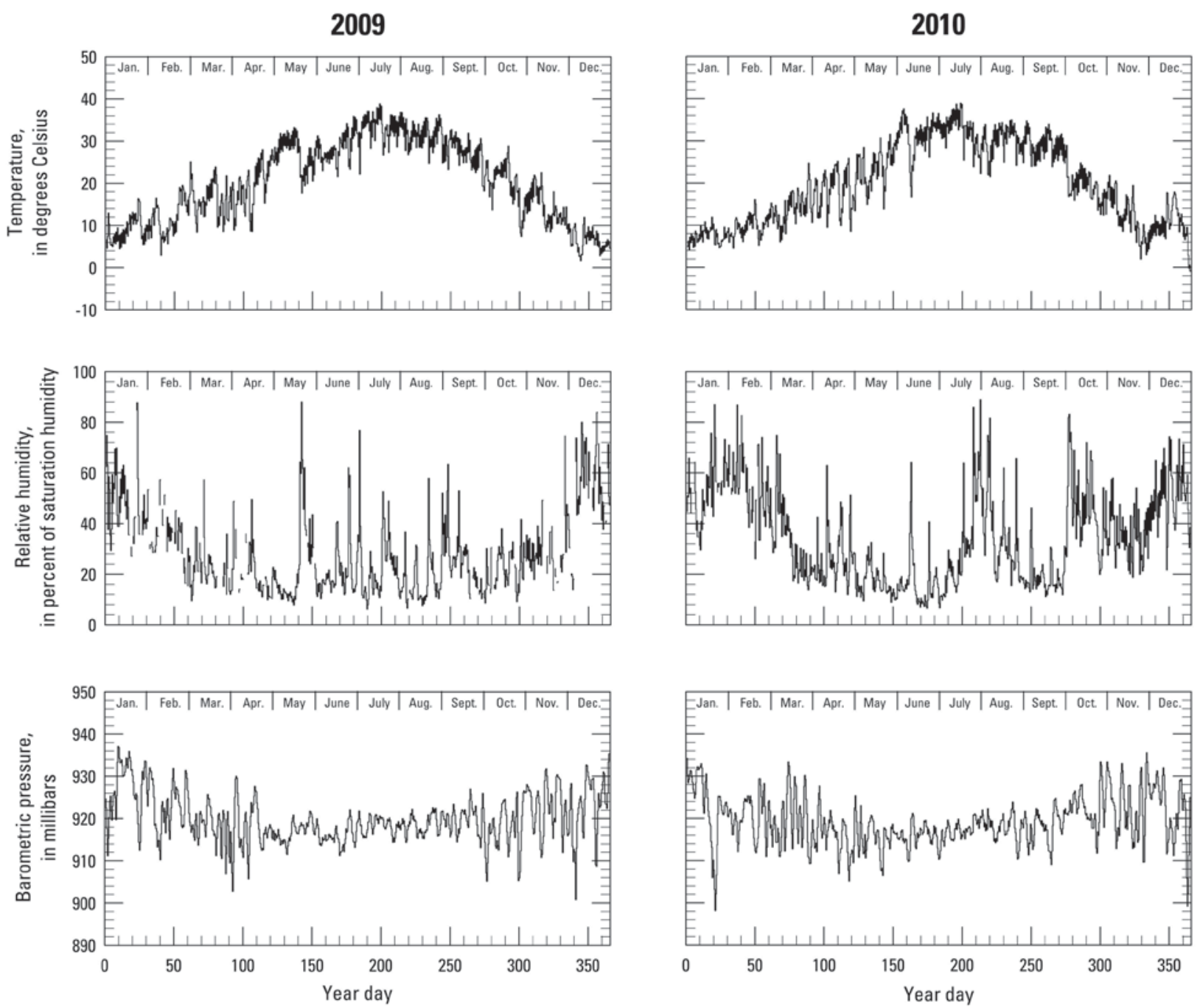

Figure 32. Plots showing temperature, relative humidity, and barometric pressure data collected at instrument station AZ C:13:0336 U in Grand Canyon, Arizona, 2009-10. All parameters are plotted as diurnal averages (defined using 0600-1800 and 1800-0600 hours). 

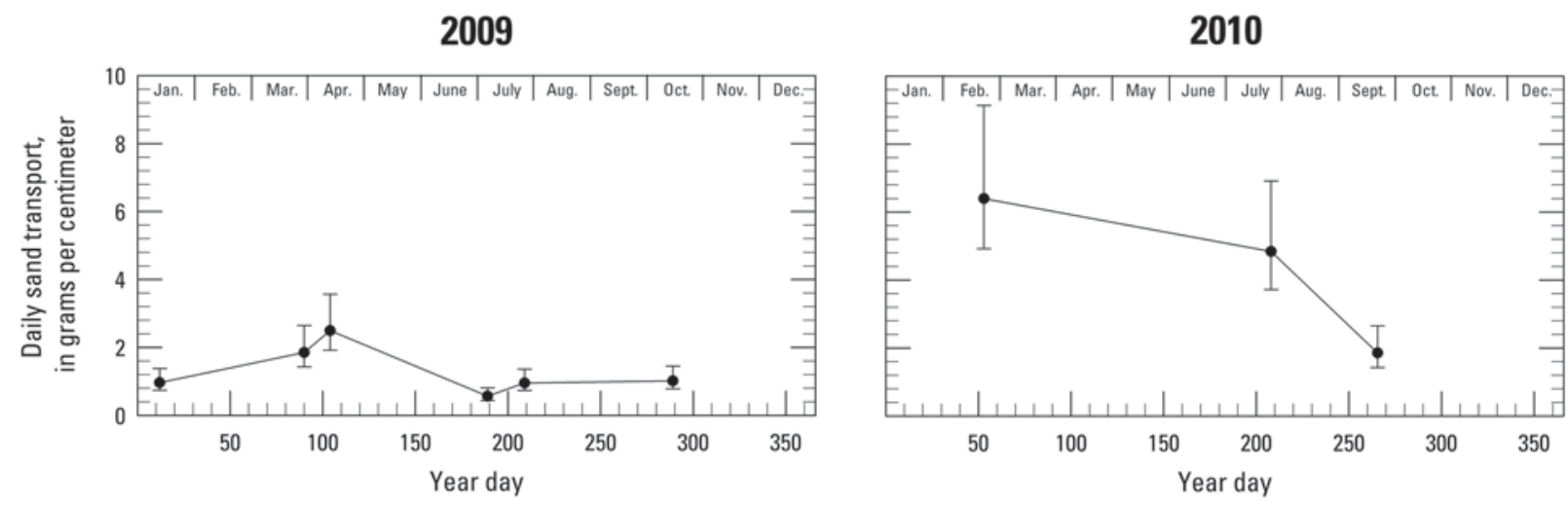

Figure 33. Plots showing aeolian sand-transport data collected near AZ C:13:0321 in Grand Canyon, Arizona, 2010. Daily sand transport is plotted in grams, normalized to a width of 1 centimeters. To obtain these values, total sand mass collected from four traps during each maintenance visit was divided by the number of days since the trap had last been emptied. 


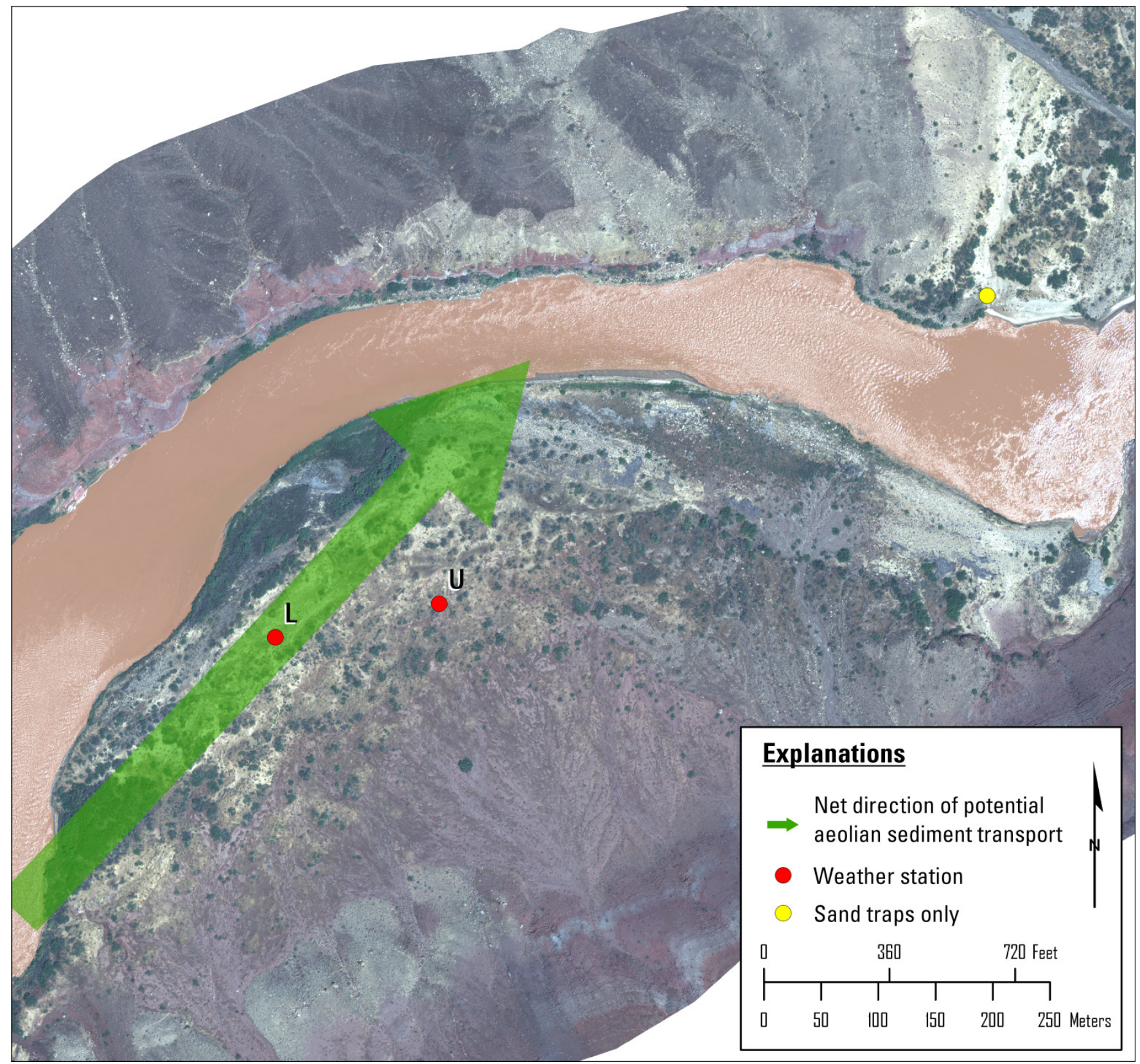

Figure 34. Aerial photograph of the area around site AZ C:13:0346 in Grand Canyon, Arizona. Arrow indicates the net direction of potential aeolian sediment transport measured at AZ C:13:0346 $L$ in 2010. A vector sum of the Qp proxy variable (equation 1), calculated using all the wind data collected during dry conditions from station $A Z$ C:13:0346 L in 2010, indicates net sediment transport from $217^{\circ}$. Yellow dot in upper right corner designates sand traps at AZ C:13:321. 
Site AZ C:13:0346

Two instrument stations operated in 2010 near river mile 70, AZ C:13:0346 L and AZ C:13:0346 U. This reach of the Colorado River corridor in eastern Grand Canyon is several kilometers wide, is characterized by broad meander bends in the river, and is a continuation of the geomorphic setting referred to as the Furnace Flats reach by Schmidt and Graf (1990). The dune field at this site generally is bordered by riparian vegetation and not by sandbars (fig. 34). Draut $(2011,2012)$ interpreted the aeolian dune field in this area as relict fluvial sourced, receiving negligible new sediment influx from modern sand bars. Station AZ C:13:0346 L is in the dune field that has well-developed dune forms and locally active sediment transport.

The Nexsens ${ }^{\text {TM }}$ data logger at station AZ C:13:0346 L reached its maximum storage capacity on September 16, 2010, and randomly overwrote stored data to continue storing new data. The data download in September 2010 was terminated before the downloading of all data could be completed because of trip logistics. Although the data logger was programmed to stop collecting data once it reached its storage capacity, the data logger malfunctioned and overwrote previously collected data, resulting in some data loss from this station.

Wind speed and direction measured at station AZ C:13:0346 L in 2010 are plotted in figure 35. Cumulative rainfall data are shown in figure 36; approximate total rainfall measured at that station in 2010, excluding 14 days of data between September 16 and December 31, was $233.0 \mathrm{~mm}$ (table 2). All weather parameters and sand transport measured at station AZ C:13:0346 L in 2010 are summarized in figures 37 and 38, with 2009 data shown for comparison.

A vector sum of available wind data from weather station AZ C:13:0346 L in 2010 (excluding the dates of malfunction) yields a net $Q p$ magnitude of $652,360 \mathrm{~m}^{3} / \mathrm{s}^{3}$ from a direction of $217^{\circ}$; using wind data collected from the same time interval only when the sand is estimated to have been dry, a vector sum yields a net $Q p$ magnitude of $362,210 \mathrm{~m}^{3} / \mathrm{s}^{3}$ from a direction of $223^{\circ}$ (table 3). These net potential sand-transport directions reflect a strong directional component from the west-southwest (fig. 34). Daily sand-transport rates in 2010 at station AZ C:13:0346 L were highest in spring (April-May), and were lower in magnitude compared to those in spring (March-April) 2009 (fig. 37). 


\section{Station AZ C:13:0346 L}

4-minute average wind speed, in meters per second and wind direction, in degrees True

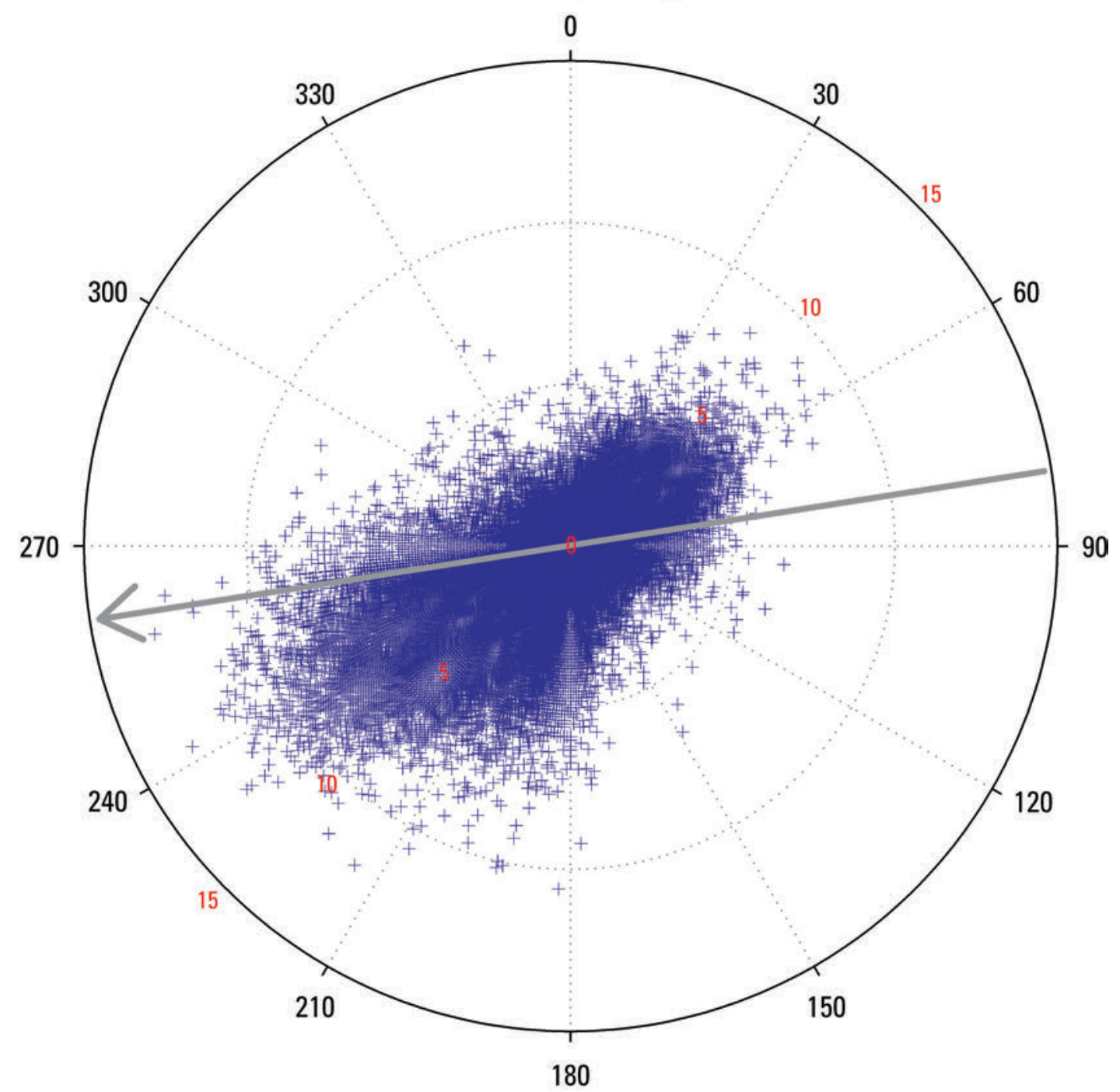

Figure 35. Plot showing magnitude and direction of wind velocity measured at the instrument station $A Z$ C:13:0346 L with 4-minute resolution in Grand Canyon, Arizona, 2010. Magnitude is indicated by the concentric circles, and compass bearing indicates the wind. The gray arrow shows the orientation of the river corridor $\left(261^{\circ}\right)$; river flow is toward the west. 


\section{Station AZ C:13:0346 L}

Cumulative rainfall

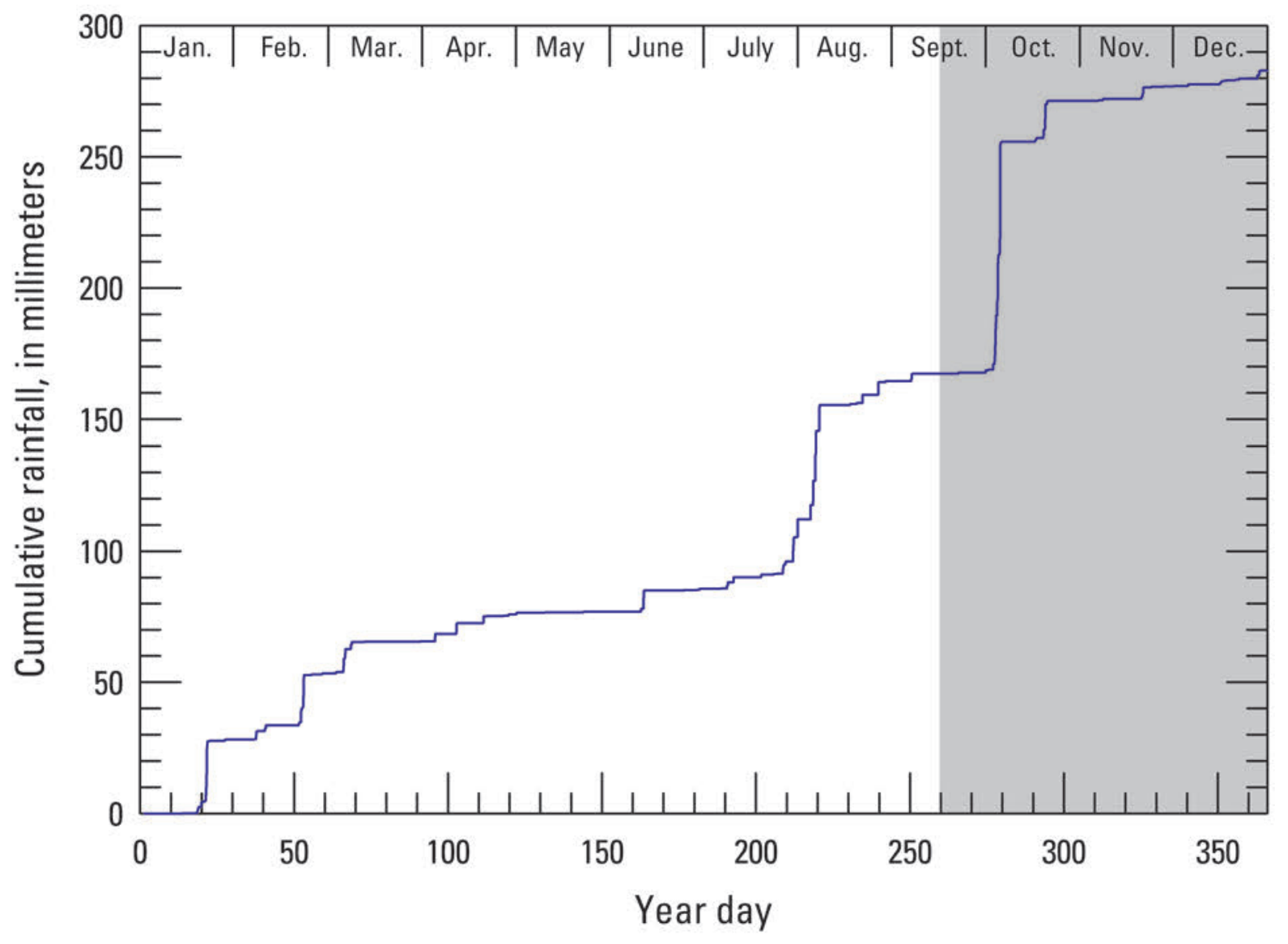

Figure 36. Plot showing cumulative rainfall recorded at station AZ C:13:0346 L compiled from data collected at 4-minute resolution in Grand Canyon, Arizona, 2010. Gray shading indicates that isolated occurrences of station malfunction occurred on 14 days between September 16 and December 31, 2010, during which period no data were collected. The cumulative rainfall data, therefore, represents minimum values for this station after September 16, 2010. 

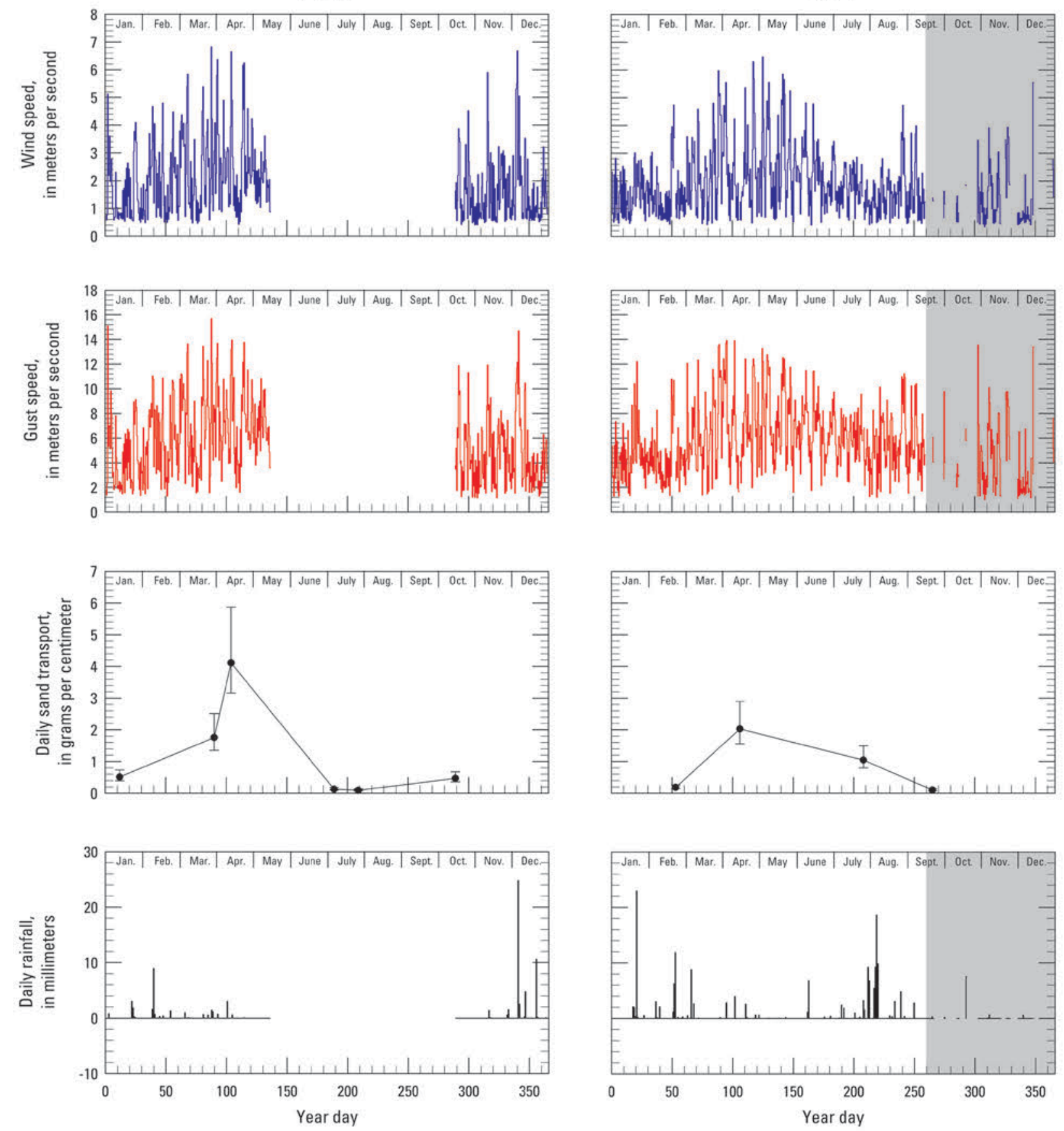

Figure 37. Plots showing wind, aeolian sand-transport, and rainfall data collected at the instrument station AZ C:13:0346 L, in Grand Canyon, Arizona, 2009-10. Wind speed is presented as diurnal average values, using daytime (0600-1800 hours) and nighttime (1800-0600 hours) averages of data collected at 4-minute intervals. Gust speed is shown as maximum values that occurred during each diurnal interval. Daily sand transport is plotted in grams, normalized to a width of 1 centimeter. To obtain these values, total sand mass collected from four traps during each maintenance visit was divided by the number of days since the trap had last been emptied. Rainfall is plotted as daily (24-hour) totals. Gray shading indicates that isolated occurrences of station malfunction occurred on 14 days between September 16 and December 31, 2010, during which period no data were collected. 

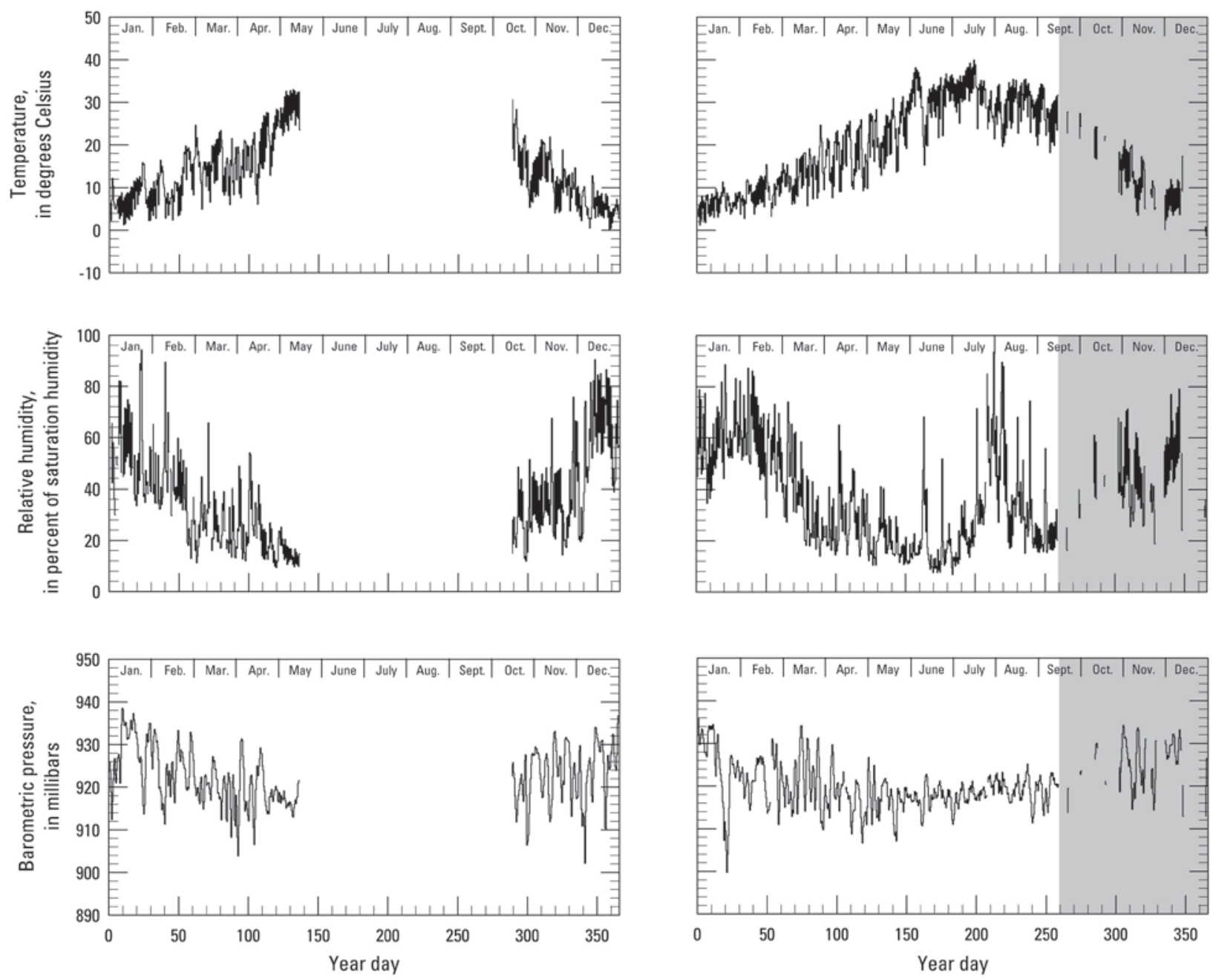

Figure 38. Plots showing temperature, relative humidity, and barometric pressure data collected at instrument station AZ C:13:0346 L in Grand Canyon, Arizona, 2009-10. All parameters are plotted as diurnal averages (defined using 0600-1800 and 1800-0600 hours). Gray shading indicates that isolated occurrences of station malfunction occurred on 14 days between September 16 and December 31, 2010, during which period no data were collected. 
Station AZ C:13:0346 U is upstream of station AZ C:13:0346 L and slightly farther inland from the river (fig. 39). The land surface near station AZ C:13:0346 U includes relatively inactive dunes on a broad, flat landscape with abundant silty material, some derived from relict fluvial deposits and some composed of distal slopewash from local bedrock. Biological soil crust is more abundant around station AZ C:13:0346 U than around station AZ C:13:0346 L (Draut, 2011). Wind speed and direction measured at station AZ C:13:0346 U in 2010 are plotted in figure 40. Cumulative rainfall data are shown in figure 41; total rainfall measured in 2010 was $308.1 \mathrm{~mm}$ (table 2). All weather parameters and sand transport measured at station AZ C:13:0346 U in 2010 are summarized in figures 42 and 43, with 2009 data shown for comparison.

A vector sum of all available wind data from station AZ C:13:0346 U in 2010 yields a net Qp magnitude of $500,130 \mathrm{~m}^{3} / \mathrm{s}^{3}$ from a direction of $225^{\circ}$; using wind data collected only when the sand is estimated to have been dry, a vector sum yields a net $Q p$ magnitude of 330,000 $\mathrm{m}^{3} / \mathrm{s}^{3}$ from a direction of $228^{\circ}$ (table 3). These net potential sand-transport directions reflect a consistent directional component from the southwest (fig. 39).

The highest wind speeds in 2010 were observed slightly later (April-May) than in 2009 (MarchApril) (fig. 42). Sand-transport rates at station AZ C:13:0346 U generally decreased between 2007 and 2010, likely attributable to increasing vegetation cover over that time period. The greater amount of precipitation recorded in 2010 compared to 2009 may have been another contributing factor. 


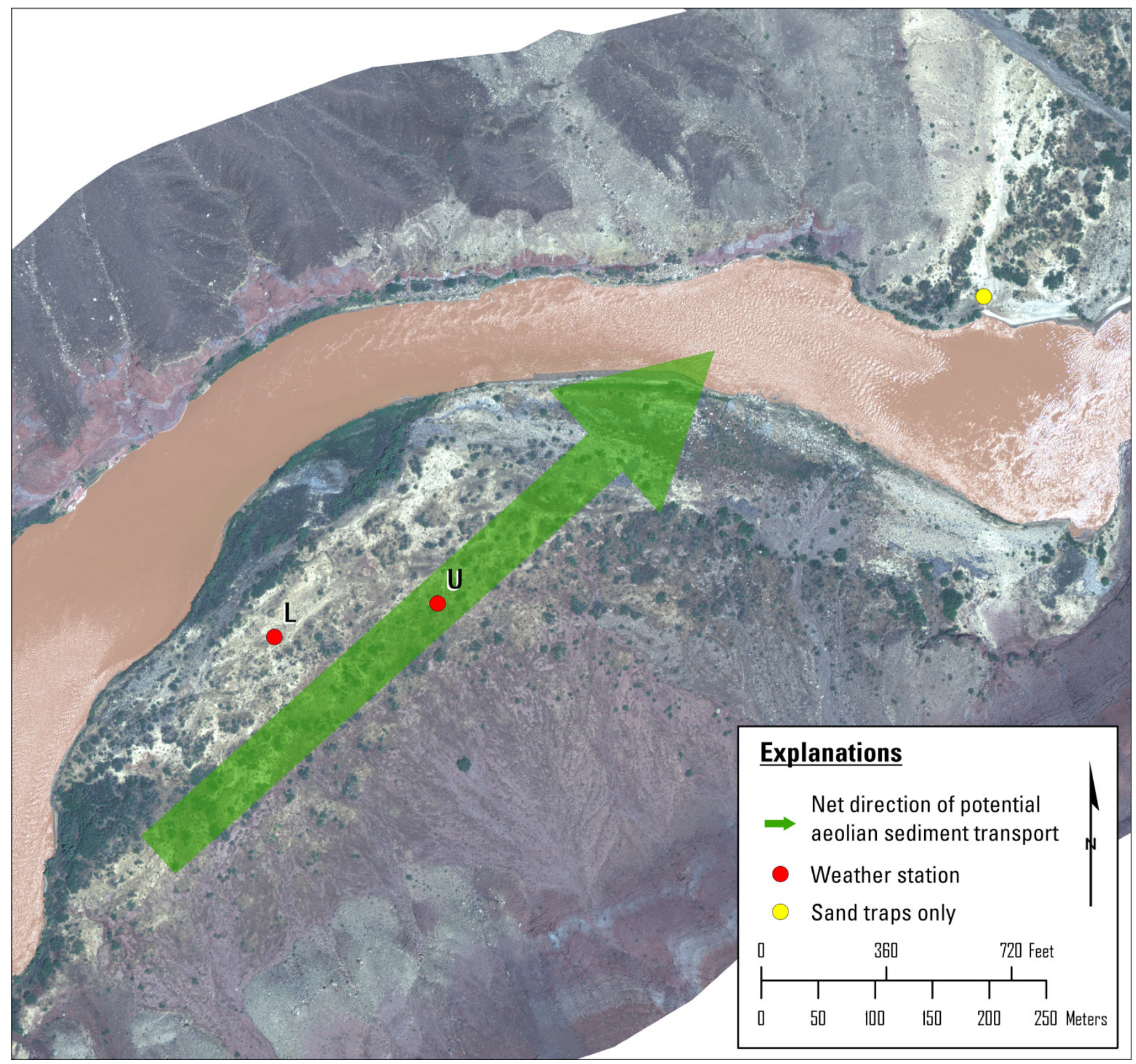

Figure 39. Aerial photograph of the area around site AZ C:13:0346 in Grand Canyon, Arizona. Arrow indicates the net direction of potential aeolian sediment transport measured at AZ C:13:0346 U in 2010. A vector sum of the $Q p$ proxy variable (equation 1 ), calculated using all the wind data collected during dry conditions from AZ C:13:0346 U in 2010, indicates net sediment transport from $225^{\circ}$. 


\section{Station AZ C:13:0346 U}

\section{4-minute average wind speed, in meters per second}

and wind direction, in degrees True

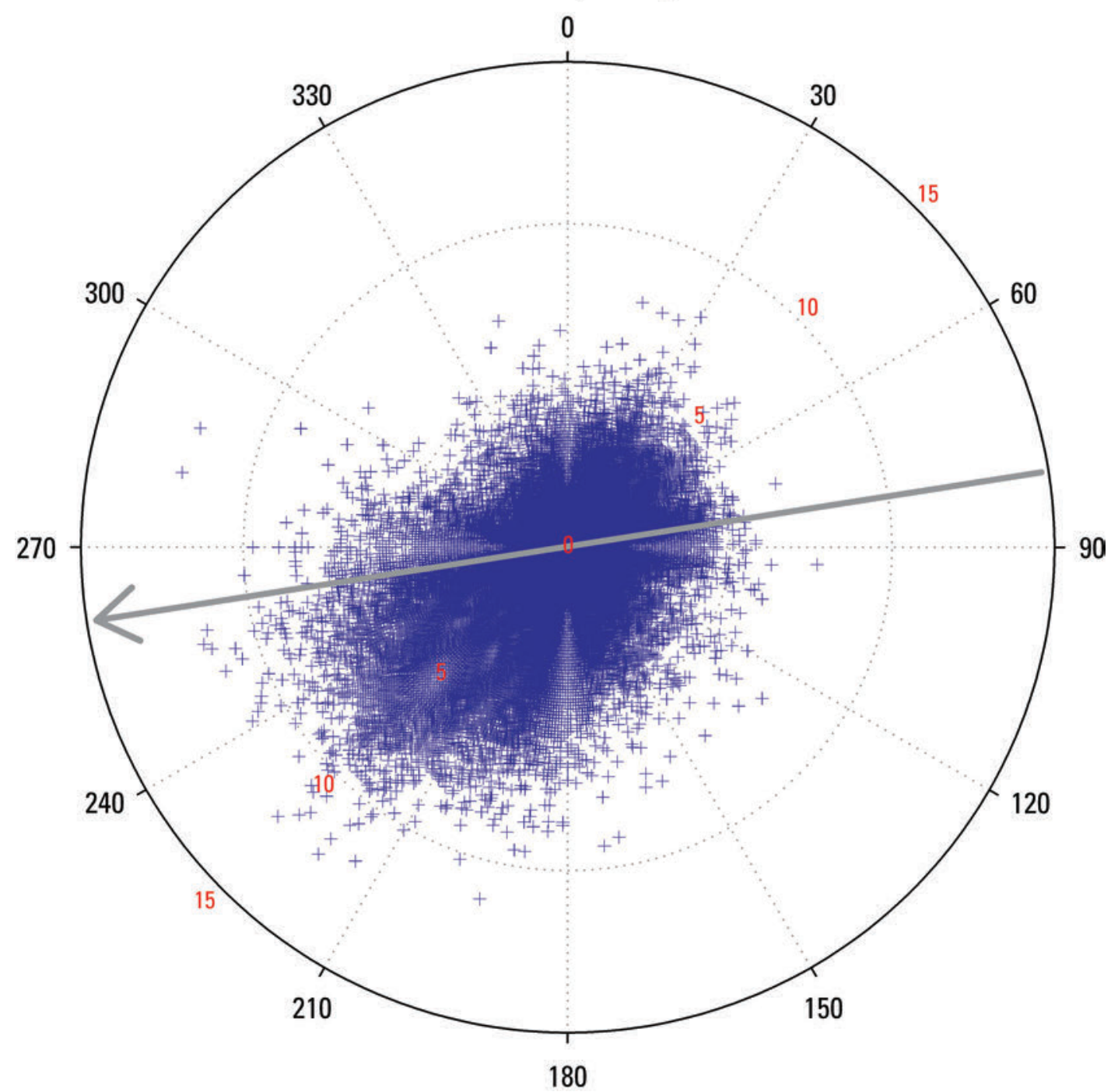

Figure 40. Plot showing magnitude and direction of wind velocity measured at the instrument station AZ C:13:0346 U with 4-minute resolution in Grand Canyon, Arizona, 2010. Magnitude is indicated by the concentric circles, and compass bearing indicates the wind direction. The gray arrow shows the orientation of the river corridor $\left(261^{\circ}\right)$; river flow is toward the west. 


\section{Station AZ C:13:0346 U}

Cumulative rainfall

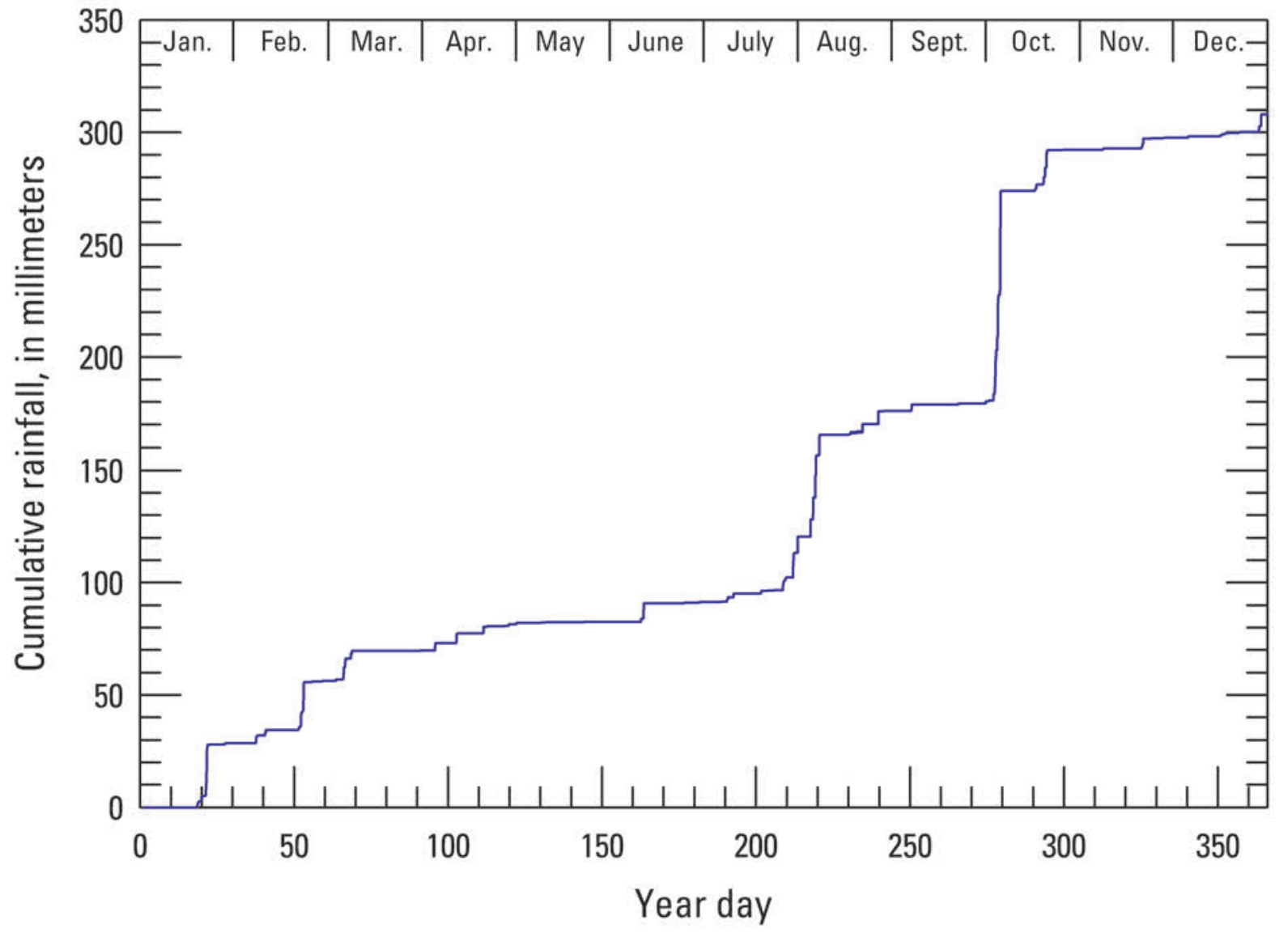

Figure 41. Plot showing cumulative rainfall recorded at station AZ C:13:0346 U compiled from data collected at 4-minute resolution in Grand Canyon, Arizona, 2010. 
2009
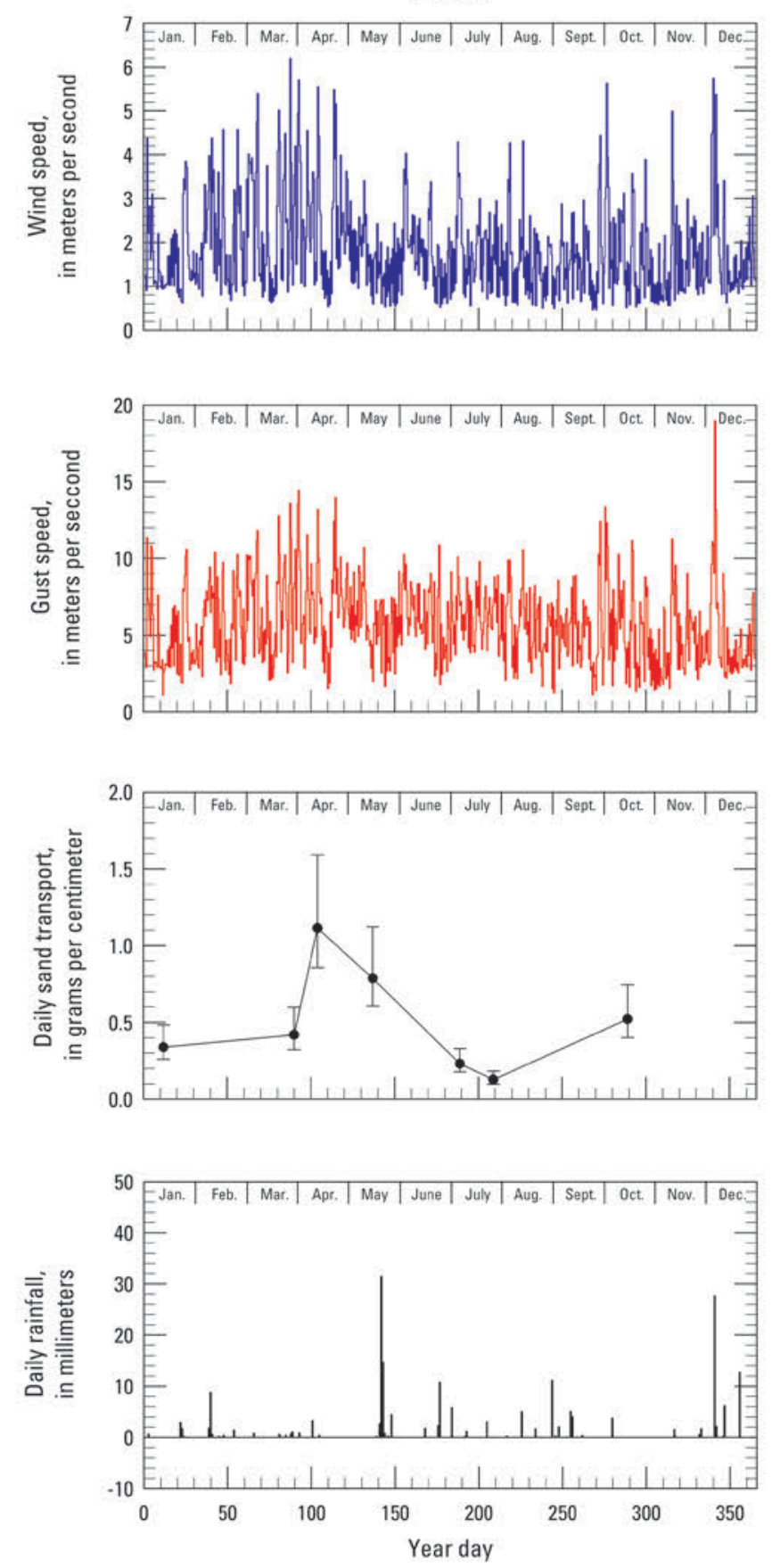

2010
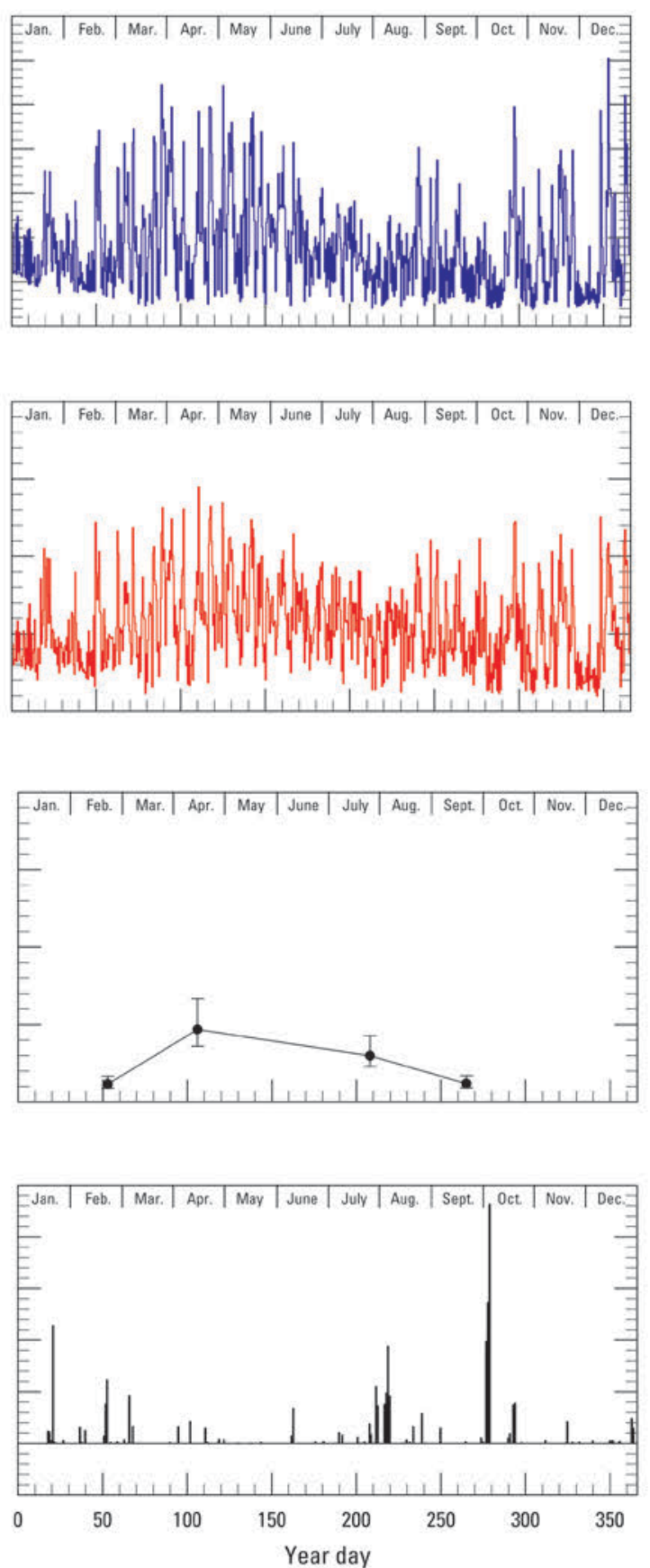

Figure 42. Plots showing wind, aeolian sand-transport, and rainfall data collected at the instrument station AZ C:13:0346 U in Grand Canyon, Arizona, 2009-10. Wind speed is presented as diurnal average values, using daytime (0600-1800 hours) and nighttime (1800-0600 hours) averages of data collected at 4-minute intervals. Gust speed is shown as maximum values that occurred during each diurnal interval. Daily sand transport is plotted in grams, normalized to a width of 1 centimeter. To obtain these values, total sand mass collected from four traps during each maintenance visit was divided by the number of days since the trap had last been emptied. Rainfall is plotted as daily (24-hour) totals. 

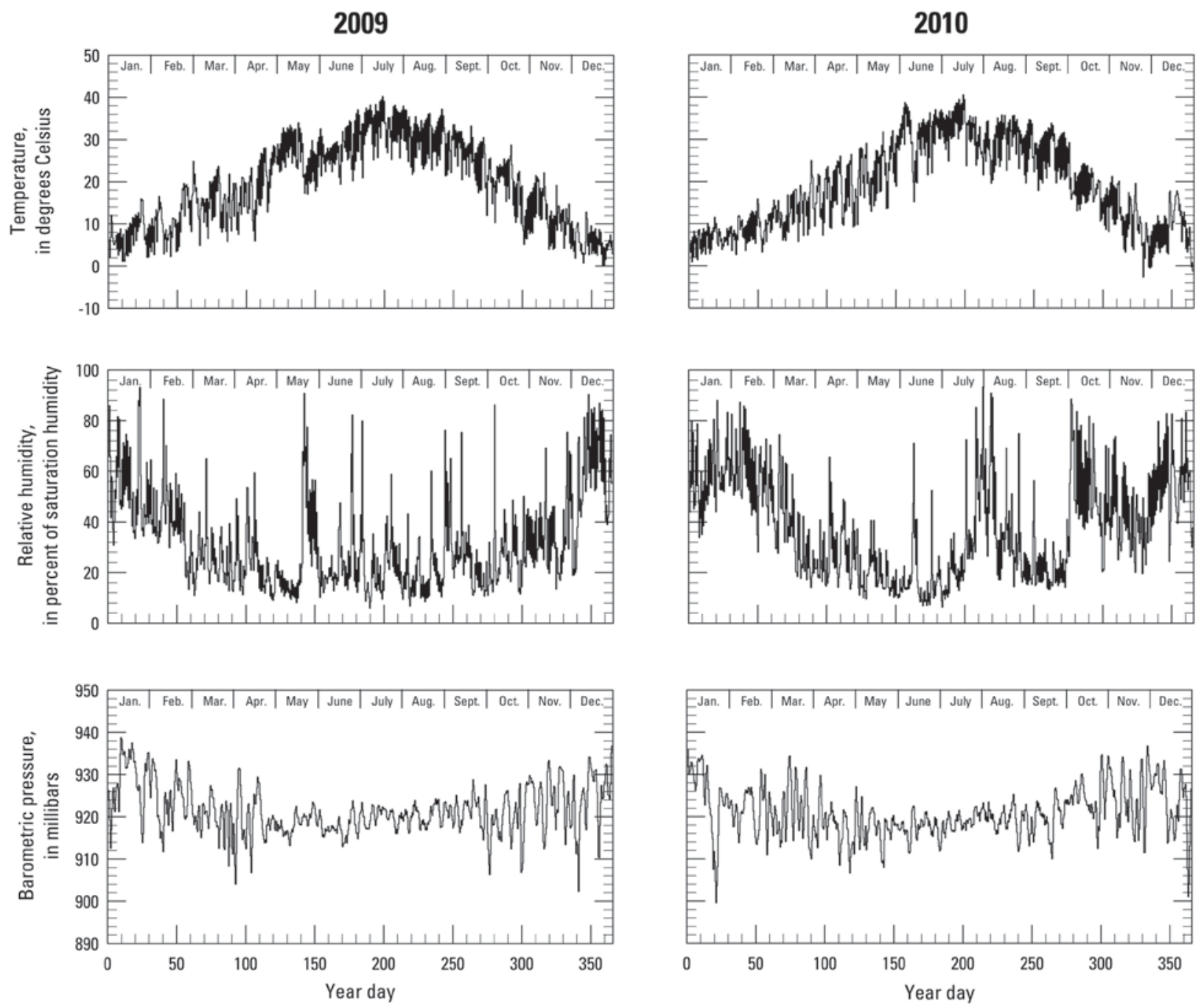

Figure 43. Plots showing temperature, relative humidity, and barometric pressure data collected at instrument station AZ C:13:0346 U in Grand Canyon, Arizona, 2009-10. All parameters are plotted as diurnal averages (defined using 0600-1800 and 1800-0600 hours). 
Site AZ B:11:0281

One instrument station operated near site AZ B:11:0281 throughout 2010 with no interruptions. This station is on the upstream side of a small debris fan that formed at the mouth of an ephemeral tributary drainage (fig. 44). The land surface at this site is composed of moderately active aeolian dunes with moderate vegetation cover and biological soil crust. Inland from the river on its south side, finegrained sedimentary deposits occur near site AZ B:11:0281 that are thought to have been deposited as the river flow ponded behind a large landslide deposit (Huntoon, 2003), temporarily damming the river $3 \mathrm{~km}$ downstream about 20 thousand years ago (R.H. Webb, USGS scientist, written comm., 2008).

Wind speed and direction measured at site AZ B:11:0281 in 2010 are plotted in figure 45. Cumulative rainfall data are shown in figure 46; total rainfall measured in 2010 was 421.8 mm (table 2). All weather parameters and sand transport measured at site AZ B:11:0281 in 2010 are summarized in figures 47 and 48, with 2009 data shown for comparison.

A vector sum of all wind data from site AZ B:11:0281 in 2010 yields a net $Q p$ magnitude of $257,450 \mathrm{~m}^{3} / \mathrm{s}^{3}$ from a direction of $104^{\circ}$; using wind data collected only when the sand is estimated to have been dry, a vector sum yields a net $Q p$ magnitude of 208,770 $\mathrm{m}^{3} / \mathrm{s}^{3}$ from a direction of $105^{\circ}$ (table 3). These net potential sand-transport directions reflect a consistent directional component from the eastsoutheast (fig. 44). Spring sand transport around site AZ B:11:0281 showed only a marginal increase during the spring windy season from 2008 to 2009, and again from 2009 to 2010, but showed a substantial increase in the summer. Daily sand-transport rates were greater than $0.1 \mathrm{~g} / \mathrm{cm}$ between April and July of 2010, whereas they remained less than $0.1 \mathrm{~g} / \mathrm{cm}$ for most of 2009. The relatively low sandtransport rates at this site may be attributed to vegetation upwind (east) of the sand traps that limited sand entrainment. 


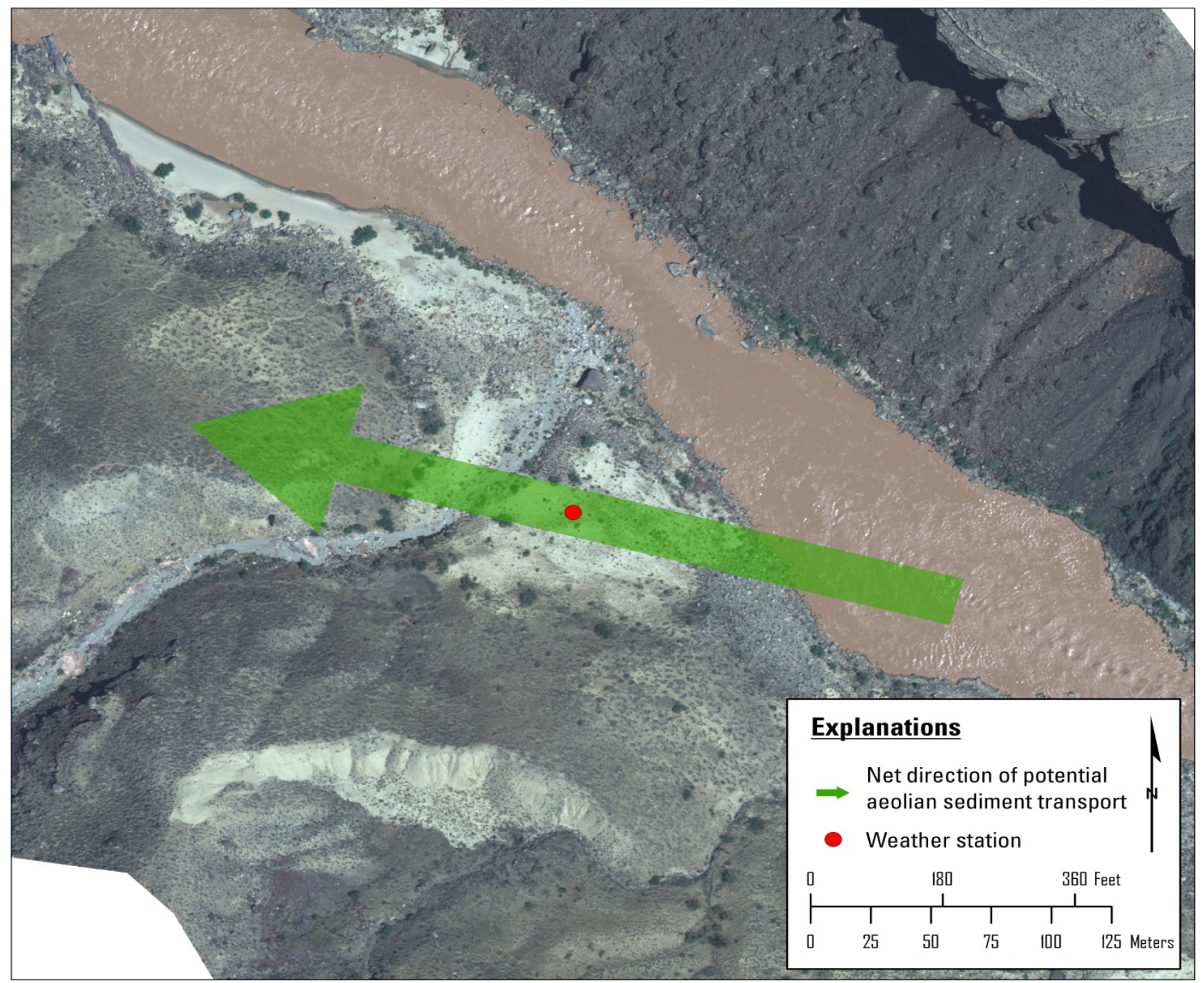

Figure 44. Aerial photograph of the area around site AZ B:11:0281 in Grand Canyon, Arizona. Arrow indicates the net direction of potential aeolian sediment transport measured at AZ B:11:0281 in 2010. A vector sum of the $Q p$ proxy variable (equation 1), calculated using all the wind data collected during dry conditions from AZ B:11:0281 in 2010, indicates net sediment transport from $104^{\circ}$. 


\section{Station AZ B:11:0281}

4-minute average wind speed, in meters per second and wind direction, in degrees True

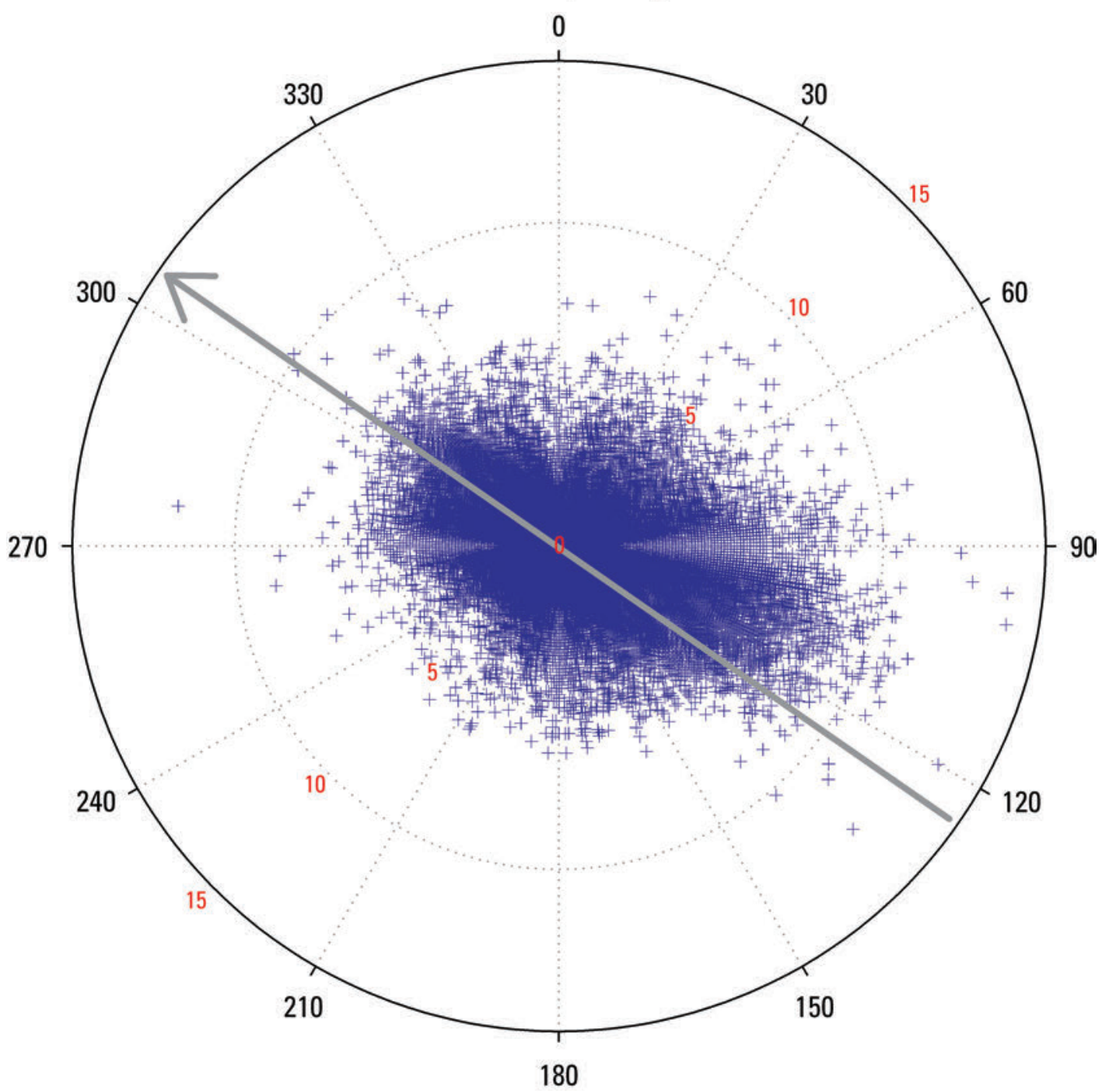

Figure 45. Plot showing magnitude and direction of wind velocity measured at the instrument station $A Z$ B:11:0281 with 4-minute resolution in Grand Canyon, Arizona, 2010. Magnitude is indicated by the concentric circles, and compass bearing indicates the wind direction. The gray arrow shows the orientation of the river corridor $\left(305^{\circ}\right)$; river flow is toward the northwest. 


\section{Station AZ B:11:0281}

Cumulative rainfall

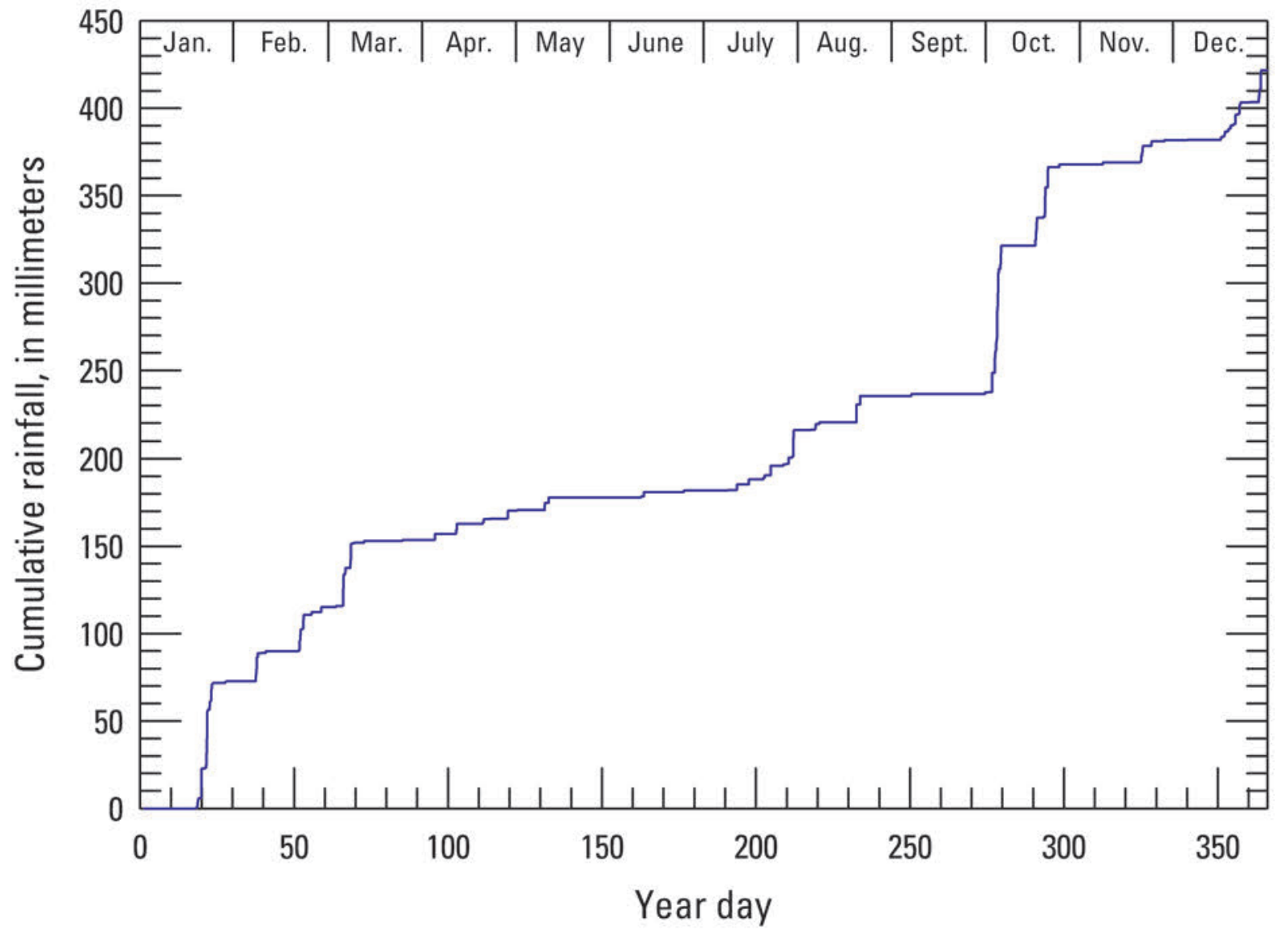

Figure 46. Plot showing cumulative rainfall recorded at site AZ B:11:0281 compiled from data collected at 4minute resolution in Grand Canyon, Arizona, 2010. 

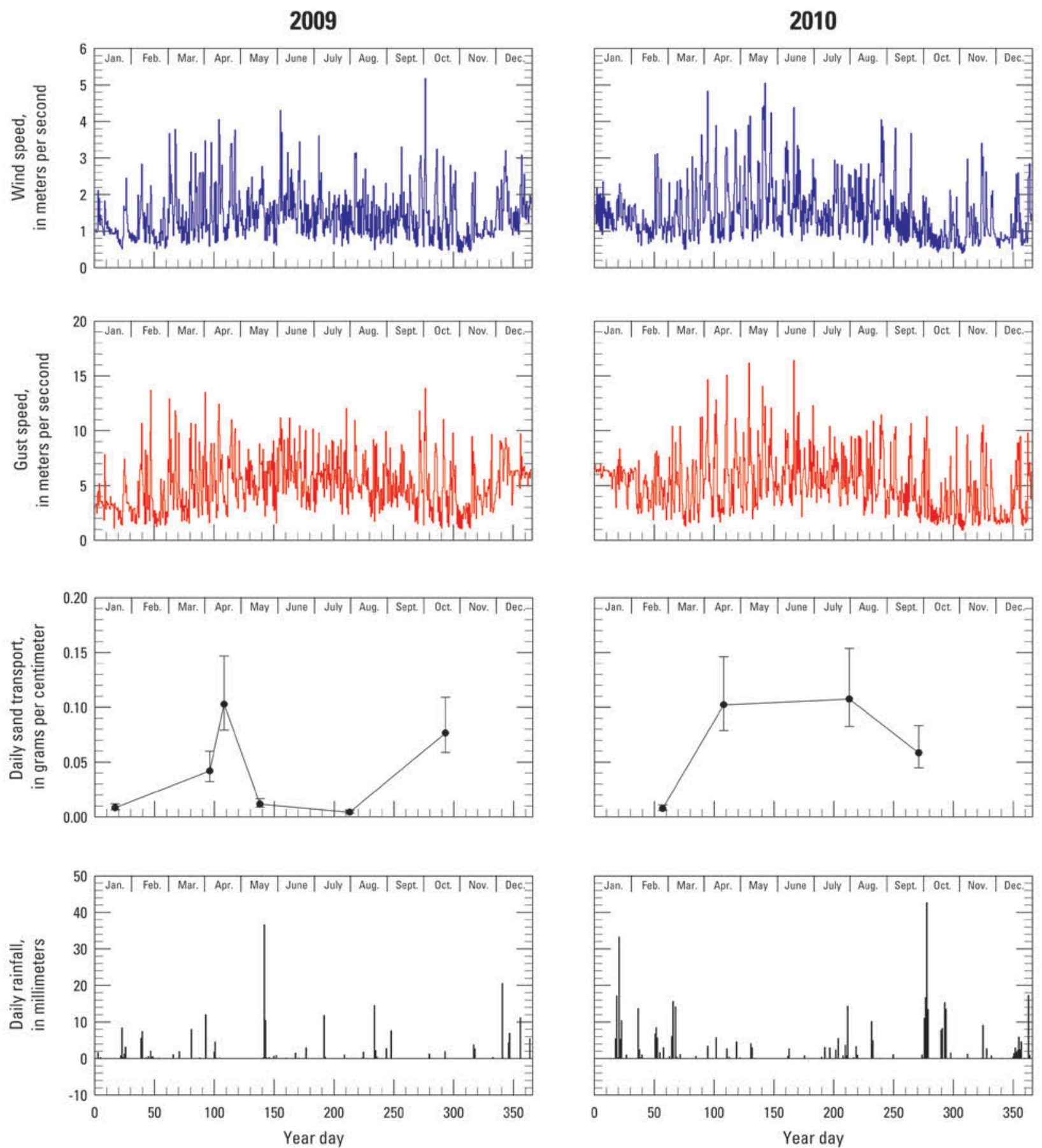

Figure 47. Plots showing wind, aeolian sand-transport, and rainfall data collected at the instrument station AZ B:11:0281, in Grand Canyon, Arizona, 2009-10. Wind speed is presented as diurnal average values, using daytime (0600-1800 hours) and nighttime (1800-0600 hours) averages of data collected at 4-minute intervals. Gust speed is shown as maximum values that occurred during each diurnal interval. Daily sand transport is plotted in grams, normalized to a width of 1 centimeter. To obtain these values, total sand mass collected from four traps during each maintenance visit was divided by the number of days since the trap had last been emptied. Rainfall is plotted as daily (24-hour) totals. 

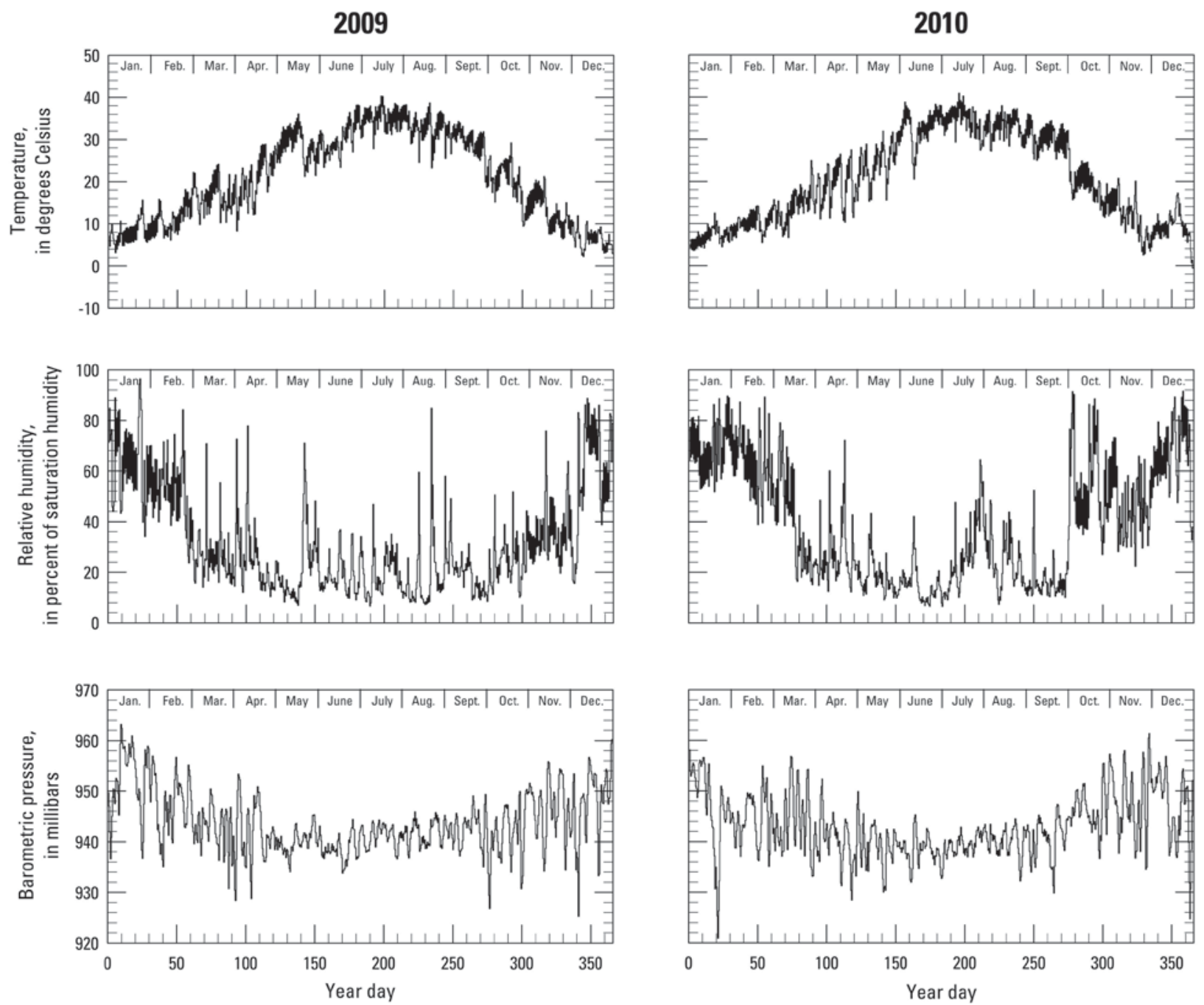

Figure 48. Plots showing temperature, relative humidity, and barometric pressure data collected at instrument station AZ B:11:0281 in Grand Canyon, Arizona, 2009-10. All parameters are plotted as diurnal averages (defined using 0600-1800 and 1800-0600 hours). 
Site AZ A:15:0033

One instrument station operated near archeological site AZ A:15:0033 in 2010. No data were collected by the instrument station between September 2 and 29, 2010, because of a loss of power as a result of rodent damage to the power cable. The power cable was replaced and the station operated without interruption for the remainder of the year. The study site includes an aeolian dune field near river level that is covered by relatively dense vegetation (63 percent area cover according to Draut, 2011) (fig. 49). The vegetation has overgrown the dune field and a large river-level sandbar just downstream of the dune field since the 1960s, and now covers much of the previously open sand (Draut and Rubin, 2008).

Wind speed and direction measured at site AZ A:15:0033 in 2010 are plotted in figure 50. Cumulative rainfall data are shown in figure 51; total rainfall measured while the station was operating in 2010 was $357.4 \mathrm{~mm}$, excluding the data gap in September, mentioned above (table 2). All weather parameters and sand transport measured at site A:15:0033 in 2010 are summarized in figures 52 and 53, with 2009 data shown for comparison.

Wind conditions measured at station AZ A:15:0033 in past years (2004 through 2009) have been complex; although upstream and downstream winds nearly balanced each other, vector components from the north-northeast can result in net potential sand flux toward the river at times (Draut and Rubin, 2006, 2008). A vector sum of all wind data from site AZ A:15:0033 in 2010 yields a net $Q p$ magnitude of $16,664 \mathrm{~m}^{3} / \mathrm{s}^{3}$ from a direction of $185^{\circ}$; using wind data only from when the sand is estimated to have been dry, a vector sum yields a net $Q p$ magnitude of $11,782 \mathrm{~m}^{3} / \mathrm{s}^{3}$ from a direction of $194^{\circ}$ (table 3). These magnitudes of net potential sand-transport are comparable to those of 2009 at the same location. Although the net transport was from a more southwesterly direction in 2010 compared to 2009 (221 ${ }^{\circ}$ for all wind data and $225^{\circ}$ for dry conditions), as in past years, the net potential sand-transport directions reflect a balance between upstream and downstream winds, with only a slightly dominant net transport vector from the southwest (figs. 49 and 50).

As in past years, daily sand-transport rates at site AZ A:15:0033 were the lowest measured at any study site in 2010 - always less than $0.02 \mathrm{~g} / \mathrm{cm}$, even during spring winds when gust speeds exceeded 10 $\mathrm{m} / \mathrm{s}$ (fig. 52). This is attributed to the density of vegetation cover near the instrument station, which effectively inhibits entrainment of sand by decreasing wind velocity near the bed (Bressolier and Thomas, 1977; Buckley, 1987). Sand transport at this site was no higher in the spring than at other times of year in 2007, 2008, 2009, or 2010 (fig. 52; Draut and others, 2009a). 


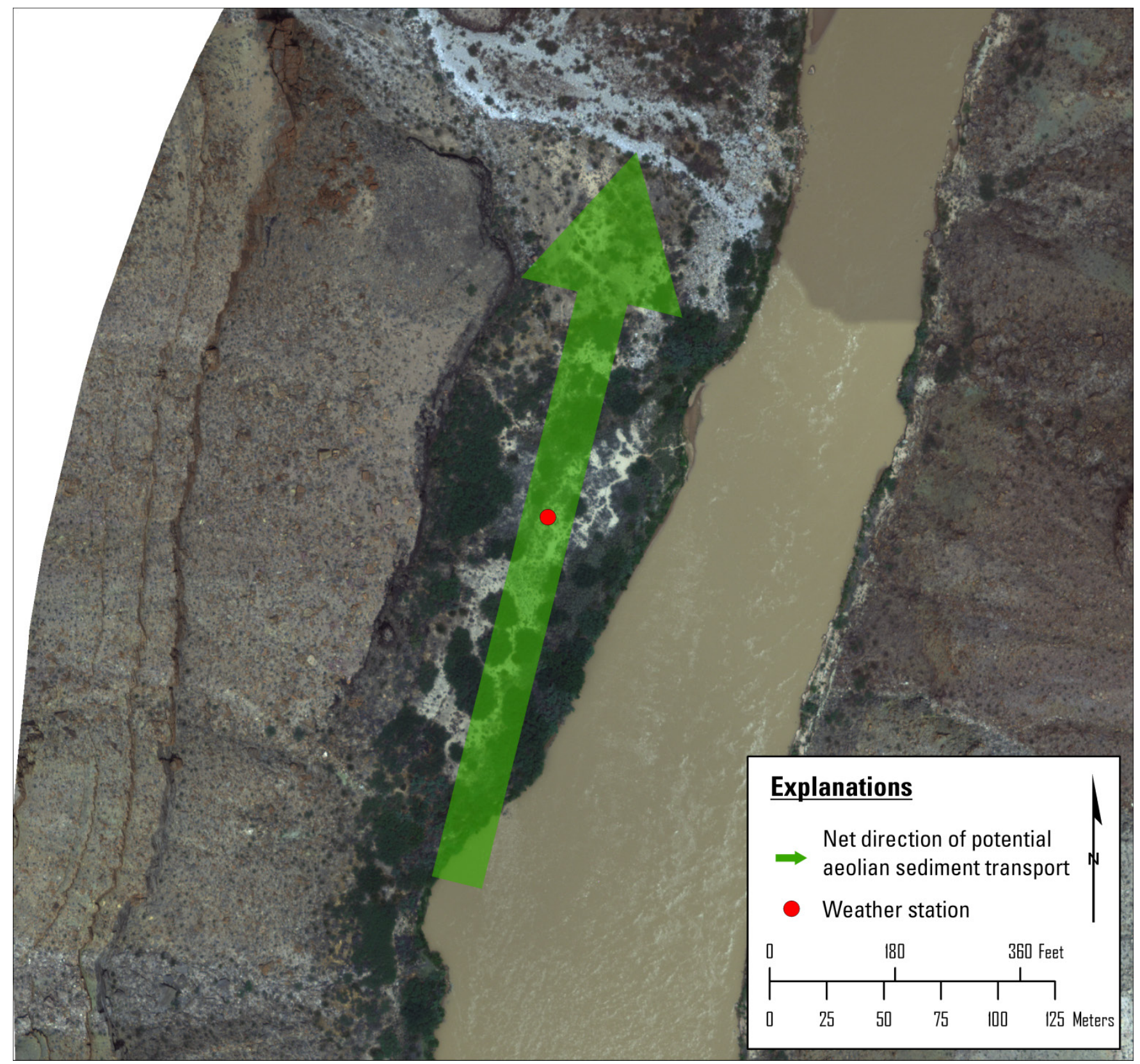

Figure 49. Aerial photograph of the area around site AZ A:15:0033 in Grand Canyon, Arizona. Arrow indicates the net direction of potential aeolian sediment transport measured at AZ A:15:0033 in 2010. A vector sum of the $Q p$ proxy variable (equation 1), calculated using all the wind data collected during dry conditions from AZ A:15:0033 in 2010, indicates net sediment transport from $185^{\circ}$. 


\section{Station AZ A:15:0033}

\section{4-minute average wind speed, in meters per second}

and wind direction, in degrees True

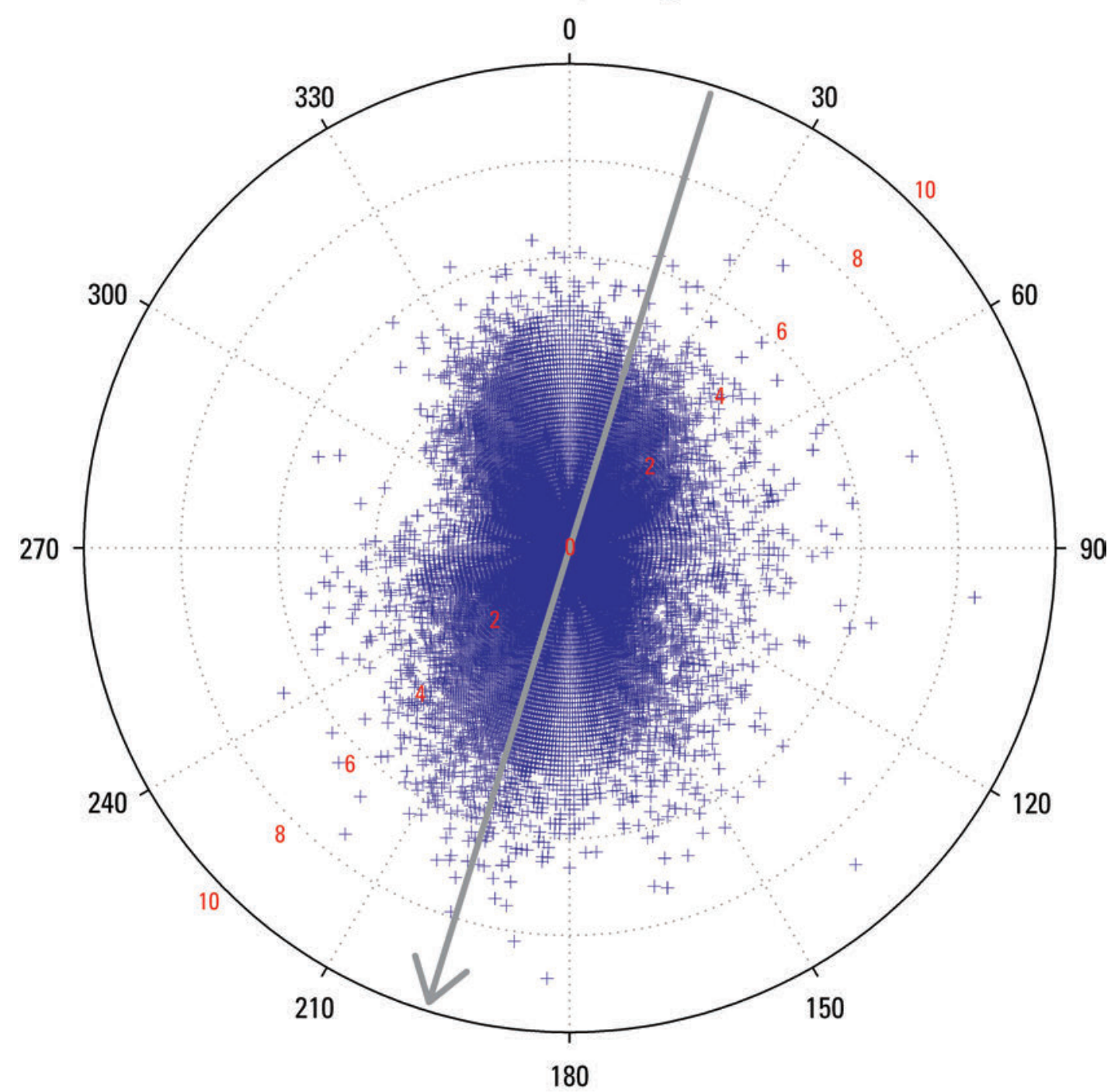

Figure 50. Plot showing magnitude and direction of wind velocity measured at the instrument station AZ A:15:0033 with 4-minute resolution in Grand Canyon, Arizona, 2010. Magnitude is indicated by the concentric circles, and compass bearing indicates the wind direction. The gray arrow shows the orientation of the river corridor $\left(197^{\circ}\right)$; river flow is toward the northwest. 


\section{Station AZ A:15:0033}

Cumulative rainfall

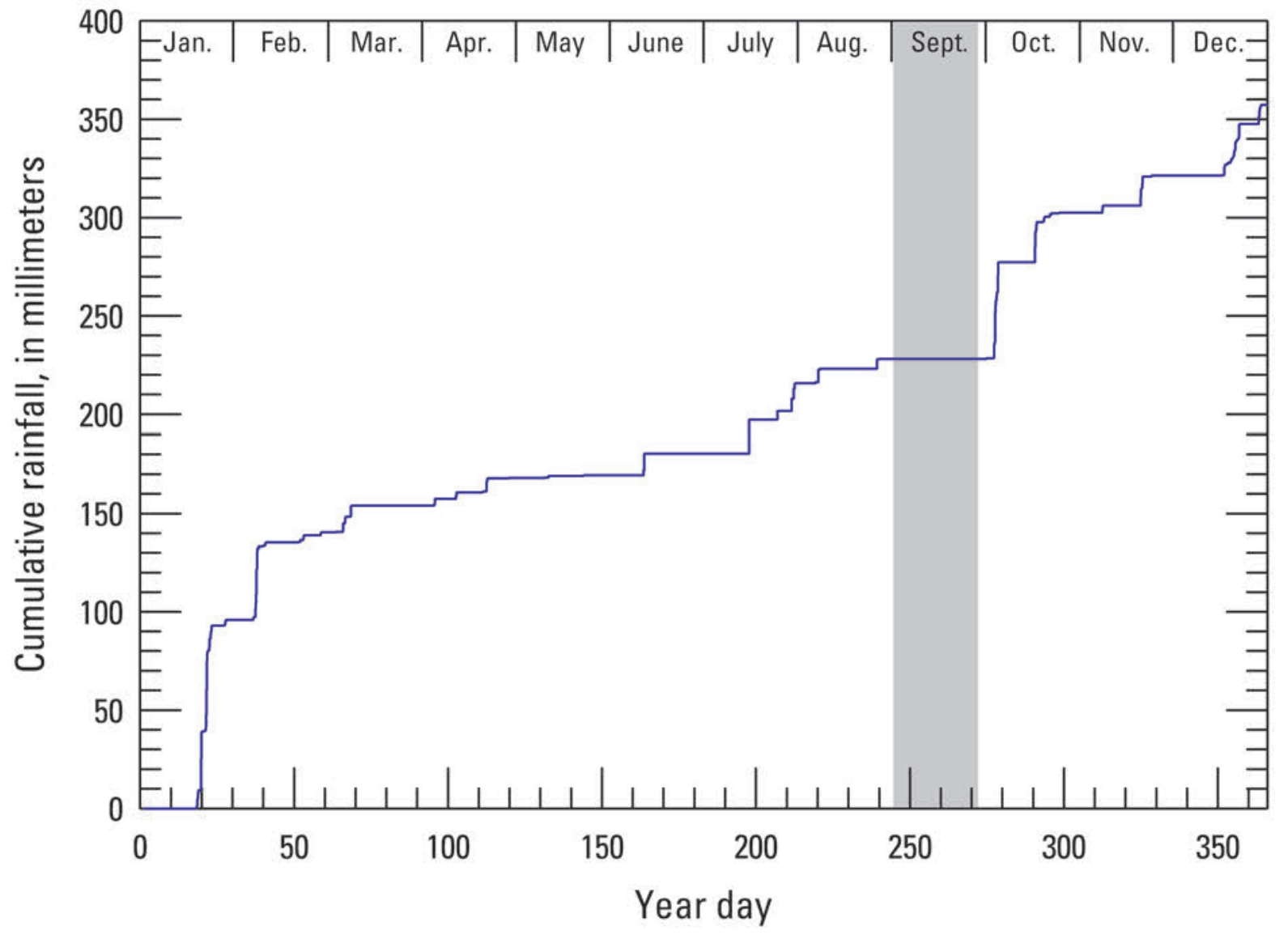

Figure 51. Plot showing cumulative rainfall recorded at site AZ A:15:0033 compiled from data collected at 4minute resolution in Grand Canyon, Arizona, 2010. Gray shading indicates that station malfunction occurred between September 2 and 29, 2010, during which period no data were collected. 
2009
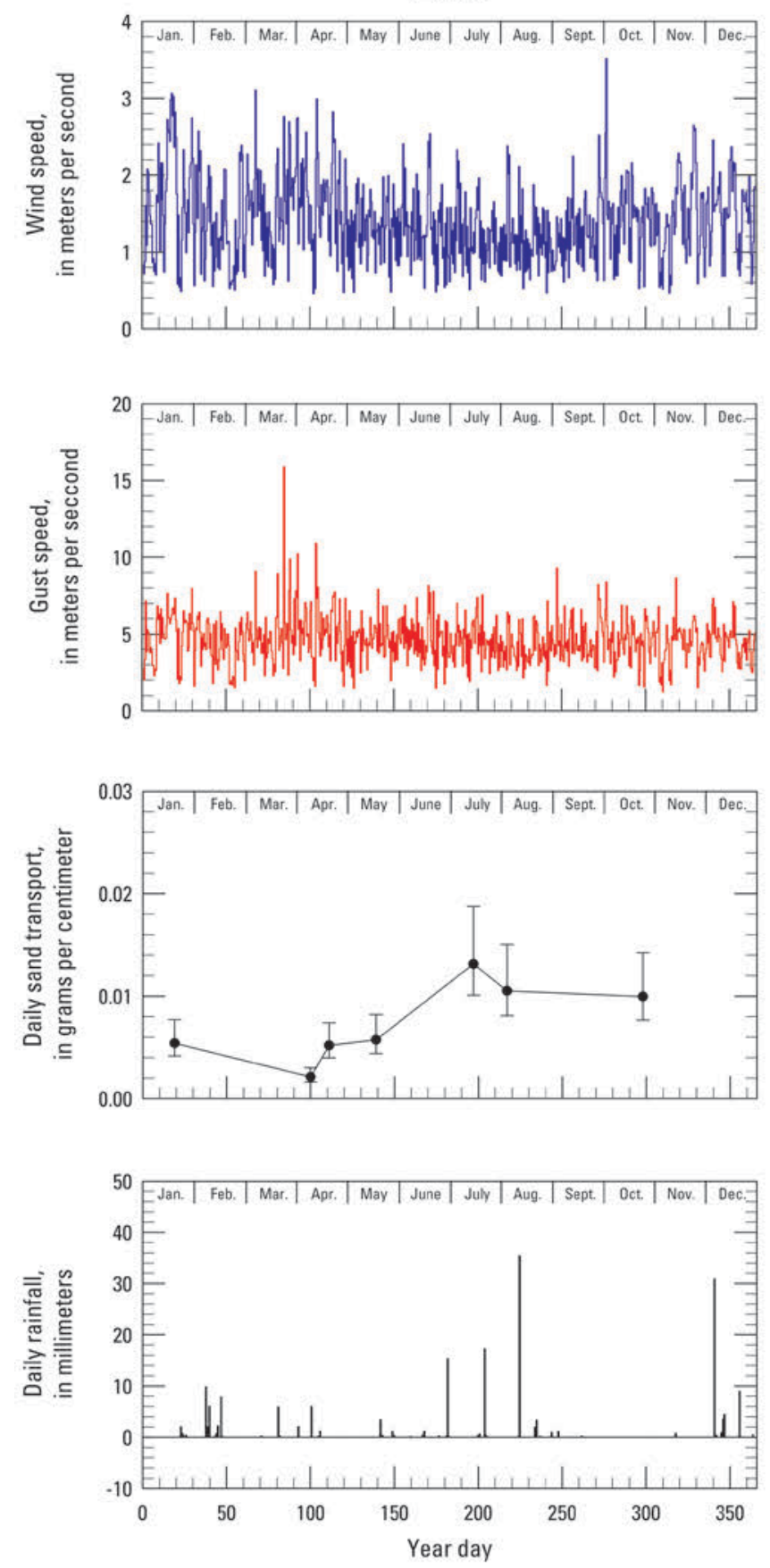

2010
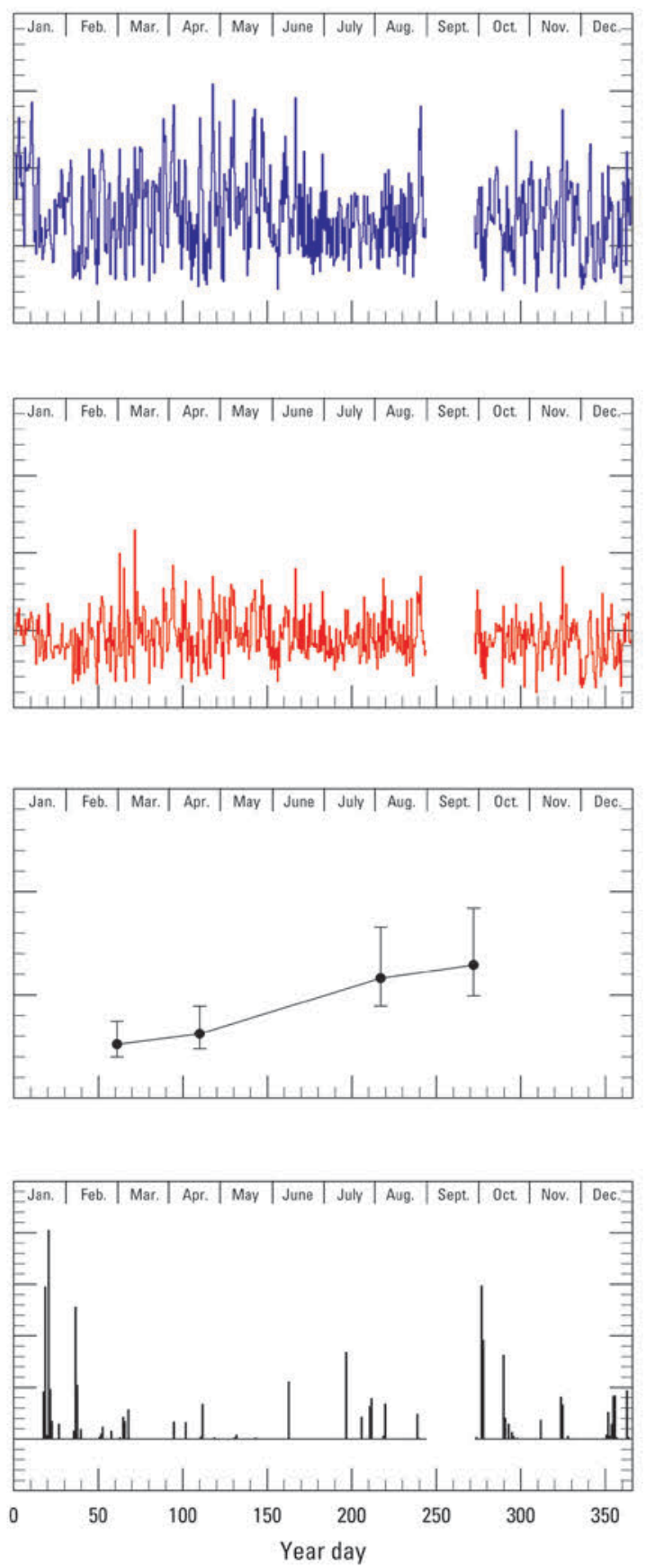

Figure 52. Plots showing wind, aeolian sand-transport, and rainfall data collected at the instrument station AZ A:15:0033 in Grand Canyon, Arizona, 2009-10. Wind speed is presented as diurnal average values, using daytime (0600-1800 hours) and nighttime (1800-0600 hours) averages of data collected at 4-minute intervals. Gust speed is shown as maximum values that occurred during each diurnal interval. Daily sand transport is plotted in grams, normalized to a width of 1 centimeter. To obtain these values, total sand mass collected from four traps during each maintenance visit was divided by the number of days since the trap had last been emptied. Rainfall is plotted as daily (24-hour) totals. 

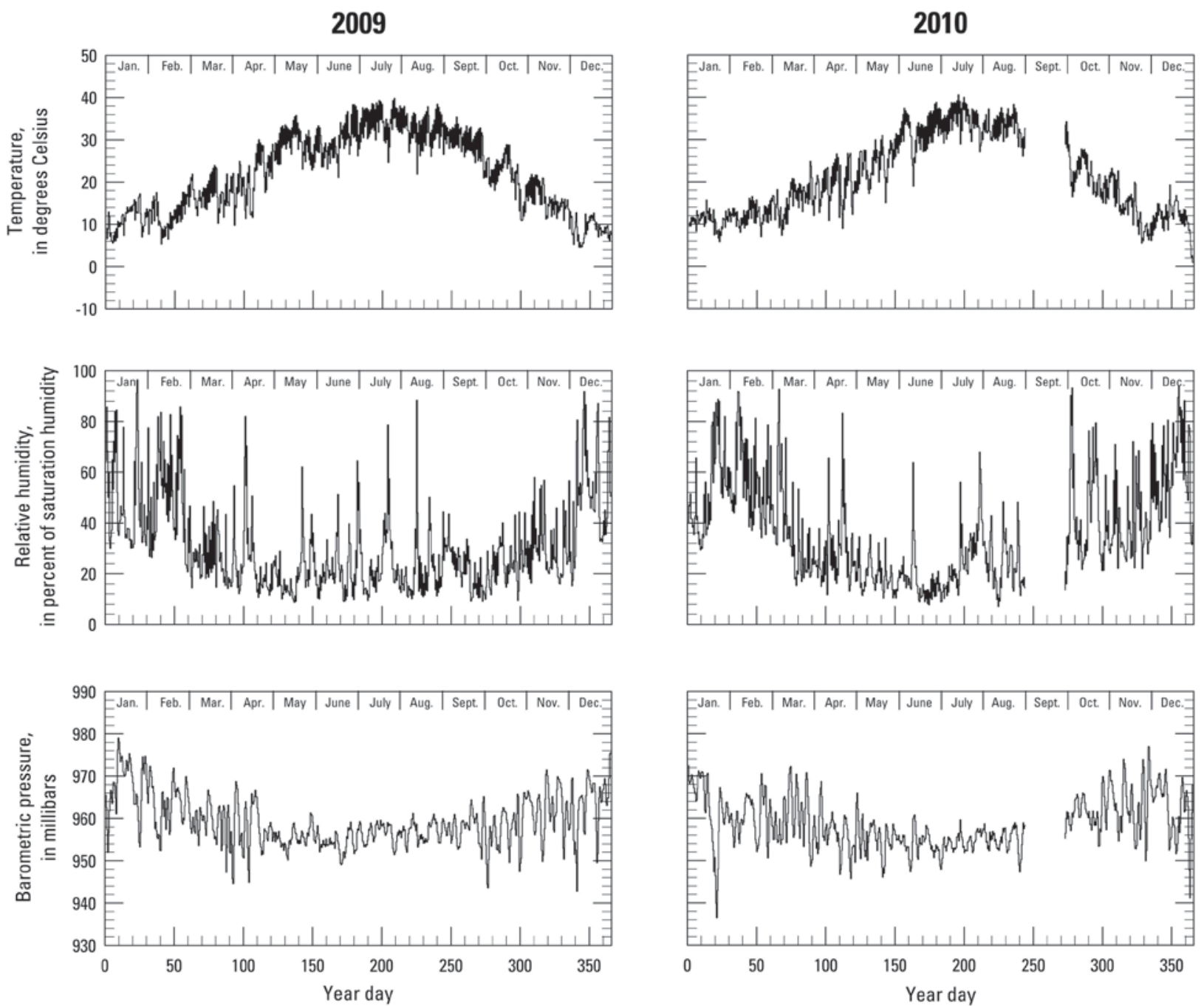

Figure 53. Plots showing temperature, relative humidity, and barometric pressure data collected at instrument station AZ A:15:0033 in Grand Canyon, Arizona, 2009-10. All parameters are plotted as diurnal averages (defined using 0600-1800 and 1800-0600 hours). 
Site AZ G:03:0072

During 2010, one complete instrument station operated at site AZ G:03:0072 (station AZ G:03:0072 U) along with one additional set of sand traps (station AZ G:03:0072 L); equipment locations are shown in figure 54. For unknown reasons, no barometric pressure data were collected by the instrument station at site AZ G:03:0072 between March 2 and June 30, 2010. The weather transmitter was replaced on June 30, and there was no further loss of data. The study sites are on sedimentary deposits that cover the downstream part of a debris fan. Station AZ G:03:0072 U is in an active aeolian dune field that has 49 percent vegetation cover and 6 percent biological soil crust cover near the weather station (Draut, 2011). The sand traps at station AZ G:03:0072 L are lower in elevation and closer to the river than station AZ G:03:0072 U, in an area with nearly 100 percent biological soil crust cover; thick vegetation is present between the lower site and the river (fig. 54). All equipment near site AZ G:03:0072 operated throughout 2010 with no interruptions.

Wind speed and direction measured at station AZ G:03:0072 U in 2010 are plotted in figure 55. Cumulative rainfall data are shown in figure 56; total rainfall measured in 2010 was 294.2 mm (table 2). All weather parameters and sand transport measured at station G:03:0072 U in 2010, and sand transport measured at station AZ G:03:0072 L, are summarized in figures 57 and 58, with 2009 data shown for comparison.

A vector sum of all available wind data from station AZ G:03:0072 U in 2010 yields a net $Q p$ magnitude of $127,970 \mathrm{~m}^{3} / \mathrm{s}^{3}$ from a direction of $198^{\circ}$; using wind data collected only when the sand is estimated to have been dry, a vector sum yields a net $Q p$ magnitude of 103,370 $\mathrm{m}^{3} / \mathrm{s}^{3}$ from a direction of $200^{\circ}$ (table 3). This net flux direction toward upstream reflects a balance between upstream and downstream winds, with a slightly stronger upstream-directed velocity component (figs. 54 and 55). Daily sand-transport rates measured at stations AZ G:03:0072 L and AZ G:03:0072 U were similar (commonly on the order of $0.1 \mathrm{~g} / \mathrm{cm}$ ), and, similar to previous years, showed no substantial increase during the spring (fig. 57), which may be attributed to the presence of vegetation-limiting wind velocities and, therefore, sand-entrainment potential in the area around both sets of sand traps. 


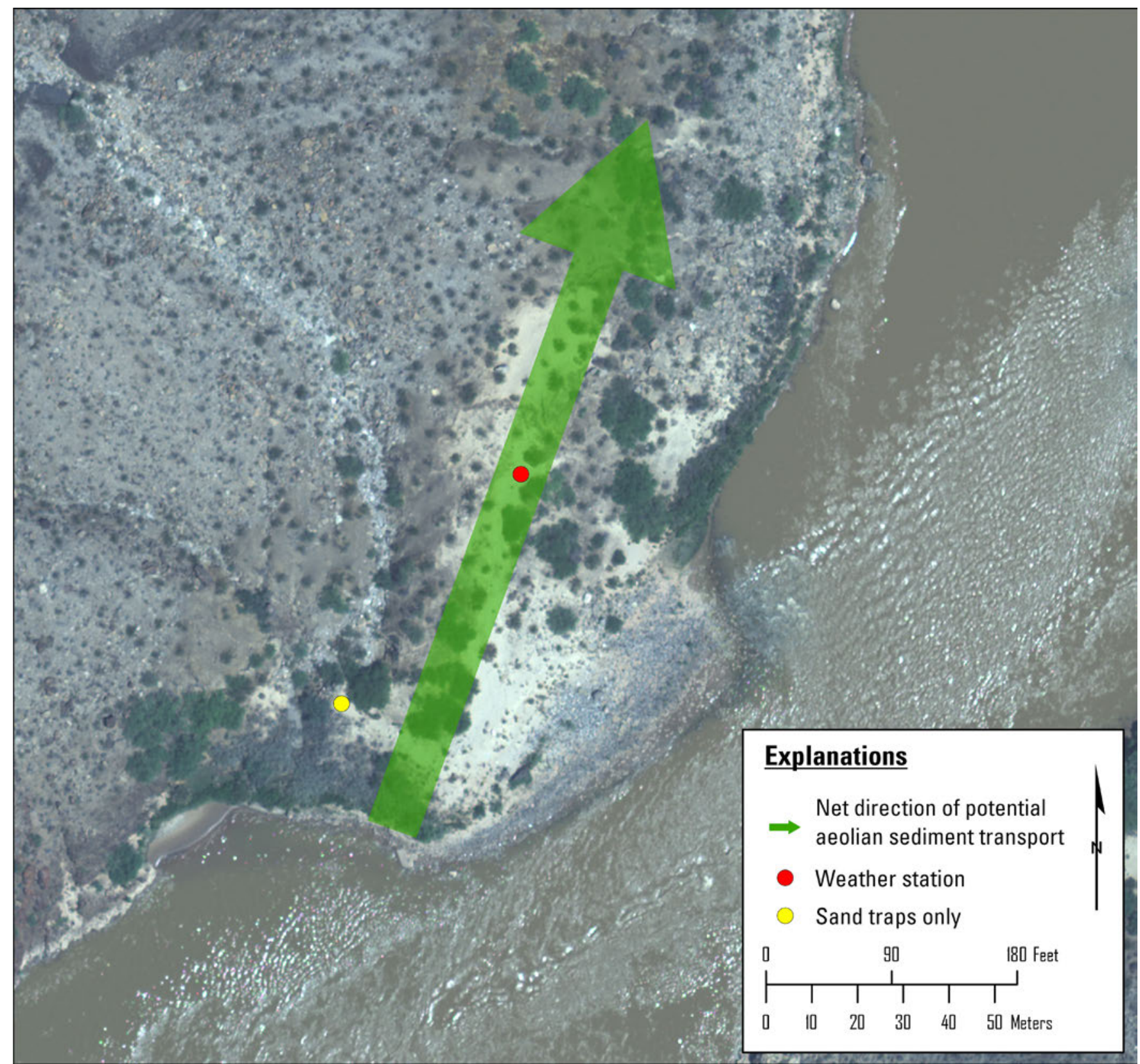

Figure 54. Aerial photograph of the area around site AZ G:03:0072 in Grand Canyon, Arizona. Arrow indicates the net direction of potential aeolian sediment transport measured at AZ G:03:0072 in 2010. A vector sum of the $Q p$ proxy variable (equation 1), calculated using all the wind data collected during dry conditions from AZ G:03:0072 in 2010, indicates net sediment transport from $198^{\circ}$. 


\section{Station AZ G:03:0072 U}

\section{4-minute average wind speed, in meters per second}

and wind direction, in degrees True

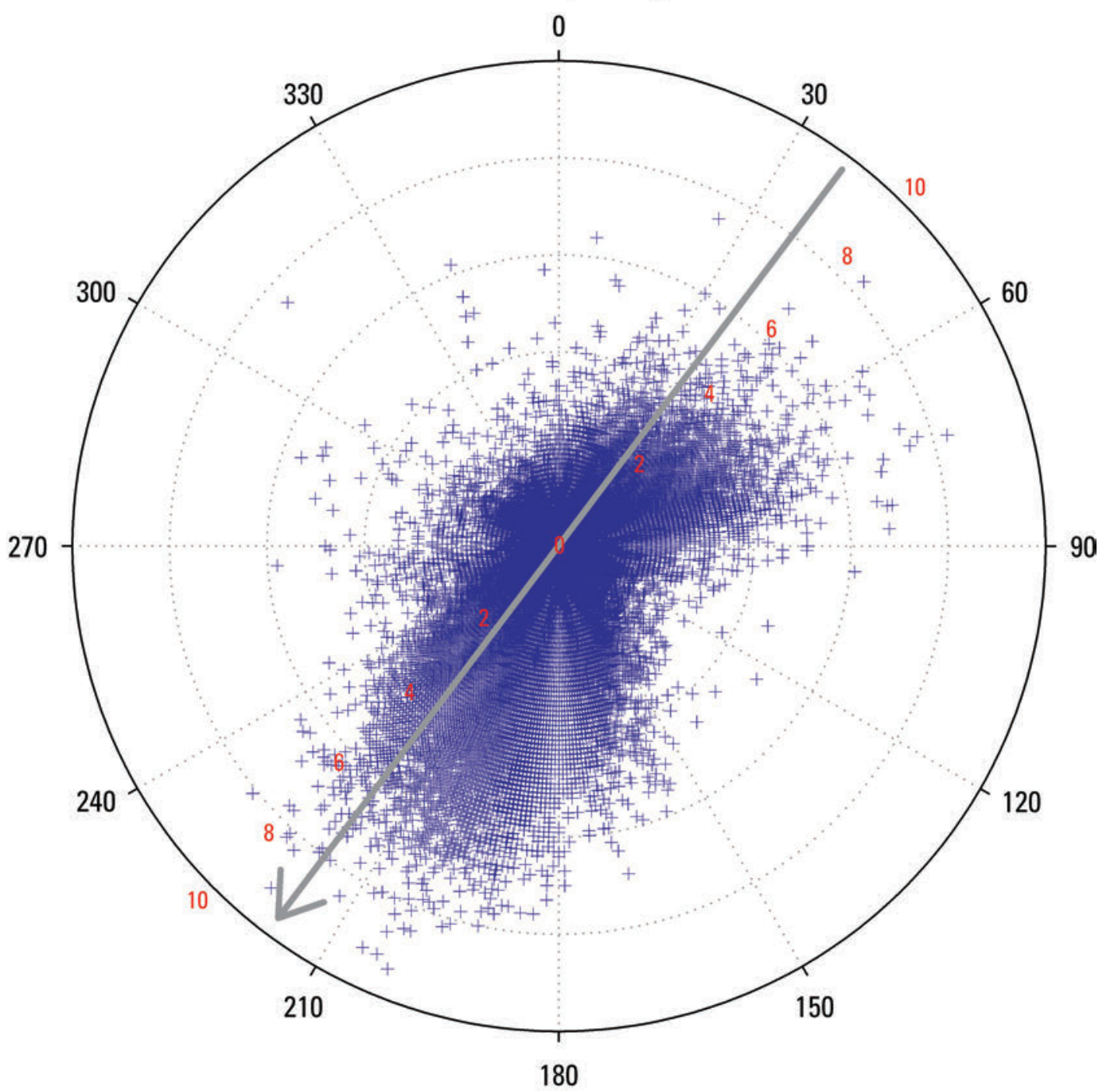

Figure 55. Plot showing magnitude and direction of wind velocity measured at the instrument station $A Z$ G:03:0072 with 4-minute resolution in Grand Canyon, Arizona, 2010. Magnitude is indicated by the concentric circles, and compass bearing indicates the wind direction. The gray arrow shows the orientation of the river corridor $\left(217^{\circ}\right)$; river flow is toward the southwest. 


\section{Station AZ G:03:0072 U}

Cumulative rainfall

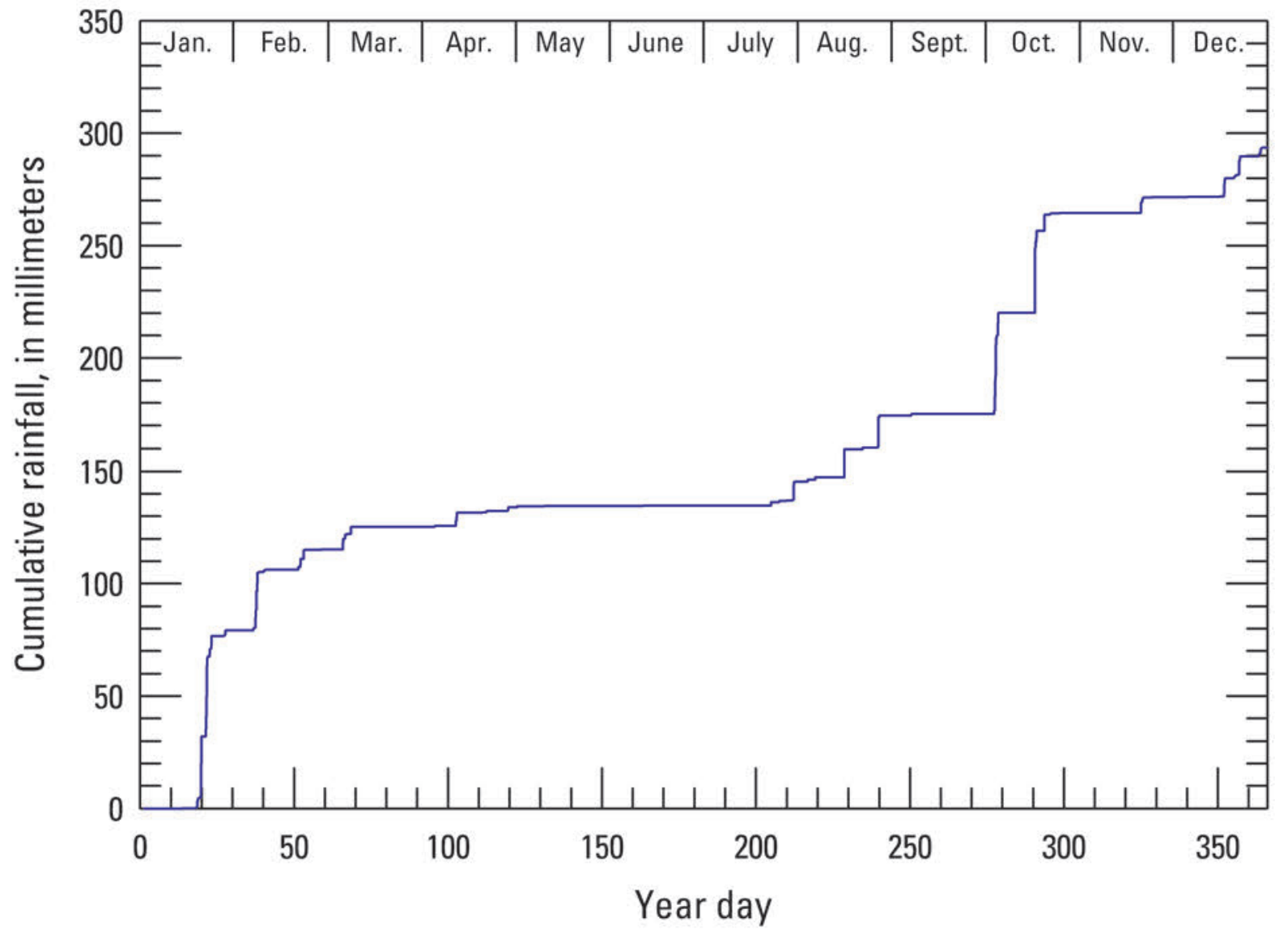

Figure 56. Plot showing cumulative rainfall recorded at site AZ G:03:0072 compiled from data collected at 4minute resolution in Grand Canyon, Arizona, 2010. 
2009
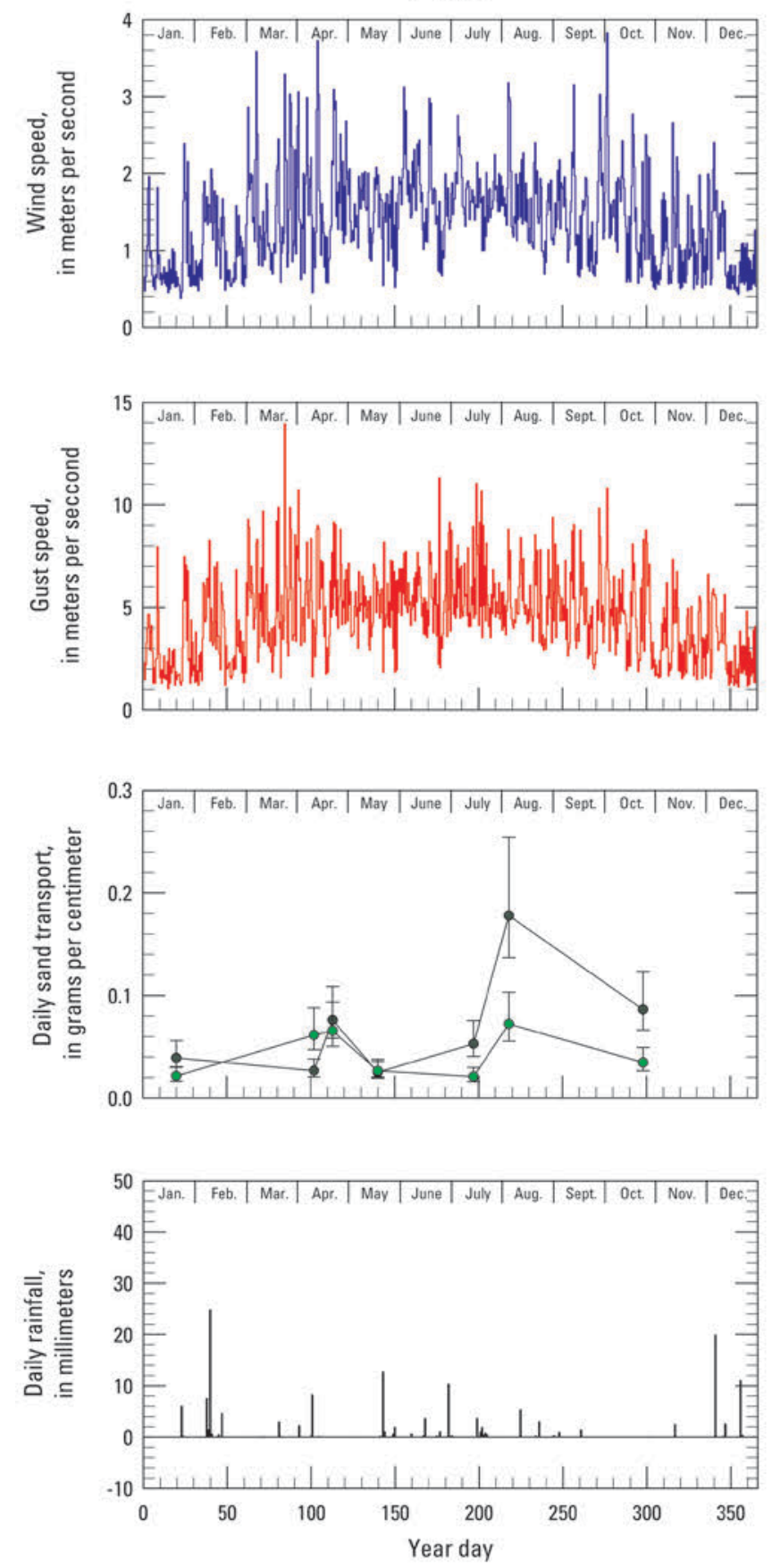

2010
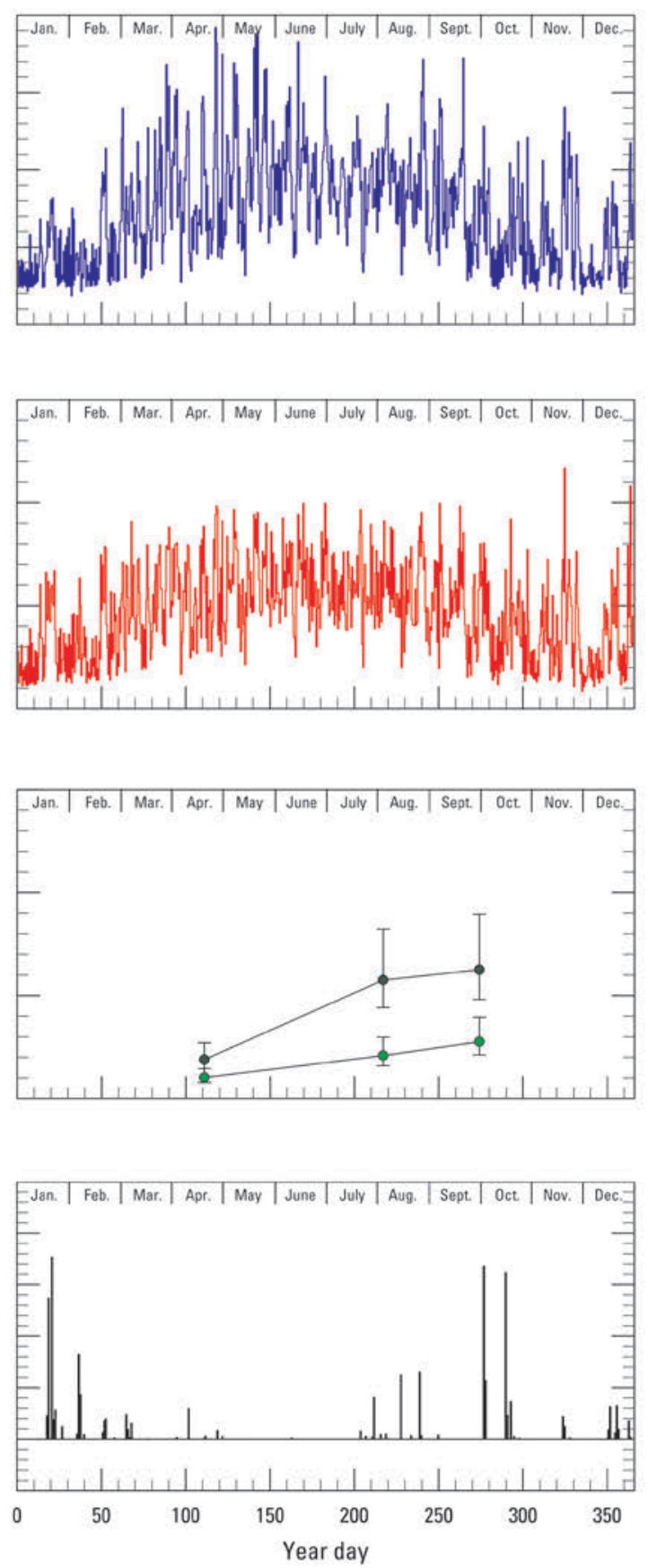

Figure 57. Plots showing wind, aeolian sand-transport, and rainfall data collected at the instrument station AZ G:03:0072 in Grand Canyon, Arizona, 2009-10. Wind speed is presented as diurnal average values, using daytime (0600-1800 hours) and nighttime (1800-0600 hours) averages of data collected at 4-minute intervals. Gust speed is shown as maximum values that occurred during each diurnal interval. Daily sand transport is plotted in grams, normalized to a width of 1 centimeter. To obtain these values, total sand mass collected from four traps during each maintenance visit was divided by the number of days since the trap had last been emptied. The lower of the two sand-transport lines plotted indicates transport rates measured at the lower set of traps at this station (AZ G:03:0072 L). Rainfall is plotted as daily (24-hour) totals. 
2009
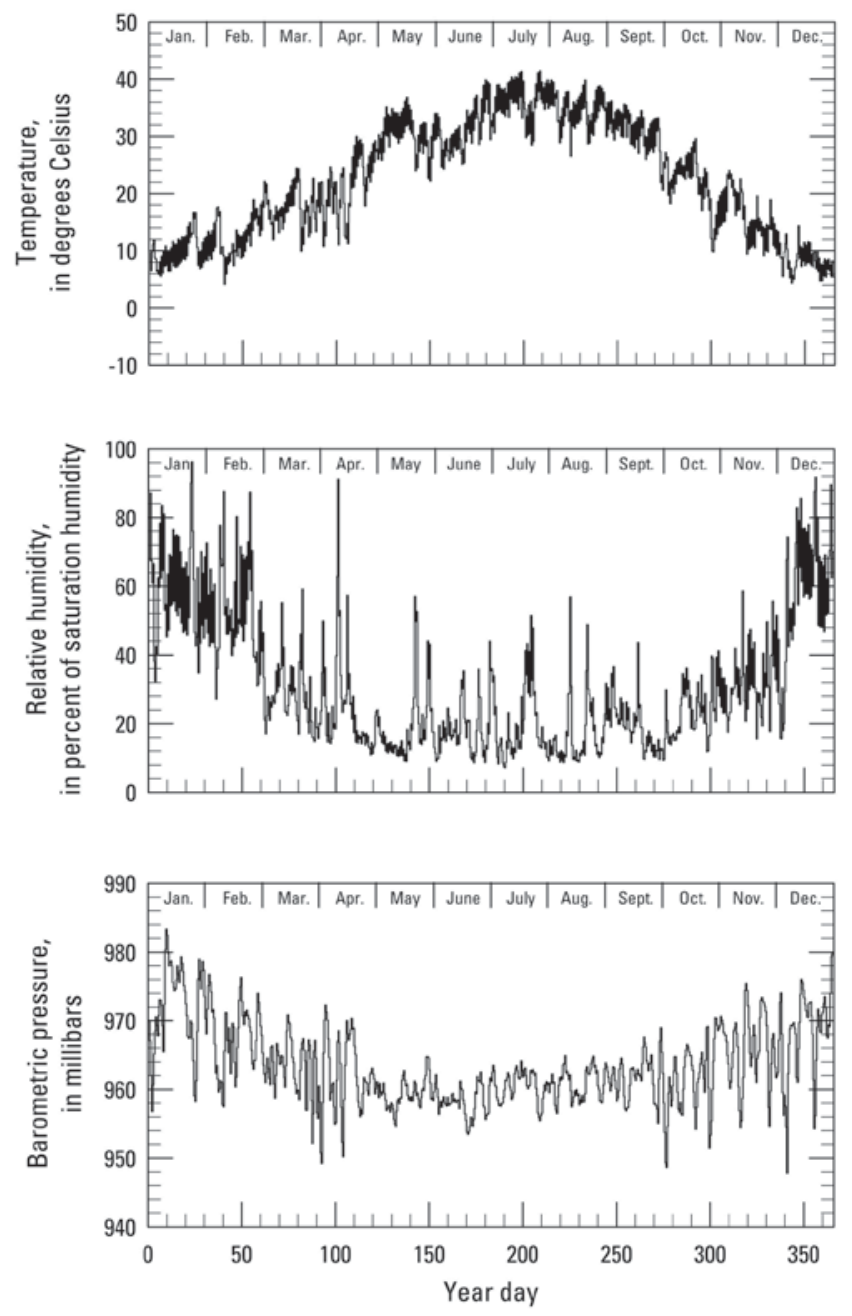

2010
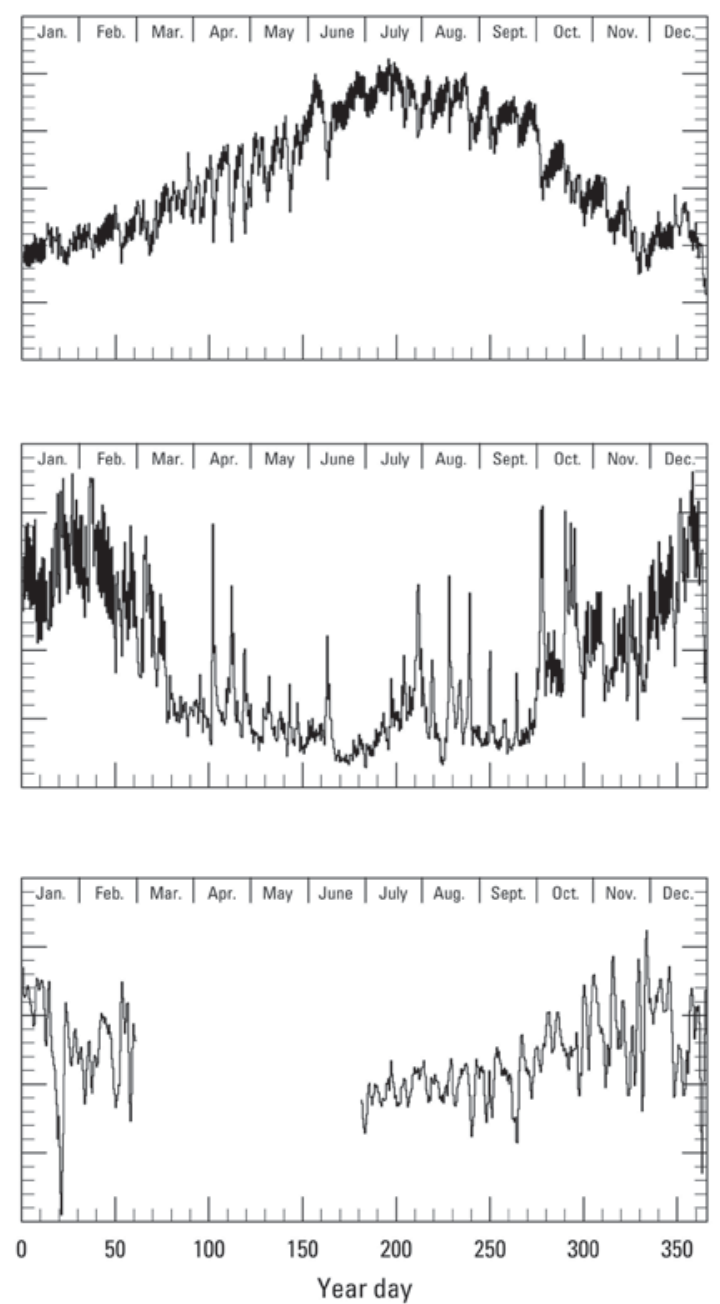

Figure 58. Plots showing temperature, relative humidity, and barometric pressure data collected at instrument station AZ G:03:0072 in Grand Canyon, Arizona, 2009-10. All parameters are plotted as diurnal averages (defined using $0600-1800$ and $1800-0600$ hours).

\section{Discussion}

Collection of weather data at various locations in the Colorado River corridor of Grand Canyon, Arizona, was facilitated in 2009 and 2010 by improved equipment performance compared with 2007 and 2008; however, software updates recommended by Nexsens Technology, Inc. more than tripled the data download times. This increased download time prevented a complete download at station AZ C:13:0346 L in September 2010, resulting in some data being overwritten and, therefore, lost.

At two of the three sites where two stations were deployed (AZ C:13:0005 and AZ C:13:0365), the data showed substantial differences in rainfall between the upper and lower stations (table 2). It is unclear whether the discrepancy between rainfall totals at the upper and lower stations from those two sites is attributable to instrument performance or to actual differences in rainfall over short distances. We consider it more likely a result of instrument performance, given that the rainfall totals were consistently higher at one particular station in each case (AZ C:13:0005 L and AZ C:13:0365 L). At site 
AZ C:13:0346, the two stations recorded comparable rainfall for the events when both stations (AZ C:13:0346 L and AZ C:13:0346 U) were operating.

As in past years, seasonal differences in aeolian sand flux were apparent at most study sites, although the resolution of sand-transport variations depends on the intervals of manual sample collection. Data collected in 2010 also clearly show event- and seasonal-scale variations in rainfall, wind, temperature, humidity, and barometric pressure, some of which were more similar to patterns recorded in 2008 than patterns recorded in 2009. The most notable difference between 2009 and 2010 is the substantially greater overall precipitation recorded in 2010, particularly in the spring and fall. Precipitation amounts recorded in 2010 were approximately double the amounts recorded in 2009.

A later spring windy season also was notable in 2010 (April-May 2010 in contrast to MarchApril 2009), as were later onset of the reduced diurnal barometric-pressure fluctuations commonly associated with summer monsoon conditions (which began in late May 2010 in contrast to having begun in late April in 2009). Weather patterns in early to mid-2010 were affected by El Niño conditions during spring, whereas the patterns in late 2010 were affected by a delayed transition to an El Niño-Southern Oscillation (ENSO) neutral phase (National Climatic Data Center, 2012). These changes in the cycle presumably were responsible for the greater rainfall in Grand Canyon in 2010 compared to 2009. The increased rainfall in Grand Canyon in 2010 compared to 2009 is consistent with measurements elsewhere in Arizona (for example, Draut and others, 2012), with 2009 having been an exceptionally dry year-Arizona's fourth driest year in the 117 years in which records have been kept, with below-normal rainfall statewide (National Climatic Data Center, 2012). In contrast, 2010 was Arizona's 85th driest year on record, with above-normal rainfall statewide (National Climatic Data Center, 2012); although northeastern Arizona received below-average rainfall in 2010, the summer monsoon of 2010 nevertheless brought substantial rainfall to the Grand Canyon region, as the data in this report show (also see Draut and others, 2012).

The quantitative methods and data discussed here form a basis for monitoring ecosystem processes that affect archeological site stability. Combined with ongoing work by other researchers to evaluate landscape evolution at nearby archeological sites (for example, Collins and others, 2012), these data can be used to document the relation between physical processes, including weather and aeolian sand transport, and the stability of archeological sites. Such a comparison is the subject of a new study supported by the Glen Canyon Dam Adaptive Management Program and initiated in 2013 (Fairley and others, 2012), which builds on earlier work by Fairley and others (1994), Neal and others (2000), Thompson and Potochnik (2000), Collins and others (2012), and Draut (2012), linking weather data, geomorphic processes and landscape change on a large scale with measurements of smaller-scale effects at individual archeological sites.

\section{Conclusions}

This report presents meteorological and aeolian sand-transport data collected at weather stations in the Colorado River corridor through Grand Canyon National Park in 2010. Compared to 2009, measurements from 2010 included a slightly later spring windy season, greater spring precipitation and annual rainfall totals, and a later onset and length of the reduced diurnal barometric-pressure fluctuations commonly associated with summer monsoon conditions. The increase in spring precipitation was consistent with the 2010 spring El Niño conditions compared to the 2009 spring La Niña conditions, whereas the subsequent transition to an El Niño-Southern Oscillation neutral phase apparently delayed the reduction in diurnal barometric fluctuations. These data provide the basis for understanding landscape change that can affect archaeological sites and their surrounding environment. 


\section{Acknowledgments}

This study is supported by funding from the Bureau of Reclamation through the U.S. Geological Survey (Grand Canyon Monitoring and Research Center). Weather station maintenance also was facilitated through cooperation with the non-profit organization, Grand Canyon Youth of Flagstaff, Arizona.

\section{References Cited}

Bagnold, R.A., 1941, The physics of blown sand and desert dunes (4th ed.): London, Chapman and Hall, 265 p.

Bressolier, C., and Thomas, Y.-F., 1977, Studies on wind and plant interactions on French Atlantic coastal dunes: Journal of Sedimentary Petrology, v. 47, p. 331-338.

Buckley, R., 1987, The effect of sparse vegetation on the transport of dune sand by wind: Nature, v. 325, p. 426-428.

Collins, B.D., Corbett, S.C., Fairley, H.C., Minasian, D., Kayen, R., Dealy, T.P., and Bedford, D.R., 2012, Topographic change detection at select archeological sites in Grand Canyon National Park, Arizona, 2007-2010: U.S. Geological Survey Scientific Investigations Report 2012-5133, 77 p., http://pubs.usgs.gov/sir/2012/5133/.

Collins, B.D., Minasian, D., and Kayen, R., 2009, Topographic change detection at select archeological sites in Grand Canyon National Park, Arizona, 2006-2007: U.S. Geological Survey Scientific Investigations Report 2009-5116, 58 p., http://pubs.usgs.gov/sir/2009/5116/.

Draut, A.E., 2011, Vegetation and substrate properties of aeolian dune fields in the Colorado River corridor, Grand Canyon, Arizona: U.S. Geological Survey Open-File Report 2011-1195, 16 p. and 28 tables, http://pubs.usgs.gov/of/2011/1195/.

Draut, A.E., 2012, Effects of river regulation on aeolian landscapes, Colorado River, southwestern USA: Journal of Geophysical Research, Earth Surface, v. 117, F2, doi:10.1029/2011JF002329.

Draut, A.E., Andrews, T., Fairley, H.C., and Brown, C.R., 2009a, 2007 weather and aeolian sandtransport data from the Colorado River corridor, Grand Canyon, Arizona: U.S. Geological Survey Open-File Report 2009-1098, 110 p., http://pubs.usgs.gov/of/2009/1098/.

Draut, A.E., Redsteer, M.H., and Amoroso, L., 2012, Vegetation, substrate, and aeolian sediment transport at Teesto Washington, Navajo Nation, 2009-12: U.S. Geological Survey Scientific Investigations Report 2012-5095, 71 p., http://pubs.usgs.gov/of/2011/1195/.

Draut, A.E., and Rubin, D.M., 2005, Measurements of wind, aeolian, sand transport, and precipitation in the Colorado River corridor, Grand Canyon, Arizona-November 2003 to December 2004: U.S. Geological Survey Open-File Report 2005-1309, 70 p., http://pubs.usgs.gov/of/2005/1309/.

Draut, A.E., and Rubin, D.M., 2006, Measurements of wind, aeolian, sand transport, and precipitation in the Colorado River corridor, Grand Canyon, Arizona-January 2005 to January 2006: U.S. Geological Survey Open-File Report 2006-1188, 88 p., http://pubs.usgs.gov/of/2006/1188/.

Draut, A.E., and Rubin, D.M., 2007, The role of aeolian sediment in the preservation of archaeological sites in the Colorado River corridor, Grand Canyon, Arizona-Final report on research activities, 2003-2006: U.S. Geological Survey Open-File Report 2007-1001, 141 p., http://pubs.usgs.gov/of/2007/1001/.

Draut, A.E., and Rubin, D.M., 2008, The role of aeolian sediment in the preservation of archaeological sites along the Colorado River corridor in Grand Canyon National Park, Arizona: U.S. Geological Survey Professional Paper 1756, 79 p., http://pubs.usgs.gov/pp/1756/.

Draut, A.E., Sondossi, H.A., Dealy, T.P., Hazel, J.E., Jr., Fairley, H.C., and Brown, C.R., 2010, 2009 weather and aeolian sand-transport data from the Colorado River corridor, Grand Canyon, Arizona: U.S. Geological Survey Open-File Report 2010-1166, 98 p., http://pubs.usgs.gov/of/2010/1166/. 
Draut, A.E., Sondossi, H.A., Hazel, J.E., Jr., Andrews, T., Fairley, H.C., Brown, C.R., and Vanaman, K.M., 2009b, 2008 weather and aeolian sand-transport data from the Colorado River corridor, Grand Canyon, Arizona: U.S. Geological Survey Open-File Report 2009-1190, 98 p., http://pubs.usgs.gov/of/2009/1190/.

Fairley, H.C., Bungart, P.W., Coder, C.M., Huffman, J., Samples, T.L., and Balsom, J.R., 1994, The Grand Canyon river corridor survey project-Archaeological survey along the Colorado River between Glen Canyon Dam and Separation Canyon: Prepared in cooperation with the Glen Canyon Environmental Studies Program, National Park Service cooperative agreement no. 9AA-40-07920, 153 p.

Fairley, H.C., Collins, B., Draut, A., Leap, L., O’Brien, G. and Pederson, J., 2007, FY07-FY11 Archaeological site monitoring research and development project: National Park Service Research and Collecting Permit Proposal submitted to Grand Canyon National Park, August 8, 2007, 99 p.

Fairley, H.C., Draut, A., Collins, B., Corbett, S., Bedford, D., Davis, P., and Sankey, J., 2012, Project $\mathrm{J}$-Monitoring cultural resources at a small scale and defining the large-scale geomorphic context of the processes affecting cultural resources, in Bureau of Reclamation and U.S. Geological Survey, Glen Canyon Dam adaptive management program biennial budget and work plan-Fiscal years 2013-14: Bureau of Reclamation and U.S. Geological Survey, p. 220-268, accessed February 17, 2014, at http://www.usbr.gov/uc/rm/amp/amwg/mtgs/12aug29/Attach_08b.pdf.

Fairley, H.C., and Sondossi, H., 2010, Applying an ecosystem framework to evaluate archaeological site condition along the Colorado River in Grand Canyon National Park, Arizona, in Melis, T.S., Hamill, J.F., Coggins, L.G., Jr., Grams, P.E., Kennedy, T.A., Kubly, D.M., and Ralston, B.E., eds., Proceedings of the Colorado River Basin Science and Resource Management Symposium, November 18-20, 2008, Scottsdale, Arizona: U.S. Geological Survey Scientific Investigations Report 2010-5135, p. 333-341, http://pubs.usgs.gov/sir/2010/5135/.

Fryrear, D.W., 1986, A field dust sampler: Journal of Soil and Water Conservation, v. 41, no. 2, p. 117120.

Goossens, D., Offer, Z.Y., and London, G., 2000, Wind tunnel and field calibration of five aeolian dust samplers: Geomorphology, v. 35, p. 232-252.

Hazel, J.E., Jr., Kaplinski, M., Parnell, R.A., and Fairley, H.C., 2008, Aggradation and degradation of the Palisades gully network, 1996 to 2005, with emphasis on the November 2004 high-flow experiment, Grand Canyon National Park, Arizona: U.S. Geological Survey Open-File Report 20081264, 14 p., http://pubs.usgs.gov/of/2008/1264/.

Hereford, R., Fairley, H.C., Thompson, K.S., and Balsom, J.R., 1993, Surficial geology, geomorphology, and erosion of archeologic sites along the Colorado River, eastern Grand Canyon, Grand Canyon National Park, Arizona: U.S. Geological Survey Open-File Report 93-517, 46 p., http://pubs.er.usgs.gov/publication/ofr93517.

Hereford, R., Thompson, K.S., Burke, K.J., and Fairley, H.C., 1996, Tributary debris fans and the late Holocene alluvial chronology of the Colorado River, eastern Grand Canyon, Arizona: Geological Society of America Bulletin, v. 108, p. 3-19.

Huntoon, P., 2003, Post-Precambrian tectonism in the Grand Canyon region, in Beus, S.S., and Morales, M., eds., Grand Canyon geology (2d ed.): New York, Oxford University Press, p. 222-259.

Kawamura, R., 1951, Study of sand movement by wind: University of Tokyo, Institute of Science and Technology Report, v. 5 nos. 3-4, p. 95-112 [in Japanese].

Lettau, K., and Lettau, H.H., 1977, Experimental and micro-meteorological field studies of dune migration, in Lettau, H.H., and Lettau, K., eds., Exploring the world's driest climates: Madison, University of Wisconsin, Institute of Environmental Science Report 101, p. 110-147. 
Magirl, C.S., Breedlove, M.J., Webb, R.H., and Griffiths, P.G., 2008, Modeling water-surface elevations and virtual shorelines for the Colorado River in Grand Canyon, Arizona: U.S. Geological Survey Scientific Investigations Report 2008-5075, 40 p., http://pubs.usgs.gov/sir/2008/5075/.

National Climatic Data Center, 2012, State of the climate National overview: National Oceanic and Atmospheric Administration, accessed June 20, 2012, at http://www.ncdc.noaa.gov.

Neal, L.A., Gilpin, D., Jonas, L., and Ballagh, J.H., 2000, Cultural resources data synthesis within the Colorado River corridor, Grand Canyon National Park and Glen Canyon National Recreation Area, Arizona: SWCA, Inc., Cultural Resources Report 98-85.

Nickling, W.G., and Neuman, M.C., 1997, Wind tunnel evaluation of a wedge-shaped aeolian sediment trap: Geomorphology, v. 18, p. 333-345.

O’Brien, G., and Pederson, J., 2009, Gully erosion processes and parameters and six cultural sites along the Colorado River in Grand Canyon National Park, Arizona-Final report: Utah State University and U.S. Geological Survey, Grand Canyon Monitoring and Research Center, cooperative agreement 04HQAG0122 and subagreement 04122HS010, 126 p. (Internal report available on request from the Grand Canyon Monitoring and Research Center, Flagstaff, Arizona.)

Saunders, S., Montgomery, C., Easley, T., and Spencer, T., 2008, Hotter and drier-The west's changing climate: New York, Rocky Mountain Climate Organization and Natural Resources Defense Council, $54 \mathrm{p}$.

Schmidt, J.C., and Graf, J.B., 1990, Aggradation and degradation of alluvial sand deposits, 1965-1986, Colorado River, Grand Canyon National Park, Arizona: U.S. Geological Survey Professional Paper 1493, 74 p, http://pubs.er.usgs.gov/publication/pp1493.

Stout, J.E., and Fryrear, D.W., 1989, Performance of a windblown-particle sampler: American Society of Agricultural Engineers Transactions, v. 32, p. 2041-2045.

Thompson, K.S., and Potochnik, A.R., 2000, Development of a geomorphic model to predict erosion of pre-dam Colorado River terraces containing archaeological resources: SWCA, Inc. Cultural Resources Report 99-257.

Vaisala, 2008, Vaisala weather transmitter WXT520_-Vaisala User’s Guide: Helsinki, Finland, Vaisala, $166 \mathrm{p}$.

Vaisala, [n.d.], Vaisala RAINCAP ${ }^{\circledR}$ sensor technology: Helsinki, Finland, Vaisala Web site, accessed February 27, 2014, at http://http://www.vaisala.com/.

Yeatts, M., 1996, High elevation sand deposition and retention from the 1996 spike flow-An assessment for cultural resources stabilization, in Balsom, J.R., and Larralde, S., eds., Mitigation and monitoring of cultural resources in response to the experimental habitat building flow in Glen and Grand Canyons, Spring 1996: Flagstaff, Arizona, Report to Bureau of Reclamation, and Grand Canyon Monitoring and Research Center, p. 124-158. (Internal report available on request from the Grand Canyon Monitoring and Research Center, Flagstaff, Arizona.)

Zobeck, T.M., Sterk, G., Funk, R., Rajot, J.L., Stout, J.E., and Van Pelt, R.S., 2003, Measurement and data analysis methods for field-scale wind erosion studies and model validation: Earth Surface Processes and Landforms, v. 28, p. 1163-1188. 
Table 2. Total rainfall, in millimeters, recorded daily by each weather station.

\begin{tabular}{|c|c|c|c|c|c|c|c|c|c|c|c|c|}
\hline $\begin{array}{l}\text { Date } \\
(2010)\end{array}$ & $\begin{array}{c}\mathrm{AZ} \\
\mathrm{C}: 05: 0031 \\
\mathrm{U}\end{array}$ & $\begin{array}{c}A Z \\
\text { C:05:0031 } \\
L\end{array}$ & $\begin{array}{c}A Z \\
C: 13: 0365 \\
U\end{array}$ & $\begin{array}{c}A Z \\
C: 13: 0365 \\
L\end{array}$ & $\begin{array}{c}A Z \\
C: 13: 0006\end{array}$ & $\begin{array}{c}A Z \\
C: 13: 0336 \\
U\end{array}$ & $\begin{array}{c}A Z \\
C: 13: 0346 \\
U\end{array}$ & $\begin{array}{c}A Z \\
C: 13: 0346 \\
L\end{array}$ & $\begin{array}{c}A Z \\
B: 11: 0281\end{array}$ & $\begin{array}{c}A Z \\
A: 15: 0033\end{array}$ & $\begin{array}{c}A Z \\
\text { G:03:0072 } \\
U\end{array}$ & $\begin{array}{l}\text { Year } \\
\text { day }\end{array}$ \\
\hline $1 / 1$ & 0.00 & 0.00 & 0.00 & 0.00 & 0.00 & 0.00 & 0.00 & 0.00 & 0.00 & 0.00 & 0.00 & 1 \\
\hline $1 / 2$ & 0.00 & 0.00 & 0.00 & 0.00 & 0.00 & 0.00 & 0.00 & 0.00 & 0.00 & 0.00 & 0.00 & 2 \\
\hline $1 / 3$ & 0.00 & 0.00 & 0.00 & 0.00 & 0.00 & 0.00 & 0.00 & 0.00 & 0.00 & 0.00 & 0.00 & 3 \\
\hline $1 / 4$ & 0.00 & 0.00 & 0.00 & 0.00 & 0.00 & 0.00 & 0.00 & 0.00 & 0.00 & 0.00 & 0.00 & 4 \\
\hline $1 / 5$ & 0.00 & 0.00 & 0.00 & 0.00 & 0.00 & 0.00 & 0.00 & 0.00 & 0.00 & 0.00 & 0.00 & 5 \\
\hline $1 / 6$ & 0.00 & 0.00 & 0.00 & 0.00 & 0.00 & 0.00 & 0.00 & 0.00 & 0.00 & 0.00 & 0.00 & 6 \\
\hline $1 / 7$ & 0.00 & 0.00 & 0.00 & 0.00 & 0.00 & 0.00 & 0.00 & 0.00 & 0.00 & 0.00 & 0.00 & 7 \\
\hline $1 / 8$ & 0.00 & 0.00 & 0.00 & 0.00 & 0.00 & 0.00 & 0.00 & 0.00 & 0.00 & 0.00 & 0.00 & 8 \\
\hline $1 / 9$ & 0.00 & 0.00 & 0.00 & 0.00 & 0.00 & 0.00 & 0.00 & 0.00 & 0.00 & 0.00 & 0.00 & 9 \\
\hline $1 / 10$ & 0.00 & 0.00 & 0.00 & 0.00 & 0.00 & 0.00 & 0.00 & 0.00 & 0.00 & 0.00 & 0.00 & 10 \\
\hline $1 / 11$ & 0.00 & 0.00 & 0.00 & 0.00 & 0.00 & 0.00 & 0.00 & 0.00 & 0.00 & 0.00 & 0.00 & 11 \\
\hline $1 / 12$ & 0.00 & 0.00 & 0.00 & 0.00 & 0.00 & 0.00 & 0.00 & 0.00 & 0.00 & 0.00 & 0.00 & 12 \\
\hline $1 / 13$ & 0.00 & 0.00 & 0.00 & 0.00 & 0.03 & 0.15 & 0.00 & 0.03 & 0.00 & 0.00 & 0.08 & 13 \\
\hline $1 / 14$ & 0.00 & 0.00 & 0.00 & 0.00 & 0.00 & 0.00 & 0.00 & 0.00 & 0.00 & 0.00 & 0.00 & 14 \\
\hline $1 / 15$ & 0.00 & 0.00 & 0.00 & 0.00 & 0.00 & 0.00 & 0.00 & 0.00 & 0.00 & 0.00 & 0.00 & 15 \\
\hline $1 / 16$ & 0.00 & 0.00 & 0.00 & 0.00 & 0.00 & 0.00 & 0.00 & 0.00 & 0.00 & 0.00 & 0.00 & 16 \\
\hline $1 / 17$ & 0.00 & 0.00 & 0.00 & 0.00 & 0.00 & 0.00 & 0.00 & 0.00 & 0.00 & 0.00 & 0.00 & 17 \\
\hline $1 / 18$ & 0.46 & 0.43 & 3.63 & 4.57 & 5.59 & 2.44 & 2.34 & 2.11 & 5.41 & 9.17 & 4.52 & 18 \\
\hline $1 / 19$ & 4.57 & 4.62 & 2.87 & 2.90 & 3.76 & 2.95 & 2.18 & 2.01 & 17.17 & 29.51 & 27.41 & 19 \\
\hline $1 / 20$ & 2.95 & 2.97 & 1.12 & 1.27 & 1.35 & 0.84 & 0.48 & 0.36 & 0.20 & 0.69 & 0.00 & 20 \\
\hline $1 / 21$ & 14.81 & 18.08 & 33.40 & 35.79 & 25.93 & 26.52 & 22.81 & 22.99 & 33.25 & 40.46 & 35.31 & 21 \\
\hline $1 / 22$ & 3.00 & 3.48 & 7.77 & 9.12 & 4.14 & 0.23 & 0.20 & 0.23 & 5.31 & 9.68 & 3.78 & 22 \\
\hline $1 / 23$ & 0.18 & 0.20 & 0.03 & 0.00 & 0.03 & 0.03 & 0.00 & 0.00 & 10.39 & 3.43 & 5.66 & 23 \\
\hline $1 / 24$ & 0.00 & 0.00 & 0.00 & 0.00 & 0.00 & 0.00 & 0.00 & 0.00 & 0.00 & 0.00 & 0.00 & 24 \\
\hline $1 / 25$ & 0.00 & 0.00 & 0.00 & 0.00 & 0.00 & 0.00 & 0.00 & 0.00 & 0.00 & 0.00 & 0.00 & 25 \\
\hline $1 / 26$ & 0.00 & 0.00 & 0.00 & 0.00 & 0.00 & 0.00 & 0.00 & 0.00 & 0.00 & 0.00 & 0.00 & 26 \\
\hline $1 / 27$ & 2.18 & 2.44 & 1.52 & 1.47 & 1.02 & 0.43 & 0.53 & 0.53 & 0.97 & 2.87 & 2.39 & 27 \\
\hline $1 / 28$ & 0.00 & 0.00 & 0.00 & 0.00 & 0.00 & 0.00 & 0.00 & 0.00 & 0.00 & 0.00 & 0.05 & 28 \\
\hline $1 / 29$ & 0.00 & 0.00 & 0.00 & 0.00 & 0.00 & 0.00 & 0.00 & 0.00 & 0.00 & 0.00 & 0.00 & 29 \\
\hline $1 / 30$ & 0.00 & 0.00 & 0.00 & 0.00 & 0.00 & 0.00 & 0.00 & 0.00 & 0.00 & 0.00 & 0.00 & 30 \\
\hline $1 / 31$ & 0.00 & 0.00 & 0.00 & 0.00 & 0.00 & 0.00 & 0.00 & 0.00 & 0.00 & 0.00 & 0.00 & 31 \\
\hline $2 / 1$ & 0.00 & 0.00 & 0.00 & 0.00 & 0.00 & 0.00 & 0.00 & 0.00 & 0.00 & 0.00 & 0.00 & 32 \\
\hline $2 / 2$ & 0.00 & 0.00 & 0.00 & 0.00 & 0.00 & 0.00 & 0.00 & 0.00 & 0.00 & 0.00 & 0.00 & 33 \\
\hline $2 / 3$ & 0.00 & 0.00 & 0.00 & 0.00 & 0.00 & 0.00 & 0.00 & 0.00 & 0.00 & 0.00 & 0.00 & 34 \\
\hline
\end{tabular}




\begin{tabular}{|c|c|c|c|c|c|c|c|c|c|c|c|c|}
\hline $\begin{array}{l}\text { Date } \\
(2010)\end{array}$ & $\begin{array}{c}A Z \\
C: 05: 0031 \mathrm{U}\end{array}$ & $\begin{array}{c}A Z \\
C: 05: 0031 \mathrm{~L}\end{array}$ & $\begin{array}{c}A Z \\
C: 13: 0365 \mathrm{U}\end{array}$ & $\begin{array}{c}A Z \\
C: 13: 0365 \mathrm{~L}\end{array}$ & $\begin{array}{c}A Z \\
C: 13: 0006\end{array}$ & $\begin{array}{c}A Z \\
C: 13: 0336 \mathrm{U}\end{array}$ & $\begin{array}{c}A Z \\
C: 13: 0346 \mathrm{U}\end{array}$ & $\begin{array}{c}A Z \\
C: 13: 0346 \mathrm{~L}\end{array}$ & $\begin{array}{c}A Z \\
B: 11: 0281\end{array}$ & $\begin{array}{c}A Z \\
A: 15: 0033\end{array}$ & $\begin{array}{c}\text { AZ } \\
\text { G:03:0072 }\end{array}$ & $\begin{array}{l}\text { Year } \\
\text { day }\end{array}$ \\
\hline $2 / 4$ & 0.00 & 0.00 & 0.00 & 0.00 & 0.00 & 0.00 & 0.00 & 0.00 & 0.00 & 0.00 & U. & 35 \\
\hline $2 / 5$ & 0.00 & 0.00 & 0.00 & 0.00 & 0.00 & 0.00 & 0.00 & 0.00 & 0.08 & 1.50 & 0.99 & 36 \\
\hline $2 / 6$ & 4.60 & 4.70 & 4.32 & 4.39 & 4.24 & 3.30 & 3.18 & 3.05 & 13.61 & 25.55 & 16.48 & 37 \\
\hline $2 / 7$ & 0.41 & 0.38 & 0.46 & 0.51 & 0.86 & 0.38 & 0.23 & 0.15 & 2.39 & 10.44 & 8.61 & 38 \\
\hline $2 / 8$ & 0.25 & 0.38 & 0.18 & 0.23 & 0.25 & 0.13 & 0.00 & 0.03 & 0.15 & 0.13 & 0.00 & 39 \\
\hline $2 / 9$ & 4.06 & 4.50 & 7.04 & 7.62 & 5.08 & 3.99 & 2.46 & 2.08 & 1.02 & 1.83 & 0.91 & 40 \\
\hline $2 / 10$ & 0.41 & 0.28 & 0.00 & 0.00 & 0.00 & 0.00 & 0.00 & 0.00 & 0.00 & 0.00 & 0.00 & 41 \\
\hline $2 / 11$ & 0.00 & 0.00 & 0.00 & 0.00 & 0.00 & 0.00 & 0.00 & 0.00 & 0.00 & 0.00 & 0.00 & 42 \\
\hline $2 / 12$ & 0.00 & 0.00 & 0.00 & 0.00 & 0.00 & 0.00 & 0.00 & 0.00 & 0.00 & 0.00 & 0.00 & 43 \\
\hline $2 / 13$ & 0.00 & 0.00 & 0.00 & 0.00 & 0.00 & 0.00 & 0.00 & 0.00 & 0.00 & 0.00 & 0.00 & 44 \\
\hline $2 / 14$ & 0.00 & 0.00 & 0.00 & 0.00 & 0.00 & 0.00 & 0.00 & 0.00 & 0.00 & 0.00 & 0.00 & 45 \\
\hline $2 / 15$ & 0.00 & 0.00 & 0.00 & 0.00 & 0.00 & 0.00 & 0.00 & 0.00 & 0.00 & 0.00 & 0.00 & 46 \\
\hline $2 / 16$ & 0.00 & 0.00 & 0.03 & 0.00 & 0.00 & 0.00 & 0.00 & 0.00 & 0.00 & 0.00 & 0.00 & 47 \\
\hline $2 / 17$ & 0.00 & 0.00 & 0.00 & 0.00 & 0.00 & 0.00 & 0.00 & 0.00 & 0.00 & 0.00 & 0.00 & 48 \\
\hline $2 / 18$ & 0.00 & 0.00 & 0.03 & 0.05 & 0.00 & 0.00 & 0.00 & 0.00 & 0.00 & 0.00 & 0.00 & 49 \\
\hline $2 / 19$ & 0.00 & 0.03 & 0.00 & 0.00 & 0.00 & 0.00 & 0.00 & 0.00 & 0.00 & 0.00 & 0.00 & 50 \\
\hline $2 / 20$ & 10.41 & 11.43 & 1.47 & 1.63 & 0.84 & 1.96 & 1.40 & 1.14 & 6.68 & 0.36 & 1.27 & 51 \\
\hline $2 / 21$ & 26.21 & 27.86 & 14.02 & 13.67 & 11.53 & 7.26 & 7.57 & 6.22 & 8.43 & 0.99 & 3.58 & 52 \\
\hline $2 / 22$ & 8.03 & 8.69 & 9.73 & 10.39 & 12.78 & 11.91 & 12.29 & 11.89 & 5.64 & 2.29 & 3.94 & 53 \\
\hline $2 / 23$ & 0.00 & 0.00 & 0.00 & 0.00 & 0.00 & 0.00 & 0.00 & 0.00 & 0.00 & 0.00 & 0.00 & 54 \\
\hline $2 / 24$ & 0.23 & 0.28 & 0.30 & 0.33 & 0.58 & 0.53 & 0.23 & 0.23 & 1.60 & 0.00 & 0.00 & 55 \\
\hline $2 / 25$ & 0.00 & 0.00 & 0.00 & 0.00 & 0.00 & 0.00 & 0.00 & 0.00 & 0.00 & 0.00 & 0.00 & 56 \\
\hline $2 / 26$ & 0.00 & 0.00 & 0.00 & 0.00 & 0.00 & 0.00 & 0.00 & 0.00 & 0.00 & 0.00 & 0.00 & 57 \\
\hline $2 / 27$ & 0.13 & 0.15 & 2.16 & 1.88 & 0.66 & 0.08 & 0.05 & 0.08 & 2.97 & 1.50 & 0.25 & 58 \\
\hline $2 / 28$ & 0.10 & 0.18 & 0.10 & 0.08 & 0.13 & 0.18 & 0.30 & 0.28 & 0.00 & 0.00 & 0.00 & 59 \\
\hline $3 / 1$ & 0.00 & 0.00 & 0.00 & 0.00 & 0.00 & 0.00 & 0.00 & 0.00 & 0.00 & 0.00 & 0.00 & 60 \\
\hline $3 / 2$ & 0.00 & 0.00 & 0.00 & 0.00 & 0.00 & 0.00 & 0.00 & 0.00 & 0.00 & 0.00 & 0.00 & 61 \\
\hline $3 / 3$ & 0.00 & 0.00 & 0.00 & 0.00 & 0.00 & 0.00 & 0.00 & 0.00 & 0.00 & 0.00 & 0.00 & 62 \\
\hline $3 / 4$ & 0.03 & 0.03 & 0.46 & 0.36 & 0.20 & 0.08 & 0.69 & 0.51 & 0.51 & 0.25 & 0.00 & 63 \\
\hline $3 / 5$ & 0.00 & 0.00 & 0.00 & 0.00 & 0.00 & 0.00 & 0.00 & 0.00 & 0.00 & 0.00 & 0.00 & 64 \\
\hline $3 / 6$ & 0.53 & 0.71 & 0.08 & 0.05 & 0.05 & 0.05 & 0.05 & 0.03 & 6.05 & 4.24 & 4.75 & 65 \\
\hline $3 / 7$ & 9.70 & 10.44 & 12.04 & 12.19 & 10.62 & 10.16 & 9.25 & 8.79 & 15.65 & 3.43 & 1.85 & 66 \\
\hline $3 / 8$ & 0.00 & 0.00 & 0.00 & 0.00 & 0.00 & 0.00 & 0.00 & 0.00 & 0.00 & 0.03 & 0.28 & 67 \\
\hline $3 / 9$ & 1.63 & 2.06 & 1.07 & 1.50 & 3.07 & 3.99 & 3.30 & 2.67 & 14.12 & 5.69 & 3.15 & 68 \\
\hline $3 / 10$ & 0.00 & 0.03 & 0.00 & 0.00 & 0.00 & 0.08 & 0.00 & 0.00 & 0.38 & 0.05 & 0.05 & 69 \\
\hline $3 / 11$ & 0.00 & 0.00 & 0.00 & 0.00 & 0.00 & 0.00 & 0.00 & 0.00 & 0.00 & 0.00 & 0.00 & 70 \\
\hline
\end{tabular}




\begin{tabular}{|c|c|c|c|c|c|c|c|c|c|c|c|c|}
\hline $\begin{array}{l}\text { Date } \\
(2010)\end{array}$ & $\begin{array}{c}A Z \\
C: 05: 0031 \mathrm{U}\end{array}$ & $\begin{array}{c}A Z \\
C: 05: 0031 \mathrm{~L}\end{array}$ & $\begin{array}{c}A Z \\
C: 13: 0365 \mathrm{U}\end{array}$ & $\begin{array}{c}A Z \\
\text { C:13:0365 L }\end{array}$ & $\begin{array}{c}A Z \\
C: 13: 0006\end{array}$ & $\begin{array}{c}A Z \\
C: 13: 0336 \mathrm{U}\end{array}$ & $\begin{array}{c}A Z \\
C: 13: 0346 \mathrm{U}\end{array}$ & $\begin{array}{c}A Z \\
\text { C:13:0346 L }\end{array}$ & $\begin{array}{c}A Z \\
B: 11: 0281\end{array}$ & $\begin{array}{c}A Z \\
A: 15: 0033\end{array}$ & $\begin{array}{c}A Z \\
G: 03: 0072 \mathrm{U}\end{array}$ & $\begin{array}{l}\text { Yeal } \\
\text { day }\end{array}$ \\
\hline $3 / 12$ & 0.00 & 0.00 & 0.00 & 0.00 & 0.00 & 0.00 & 0.00 & 0.00 & 0.00 & 0.00 & 0.00 & 71 \\
\hline $3 / 13$ & 0.03 & 0.00 & 0.10 & 0.05 & 0.03 & 0.00 & 0.05 & 0.08 & 1.09 & 0.00 & 0.00 & 72 \\
\hline $3 / 14$ & 0.00 & 0.03 & 0.00 & 0.00 & 0.00 & 0.00 & 0.00 & 0.00 & 0.00 & 0.00 & 0.00 & 73 \\
\hline $3 / 15$ & 0.00 & 0.00 & 0.00 & 0.00 & 0.00 & 0.00 & 0.00 & 0.00 & 0.00 & 0.00 & 0.00 & 74 \\
\hline $3 / 16$ & 0.00 & 0.00 & 0.00 & 0.00 & 0.00 & 0.00 & 0.00 & 0.00 & 0.00 & 0.00 & 0.00 & 75 \\
\hline $3 / 17$ & 0.00 & 0.00 & 0.00 & 0.00 & 0.00 & 0.00 & 0.00 & 0.00 & 0.00 & 0.00 & 0.00 & 76 \\
\hline $3 / 18$ & 0.00 & 0.00 & 0.00 & 0.00 & 0.00 & 0.00 & 0.00 & 0.00 & 0.00 & 0.00 & 0.00 & 77 \\
\hline $3 / 19$ & 0.00 & 0.00 & 0.00 & 0.00 & 0.00 & 0.00 & 0.00 & 0.00 & 0.00 & 0.00 & 0.08 & 78 \\
\hline $3 / 20$ & 0.00 & 0.00 & 0.00 & 0.00 & 0.00 & 0.00 & 0.00 & 0.00 & 0.00 & 0.00 & 0.00 & 79 \\
\hline $3 / 21$ & 0.00 & 0.00 & 0.00 & 0.00 & 0.00 & 0.00 & 0.00 & 0.00 & 0.00 & 0.00 & 0.00 & 80 \\
\hline $3 / 22$ & 0.00 & 0.00 & 0.00 & 0.00 & 0.00 & 0.00 & 0.00 & 0.00 & 0.00 & 0.00 & 0.00 & 81 \\
\hline $3 / 23$ & 0.00 & 0.00 & 0.00 & 0.00 & 0.00 & 0.00 & 0.00 & 0.00 & 0.00 & 0.00 & 0.00 & 82 \\
\hline $3 / 24$ & 0.00 & 0.00 & 0.00 & 0.00 & 0.00 & 0.00 & 0.00 & 0.00 & 0.00 & 0.00 & 0.00 & 83 \\
\hline $3 / 25$ & 0.00 & 0.00 & 0.00 & 0.00 & 0.00 & 0.00 & 0.00 & 0.00 & 0.00 & 0.00 & 0.00 & 84 \\
\hline $3 / 26$ & 0.03 & 0.03 & 0.03 & 0.03 & 0.00 & 0.00 & 0.00 & 0.00 & 0.61 & 0.00 & 0.00 & 85 \\
\hline $3 / 27$ & 0.00 & 0.00 & 0.23 & 0.15 & 0.13 & 0.03 & 0.00 & 0.00 & 0.00 & 0.00 & 0.00 & 86 \\
\hline $3 / 28$ & 0.00 & 0.00 & 0.00 & 0.00 & 0.00 & 0.00 & 0.00 & 0.00 & 0.00 & 0.00 & 0.00 & 87 \\
\hline $3 / 29$ & 0.00 & 0.00 & 0.00 & 0.00 & 0.00 & 0.00 & 0.00 & 0.00 & 0.00 & 0.00 & 0.00 & 88 \\
\hline $3 / 30$ & 0.00 & 0.00 & 0.00 & 0.00 & 0.00 & 0.00 & 0.00 & 0.03 & 0.00 & 0.00 & 0.00 & 89 \\
\hline $3 / 31$ & 0.00 & 0.00 & 0.05 & 0.03 & 0.03 & 0.18 & 0.18 & 0.18 & 0.00 & 0.00 & 0.00 & 90 \\
\hline $4 / 1$ & 0.00 & 0.00 & 0.00 & 0.00 & 0.00 & 0.03 & 0.03 & 0.00 & 0.00 & 0.00 & 0.00 & 91 \\
\hline $4 / 2$ & 0.00 & 0.00 & 0.00 & 0.00 & 0.00 & 0.00 & 0.00 & 0.00 & 0.00 & 0.00 & 0.00 & 92 \\
\hline $4 / 3$ & 0.00 & 0.00 & 0.00 & 0.00 & 0.00 & 0.00 & 0.00 & 0.00 & 0.00 & 0.00 & 0.00 & 93 \\
\hline $4 / 4$ & 0.00 & 0.00 & 0.00 & 0.00 & 0.00 & 0.00 & 0.00 & 0.00 & 0.00 & 0.00 & 0.00 & 94 \\
\hline $4 / 5$ & 2.01 & 2.13 & 1.96 & 2.08 & 0.94 & 2.67 & 3.25 & 2.84 & 3.43 & 3.33 & 0.30 & 95 \\
\hline $4 / 6$ & 0.00 & 0.00 & 0.00 & 0.00 & 0.00 & 0.00 & 0.00 & 0.00 & 0.00 & 0.00 & 0.00 & 96 \\
\hline $4 / 7$ & 0.00 & 0.00 & 0.00 & 0.00 & 0.00 & 0.00 & 0.00 & 0.03 & 0.00 & 0.00 & 0.00 & 97 \\
\hline $4 / 8$ & 0.00 & 0.00 & 0.00 & 0.00 & 0.00 & 0.00 & 0.00 & 0.00 & 0.00 & 0.00 & 0.00 & 98 \\
\hline $4 / 9$ & 0.00 & 0.00 & 0.00 & 0.00 & 0.00 & 0.00 & 0.00 & 0.00 & 0.00 & 0.00 & 0.00 & 99 \\
\hline $4 / 10$ & 0.00 & 0.00 & 0.00 & 0.00 & 0.00 & 0.00 & 0.00 & 0.00 & 0.00 & 0.00 & 0.00 & 100 \\
\hline $4 / 11$ & 0.00 & 0.00 & 0.00 & 0.00 & 0.00 & 0.00 & 0.00 & 0.00 & 0.00 & 0.00 & 0.00 & 101 \\
\hline $4 / 12$ & 1.50 & 2.95 & 3.15 & 4.85 & 6.05 & 5.41 & 4.29 & 3.96 & 5.72 & 3.23 & 5.94 & 102 \\
\hline $4 / 13$ & 0.03 & 0.05 & 0.53 & 0.61 & 0.20 & 0.00 & 0.03 & 0.03 & 0.00 & 0.00 & 0.00 & 103 \\
\hline $4 / 14$ & 0.00 & 0.00 & 0.00 & 0.00 & 0.00 & 0.00 & 0.03 & 0.00 & 0.00 & 0.00 & 0.00 & 104 \\
\hline $4 / 15$ & 0.00 & 0.00 & 0.00 & 0.00 & 0.00 & 0.00 & 0.00 & 0.00 & 0.00 & 0.00 & 0.00 & 105 \\
\hline $4 / 16$ & 0.00 & 0.00 & 0.00 & 0.00 & 0.00 & 0.00 & 0.00 & 0.00 & 0.00 & 0.00 & 0.00 & 106 \\
\hline
\end{tabular}




\begin{tabular}{|c|c|c|c|c|c|c|c|c|c|c|c|c|}
\hline $\begin{array}{l}\text { Date } \\
(2010)\end{array}$ & $\begin{array}{c}A Z \\
C: 05: 0031 \mathrm{U}\end{array}$ & $\begin{array}{c}A Z \\
\text { C:05:0031 L }\end{array}$ & $\begin{array}{c}A Z \\
C: 13: 0365 \mathrm{U}\end{array}$ & $\begin{array}{c}A Z \\
C: 13: 0365 \mathrm{~L}\end{array}$ & $\begin{array}{c}A Z \\
C: 13: 0006\end{array}$ & $\begin{array}{c}A Z \\
C: 13: 0336 \mathrm{U}\end{array}$ & $\begin{array}{c}A Z \\
C: 13: 0346 \mathrm{U}\end{array}$ & $\begin{array}{c}A Z \\
C: 13: 0346 \mathrm{~L}\end{array}$ & $\begin{array}{c}A Z \\
B: 11: 0281\end{array}$ & $\begin{array}{c}A Z \\
A: 15: 0033\end{array}$ & $\begin{array}{c}A Z \\
G: 03: 0072 \mathrm{U}\end{array}$ & $\begin{array}{l}\text { Year } \\
\text { day }\end{array}$ \\
\hline $4 / 17$ & 0.03 & 0.00 & 0.00 & 0.00 & 0.00 & 0.00 & 0.00 & 0.00 & 0.00 & 0.00 & 0.00 & 107 \\
\hline $4 / 18$ & 0.00 & 0.00 & 0.00 & 0.00 & 0.00 & 0.00 & 0.00 & 0.00 & 0.00 & 0.00 & 0.00 & 108 \\
\hline $4 / 19$ & 0.00 & 0.00 & 0.00 & 0.00 & 0.00 & 0.00 & 0.00 & 0.00 & 0.00 & 0.00 & 0.00 & 109 \\
\hline $4 / 20$ & 0.00 & 0.00 & 0.00 & 0.00 & 0.00 & 0.00 & 0.00 & 0.00 & 0.00 & 0.03 & 0.00 & 110 \\
\hline $4 / 21$ & 0.00 & 0.00 & 0.00 & 0.03 & 0.05 & 0.30 & 3.00 & 2.59 & 2.64 & 0.43 & 0.13 & 111 \\
\hline $4 / 22$ & 0.00 & 0.00 & 0.00 & 0.00 & 0.00 & 0.03 & 0.23 & 0.18 & 0.05 & 6.73 & 0.58 & 112 \\
\hline $4 / 23$ & 0.00 & 0.00 & 0.08 & 0.08 & 0.10 & 0.00 & 0.05 & 0.00 & 0.36 & 0.00 & 0.00 & 113 \\
\hline $4 / 24$ & 0.00 & 0.00 & 0.00 & 0.00 & 0.00 & 0.00 & 0.00 & 0.00 & 0.00 & 0.00 & 0.00 & 114 \\
\hline $4 / 25$ & 0.00 & 0.00 & 0.00 & 0.00 & 0.00 & 0.00 & 0.00 & 0.00 & 0.00 & 0.00 & 0.00 & 115 \\
\hline $4 / 26$ & 0.00 & 0.00 & 0.00 & 0.00 & 0.00 & 0.00 & 0.00 & 0.00 & 0.00 & 0.00 & 0.00 & 116 \\
\hline $4 / 27$ & 0.00 & 0.00 & 0.00 & 0.00 & 0.00 & 0.00 & 0.00 & 0.00 & 0.00 & 0.00 & 0.00 & 117 \\
\hline $4 / 28$ & 0.00 & 0.00 & 0.10 & 0.00 & 0.03 & 0.00 & 0.03 & 0.05 & 0.00 & 0.00 & 0.00 & 118 \\
\hline $4 / 29$ & 0.13 & 0.10 & 3.33 & 4.19 & 1.42 & 6.71 & 0.79 & 0.61 & 4.57 & 0.20 & 1.65 & 119 \\
\hline $4 / 30$ & 0.00 & 0.00 & 0.00 & 0.00 & 0.00 & 0.00 & 0.00 & 0.00 & 0.00 & 0.00 & 0.00 & 120 \\
\hline $5 / 1$ & 0.00 & 0.00 & 0.00 & 0.00 & 0.00 & 0.00 & 0.00 & 0.00 & 0.00 & 0.00 & 0.00 & 121 \\
\hline $5 / 2$ & 0.13 & 0.18 & 0.46 & 0.53 & 0.51 & 0.56 & 0.71 & 0.61 & 0.23 & 0.00 & 0.53 & 122 \\
\hline $5 / 3$ & 0.00 & 0.00 & 0.00 & 0.00 & 0.00 & 0.00 & 0.00 & 0.00 & 0.00 & 0.00 & 0.00 & 123 \\
\hline $5 / 4$ & 0.00 & 0.00 & 0.00 & 0.00 & 0.00 & 0.00 & 0.00 & 0.00 & 0.00 & 0.00 & 0.00 & 124 \\
\hline $5 / 5$ & 0.00 & 0.00 & 0.00 & 0.00 & 0.00 & 0.00 & 0.00 & 0.00 & 0.00 & 0.00 & 0.00 & 125 \\
\hline $5 / 6$ & 0.00 & 0.00 & 0.00 & 0.00 & 0.00 & 0.00 & 0.00 & 0.00 & 0.00 & 0.00 & 0.00 & 126 \\
\hline $5 / 7$ & 0.00 & 0.00 & 0.00 & 0.00 & 0.00 & 0.00 & 0.00 & 0.00 & 0.00 & 0.00 & 0.00 & 127 \\
\hline $5 / 8$ & 0.00 & 0.00 & 0.00 & 0.00 & 0.00 & 0.00 & 0.00 & 0.00 & 0.00 & 0.00 & 0.00 & 128 \\
\hline $5 / 9$ & 0.00 & 0.00 & 0.05 & 0.00 & 0.03 & 0.03 & 0.00 & 0.00 & 0.03 & 0.00 & 0.03 & 129 \\
\hline $5 / 10$ & 0.03 & 0.00 & 0.10 & 0.18 & 0.61 & 0.25 & 0.08 & 0.05 & 0.00 & 0.00 & 0.00 & 130 \\
\hline $5 / 11$ & 0.36 & 0.46 & 0.20 & 0.25 & 0.53 & 0.03 & 0.05 & 0.03 & 4.11 & 0.25 & 0.03 & 131 \\
\hline $5 / 12$ & 0.05 & 0.10 & 0.08 & 0.08 & 0.03 & 0.00 & 0.00 & 0.00 & 3.00 & 0.76 & 0.00 & 132 \\
\hline $5 / 13$ & 0.00 & 0.00 & 0.00 & 0.00 & 0.00 & 0.00 & 0.00 & 0.00 & 0.00 & 0.00 & 0.00 & 133 \\
\hline $5 / 14$ & 0.03 & 0.00 & 0.05 & 0.08 & 0.05 & 0.28 & 0.00 & 0.03 & 0.03 & 0.00 & 0.00 & 134 \\
\hline $5 / 15$ & 0.03 & 0.00 & 0.00 & 0.00 & 0.00 & 0.00 & 0.00 & 0.00 & 0.00 & 0.00 & 0.00 & 135 \\
\hline $5 / 16$ & 0.00 & 0.00 & 0.00 & 0.00 & 0.00 & 0.00 & 0.00 & 0.00 & 0.00 & 0.00 & 0.00 & 136 \\
\hline $5 / 17$ & 0.00 & 0.00 & 0.00 & 0.00 & 0.00 & 0.00 & 0.00 & 0.00 & 0.00 & 0.00 & 0.00 & 137 \\
\hline $5 / 18$ & 0.00 & 0.00 & 0.03 & 0.00 & 0.03 & 0.13 & 0.10 & 0.08 & 0.00 & 0.00 & 0.00 & 138 \\
\hline $5 / 19$ & 0.00 & 0.00 & 0.00 & 0.00 & 0.00 & 0.00 & 0.00 & 0.00 & 0.00 & 0.00 & 0.00 & 139 \\
\hline $5 / 20$ & 0.00 & 0.00 & 0.00 & 0.00 & 0.00 & 0.00 & 0.00 & 0.03 & 0.00 & 0.00 & 0.00 & 140 \\
\hline $5 / 21$ & 0.00 & 0.00 & 0.05 & 0.00 & 0.00 & 0.00 & 0.00 & 0.00 & 0.00 & 0.00 & 0.00 & 141 \\
\hline $5 / 22$ & 0.00 & 0.00 & 0.08 & 0.00 & 0.00 & 0.03 & 0.00 & 0.00 & 0.00 & 0.00 & 0.00 & 142 \\
\hline
\end{tabular}




\begin{tabular}{|c|c|c|c|c|c|c|c|c|c|c|c|c|}
\hline $\begin{array}{l}\text { Date } \\
(2010)\end{array}$ & $\begin{array}{c}A Z \\
C: 05: 0031 \mathrm{U}\end{array}$ & $\begin{array}{c}A Z \\
C: 05: 0031 \mathrm{~L}\end{array}$ & $\begin{array}{c}A Z \\
C: 13: 0365 \mathrm{U}\end{array}$ & $\begin{array}{c}A Z \\
C: 13: 0365 \mathrm{~L}\end{array}$ & $\begin{array}{c}A Z \\
C: 13: 0006\end{array}$ & $\begin{array}{c}A Z \\
C: 13: 0336 \mathrm{U}\end{array}$ & $\begin{array}{c}A Z \\
C: 13: 0346 \mathrm{U}\end{array}$ & $\begin{array}{c}A Z \\
C: 13: 0346 \mathrm{~L}\end{array}$ & $\begin{array}{c}A Z \\
B: 11: 0281\end{array}$ & $\begin{array}{c}A Z \\
A: 15: 0033\end{array}$ & $\begin{array}{c}A Z \\
G: 03: 0072 \mathrm{U}\end{array}$ & $\begin{array}{l}\text { Yeal } \\
\text { day }\end{array}$ \\
\hline $5 / 23$ & 0.00 & 0.00 & 0.00 & 0.00 & 0.00 & 0.00 & 0.00 & 0.00 & 0.00 & 0.15 & 0.00 & 143 \\
\hline $5 / 24$ & 0.00 & 0.00 & 0.03 & 0.05 & 0.00 & 0.10 & 0.20 & 0.20 & 0.03 & 0.13 & 0.00 & 144 \\
\hline $5 / 25$ & 0.00 & 0.00 & 0.00 & 0.00 & 0.00 & 0.00 & 0.00 & 0.00 & 0.00 & 0.00 & 0.00 & 145 \\
\hline $5 / 26$ & 0.00 & 0.00 & 0.00 & 0.00 & 0.00 & 0.00 & 0.00 & 0.00 & 0.00 & 0.00 & 0.00 & 146 \\
\hline $5 / 27$ & 0.00 & 0.00 & 0.00 & 0.00 & 0.00 & 0.00 & 0.00 & 0.00 & 0.00 & 0.00 & 0.00 & 147 \\
\hline $5 / 28$ & 0.00 & 0.00 & 0.03 & 0.00 & 0.00 & 0.00 & 0.00 & 0.00 & 0.03 & 0.00 & 0.00 & 148 \\
\hline $5 / 29$ & 0.00 & 0.00 & 0.00 & 0.00 & 0.00 & 0.00 & 0.00 & 0.00 & 0.00 & 0.00 & 0.00 & 149 \\
\hline $5 / 30$ & 0.00 & 0.00 & 0.00 & 0.00 & 0.00 & 0.00 & 0.00 & 0.03 & 0.00 & 0.00 & 0.00 & 150 \\
\hline $5 / 31$ & 0.00 & 0.00 & 0.00 & 0.00 & 0.00 & 0.00 & 0.00 & 0.00 & 0.00 & 0.00 & 0.00 & 151 \\
\hline $6 / 1$ & 0.00 & 0.00 & 0.00 & 0.00 & 0.00 & 0.00 & 0.00 & 0.00 & 0.00 & 0.00 & 0.00 & 152 \\
\hline $6 / 2$ & 0.00 & 0.00 & 0.00 & 0.00 & 0.00 & 0.00 & 0.00 & 0.00 & 0.00 & 0.00 & 0.00 & 153 \\
\hline $6 / 3$ & 0.00 & 0.00 & 0.00 & 0.00 & 0.00 & 0.00 & 0.00 & 0.00 & 0.00 & 0.00 & 0.00 & 154 \\
\hline $6 / 4$ & 0.00 & 0.00 & 0.00 & 0.00 & 0.00 & 0.00 & 0.00 & 0.00 & 0.00 & 0.00 & 0.00 & 155 \\
\hline $6 / 5$ & 0.00 & 0.00 & 0.00 & 0.00 & 0.00 & 0.00 & 0.00 & 0.00 & 0.00 & 0.00 & 0.00 & 156 \\
\hline $6 / 6$ & 0.00 & 0.00 & 0.00 & 0.00 & 0.00 & 0.00 & 0.00 & 0.00 & 0.00 & 0.00 & 0.00 & 157 \\
\hline $6 / 7$ & 0.00 & 0.00 & 0.00 & 0.00 & 0.00 & 0.00 & 0.00 & 0.00 & 0.00 & 0.00 & 0.00 & 158 \\
\hline $6 / 8$ & 0.00 & 0.00 & 0.00 & 0.00 & 0.00 & 0.00 & 0.00 & 0.00 & 0.00 & 0.00 & 0.00 & 159 \\
\hline $6 / 9$ & 0.00 & 0.00 & 0.00 & 0.00 & 0.00 & 0.00 & 0.00 & 0.00 & 0.00 & 0.00 & 0.00 & 160 \\
\hline $6 / 10$ & 0.00 & 0.00 & 0.00 & 0.00 & 0.00 & 0.00 & 0.00 & 0.00 & 0.00 & 0.00 & 0.00 & 161 \\
\hline $6 / 11$ & 2.08 & 3.99 & 6.17 & 8.00 & 2.11 & 1.55 & 1.40 & 1.14 & 0.61 & 0.00 & 0.00 & 162 \\
\hline $6 / 12$ & 2.31 & 3.33 & 8.15 & 9.45 & 6.02 & 4.65 & 6.76 & 6.83 & 2.62 & 11.10 & 0.20 & 163 \\
\hline $6 / 13$ & 0.00 & 0.00 & 0.00 & 0.00 & 0.00 & 0.00 & 0.00 & 0.00 & 0.00 & 0.00 & 0.00 & 164 \\
\hline $6 / 14$ & 0.00 & 0.00 & 0.00 & 0.00 & 0.00 & 0.00 & 0.00 & 0.00 & 0.00 & 0.00 & 0.00 & 165 \\
\hline $6 / 15$ & 0.00 & 0.00 & 0.00 & 0.00 & 0.00 & 0.00 & 0.00 & 0.00 & 0.00 & 0.00 & 0.00 & 166 \\
\hline $6 / 16$ & 0.00 & 0.00 & 0.03 & 0.00 & 0.00 & 0.00 & 0.03 & 0.00 & 0.00 & 0.00 & 0.00 & 167 \\
\hline $6 / 17$ & 0.00 & 0.00 & 0.00 & 0.00 & 0.00 & 0.00 & 0.00 & 0.00 & 0.00 & 0.00 & 0.00 & 168 \\
\hline $6 / 18$ & 0.00 & 0.00 & 0.00 & 0.00 & 0.00 & 0.00 & 0.00 & 0.00 & 0.00 & 0.00 & 0.00 & 169 \\
\hline $6 / 19$ & 0.00 & 0.00 & 0.00 & 0.00 & 0.00 & 0.00 & 0.00 & 0.00 & 0.00 & 0.00 & 0.00 & 170 \\
\hline $6 / 20$ & 0.00 & 0.00 & 0.00 & 0.00 & 0.00 & 0.00 & 0.00 & 0.00 & 0.00 & 0.00 & 0.00 & 171 \\
\hline $6 / 21$ & 0.00 & 0.00 & 0.00 & 0.00 & 0.00 & 0.00 & 0.00 & 0.00 & 0.00 & 0.00 & 0.00 & 172 \\
\hline $6 / 22$ & 0.00 & 0.00 & 0.00 & 0.00 & 0.00 & 0.00 & 0.00 & 0.00 & 0.00 & 0.00 & 0.00 & 173 \\
\hline $6 / 23$ & 0.00 & 0.00 & 0.00 & 0.00 & 0.00 & 0.00 & 0.00 & 0.00 & 0.00 & 0.00 & 0.00 & 174 \\
\hline $6 / 24$ & 0.00 & 0.00 & 0.00 & 0.00 & 0.00 & 0.00 & 0.00 & 0.00 & 0.00 & 0.00 & 0.00 & 175 \\
\hline $6 / 25$ & 0.20 & 0.20 & 3.56 & 3.58 & 4.80 & 0.23 & 0.25 & 0.28 & 0.76 & 0.00 & 0.00 & 176 \\
\hline $6 / 26$ & 0.00 & 0.00 & 0.00 & 0.00 & 0.00 & 0.00 & 0.00 & 0.00 & 0.00 & 0.00 & 0.00 & 177 \\
\hline
\end{tabular}




\begin{tabular}{|c|c|c|c|c|c|c|c|c|c|c|c|c|}
\hline $\begin{array}{l}\text { Date } \\
(2010)\end{array}$ & $\begin{array}{c}A Z \\
C: 05: 0031 \mathrm{U}\end{array}$ & $\begin{array}{c}A Z \\
\text { C:05:0031 L }\end{array}$ & $\begin{array}{c}A Z \\
C: 13: 0365 \mathrm{U}\end{array}$ & $\begin{array}{c}A Z \\
C: 13: 0365 \mathrm{~L}\end{array}$ & $\begin{array}{c}A Z \\
C: 13: 0006\end{array}$ & $\begin{array}{c}A Z \\
C: 13: 0336 \mathrm{U}\end{array}$ & $\begin{array}{c}A Z \\
C: 13: 0346 \mathrm{U}\end{array}$ & $\begin{array}{c}A Z \\
\text { C:13:0346 L }\end{array}$ & $\begin{array}{c}A Z \\
B: 11: 0281\end{array}$ & $\begin{array}{c}A Z \\
A: 15: 0033\end{array}$ & $\begin{array}{c}A Z \\
G: 03: 0072 \mathrm{U}\end{array}$ & $\begin{array}{l}\text { Year } \\
\text { day }\end{array}$ \\
\hline $6 / 27$ & 0.00 & 0.00 & 0.03 & 0.00 & 0.00 & 0.00 & 0.00 & 0.00 & 0.00 & 0.00 & 0.00 & 178 \\
\hline $6 / 28$ & 0.00 & 0.00 & 0.00 & 0.00 & 0.00 & 0.00 & 0.00 & 0.00 & 0.00 & 0.00 & 0.00 & 179 \\
\hline $6 / 29$ & 0.03 & 0.03 & 0.00 & 0.00 & 0.13 & 0.20 & 0.05 & 0.03 & 0.00 & 0.00 & 0.00 & 180 \\
\hline $6 / 30$ & 0.03 & 0.03 & 0.10 & 0.10 & 0.20 & 0.28 & 0.33 & 0.41 & 0.00 & 0.00 & 0.00 & 181 \\
\hline $7 / 1$ & 0.00 & 0.00 & 0.00 & 0.00 & 0.00 & 0.00 & 0.00 & 0.00 & 0.00 & 0.00 & 0.00 & 182 \\
\hline $7 / 2$ & 0.00 & 0.00 & 0.00 & 0.05 & 0.00 & 0.00 & 0.00 & 0.00 & 0.00 & 0.00 & 0.00 & 183 \\
\hline $7 / 3$ & 0.00 & 0.00 & 0.03 & 0.00 & 0.00 & 0.00 & 0.00 & 0.00 & 0.00 & 0.00 & 0.00 & 184 \\
\hline $7 / 4$ & 0.00 & 0.00 & 0.00 & 0.00 & 0.00 & 0.00 & 0.00 & 0.00 & 0.00 & 0.00 & 0.00 & 185 \\
\hline $7 / 5$ & 0.00 & 0.00 & 0.00 & 0.00 & 0.00 & 0.00 & 0.00 & 0.00 & 0.00 & 0.00 & 0.00 & 186 \\
\hline $7 / 6$ & 0.00 & 0.00 & 0.00 & 0.03 & 0.00 & 0.00 & 0.00 & 0.00 & 0.00 & 0.00 & 0.00 & 187 \\
\hline $7 / 7$ & 0.00 & 0.00 & 0.00 & 0.00 & 0.00 & 0.05 & 0.08 & 0.08 & 0.00 & 0.00 & 0.00 & 188 \\
\hline $7 / 8$ & 0.00 & 0.00 & 0.00 & 0.00 & 0.00 & 0.00 & 0.00 & 0.00 & 0.00 & 0.03 & 0.00 & 189 \\
\hline $7 / 9$ & 0.00 & 0.03 & 0.81 & 1.30 & 0.94 & 0.30 & 2.06 & 2.41 & 0.36 & 0.00 & 0.00 & 190 \\
\hline $7 / 10$ & 0.51 & 0.76 & 0.84 & 0.76 & 0.79 & 0.00 & 0.00 & 0.00 & 0.03 & 0.00 & 0.00 & 191 \\
\hline $7 / 11$ & 1.07 & 1.91 & 1.55 & 1.75 & 0.97 & 0.03 & 1.60 & 1.85 & 0.00 & 0.00 & 0.00 & 192 \\
\hline $7 / 12$ & 0.00 & 0.00 & 0.00 & 0.00 & 0.00 & 0.00 & 0.00 & 0.00 & 3.07 & 0.00 & 0.00 & 193 \\
\hline $7 / 13$ & 0.00 & 0.03 & 0.00 & 0.00 & 0.00 & 0.00 & 0.00 & 0.00 & 0.00 & 0.00 & 0.00 & 194 \\
\hline $7 / 14$ & 0.00 & 0.00 & 0.00 & 0.00 & 0.00 & 0.00 & 0.00 & 0.00 & 0.00 & 0.00 & 0.00 & 195 \\
\hline $7 / 15$ & 0.00 & 0.00 & 0.00 & 0.00 & 0.00 & 0.00 & 0.00 & 0.00 & 0.00 & 0.00 & 0.00 & 196 \\
\hline $7 / 16$ & 0.00 & 0.00 & 0.00 & 0.00 & 0.00 & 0.00 & 0.00 & 0.00 & 2.90 & 16.81 & 0.00 & 197 \\
\hline $7 / 17$ & 0.03 & 0.03 & 2.64 & 3.07 & 1.55 & 0.00 & 0.00 & 0.00 & 0.00 & 0.00 & 0.00 & 198 \\
\hline 7/18 & 0.00 & 0.00 & 0.03 & 0.00 & 0.00 & 0.00 & 0.00 & 0.00 & 0.00 & 0.00 & 0.00 & 199 \\
\hline $7 / 19$ & 22.99 & 29.08 & 0.00 & 0.00 & 0.00 & 1.24 & 0.00 & 0.03 & 0.00 & 0.00 & 0.00 & 200 \\
\hline $7 / 20$ & 0.41 & 0.53 & 1.09 & 1.70 & 2.03 & 1.80 & 1.17 & 0.99 & 0.00 & 0.00 & 0.00 & 201 \\
\hline $7 / 21$ & 0.10 & 0.08 & 0.13 & 0.18 & 0.05 & 0.08 & 0.05 & 0.03 & 2.34 & 0.00 & 0.00 & 202 \\
\hline $7 / 22$ & 1.37 & 1.19 & 11.35 & 16.48 & 6.20 & 0.00 & 0.03 & 0.03 & 0.00 & 0.00 & 0.00 & 203 \\
\hline $7 / 23$ & 0.00 & 0.00 & 0.00 & 0.00 & 0.00 & 0.00 & 0.03 & 0.03 & 5.51 & 0.00 & 1.55 & 204 \\
\hline $7 / 24$ & 0.00 & 0.00 & 0.00 & 0.00 & 0.00 & 0.36 & 0.30 & 0.25 & 0.00 & 0.00 & 0.00 & 205 \\
\hline $7 / 25$ & 0.00 & 0.00 & 0.00 & 0.00 & 1.96 & 0.30 & 0.00 & 0.05 & 0.00 & 4.29 & 0.00 & 206 \\
\hline $7 / 26$ & 3.58 & 5.11 & 0.00 & 0.00 & 0.00 & 0.00 & 0.00 & 0.00 & 0.05 & 0.00 & 0.53 & 207 \\
\hline $7 / 27$ & 0.53 & 1.22 & 28.68 & 35.71 & 26.44 & 23.22 & 3.78 & 3.25 & 0.76 & 0.00 & 0.00 & 208 \\
\hline $7 / 28$ & 0.03 & 0.03 & 1.70 & 2.08 & 4.42 & 3.30 & 1.70 & 1.50 & 0.08 & 0.03 & 0.03 & 209 \\
\hline $7 / 29$ & 0.00 & 0.00 & 0.00 & 0.00 & 0.08 & 0.00 & 0.00 & 0.00 & 3.71 & 0.00 & 0.00 & 210 \\
\hline $7 / 30$ & 0.03 & 0.00 & 0.00 & 0.00 & 0.00 & 5.03 & 0.05 & 0.00 & 0.79 & 6.30 & 0.41 & 211 \\
\hline $7 / 31$ & 8.53 & 11.43 & 10.01 & 13.44 & 6.35 & 6.88 & 11.00 & 9.22 & 14.33 & 7.82 & 8.13 & 212 \\
\hline $8 / 1$ & 11.07 & 16.00 & 1.78 & 2.74 & 7.01 & 5.11 & 7.26 & 6.81 & 0.00 & 0.00 & 0.00 & 213 \\
\hline
\end{tabular}




\begin{tabular}{|c|c|c|c|c|c|c|c|c|c|c|c|c|}
\hline $\begin{array}{l}\text { Date } \\
(2010)\end{array}$ & $\begin{array}{c}A Z \\
\text { C:05:0031 U }\end{array}$ & $\begin{array}{c}A Z \\
\text { C:05:0031 L }\end{array}$ & $\begin{array}{c}A Z \\
C: 13: 0365 \mathrm{U}\end{array}$ & $\begin{array}{c}A Z \\
C: 13: 0365 \mathrm{~L}\end{array}$ & $\begin{array}{c}A Z \\
C: 13: 0006\end{array}$ & $\begin{array}{c}A Z \\
C: 13: 0336 \mathrm{U}\end{array}$ & $\begin{array}{c}A Z \\
C: 13: 0346 \mathrm{U}\end{array}$ & $\begin{array}{c}A Z \\
\text { C:13:0346 L }\end{array}$ & $\begin{array}{c}A Z \\
B: 11: 0281\end{array}$ & $\begin{array}{c}A Z \\
A: 15: 0033\end{array}$ & $\begin{array}{c}A Z \\
G: 03: 0072 \mathrm{U}\end{array}$ & $\begin{array}{l}\text { Year } \\
\text { day }\end{array}$ \\
\hline $8 / 2$ & 0.00 & 0.00 & 0.00 & 0.00 & 0.00 & 0.00 & 0.00 & 0.00 & 0.00 & 0.00 & 0.00 & 214 \\
\hline $8 / 3$ & 0.00 & 0.00 & 0.00 & 0.00 & 0.00 & 0.00 & 0.00 & 0.00 & 0.00 & 0.00 & 0.00 & 215 \\
\hline $8 / 4$ & 0.00 & 0.00 & 0.00 & 0.00 & 0.00 & 0.00 & 0.00 & 0.00 & 0.00 & 0.00 & 0.89 & 216 \\
\hline $8 / 5$ & 6.20 & 8.33 & 0.00 & 0.00 & 4.04 & 9.30 & 7.57 & 5.44 & 0.25 & 0.00 & 0.00 & 217 \\
\hline $8 / 6$ & 0.30 & 0.41 & 13.21 & 13.74 & 7.24 & 13.31 & 9.75 & 9.22 & 0.00 & 0.00 & 0.00 & 218 \\
\hline $8 / 7$ & 6.25 & 9.78 & 14.63 & 18.80 & 13.64 & 13.74 & 18.80 & 18.64 & 3.30 & 0.58 & 1.02 & 219 \\
\hline $8 / 8$ & 0.00 & 0.00 & 0.00 & 0.05 & 0.33 & 5.16 & 9.19 & 9.83 & 0.94 & 6.78 & 0.08 & 220 \\
\hline $8 / 9$ & 0.00 & 0.00 & 0.00 & 0.00 & 0.00 & 0.00 & 0.00 & 0.00 & 0.00 & 0.00 & 0.00 & 221 \\
\hline $8 / 10$ & 0.00 & 0.03 & 0.30 & 0.30 & 0.00 & 0.00 & 0.00 & 0.00 & 0.00 & 0.00 & 0.00 & 222 \\
\hline $8 / 11$ & 0.00 & 0.00 & 0.05 & 0.13 & 0.00 & 0.00 & 0.00 & 0.00 & 0.00 & 0.00 & 0.00 & 223 \\
\hline $8 / 12$ & 0.00 & 0.00 & 0.00 & 0.00 & 0.00 & 0.00 & 0.00 & 0.00 & 0.00 & 0.00 & 0.00 & 224 \\
\hline $8 / 13$ & 0.00 & 0.00 & 0.00 & 0.00 & 0.00 & 0.00 & 0.00 & 0.00 & 0.00 & 0.00 & 0.00 & 225 \\
\hline $8 / 14$ & 0.00 & 0.00 & 0.00 & 0.00 & 0.00 & 0.00 & 0.00 & 0.00 & 0.00 & 0.00 & 0.00 & 226 \\
\hline $8 / 15$ & 0.00 & 0.00 & 0.00 & 0.00 & 0.00 & 0.00 & 0.00 & 0.00 & 0.00 & 0.00 & 0.00 & 227 \\
\hline $8 / 16$ & 7.59 & 10.21 & 0.00 & 0.00 & 0.00 & 0.00 & 0.05 & 0.03 & 0.03 & 0.03 & 12.47 & 228 \\
\hline $8 / 17$ & 0.05 & 0.08 & 0.23 & 0.23 & 0.00 & 0.00 & 0.00 & 0.00 & 0.00 & 0.00 & 0.00 & 229 \\
\hline 8/18 & 0.33 & 0.41 & 2.87 & 3.33 & 2.44 & 4.01 & 0.66 & 0.48 & 0.03 & 0.00 & 0.00 & 230 \\
\hline 8/19 & 7.80 & 10.92 & 0.03 & 0.05 & 0.00 & 0.00 & 0.00 & 0.03 & 0.00 & 0.00 & 0.00 & 231 \\
\hline $8 / 20$ & 0.00 & 0.00 & 0.00 & 0.00 & 0.00 & 0.00 & 0.25 & 0.30 & 10.16 & 0.00 & 0.00 & 232 \\
\hline $8 / 21$ & 0.00 & 0.00 & 0.00 & 0.00 & 0.00 & 0.00 & 0.00 & 0.00 & 4.93 & 0.05 & 0.00 & 233 \\
\hline $8 / 22$ & 0.00 & 0.00 & 0.08 & 0.13 & 0.41 & 1.02 & 3.28 & 3.10 & 0.00 & 0.00 & 0.71 & 234 \\
\hline $8 / 23$ & 0.00 & 0.00 & 0.03 & 0.05 & 0.28 & 0.00 & 0.00 & 0.00 & 0.00 & 0.00 & 0.00 & 235 \\
\hline $8 / 24$ & 0.00 & 0.00 & 0.00 & 0.00 & 0.00 & 0.00 & 0.00 & 0.00 & 0.00 & 0.00 & 0.00 & 236 \\
\hline $8 / 25$ & 0.00 & 0.00 & 0.00 & 0.00 & 0.00 & 0.00 & 0.00 & 0.00 & 0.00 & 0.03 & 0.00 & 237 \\
\hline $8 / 26$ & 0.00 & 0.00 & 0.00 & 0.00 & 0.00 & 0.00 & 0.00 & 0.00 & 0.00 & 0.00 & 0.00 & 238 \\
\hline $8 / 27$ & 0.36 & 0.69 & 2.64 & 2.74 & 2.29 & 3.73 & 5.77 & 4.83 & 0.08 & 4.80 & 13.03 & 239 \\
\hline $8 / 28$ & 0.00 & 0.00 & 0.00 & 0.03 & 0.00 & 0.00 & 0.00 & 0.00 & 0.00 & 0.13 & 0.71 & 240 \\
\hline $8 / 29$ & 0.00 & 0.00 & 0.05 & 0.05 & 0.00 & 0.03 & 0.08 & 0.03 & 0.00 & 0.00 & 0.00 & 241 \\
\hline $8 / 30$ & 0.00 & 0.00 & 0.00 & 0.00 & 0.00 & 0.00 & 0.00 & 0.38 & 0.00 & 0.00 & 0.00 & 242 \\
\hline $8 / 31$ & 0.00 & 0.00 & 0.00 & 0.00 & 0.00 & 0.00 & 0.00 & 0.00 & 0.00 & 0.00 & 0.00 & 243 \\
\hline $9 / 1$ & 0.00 & 0.00 & 0.00 & 0.00 & 0.00 & 0.00 & 0.00 & 0.00 & 0.00 & 0.00 & 0.00 & 244 \\
\hline $9 / 2$ & 0.00 & 0.00 & 0.00 & 0.00 & 0.00 & 0.00 & 0.00 & 0.00 & 0.00 & N/A & 0.00 & 245 \\
\hline $9 / 3$ & 0.00 & 0.00 & 0.00 & 0.00 & 0.00 & 0.00 & 0.00 & 0.00 & 0.00 & N/A & 0.00 & 246 \\
\hline $9 / 4$ & 0.00 & 0.00 & 0.00 & 0.00 & 0.00 & 0.00 & 0.00 & 0.00 & 0.00 & N/A & 0.00 & 247 \\
\hline $9 / 5$ & 0.00 & 0.00 & 0.00 & 0.00 & 0.00 & 0.00 & 0.00 & 0.00 & 0.00 & N/A & 0.00 & 248 \\
\hline $9 / 6$ & 0.00 & 0.00 & 0.00 & 0.00 & 0.00 & 0.00 & 0.00 & 0.00 & 0.00 & N/A & 0.00 & 249 \\
\hline
\end{tabular}




\begin{tabular}{|c|c|c|c|c|c|c|c|c|c|c|c|c|}
\hline $\begin{array}{l}\text { Date } \\
(2010)\end{array}$ & $\begin{array}{c}A Z \\
C: 05: 0031 \mathrm{U}\end{array}$ & $\begin{array}{c}A Z \\
C: 05: 0031 L\end{array}$ & $\begin{array}{c}A Z \\
C: 13: 0365 \mathrm{U}\end{array}$ & $\begin{array}{c}A Z \\
C: 13: 0365 \mathrm{~L}\end{array}$ & $\begin{array}{c}A Z \\
C: 13: 0006\end{array}$ & $\begin{array}{c}A Z \\
C: 13: 0336 \mathrm{U}\end{array}$ & $\begin{array}{c}A Z \\
C: 13: 0346 \mathrm{U}\end{array}$ & $\begin{array}{c}A Z \\
C: 13: 0346 \mathrm{~L}\end{array}$ & $\begin{array}{c}A Z \\
B: 11: 0281\end{array}$ & $\begin{array}{c}A Z \\
A: 15: 0033\end{array}$ & $\begin{array}{c}A Z \\
G: 03: 0072 \mathrm{U}\end{array}$ & $\begin{array}{l}\text { Year } \\
\text { day }\end{array}$ \\
\hline $9 / 7$ & 1.09 & 1.52 & 1.32 & 1.68 & 1.47 & 5.41 & 3.00 & 2.82 & 1.09 & N/A & 0.79 & 250 \\
\hline $9 / 8$ & 0.00 & 0.00 & 0.03 & 0.00 & 0.00 & 0.00 & 0.00 & 0.00 & 0.00 & N/A & 0.00 & 251 \\
\hline $9 / 9$ & 0.00 & 0.00 & 0.00 & 0.00 & 0.00 & 0.00 & 0.00 & 0.00 & 0.00 & N/A & 0.00 & 252 \\
\hline $9 / 10$ & 0.00 & 0.00 & 0.00 & 0.00 & 0.00 & 0.00 & 0.00 & 0.00 & 0.00 & N/A & 0.00 & 253 \\
\hline $9 / 11$ & 0.00 & 0.00 & 0.00 & 0.00 & 0.00 & 0.00 & 0.00 & 0.00 & 0.00 & N/A & 0.00 & 254 \\
\hline $9 / 12$ & 0.00 & 0.03 & 0.00 & 0.00 & 0.00 & 0.00 & 0.00 & 0.00 & 0.00 & N/A & 0.00 & 255 \\
\hline $9 / 13$ & 0.00 & 0.00 & 0.00 & 0.00 & 0.00 & 0.00 & 0.00 & 0.00 & 0.00 & N/A & 0.00 & 256 \\
\hline $9 / 14$ & 0.00 & 0.00 & 0.00 & 0.00 & 0.00 & 0.00 & 0.00 & 0.00 & 0.00 & N/A & 0.00 & 257 \\
\hline $9 / 15$ & 0.00 & 0.00 & 0.00 & 0.00 & 0.00 & 0.00 & 0.00 & 0.00 & 0.00 & N/A & 0.00 & 258 \\
\hline $9 / 16$ & 0.03 & 0.00 & 0.00 & 0.00 & 0.00 & 0.00 & 0.00 & 0.00 & 0.00 & N/A & 0.00 & 259 \\
\hline $9 / 17$ & 0.00 & 0.00 & 0.00 & 0.00 & 0.00 & 0.00 & 0.00 & 0.00 & 0.00 & N/A & 0.00 & 260 \\
\hline 9/18 & 0.00 & 0.00 & 0.00 & 0.00 & 0.00 & 0.00 & 0.00 & 0.00 & 0.00 & N/A & 0.00 & 261 \\
\hline $9 / 19$ & 0.00 & 0.00 & 0.00 & 0.00 & 0.00 & 0.00 & 0.00 & 0.00 & 0.00 & N/A & 0.00 & 262 \\
\hline $9 / 20$ & 0.00 & 0.00 & 0.00 & 0.00 & 0.00 & 0.00 & 0.00 & 0.00 & 0.00 & N/A & 0.00 & 263 \\
\hline $9 / 21$ & 0.00 & 0.00 & 0.00 & 0.00 & 0.00 & 0.00 & 0.00 & 0.00 & 0.00 & N/A & 0.00 & 264 \\
\hline $9 / 22$ & 0.08 & 0.18 & 3.02 & 3.45 & 2.54 & 0.25 & 0.30 & 0.30 & 0.00 & N/A & 0.00 & 265 \\
\hline $9 / 23$ & 0.00 & 0.00 & 0.00 & 0.00 & 0.00 & 0.00 & 0.00 & 0.00 & 0.00 & N/A & 0.00 & 266 \\
\hline $9 / 24$ & 0.00 & 0.00 & 0.00 & 0.00 & 0.00 & 0.00 & 0.00 & 0.00 & 0.00 & N/A & 0.00 & 267 \\
\hline $9 / 25$ & 0.00 & 0.00 & 0.00 & 0.00 & 0.00 & 0.00 & 0.00 & 0.00 & 0.00 & N/A & 0.00 & 268 \\
\hline $9 / 26$ & 0.00 & 0.00 & 0.00 & 0.00 & 0.00 & 0.00 & 0.00 & 0.00 & 0.00 & N/A & 0.00 & 269 \\
\hline $9 / 27$ & 0.00 & 0.00 & 0.00 & 0.00 & 0.00 & 0.00 & 0.00 & 0.00 & 0.00 & N/A & 0.00 & 270 \\
\hline $9 / 28$ & 0.00 & 0.00 & 0.00 & 0.00 & 0.00 & 0.00 & 0.00 & 0.00 & 0.00 & N/A & 0.00 & 271 \\
\hline $9 / 29$ & 0.03 & 0.00 & 0.00 & 0.00 & 0.00 & 0.00 & 0.00 & 0.03 & 0.00 & 0.0 & 0.00 & 272 \\
\hline $9 / 30$ & 0.03 & 0.00 & 0.00 & 0.00 & 0.00 & 0.00 & 0.00 & 0.00 & 0.00 & 0.0 & 0.00 & 273 \\
\hline $10 / 1$ & 0.00 & 0.00 & 0.03 & 0.00 & 0.00 & 0.23 & 1.04 & 1.04 & 0.99 & 0.33 & 0.00 & 274 \\
\hline $10 / 2$ & 0.00 & 0.00 & 0.00 & 0.00 & 0.00 & 0.05 & 0.28 & 0.20 & 0.05 & 0.00 & 0.00 & 275 \\
\hline $10 / 3$ & 6.20 & 9.63 & 1.14 & 1.24 & 0.00 & 0.05 & 0.08 & 0.03 & 11.05 & 0.00 & 0.00 & 276 \\
\hline $10 / 4$ & 20.73 & 33.35 & 17.04 & 22.15 & 30.48 & 19.91 & 19.71 & 16.05 & 16.69 & 29.69 & 33.58 & 277 \\
\hline $10 / 5$ & 30.99 & 48.06 & 38.28 & 45.69 & 43.18 & 27.05 & 27.36 & 23.09 & 42.62 & 19.13 & 11.35 & 278 \\
\hline $10 / 6$ & 18.29 & 28.83 & 36.04 & 43.92 & 43.18 & 46.58 & 46.33 & 5.61 & 13.41 & 0.03 & 0.00 & 279 \\
\hline $10 / 7$ & 0.00 & 0.00 & 0.00 & 0.00 & 0.00 & 0.00 & 0.00 & 0.00 & 0.00 & 0.00 & 0.00 & 280 \\
\hline $10 / 8$ & 0.00 & 0.00 & 0.00 & 0.00 & 0.00 & 0.00 & 0.00 & 0.00 & 0.00 & 0.00 & 0.00 & 281 \\
\hline $10 / 9$ & 0.00 & 0.00 & 0.00 & 0.00 & 0.00 & 0.00 & 0.00 & 0.00 & 0.00 & 0.00 & 0.00 & 282 \\
\hline $10 / 10$ & 0.00 & 0.00 & 0.00 & 0.00 & 0.00 & 0.00 & 0.00 & 0.00 & 0.00 & 0.00 & 0.00 & 283 \\
\hline $10 / 11$ & 0.00 & 0.00 & 0.00 & 0.00 & 0.00 & 0.00 & 0.00 & 0.00 & 0.00 & 0.00 & 0.00 & 284 \\
\hline $10 / 12$ & 0.00 & 0.00 & 0.00 & 0.00 & 0.00 & 0.00 & 0.00 & 0.00 & 0.00 & 0.00 & 0.00 & 285 \\
\hline
\end{tabular}




\begin{tabular}{|c|c|c|c|c|c|c|c|c|c|c|c|c|}
\hline $\begin{array}{l}\text { Date } \\
(2010)\end{array}$ & $\begin{array}{c}A Z \\
\text { C:05:0031 U }\end{array}$ & $\begin{array}{c}A Z \\
\text { C:05:0031 L }\end{array}$ & $\begin{array}{c}A Z \\
C: 13: 0365 \mathrm{U}\end{array}$ & $\begin{array}{c}A Z \\
\text { C:13:0365 L }\end{array}$ & $\begin{array}{c}A Z \\
C: 13: 0006\end{array}$ & $\begin{array}{c}A Z \\
C: 13: 0336 \mathrm{U}\end{array}$ & $\begin{array}{c}A Z \\
C: 13: 0346 \mathrm{U}\end{array}$ & $\begin{array}{c}A Z \\
\text { C:13:0346 L }\end{array}$ & $\begin{array}{c}A Z \\
B: 11: 0281\end{array}$ & $\begin{array}{c}A Z \\
A: 15: 0033\end{array}$ & $\begin{array}{c}A Z \\
G: 03: 0072 \mathrm{U}\end{array}$ & $\begin{array}{l}\text { Year } \\
\text { day }\end{array}$ \\
\hline $10 / 13$ & 0.00 & 0.00 & 0.00 & 0.00 & 0.00 & 0.00 & 0.00 & 0.00 & 0.00 & 0.00 & 0.00 & 286 \\
\hline $10 / 14$ & 0.00 & 0.00 & 0.00 & 0.00 & 0.00 & 0.00 & 0.00 & 0.00 & 0.00 & 0.00 & 0.00 & 287 \\
\hline $10 / 15$ & 0.00 & 0.00 & 0.00 & 0.00 & 0.00 & 0.00 & 0.00 & 0.00 & 0.00 & 0.00 & 0.00 & 288 \\
\hline $10 / 16$ & 0.00 & 0.00 & 0.00 & 0.00 & 0.00 & 0.00 & 0.00 & 0.00 & 0.00 & 0.00 & 0.00 & 289 \\
\hline $10 / 17$ & 0.58 & 0.74 & 0.03 & 0.03 & 0.00 & 0.51 & 0.99 & 0.89 & 7.75 & 16.28 & 32.36 & 290 \\
\hline $10 / 18$ & 2.01 & 3.10 & 4.55 & 5.54 & 2.54 & 3.89 & 1.83 & 0.30 & 8.20 & 4.09 & 4.62 & 291 \\
\hline $10 / 19$ & 0.00 & 0.00 & 0.00 & 0.00 & 0.00 & 0.00 & 0.00 & 0.00 & 0.00 & 0.00 & 0.03 & 292 \\
\hline $10 / 20$ & 1.27 & 1.40 & 4.44 & 5.11 & 5.08 & 3.99 & 7.44 & 7.54 & 15.37 & 2.82 & 7.29 & 293 \\
\hline $10 / 21$ & 4.57 & 7.01 & 0.36 & 0.41 & 2.54 & 2.79 & 7.77 & 1.27 & 13.56 & 0.00 & 0.00 & 294 \\
\hline $10 / 22$ & 0.08 & 0.08 & 0.00 & 0.00 & 0.00 & 0.00 & 0.00 & 0.00 & 0.00 & 1.27 & 0.48 & 295 \\
\hline $10 / 23$ & 0.00 & 0.00 & 0.00 & 0.00 & 0.00 & 0.00 & 0.00 & 0.00 & 0.08 & 0.46 & 0.00 & 296 \\
\hline $10 / 24$ & 0.00 & 0.00 & 0.00 & 0.00 & 0.00 & 0.00 & 0.00 & 0.00 & 0.00 & 0.00 & 0.00 & 297 \\
\hline $10 / 25$ & 0.69 & 0.94 & 0.15 & 0.15 & 0.00 & 0.30 & 0.15 & 0.05 & 1.52 & 0.20 & 0.18 & 298 \\
\hline $10 / 26$ & 0.00 & 0.00 & 0.00 & 0.00 & 0.00 & 0.00 & 0.03 & 0.00 & 0.00 & 0.00 & 0.00 & 299 \\
\hline $10 / 27$ & 0.00 & 0.00 & 0.00 & 0.00 & 0.00 & 0.00 & 0.00 & 0.00 & 0.00 & 0.00 & 0.00 & 300 \\
\hline $10 / 28$ & 0.03 & 0.00 & 0.00 & 0.00 & 0.00 & 0.00 & 0.03 & 0.00 & 0.00 & 0.00 & 0.00 & 301 \\
\hline $10 / 29$ & 0.00 & 0.00 & 0.00 & 0.00 & 0.00 & 0.00 & 0.00 & 0.00 & 0.00 & 0.00 & 0.00 & 302 \\
\hline $10 / 30$ & 0.00 & 0.00 & 0.00 & 0.00 & 0.00 & 0.00 & 0.00 & 0.03 & 0.00 & 0.00 & 0.00 & 303 \\
\hline $10 / 31$ & 0.00 & 0.00 & 0.00 & 0.00 & 0.00 & 0.00 & 0.00 & 0.00 & 0.00 & 0.00 & 0.00 & 304 \\
\hline $11 / 1$ & 0.00 & 0.00 & 0.00 & 0.00 & 0.00 & 0.00 & 0.00 & 0.00 & 0.00 & 0.00 & 0.00 & 305 \\
\hline $11 / 2$ & 0.00 & 0.00 & 0.00 & 0.00 & 0.00 & 0.00 & 0.00 & 0.00 & 0.03 & 0.00 & 0.00 & 306 \\
\hline $11 / 3$ & 0.00 & 0.00 & 0.00 & 0.00 & 0.00 & 0.00 & 0.00 & 0.00 & 0.00 & 0.00 & 0.00 & 307 \\
\hline $11 / 4$ & 0.00 & 0.00 & 0.00 & 0.00 & 0.00 & 0.00 & 0.00 & 0.00 & 0.00 & 0.00 & 0.00 & 308 \\
\hline $11 / 5$ & 0.00 & 0.00 & 0.00 & 0.00 & 0.00 & 0.00 & 0.00 & 0.00 & 0.00 & 0.00 & 0.00 & 309 \\
\hline $11 / 6$ & 0.00 & 0.00 & 0.00 & 0.00 & 0.00 & 0.00 & 0.00 & 0.00 & 0.00 & 0.00 & 0.00 & 310 \\
\hline $11 / 7$ & 0.00 & 0.00 & 0.00 & 0.00 & 0.00 & 0.00 & 0.00 & 0.13 & 0.00 & 0.03 & 0.00 & 311 \\
\hline $11 / 8$ & 0.58 & 0.94 & 0.69 & 0.81 & 0.00 & 0.05 & 0.56 & 0.66 & 1.19 & 3.63 & 0.00 & 312 \\
\hline $11 / 9$ & 0.00 & 0.00 & 0.00 & 0.00 & 0.00 & 0.00 & 0.00 & 0.00 & 0.00 & 0.00 & 0.00 & 313 \\
\hline $11 / 10$ & 0.00 & 0.00 & 0.00 & 0.00 & 0.00 & 0.00 & 0.00 & 0.00 & 0.05 & 0.00 & 0.00 & 314 \\
\hline $11 / 11$ & 0.00 & 0.00 & 0.00 & 0.00 & 0.00 & 0.00 & 0.00 & 0.00 & 0.00 & 0.00 & 0.00 & 315 \\
\hline $11 / 12$ & 0.00 & 0.00 & 0.00 & 0.00 & 0.00 & 0.00 & 0.00 & 0.00 & 0.00 & 0.00 & 0.00 & 316 \\
\hline $11 / 13$ & 0.00 & 0.00 & 0.00 & 0.00 & 0.00 & 0.00 & 0.00 & 0.00 & 0.00 & 0.00 & 0.00 & 317 \\
\hline $11 / 14$ & 0.00 & 0.00 & 0.00 & 0.00 & 0.00 & 0.00 & 0.00 & 0.00 & 0.00 & 0.00 & 0.00 & 318 \\
\hline $11 / 15$ & 0.00 & 0.00 & 0.00 & 0.00 & 0.00 & 0.00 & 0.00 & 0.00 & 0.00 & 0.00 & 0.00 & 319 \\
\hline $11 / 16$ & 0.00 & 0.00 & 0.00 & 0.00 & 0.00 & 0.00 & 0.00 & 0.00 & 0.00 & 0.00 & 0.00 & 320 \\
\hline $11 / 17$ & 0.00 & 0.00 & 0.00 & 0.00 & 0.00 & 0.00 & 0.00 & 0.00 & 0.00 & 0.00 & 0.00 & 321 \\
\hline
\end{tabular}




\begin{tabular}{|c|c|c|c|c|c|c|c|c|c|c|c|c|}
\hline $\begin{array}{l}\text { Date } \\
(2010)\end{array}$ & $\begin{array}{c}A Z \\
C: 05: 0031 \mathrm{U}\end{array}$ & $\begin{array}{c}A Z \\
C: 05: 0031 L\end{array}$ & $\begin{array}{c}A Z \\
C: 13: 0365 \mathrm{U}\end{array}$ & $\begin{array}{c}A Z \\
C: 13: 0365 \mathrm{~L}\end{array}$ & $\begin{array}{c}A Z \\
C: 13: 0006\end{array}$ & $\begin{array}{c}A Z \\
C: 13: 0336 \mathrm{U}\end{array}$ & $\begin{array}{c}A Z \\
C: 13: 0346 \mathrm{U}\end{array}$ & $\begin{array}{c}A Z \\
C: 13: 0346 \mathrm{~L}\end{array}$ & $\begin{array}{c}A Z \\
B: 11: 0281\end{array}$ & $\begin{array}{c}A Z \\
A: 15: 0033\end{array}$ & $\begin{array}{c}A Z \\
G: 03: 0072 \mathrm{U}\end{array}$ & $\begin{array}{l}\text { Year } \\
\text { day }\end{array}$ \\
\hline $11 / 18$ & 0.00 & 0.00 & 0.00 & 0.00 & 0.00 & 0.00 & 0.03 & 0.00 & 0.00 & 0.00 & 0.00 & 322 \\
\hline $11 / 19$ & 0.00 & 0.00 & 0.00 & 0.00 & 0.00 & 0.00 & 0.00 & 0.00 & 0.00 & 0.00 & 0.00 & 323 \\
\hline $11 / 20$ & 0.05 & 0.08 & 0.66 & 0.99 & 0.00 & 0.08 & 0.10 & 0.05 & 0.13 & 8.10 & 4.42 & 324 \\
\hline $11 / 21$ & 1.27 & 1.47 & 3.07 & 4.34 & 0.00 & 2.13 & 4.22 & 4.22 & 9.17 & 6.65 & 2.44 & 325 \\
\hline $11 / 22$ & 0.00 & 0.00 & 0.00 & 0.00 & 0.00 & 0.00 & 0.00 & 0.03 & 0.00 & 0.00 & 0.00 & 326 \\
\hline $11 / 23$ & 0.00 & 0.00 & 0.00 & 0.00 & 0.00 & 0.00 & 0.00 & 0.00 & 0.00 & 0.00 & 0.00 & 327 \\
\hline $11 / 24$ & 0.00 & 0.00 & 0.23 & 0.20 & 0.00 & 0.20 & 0.23 & 0.03 & 2.67 & 0.53 & 0.25 & 328 \\
\hline $11 / 25$ & 0.00 & 0.00 & 0.00 & 0.00 & 0.00 & 0.00 & 0.00 & 0.00 & 0.00 & 0.00 & 0.00 & 329 \\
\hline $11 / 26$ & 0.00 & 0.00 & 0.00 & 0.00 & 0.00 & 0.00 & 0.00 & 0.00 & 0.00 & 0.00 & 0.00 & 330 \\
\hline $11 / 27$ & 0.00 & 0.00 & 0.00 & 0.00 & 0.00 & 0.00 & 0.00 & 0.00 & 0.00 & 0.00 & 0.00 & 331 \\
\hline $11 / 28$ & 0.10 & 0.18 & 0.00 & 0.00 & 0.00 & 0.25 & 0.25 & 0.20 & 0.74 & 0.05 & 0.03 & 332 \\
\hline $11 / 29$ & 0.00 & 0.00 & 0.00 & 0.00 & 0.00 & 0.00 & 0.00 & 0.00 & 0.00 & 0.00 & 0.00 & 333 \\
\hline $11 / 30$ & 0.00 & 0.00 & 0.00 & 0.00 & 0.00 & 0.00 & 0.00 & 0.00 & 0.00 & 0.00 & 0.00 & 334 \\
\hline $12 / 1$ & 0.00 & 0.00 & 0.00 & 0.00 & 0.00 & 0.00 & 0.00 & 0.10 & 0.00 & 0.00 & 0.00 & 335 \\
\hline $12 / 2$ & 0.00 & 0.00 & 0.00 & 0.00 & 0.00 & 0.00 & 0.00 & 0.00 & 0.00 & 0.00 & 0.00 & 336 \\
\hline $12 / 3$ & 0.00 & 0.00 & 0.00 & 0.00 & 0.00 & 0.00 & 0.00 & 0.03 & 0.00 & 0.00 & 0.00 & 337 \\
\hline $12 / 4$ & 0.00 & 0.00 & 0.00 & 0.00 & 0.00 & 0.00 & 0.00 & 0.00 & 0.00 & 0.00 & 0.00 & 338 \\
\hline $12 / 5$ & 0.00 & 0.00 & 0.00 & 0.00 & 0.00 & 0.00 & 0.00 & 0.00 & 0.00 & 0.00 & 0.00 & 339 \\
\hline $12 / 6$ & 0.05 & 0.08 & 0.13 & 0.10 & 0.00 & 0.33 & 0.51 & 0.61 & 0.08 & 0.05 & 0.08 & 340 \\
\hline $12 / 7$ & 0.00 & 0.00 & 0.00 & 0.00 & 0.00 & 0.00 & 0.00 & 0.00 & 0.00 & 0.00 & 0.00 & 341 \\
\hline $12 / 8$ & 0.00 & 0.00 & 0.00 & 0.00 & 0.00 & 0.00 & 0.00 & 0.00 & 0.00 & 0.00 & 0.00 & 342 \\
\hline $12 / 9$ & 0.00 & 0.00 & 0.00 & 0.00 & 0.00 & 0.00 & 0.00 & 0.00 & 0.00 & 0.00 & 0.00 & 343 \\
\hline $12 / 10$ & 0.00 & 0.00 & 0.00 & 0.00 & 0.00 & 0.00 & 0.00 & 0.00 & 0.00 & 0.00 & 0.00 & 344 \\
\hline $12 / 11$ & 0.00 & 0.00 & 0.00 & 0.00 & 0.00 & 0.00 & 0.00 & 0.00 & 0.00 & 0.00 & 0.00 & 345 \\
\hline $12 / 12$ & 0.00 & 0.00 & 0.00 & 0.00 & 0.00 & 0.00 & 0.00 & 0.00 & 0.00 & 0.00 & 0.00 & 346 \\
\hline $12 / 13$ & 0.00 & 0.00 & 0.00 & 0.00 & 0.00 & 0.00 & 0.00 & 0.00 & 0.00 & 0.00 & 0.00 & 347 \\
\hline $12 / 14$ & 0.00 & 0.00 & 0.00 & 0.00 & 0.00 & 0.00 & 0.00 & 0.00 & 0.00 & 0.00 & 0.00 & 348 \\
\hline $12 / 15$ & 0.03 & 0.03 & 0.00 & 0.00 & 2.54 & 0.00 & 0.05 & 0.08 & 0.00 & 0.00 & 0.00 & 349 \\
\hline $12 / 16$ & 0.00 & 0.03 & 1.22 & 1.73 & 0.00 & 0.38 & 0.48 & 0.71 & 0.53 & 0.00 & 0.13 & 350 \\
\hline $12 / 17$ & 0.00 & 0.00 & 0.63 & 0.76 & 0.00 & 0.30 & 0.43 & 0.43 & 1.37 & 0.79 & 1.80 & 351 \\
\hline $12 / 18$ & 0.00 & 0.00 & 1.73 & 2.31 & 7.62 & 3.43 & 0.51 & 0.05 & 2.87 & 5.16 & 6.30 & 352 \\
\hline $12 / 19$ & 0.03 & 0.00 & 0.15 & 0.25 & 0.00 & 0.03 & 0.08 & 0.03 & 1.70 & 0.53 & 0.03 & 353 \\
\hline $12 / 20$ & 0.00 & 0.00 & 3.43 & 4.37 & 0.00 & 0.00 & 0.00 & 0.00 & 2.21 & 2.79 & 0.08 & 354 \\
\hline $12 / 21$ & 0.00 & 0.00 & 0.66 & 1.12 & 0.00 & 0.20 & 0.10 & 0.08 & 5.87 & 8.26 & 1.24 & 355 \\
\hline $12 / 22$ & 0.46 & 0.51 & 1.50 & 1.60 & 2.54 & 1.24 & 0.38 & 0.10 & 2.39 & 8.36 & 6.53 & 356 \\
\hline $12 / 23$ & 0.33 & 0.46 & 0.03 & 0.08 & 0.00 & 0.00 & 0.05 & 0.00 & 4.60 & 0.25 & 1.91 & 357 \\
\hline
\end{tabular}




\begin{tabular}{|c|c|c|c|c|c|c|c|c|c|c|c|c|}
\hline $\begin{array}{l}\text { Date } \\
(2010)\end{array}$ & $\begin{array}{c}A Z \\
\text { C:05:0031 U }\end{array}$ & $\begin{array}{c}A Z \\
\text { C:05:0031 L }\end{array}$ & $\begin{array}{c}A Z \\
C: 13: 0365 \mathrm{U}\end{array}$ & $\begin{array}{c}A Z \\
C: 13: 0365 \mathrm{~L}\end{array}$ & $\begin{array}{c}A Z \\
C: 13: 0006\end{array}$ & $\begin{array}{c}A Z \\
C: 13: 0336 \mathrm{U}\end{array}$ & $\begin{array}{c}A Z \\
C: 13: 0346 \mathrm{U}\end{array}$ & $\begin{array}{c}A Z \\
\text { C:13:0346 L }\end{array}$ & $\begin{array}{c}A Z \\
B: 11: 0281\end{array}$ & $\begin{array}{c}A Z \\
A: 15: 0033\end{array}$ & $\begin{array}{c}A Z \\
G: 03: 0072 \mathrm{U}\end{array}$ & $\begin{array}{l}\text { Year } \\
\text { day }\end{array}$ \\
\hline $12 / 24$ & 0.00 & 0.00 & 0.00 & 0.00 & 0.00 & 0.00 & 0.00 & 0.00 & 0.00 & 0.00 & 0.00 & 358 \\
\hline $12 / 25$ & 0.00 & 0.00 & 0.00 & 0.00 & 0.00 & 0.00 & 0.00 & 0.00 & 0.00 & 0.00 & 0.00 & 359 \\
\hline $12 / 26$ & 0.00 & 0.00 & 0.03 & 0.00 & 0.00 & 0.00 & 0.00 & 0.00 & 0.08 & 0.00 & 0.00 & 360 \\
\hline $12 / 27$ & 0.00 & 0.00 & 0.00 & 0.00 & 0.00 & 0.00 & 0.00 & 0.00 & 0.00 & 0.00 & 0.00 & 361 \\
\hline $12 / 28$ & 0.00 & 0.00 & 0.00 & 0.00 & 0.00 & 0.00 & 0.00 & 0.00 & 0.00 & 0.00 & 0.00 & 362 \\
\hline $12 / 29$ & 3.02 & 3.30 & 6.07 & 7.90 & 7.62 & 4.57 & 4.83 & 1.65 & 17.32 & 9.45 & 3.58 & 363 \\
\hline $12 / 30$ & 0.25 & 0.99 & 0.81 & 2.08 & 2.54 & 2.21 & 3.00 & 0.00 & 0.91 & 0.33 & 0.36 & 364 \\
\hline $12 / 31$ & 0.00 & 0.00 & 0.00 & 0.00 & 0.00 & 0.00 & 0.00 & 0.00 & 0.00 & 0.00 & 0.00 & 365 \\
\hline Total & 275.9 & 369.2 & 354.8 & 421.3 & 360.1 & 325.8 & 308.1 & 233.0 & 421.8 & 357.4 & 294.2 & Total \\
\hline
\end{tabular}


Table 3. Vector sums of the sediment-transport proxy variable, $Q p$ (equation 1), by month for each weather station, 2010.

[Vector sums are reported as the magnitude of $Q p$, in cubic meters per cubic second, followed by the direction from which the net transport would occur, in degrees true. $A$, Vector sums were calculated using all available wind data, irrespective of rain events. $B$, Vector sums were calculated using only wind data from periods when sand was assumed to be dry enough to be transported. "N/A" indicates data were not collected.]

\begin{tabular}{|c|c|c|c|c|c|c|c|c|c|c|c|c|c|}
\hline $\begin{array}{c}\text { Station } \\
\text { name }\end{array}$ & Jan. & Feb. & Mar. & Apr. & May & June & July & Aug. & Sept. & Oct. & Nov. & Dec. & $\begin{array}{c}\text { Net } \\
\text { vector } \\
\text { sum } \\
\end{array}$ \\
\hline AZ C:05:0031 U & 680,146 & 442,210 & 9603, 231 & 41611, 245 & 43098, 246 & 14788,250 & 5266, 236 & 10539, 253 & 3969, 243 & 2059, 261 & 8672,248 & 10238, 246 & 149490, 245 \\
\hline AZ C:05:0031 L & 106, 81 & 251,217 & 2588,223 & 15679, 251 & 12425, 242 & 3621,249 & 329, 216 & 2695, 265 & 476, 220 & 142, 200 & 2537, 237 & 3547,258 & 43465,246 \\
\hline AZ C:13:0365 U & 24239, 350 & 5903, 145 & 140570, 151 & 315440,154 & 379410, 154 & 157920, 155 & 84859, 156 & 119260, 155 & 86783, 155 & 50073, 157 & 80613,156 & 103660, 156 & $\begin{array}{c}\text { 1500600 } \\
154\end{array}$ \\
\hline AZ C:13:0365 L & 1772, 325 & 1510, 327 & 3762,197 & 23165,170 & 22975, 166 & 5833,171 & 733, 80 & 5339, 171 & 3466,173 & 1350, 203 & 2953, 178 & 7504,167 & 72645,171 \\
\hline AZ C:13:0006 & 731, 166 & 434, 8 & 4992, 77 & 29688, 137 & 21001, 129 & 13226, 135 & 5965,135 & 8766,143 & 3691,125 & 4274,142 & 5961,124 & 5168, 121 & 100400, 131 \\
\hline AZ C:13:0336 U & 64633, 53 & 40206, 72 & 91313, 147 & 172260, 155 & 246740, 156 & 78005,161 & 38632, 164 & 38729, 161 & 32358,154 & 45096, 153 & 57464,147 & 111500, 149 & 907640,148 \\
\hline AZ C:13:0346 U & 9620, 204 & 21308, 221 & 80082, 220 & 95474, 224 & 114860, 232 & 36003, 229 & 14348, 215 & 15086, 223 & 17561, 226 & 2826, 225 & 31180, 222 & 64237, 230 & 500130, 225 \\
\hline AZ C:13:0346 L & 3265,228 & 22045, 238 & 98078, 232 & 146460, 237 & 201030, 238 & 60045,237 & 19017, 235 & 27572, 237 & 28636, 237 & N/A & N/A & N/A & 652360, 217 \\
\hline AZ B:11:0281 & 14347, 127 & 1475, 181 & 2427, 48 & 47717, 99 & 74332, 102 & 38586, 106 & 16000,109 & 38138,108 & 14881, 103 & 3872,112 & 9111, 94 & 3301, 95 & 257450,104 \\
\hline AZ A:15:0033 & 4559, 351 & 1179, 349 & 1393, 154 & 5835,189 & 6044,180 & 4170, 188 & 1266, 185 & 4152, 191 & N/A & 835, 315 & 727,270 & 806,268 & 16664, 185 \\
\hline AZ G:03:0072 U & 373,171 & 684, 111 & 10276, 189 & 18890, 198 & 25958, 197 & 18598, 200 & 15268, 205 & 17527, 203 & 12278, 202 & 3962, 191 & 4034, 192 & 1374,170 & 127970, 198 \\
\hline \multicolumn{14}{|l|}{$B$} \\
\hline $\begin{array}{c}\text { Station } \\
\text { name }\end{array}$ & Jan. & Feb. & Mar. & Apr. & May & June & July & Aug. & Sept. & Oct. & Nov. & Dec. & $\begin{array}{c}\text { Net } \\
\text { vector } \\
\text { sum } \\
\end{array}$ \\
\hline AZ C:05:0031 U & 74,117 & 123, 252 & 9640,233 & 30861,246 & 38407,247 & 13585, 252 & 3283, 242 & 3295, 255 & 1637, 237 & 1698, 278 & 4015, 244 & 1902, 247 & 107740, 246 \\
\hline AZ C:05:0031 L & 47, 104 & 16, 285 & 2827, 225 & 15521, 253 & 12977, 245 & 3477, 251 & 403, 227 & 396, 315 & 126, 146 & 133, 234 & 1708, 234 & 3685, 266 & 40270, 249 \\
\hline AZ C:13:0365 U & 4449, 352 & 1288,128 & 77615,147 & 227110,155 & 124690,154 & 142440, 155 & 39449, 157 & 17312, 156 & 31315, 154 & 24547, 156 & 48077, 155 & 2240,160 & 730990, 154 \\
\hline AZ C:13:0365 L & 1440,332 & 758,328 & 1907, 214 & 19245, 169 & 21073, 164 & 6019, 170 & 1252,177 & 345, 184 & 834, 173 & 975, 178 & 1280,180 & 167, 191 & 50596, 170 \\
\hline AZ C:13:0006 & 82, 204 & 341, 358 & 4047, 54 & 17810, 136 & 16725, 132 & 13124, 135 & 3950, 132 & 2924, 124 & 1656, 115 & 2467, 140 & 2200, 119 & 2164, 115 & 63431, 129 \\
\hline AZ C:13:0336 U & 56905,16 & 23546, 52 & 75161, 146 & 133050, 154 & 144320, 155 & 76459, 160 & 26151, 161 & 11837, 163 & 23689, 153 & 29649, 148 & 25822, 145 & 32985, 147 & 533990, 147 \\
\hline AZ C:13:0346 U & 1634, 68 & 10696, 223 & 61146, 223 & 58832, 229 & 88451, 233 & 27882, 229 & 7593, 218 & 2371, 211 & 11513, 227 & 35756, 228 & 12322, 222 & 15886, 228 & 330000, 228 \\
\hline AZ C:13:0346 L & 4492, 60 & 8777, 235 & 50211, 231 & 82586, 238 & 122090, 239 & 58129, 237 & 11567, 237 & 4585, 236 & 18423, 236 & N/A & N/A & N/A & 362210, 223 \\
\hline AZ B:11:0281 & 11462, 127 & 2767,153 & 5208, 95 & 42691, 101 & 65441, 102 & 38580, 107 & 11891, 109 & 17034, 108 & 8728, 103 & 1998, 108 & 4621, 101 & 461, 99 & 208770, 105 \\
\hline AZ A:15:0033 & 4212, 353 & 1259, 350 & 529, 148 & 5570, 190 & 6105, 181 & 4241, 188 & 1486, 182 & 610, 190 & N/A & 644,323 & 1044, 339 & 362, 282 & 11782, 194 \\
\hline AZ G:03:0072 U & 38,63 & 398, 188 & 9132, 189 & 18151, 200 & 23718, 199 & 18180, 200 & 12777, 204 & 7610, 203 & 8623, 202 & 2536, 201 & 2241, 194 & 267, 205 & 103370, 200 \\
\hline
\end{tabular}


This page left intentionally blank 
Publishing support provided by the U.S. Geological Survey

Publishing Network, Tacoma Publishing Service Center

For more information concerning the research in this report, contact the SBSC staff, Southwest Biological Science Center

U.S. Geological Survey

2255 N. Gemini Drive

Flagstaff, AZ 86001

http://sbsc.wr.usgs.gov/ 
क्ष

\&

言

흥

륳

홍

음

롫

을.

몰

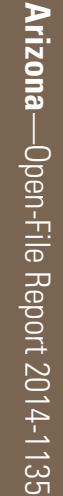

